$$
\begin{aligned}
& \text { (1) }
\end{aligned}
$$

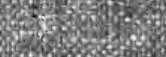

$$
\begin{aligned}
& \text { : }(2)
\end{aligned}
$$

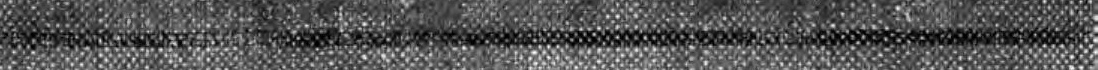

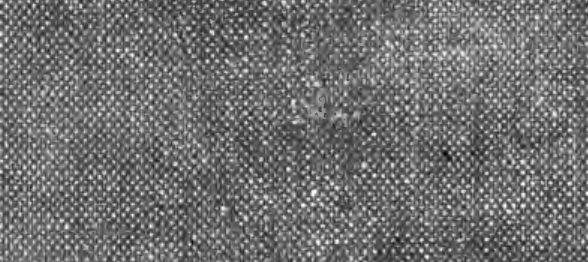

(\%)

\%

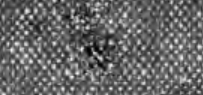

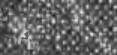

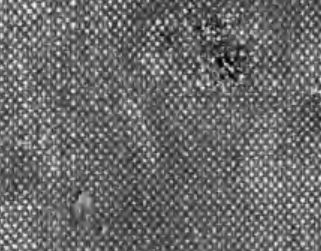

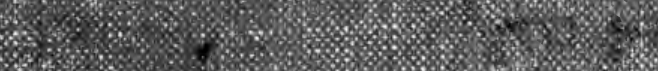

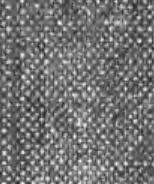

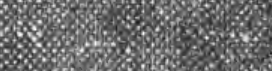

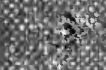

*6\%

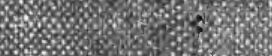

56

\begin{tabular}{c}
3 \\
\hline
\end{tabular}

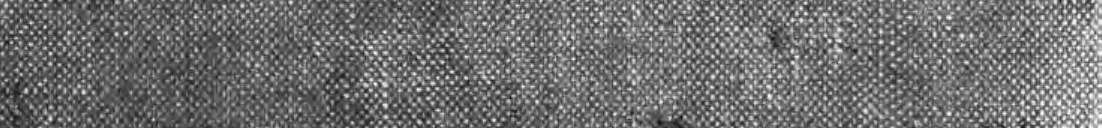

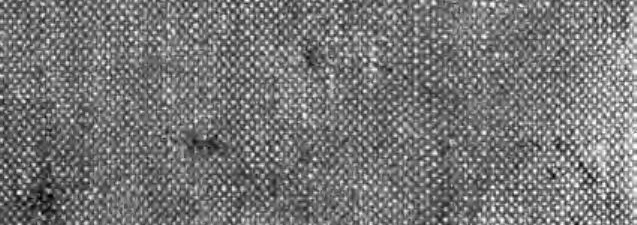

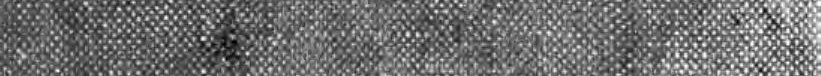

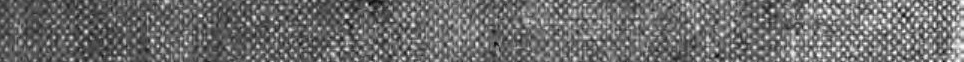




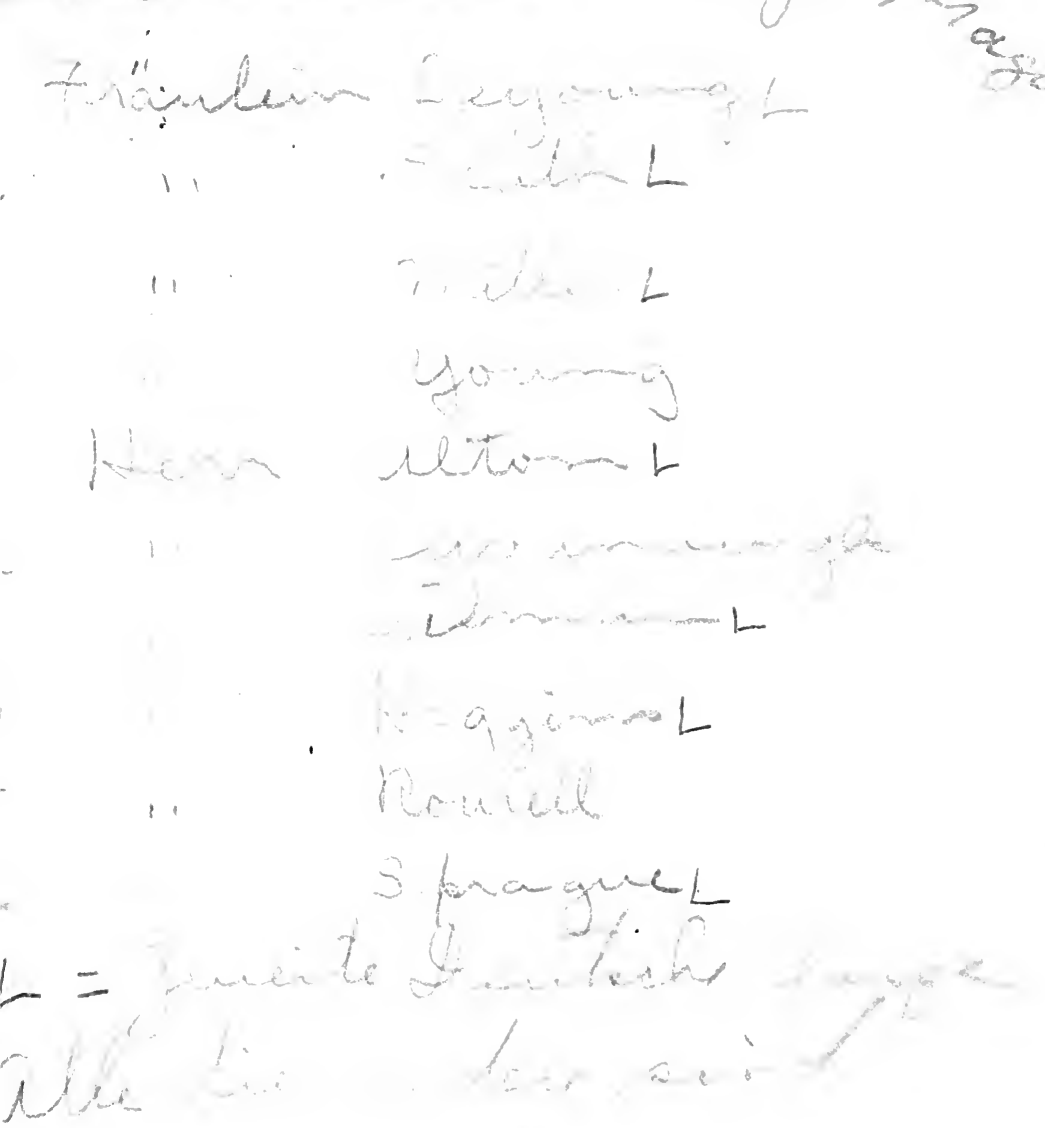


Digitized by the Internet Archive in 2010 


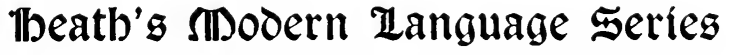

\author{
AN \\ ELEMENTARY GERMAN GRAMMAR
}

BY

E. C. WESSELHOEFT, A. M.

Professor of German, University of Pennsyluania

D. C. HEATH \& CO., PUBLishers

BOSTON NEW YORK CHICAGO 
COPYRIGHT, I9I2,

By D. C. Heath \& Co.

I $\mathrm{H} 2$ 


\section{PREFACE}

This book is written chiefly for the average beginner in high school or academy. By increasing the pace, it will be found entirely suitable for beginners in college. Whether pupils study a language with a view to reading it intelligently, or to speaking it, there are certain elements of grammar which it is imperative for them to know. Therefore the chief aim of the author has been to present the essentials of grammar as clearly and concisely as possible, and to offer abundant practice, both oral and written, on every lesson in grammar.

Those teachers who do not favor translating from English into German, or who wish to defer it until a class is well advanced, will find abundant drill-work in the Reading and Drill Exercises. The Written Exercises could then be used in reviewing the book. Care has been taken to base the sentences of the Written Exercises, as far as possible, on those of the Reading Exercises, so that the vocabulary, which, for a beginner, is as essential as the grammar, is repeated. The simple style of every-day speech has been preserved throughout the exercises; words of unusual occurrence have been intentionally avoided. Whenever the grammar to be illustrated permitted it, connected discourse has been introduced in the Reading Exercises. Some of the Exercises offer material for conversation as well as drill on grammar. Whether the so-called Drill Exercises should be used for oral or for written practice is left to the discretion of the teacher.

In the presentation of the grammar the verb has been assigned the most prominent place; nouns are treated briefly, only the most practical rules for their inflection having been 
given. Instead of presenting all the cases of the article in orre lesson, the author has thought it best to devote one lesson to each case, and to present article and pronoun together.

The accent and the quantity of the vowel, in the case of words frequently mispronounced, have been indicated in the lessons and in the vocabularies.

An Appendix has been added, containing paradigms and lists of strong and irregular verbs, auxiliaries of tense, and modal auxiliaries. The list of verbs governing the genitive and those governing the dative, likewise some practical rules for determining gender of nouns and word-formation, are also given.

Orthography is based on the last edition of Duden's Orthographisches Wörterbuch.

For many useful corrections and suggestions the author is indebted to Professor E. Z. Davis and Dr. A. Schumacher, both of the University of Pennsylvania, and to Mr. A. G. Host of the Troy High School, N. Y. For a careful revision of the whole book and practical criticisms he acknowledges his indebtedness to Mr. R. B. Marvin of the Commercial High School, Brooklyn.

\section{E. C. WESSELHOEFT.}

University of Pennsyluania, 1912. 


\section{CONTENTS}

PAGR

INTRODUCTION :

Alphabet . . . . . . . . . . . . . . . ix

Use of Capitals . . . . . . . . . . . . . $\mathrm{x}$

Division into Syllables . . . . . . . . . . . $\mathrm{x}$

Punctuation . . . . . . . . . . . . . . $\mathrm{x}$

Pronunciation . . . . . . . . . . . . . .

Accent . . . . . . . . . . . . . . . xvi

LESSONS

I. Present Indicative of jein. -- Pronouns of Address . . 1

II. Nominative of Definite Article and of Personal and Interrogative Pronouns. - Gender of Nouns. Agreement of Pronoun and Noun . . . . . . 3

III. Present Indicative of haben, lernen, arbeiten, heiß̄en . 6

IV. Nominative Plural of Definite Article and of Personal Pronouns. - Aceusative Forms . . . . . . . 9

V. Genitive of Definite Article, Nouns, and Interrogative Pronouns. - Proper Names . . . . . . . . 12

VI. Present Indicative of werben, geben, fehen, lejen . . . 15

VII. Dative of Definite Article, Nouns, Personal and Interrogative Pronouns. - Position of the Indirect Objeet

VIII. Past Tense of fein, haben, faufen, reben, arbeiten. - Formation of the Past Tense of Weak Verbs. - Position of nicht.

IX. Review of Deelension of Definite Article, Noun and Pronoun. - Compound Nouns

X. Perfect and Pluperfect Tenses. - Past Participle of Weak Verbs.-Uses of Perfect and Past Tenses. Position of Past Participle. - Position of Adverbs of Time

XI. Deelension of Pronominal Adjeetives (১er words) Rule for Gender of Nouns in $e$

XII. Deelension of Indefinite Artiele, of fein and Possesive Adjectives (ein words). - Agreement of Personal Pronouns and Possesive Adjeetives 
XIII. Future and Future Perfect. - Position of Infinitive. - Imperative . . . . . . . . . . 40

XIV. Review. - Paradigms of haben, fein, madfen. - Review Questions. - Rejeftücfe

$\mathrm{XV}$. Position of the Verb in Independent Clauses. Co-ordinate Conjunctions

XVI. Past and Perfect Indicative of geben, lejen, werden. - Principal Parts of Verbs. - Synopses of ge= ben, lejen, werden

XVII. Present Indicative of Strong Verbs. - Imperative. - Inseparable Verb-Prefixes.

XVIII. Use of haben and fein as Auxiliary Verbs. - Conjugation of Intransitive Verbs with jein . .

XIX. Separable Verb-Prefixes. - Conjugation of a Separable Verb. - Commonest Separable Verb-Prefixes. - Use of hin and her.

XX. Declension of Adjectives. - Strong Declension of Adjectives

XXI. Weak Declension of Adjectives. - Use and Declension of berjelbe

XXII. Mixed Declension of Adjectives. - Summary of Rules for the Declension of Adjectives . . .

XXIII. Adjectives used as Nouns. - “Gin Words" used as Adjectives or Nouns

XXIV. Comparison of Adjectives. - Use of alzz and wie after Adjectives or Adverbs. - Predicate Superlative.

XXV. Review of Lessons XV to XXIV. - Rejeitüde . $\quad 88$

XXVI. Declension of Nouns. - First Class Strong. Neuter Diminutives in dfen and lein . . .

XXVII. Second Class Strong of Noun Declension. - Genitive and Accusative of Time . . . . . . . $\quad$. 98

XXVIII. Third Class Strong of Noun Declension . . . 101

XXIX. Weak Declension of Nouns. - Rules of Gender . 104

XXX. Prepositions governing the Accusative. - Infinitive with $\mathfrak{u m}$... zu. - Irregularities of Noun Declension 
XXXI. Prepositions governing the Genitive and Dative. Nouns of measure, etc. and the Partitive Genitive

XXXII. Prepositions governing Dative or Aceusative. Use of an and auf. - Contraction of Prepositions with the Article

XXXIII. Position of the Verb in Compound Sentences. Subordinating Conjunctions and their Uses

XXXIV. Relative Pronouns and Relative Clauses. $-\mathfrak{W e r}$ and $\mathfrak{w a z}$ as Relative Pronouns. - Omission of Auxiliary Verb in Dependent Clauses

XXXV. Review of Lessons XXV to XXXIV. - Rejeititufe

XXXVI. Separable Verbs in Dependent Clauses. - Demonstrative Pronouns. - Conjugation of tun and wifien. - Uses of wifien and temen

XXXVII. Irregular Weak Verbs. - Present Participles. Verbs in ieren. - Omission of $\partial a \mathfrak{B}$

XXXVIII. Genitives of Personal Pronouns. - Reflexive Pronoun. - Reflexive Verbs . . . . . . . 145

XXXIX. Impersonal Verbs. - Idiomatic Uses of ez . . 151

XL. Passive Voice. - Uses of man and Reflexive Verb as Substitutes for Passive Voice

XLI. Subjunctive Mood. - Uses of the Subjunetive. Subjunctive of Indirect Discourse

XLII. Subjunetive Mood and its Uses (continued) . . 164

XLIII. Review of Lessons XXXV to XLII. - Eefeitüfe . 170

XLIV. The Modal Auxiliaries. - Conjugation of burrfen, fönten, mögen $\quad . \quad$. . . . . . . . . . . . 174

XLV. The Modal Auxiliaries (continued). - Conjugation of müfien, follen, wollen, lafien

XLVI. The Conditional Mood. - Variable Verb-Prefixes 184

XLVII. Cardinal Numbers. - Ordinal Numbers. - Expressions of Time and Date. - Names of Months and Days

XLVIII. Use of the Cases. - Summary of the Commonest Uses of Cases

XLIX. Review of Lessons XLIII to XLVIII. - Rejejtüde 


\section{APPENDIX}

A. Verb Paradigms:

I. Seaben, fein, werben $\quad . \quad$. . . . . . . . . . 209

II. Weak Conjugation . . . . . . . . . 212

III. Strong Conjugation . . . . . . . . . 214

IV. Conjugation with fein . . . . . . . . . . . 215

V. Passive Voice . . . . . . . . . . . . . . 216

VI. Inseparable and Separable Verb Compounds . 217

VII. Reflexive Verb . . . . . . . . . . 218

VIII. The Modal Auxiliaries . . . . . . . . 219

B. Strong Verbs arranged in Classes _ . . . . . . . 220

C. Alphabetical List of Strong and Irregular Verbs _ . . . . 224

D. List of Verbs governing the Genitive . . . . . . 229

E. List of Verbs governing the Dative . . . . . . . 230

F. Rules for the Determination of Gender of some German Nouns 230

G. Word Formation . . . . . . . . . . . . . 231

H. German Script . . . . . . . . . . . . . . 236

VocabUlaries . . . . . . . . . . . . . . . 239

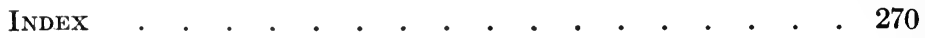




\section{ELEMENTARY GERMAN GRAMMAR}

\section{INTRODUCTION}

Alphabet. - The German alphabet, when printed in Roman letters, is the same as the English alphabet. When printed in German letters, the appearance is quite different.

\begin{tabular}{ccc|ccc}
$\begin{array}{c}\text { Roman } \\
\text { Form }\end{array}$ & $\begin{array}{c}\text { German } \\
\text { Form }\end{array}$ & $\begin{array}{c}\text { Pronun- } \\
\text { ciation }\end{array}$ & $\begin{array}{c}\text { Roman } \\
\text { Form }\end{array}$ & $\begin{array}{c}\text { German } \\
\text { Form }\end{array}$ & $\begin{array}{c}\text { Pronun- } \\
\text { ciation }\end{array}$
\end{tabular}
A $\quad$ a $\quad \mathfrak{H} \quad \mathfrak{n} \quad a /$
$\mathrm{B} \quad \mathrm{b} \quad \mathfrak{B} \quad \mathfrak{b} \quad b a y$
C c $\quad$ c $c$ tsay
$\mathrm{D} d \mathfrak{D}$ d day
$\mathrm{E} \quad \mathrm{e} \quad \mathfrak{5} \quad \mathfrak{c} a y$
$\mathrm{F}+\mathfrak{F} \mathfrak{i} \quad$ cff
$\mathrm{G} \quad \mathrm{g} \quad$ (G) $\mathfrak{g}$ gay
$\mathrm{N} \quad \mathrm{n} \quad \mathfrak{l} \quad \mathfrak{n} \quad c n n$

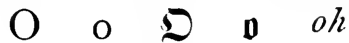
$\mathrm{P} \quad \mathrm{p} \quad \mathfrak{P} \quad \mathfrak{p}$ pay

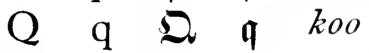

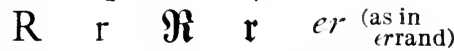
$\mathrm{S} S \mathfrak{j} \mathfrak{j}$ ess
$\mathrm{T} \mathbf{t} \mathfrak{t}$ tay

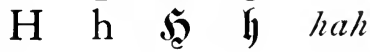
$\begin{array}{lllll}\mathrm{I} & \mathrm{i} & \mathfrak{J} & \mathrm{i} & c c\end{array}$
$\mathrm{J} \quad \mathrm{j} \quad \mathfrak{j}$ j $y o t$

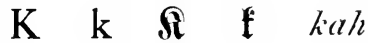
$\mathrm{L} \quad \mathfrak{Q} \mathbb{l}$ cll
$\mathrm{M} \mathrm{m} \mathfrak{M} \mathbb{\mathrm { l }} \mathrm{cmm}$
$\mathrm{U} \quad \mathrm{l} \quad \mathbb{l l} \quad \mathfrak{l} \quad$ oo
$\mathrm{V} \quad \mathrm{V} \quad \mathfrak{Z} \quad \mathfrak{v}$ fow ${ }_{\text {fowl }}$
$\mathrm{W} \quad \mathrm{W} \quad \mathfrak{B} \quad \mathfrak{w} \quad \tau^{\prime} a y$
$\begin{array}{lllll}\mathrm{X} & \mathrm{x} & \mathfrak{t} & \mathfrak{d} & i x\end{array}$
$\mathrm{Y} y$ Y) $\mathfrak{y}$ ipsilon
$\begin{array}{lllll}Z & z & 3 & j & t s c t\end{array}$

Note that $s$ has two forms ( $j$ and $z$ ). At the end of a word, at the end of a syllable in compounds, and before suffixes (except suffixes of inflection) $\mathfrak{s}$ is used, elsewhere $\mathfrak{j}$ : $\mathfrak{S} \mathfrak{a} \mathfrak{z}$,

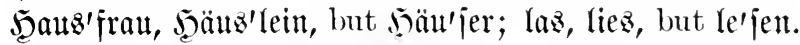

Certain letters, when joined to others, change their form slightly $; \mathfrak{d}=c h ; \mathfrak{f}=c k: \mathfrak{t}=t z ; \dot{z}=\mathfrak{j}$ and $\mathfrak{j}$, sounded like $s s$ 
in hiss and therefore more commonly represented by $s s$ than by $s \approx$ when Roman letters are used.

The combination $\tilde{z}$ is used at the end of a word or syllable and before $\mathrm{t}$; likewise after a long vowel or a diphthong: $\mathfrak{F} \bar{u} \tilde{\mathfrak{k}}$,

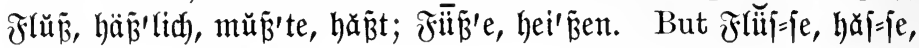
miif'jen.

Capitals. - 1. Every noun and every word so used begins with a capital, as: $\mathfrak{d a z} \mathfrak{B u d}$, the book; von meinem $\mathfrak{B a t e r}$, from my father; in Deutidland, in Germany; bas Gute, the good; bas sejen, the reading; etwas dieuez, something new.

2. The pronoun Sie, you, and its possessive $\mathfrak{F} \mathfrak{h}$, your, are written with capitals; likewise all their case-forms. $\mathfrak{D} u$, thou, and its possessive bein, are written with capitals only in letters. Other pronouns take a small initial.

3. Unlike English usage, adjectives derived from names of

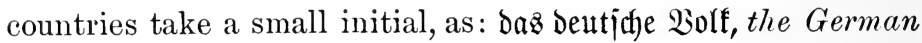
people.

4. Adjectives in $\mathfrak{c r}$ from names of towns begin with a capital, as: Berliner Zeitungen, Berlin newspapers.

Division into Syllables is indicated at the end of a line by a double hyphen $(\Leftrightarrow)$.

1. A single consonant between two vowels belongs to the second vowel: $\mathfrak{b} \mathfrak{a}^{\prime}=\mathfrak{d e n}, \mathfrak{l a \mathfrak { u }} \mathfrak{u}^{\prime}=\mathfrak{F e n}, \mathfrak{M} \mathfrak{a}^{\prime}=$ ler.

2. The consonant combinations, $\mathfrak{d}$ ), $\mathfrak{p h}, \mathfrak{j} \mathfrak{d}), \mathfrak{i t}, \tilde{\mathfrak{B}}$ and th) (which really represent simple sounds) between two vowels, belong to

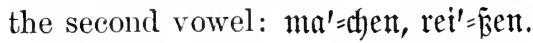

3. Other consonant combinations are separated, the last consonant belonging to the second vowel: $\mathfrak{B a} \mathfrak{j}^{\prime}=\left\{\mathfrak{e r}, \Re \mathfrak{a} \mathfrak{t}^{\prime}=\mathfrak{z e}\right.$, jin's'=gen, $\mathfrak{2} \mathfrak{p p}^{\prime}=$ fel.

4. Compounds are divided according to composition: $\mathfrak{A}\left(\mathfrak{p}^{\prime} \mathfrak{f} \mathfrak{l}=\right.$ baum, $\mathfrak{w e g}^{\prime}=$ gehen, $b \mathfrak{a}=$ bon' .

Punctuation. - The marks of punctuation are used, in general, 
as in English, but the comma occurs more frequently, as it is always employed to set off subordinate clauses. The hyphen $\Leftrightarrow$ is not used in ordinary compounds; thus $\mathfrak{G a}$ astiir, streetdoor. It is used, however, to take the place of an omitted

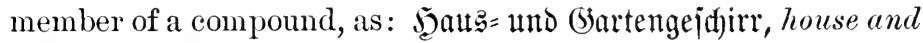
garden utensils.

Quotation-marks are placed thus: „if fomme," jagte er, "I a m coming," said he.

German Script. - German has its own script, which is still used, but may also be written with the Roman script (English writing). For German seript see Appendix.

Pronunciation. - German spelling, on the whole, is far more phonetic than English spelling. There are no silent letters in real German words, excepting as follows:

(1) $\mathfrak{h}$, when medial or final, is used to indicate that the preceding vowel is long: $\mathfrak{D h r}$, befép'len.

(2) Long $\boldsymbol{i}$ is often written $\mathfrak{i}$; in which case the $\mathfrak{e}$ is silent: ou liejt, Melodie'.

Otherwise every letter must be pronounced: $\mathfrak{i n} \bar{a}^{\prime} \mathfrak{b e}, \Re^{\prime} \bar{o}^{\prime} \mathfrak{j e}$, lè'’je.

Vowels. - As in English, the vowels are: $\mathfrak{a}, \mathfrak{c}, \mathfrak{i}, \mathfrak{n}, \mathfrak{a}$. Avoid pronouncing simple long vowels as if diphthongs. English vowels are quite commonly pronounced as if diphthongs. A double vowel, or a vowel followed by $\mathfrak{h}$, is long: $\mathfrak{B} \bar{e} \bar{e} t, \mathfrak{b} \bar{a} \bar{a} \mathfrak{r}$, Etūhll, gèht, ihm.

An accented rowel at the end of a syllable, or a vowel that is followed by a single consonant, is generally long; if followed by two consonants, it is usually short; thus the vowel is long

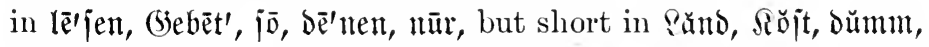
jŏd'len, wěj'jen. In some of the monosyllables, however, even

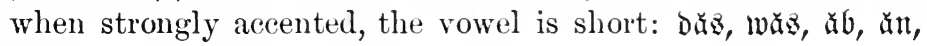
$\mathfrak{h i n , ~ u ̆ m . ~}$ 
A long stem vowel remains long in inflections, even when several consonants forming the inflection follow: $\mathfrak{b} \bar{a} t \tilde{t} \mathrm{t}, \mathfrak{M} \mathbf{i} \overline{\mathrm{u}} \mathrm{t}$, (from bāt, $\mathfrak{M} \bar{u} \bar{t})$.

Before $\mathfrak{d}$ and $\tilde{\mathbf{z}}$ a vowel may be either long or short: $\mathfrak{B} \bar{u} \mathfrak{h})$, $\mathfrak{M} \overline{\mathfrak{a}} \tilde{\mathfrak{B}}$, but $\mathfrak{B} a \mathfrak{c} \mathfrak{h}, \mathfrak{J} \mathfrak{a} \tilde{\mathfrak{B}}$.

$\mathfrak{A}, \mathfrak{a}$, generally speaking, has only one sound (viz., like English $a$ in 'father'), and this may be either long or short.

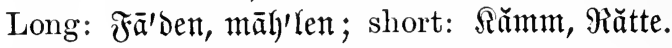

$(\mathfrak{F}, \mathfrak{e}$ long has approximately the sound of English $a$ in 'mate': gểht, Mēēer; e short like $e$ in 'met': fětt, ẹ̌'iên. Unaccented $e$ is slurred. Thus in words ending in $\mathfrak{e n}$, the $\mathfrak{e n}$ is pronounced like en in 'frighten': ‘ei'ten, b'e'ten. Words ending in unaccented $e$ are very common in German, and this $e$ is pronounced like the English $a$ in

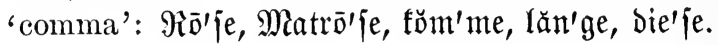

$\mathfrak{\$}, \mathfrak{i}$ long has the sound of $i$ in 'machine': $\mathfrak{i n m}, \mathfrak{i} \mathfrak{h}^{\prime} \mathfrak{n}$ en. Short $\mathfrak{i}$

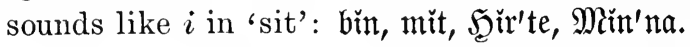

Se, ie is pronounced like long $i$ : Sieb, Melodie', riejt; but in a few words not of German origin these two letters are

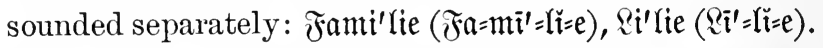

$\mathfrak{D}, \mathfrak{v}$ long has approximately the sound of $o$ in 'note': $\{\overline{\mathfrak{o}}, \mathfrak{\Re} \overline{\mathfrak{o}} \mathfrak{h} \mathfrak{r}$; o short is pronounced somewhat like the $o$ in 'forty', but shorter: fŏm'men, fŏrt, (S)ŏtt, tŏll.

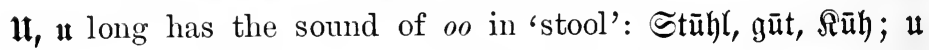
short, like $u$ in 'pull': Miŭtter, $\breve{u} \mathfrak{m}, \mathfrak{B u ̆ t t e r}$.

Modified Vowels. - The term modified vowel, or umlaut (change of sound), is used to designate a peculiar change of the vowel sounds $\mathfrak{a}, \mathfrak{o}, \mathfrak{H}$, and the diphthong $\mathfrak{a}$, which is indi-

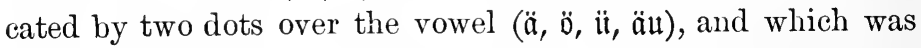
due originally to the influence of an $i$ or $j$ in the following syllable; the effect of this $i$ or $j$ was to make the preceding vowel more like $i$. In the older spelling $\ddot{\mathfrak{A}}, \mathfrak{\mathfrak { D }}, \ddot{\mathfrak{U}}$ and $\mathfrak{Y} \mathfrak{u}$ were 
written $\mathfrak{A} e, \mathfrak{D}$, lle, $\mathfrak{P} \mathfrak{u}$; but, in writing, this script $\mathfrak{e}$ was often placed above the letter, and eventually came to resemble two dots. These were in time adopted to indicate umlaut.

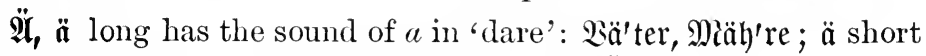
is like $e$ in 'bet': $\mathfrak{S} \ddot{a} \mathfrak{n}$ 'be, bän'be, $\mathfrak{2} \mathfrak{l}$ 'te.

$\mathfrak{D}, \ddot{\mathfrak{j}}$ has no exact equivalent in English. To produce the sound of long $\ddot{b}$, round the lips as for $o$ in 'pole' and pronounce the ay of 'day': $\mathfrak{g} o \mathfrak{b}$ 'le, bö'je. To produce the sound of short $\ddot{b}$, round the lips slightly and pronounce short $e$, as in 'let': öfî́'nen, fön'nen.

$\ddot{\mathfrak{i}}$, $\mathfrak{i}$ also has no exact equivalent in English. To produce the sound of long ii, round the lips as for oo in 'woo' and then pronounce long $e$ as in 'he': $\mathfrak{i t}$ 'ber, rii'gent. Short ii has the same sound, requiring however less rounding of the lips: miij'jen, Friij'je.

$\ddot{\mathfrak{A}}_{\mathfrak{u}}, \ddot{\mathfrak{a}} \mathfrak{u}$ has the sound of $o i$ in 'oil', and is always long: $\mathfrak{S} \ddot{a} \mathfrak{u} \mathfrak{t}^{\prime} \mathfrak{e r}$, Bäı'me, räu'men.

Note. - The modified rowels are never doubled. Substantives with a double vowel are written with only one vowel when modified by

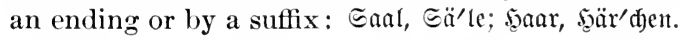

Diphthongs. $-\mathfrak{A} \mathfrak{i}, \mathfrak{a} \mathbf{i}$ and $\mathfrak{c i}$ have the sound of $i$ in 'fine':

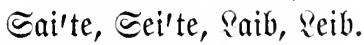

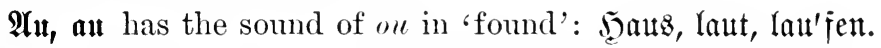

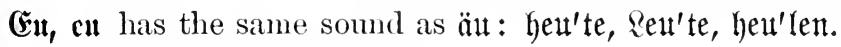

All diphthongs are long.

Consonants. - The following consonants differ in sound from the English equivalents:

$\mathfrak{B}, \mathfrak{b}$, at the end of a word or syllable, and before an inflectional suffix beginning with a consonant, has the sound

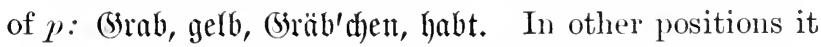
is pronounced like English $b: \mathfrak{B r a} \mathfrak{a}^{\prime} \mathfrak{n}, \mathfrak{b} \mathfrak{n t}$, blei'ben. 
$\boldsymbol{C}, \mathfrak{c}$ occurs only in words of foreign origin. It has the sound of $k$ before the vowels $\mathfrak{a}, \mathfrak{o}, \mathfrak{u}, \mathfrak{a} \mathfrak{u}, \mathfrak{o u}$ or a consonant: (Eaje', Cato, Clique; otherwise like $t s$ (Cäjar), or $z$ (Eylinder).

$(\mathfrak{C} \mathfrak{h}, \mathfrak{d}$, after $\mathfrak{a}, \mathfrak{b}, \mathfrak{u}$, or $\mathfrak{a} \mathfrak{u}$, has a guttural sound for which there is no equivalent in English. It may be formed by

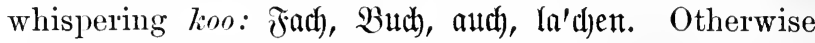
it has a higher palatal sound: idd), bidh), Bii'cher, Dä'cher, reidy, rie'd)en.

NoTE. - In pronouncing, idf, bidf, midf, etc. correctly, press the tip of the tongue firmly against the lower teeth. A void pronouncing di like a $k$.

If $\mathfrak{d})$ is followed by an or $\{$ belonging to the same syllable

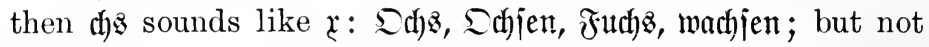
in wad)' $\mathfrak{j a m}$, since the $\{$ belongs to another syllable.

In foreign words $\mathfrak{d}$ ) often has the sound of $k$ : (Charaf'ter.

$\mathfrak{D}, \mathfrak{D}$, at the end of a word or syllable, and before an inflectional suffix beginning with a consonant, has the sound

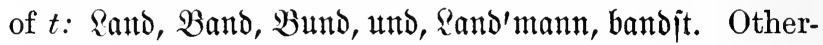
wise like $d$ : Pän'ber, $\mathfrak{B a ̈ n} \mathfrak{n}^{\prime} \mathbf{b e r}$, ba, banden.

ot has the sound of $t$ : ๔tabt, gefandt.

$\mathfrak{G}, \mathfrak{b}$, at the end of a word or syllable, and before an inflectional suffix beginning with a consonant, has the guttural sound of $\mathfrak{d}$ ), as in $\mathfrak{T} \overline{\mathfrak{a}} \mathfrak{g}, \mathfrak{l o} \mathfrak{g}, \mathfrak{l} \bar{a} \mathfrak{g} \mid$ t. It has the palatal sound of $\mathfrak{c h}$ in words like $\Re \ddot{o}^{\prime} \mathfrak{n i g}, \mathfrak{\Re a ̈ ' f i g}$, liegit, and in this position therefore is subject to the same rules of pronunciation as $\mathfrak{d}$ ). In other positions $\mathfrak{g}$ has the sound of $g$ in

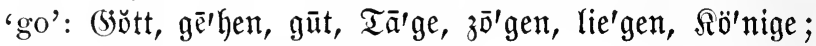
likewise when doubled: Flăg'ge.

Note. - In some parts of Germany the final $\mathfrak{g}$ is sounded like $\mathfrak{t}$, in others like $\mathfrak{g}$. There is great diversity of usage.

$\mathfrak{s}, \mathfrak{h}$, at the beginning of a word or syllable, has the sound of $h$ in 'hat': Şaus, $\mathfrak{T} a \mathfrak{u s}$ 'herr, hö'ren, hod). Following a vowel in the same syllable, it is silent and indicates 


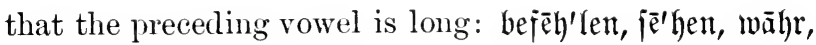
[âa $\mathfrak{l}$.

$\mathfrak{I}_{1} \mathrm{i}$ has the sound of $y$ in 'yes' or 'yonder': $j \overline{\mathfrak{a}}, \mathrm{j} \overline{\mathrm{e}}, \mathrm{j} \overline{\mathrm{e}}$ ' $\mathrm{der}$.

$\mathfrak{L}, \mathfrak{l}$ has the sound of $l$ in 'long' and is never silent: $\mathfrak{h a l} \mathfrak{i}, \mathfrak{b} \mathfrak{b} \mathfrak{l b}$.

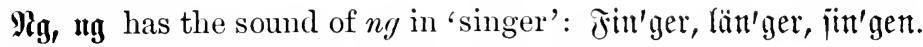

Avoid giving it the sound of $n g$ in 'finger'. In compounds, when belonging to different component parts, $\mathfrak{n}$ and $\mathfrak{g}$ are pronounced separately: $\mathfrak{a} \mathfrak{n}^{\prime}=\mathfrak{g e h} \mathfrak{h}$, Eint $=\mathfrak{g a n g}$.

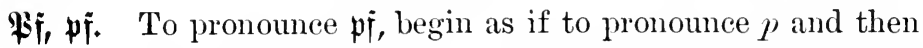

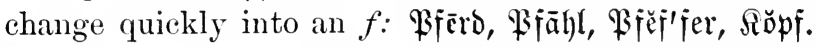

$\mathfrak{l} \mathfrak{n}, \mathfrak{q} \mathfrak{t}$ has the sound of $k v$ with the lips somewhat less

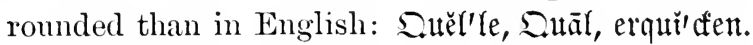

$\mathfrak{i}, \mathfrak{r}$ is pronounced more distinctly and with more of a trill or roll than in English: ról'len, Fei'ter, but'ter, hart.

$\mathcal{S}_{,} \mathfrak{i}, \mathfrak{B}$, at the beginning of a word before a vowel, or between two vowels, has the sound of $\approx$ in 'zine': $\bar{j} \overline{0}, \overline{j a}$ 'gen, lép'jen. When final, doubled, or standing before a consonant not at the beginning of a word, $z$ or $j$ has the sound of $s$ in 'so': waz, wěj'jen, löj'te.

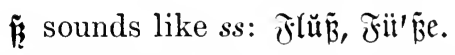

Eq, ip, and $\boldsymbol{E}_{t}$, it, at the begimning of a word, have the sound of shp and sht: Emrā'dhe, iparn'nen, Stein, jtē'hen; likewise in compounds: ver=\{prěs'chen, ber=jtet'hen. Otherwise they have the sound of $s p$ and st: $\mathfrak{B}$ es'pe, niejt.

Edd, fdy has the sound of sh in 'ship': f(d) netll, raut'idhen.

$\mathfrak{T}, \mathbf{t}$ has the sound of $t$ in 'tin': Tier, Tiir, mit ; but, in words of foreign origin before $i$, it gets the sound of $t s$ or $\approx$ : Mation', Portion'.

$\mathfrak{T} \mathfrak{h}$, $\mathfrak{t h}$ was formerly used in words of German origin and can still be found in many books, thum for tūn, rōth for rōt, etc. Modern German uses th exclusively for words of foreign origin. It has the sound of $t$ : Thea'ter, Thron. 


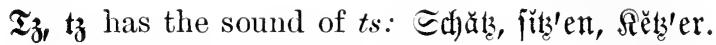

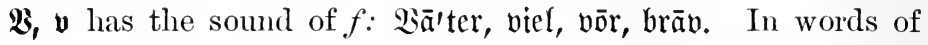
foreign origin, except when final (as in brab)', $\mathfrak{v}$ sounds

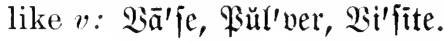

$\mathfrak{B}, \mathfrak{w}$ has the sound of $v$ at the beginning of a word or syllable: Măá'fer, wěl'cher, 'ö'me, Miö'me. After a consonant, usually 3 or $\{\mathfrak{d}$ ), it has a sound somewhat between $v$

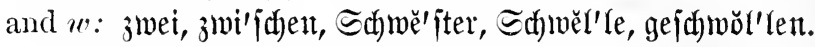

Note. - To produce $\mathfrak{w}$ after $f \mathfrak{d}$ ) or $z$ form the lips as if in the act of blowing.

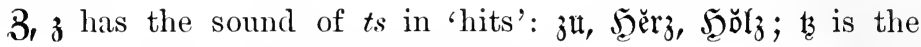
written form of $3 j$ : jižen, fetzen.

Accent. - Simple German words have the chief stress or accent on the root syllable: $\mathfrak{B} \bar{a}^{\prime}$ ter, lie'ben, $\Re o^{\prime} \mathfrak{n i g}, \Re \ddot{o ̈}^{\prime} \mathfrak{n i g t u m}$, Frei'beit. Verbs in ie'ren are exceptions: telephonte'ren, ftu= bie'ren; likewise nouns in ei: Bäaferei', ̊ionditorei'.

Compounded words generally follow the same rule; the stem of the first member of the compound having the primary accent, and the stem of the second member a secondary accent: Sint'bergar'ten, Frau'enlie'be.

Compound particles generally accent the second member: hinab', barauf', bahin'.

The following prefixes are never accented: be, ent, er, ge, ber, zer.

The prefix $\mathfrak{u n}$ is generally accented: $\mathfrak{u n}^{\prime} \mathfrak{g e r n}, \mathfrak{u n} \mathfrak{n}^{\prime} \mathfrak{w i f l} i \mathfrak{g}$.

Words from the French or Latin are generally accented on the last syllable: Majif', Student', Miegiment'. 


\section{LESSON I}

1. Present Indicative of the verb jeill, to be.

SiNgULAR

1st. pers. idf b̆it, I am.

2nd. pers. Dā bijt, thou art, you are. 3rd. pers. $\left\{\begin{array}{l}\bar{e} r \text { îjt, he is. } \\ \text { fie } \mathrm{ijht,} \mathrm{she} \mathrm{is.} \\ \text { ês } \mathrm{ijt} \text { it it is. }\end{array}\right.$
Plcral

1st. pers. wir jünd, we are. ?nd. pers. ihr jeid, you are. 3rd. pers. fie fint, they are. 2nd. pers. Sie jünd, you are (sing. and pl.).

In questions: bin idy, am $I$ ? bijt bu, art thou? ift $\mathrm{cr}$, is he? etc.

(1) The third person of the verb is used with nouns, as in English :

Sarl ijt hier, Charles is here.

Sarl uno Miărie' fund hier, Charles and Mary are here.

(2) bu (thou, you) and its plural (ifr) are used in familiar address, when speaking to relatives, children, or friends who would be addressed in English by their first names, likewise in solemn address (as in prayer or poetry); otherwise Gie (written with a capital) is used. Thus:

Sarl, bijt bu hicr? Charles, are you here?

Siarl unb Mărie', jeto ifhr hier? Charles and Mary, are you here?

Eind Sic hier, berr Mieier? Are you here, Mr. Meier?

Eind Eie hier, Sgerr und Frau Mieier? Are you here, Mr. and Mrs. Meier?

a. Notice that, like the English you, Eie is used in addressing either one or several persons. 
VOCABULARY

\$ěrr, Mr., gentleman, master.

Sărl, Charles.

Seinridy, Henry.

Frau, Mrs., woman, wife.

Mlăric', Mary.

wwărแt, warm.

fălt, cold.

wōlyl, well, in good health.

frănf́, sick, ill.

gĕ $\mathfrak{x} \overline{\mathfrak{u} g}$, enough.

găı̊ quite.

brau'

ăfle, all. $\mathfrak{w} \overline{\mathbf{o}}$, where.

wie, how.

bã, there.

hier, here.

jā, yes; ucin, no.

aud $\mathfrak{d}$, also.

nuxd, not.

jēfor, very.

āber, but.

ŭndo, and.

băn't'te, thank you.

zin, too.

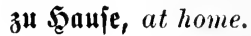

\section{READING EXERCISE}

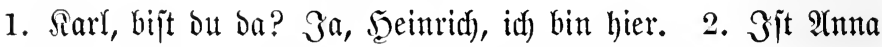
ba? Sa, fie ijt aud hier. 3. Wo ijt Marie? Sie ijt nidbt hier. 4. Sit Dtto da? Yein, er ijt auth nidft hier. 5. Seib ihr ba, Sarl und ?(nna? $\mathfrak{T}$, und es ijt warm genttg, ez ijt nicht falt hier

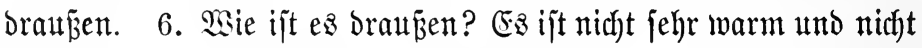
jehr falt. 7. Da jind Şerr und Frau Meier. 8. Sind Sie ganz wohl, Seer Meier? $\mathfrak{a}$, banfe, idh bin ganz wohl, aber Marie und Dtto jind franf; jie jind zu Şauje. 9. હind Sie hier alle wohl? 3a, banfe, wir jind afle ganz wohl. 10. Wo jind Sarl und $\mathfrak{A} \mathfrak{n}$ na? Eie jind braupen. 11. Sijt ez nicht ju falt brausen? Kein, es ijt

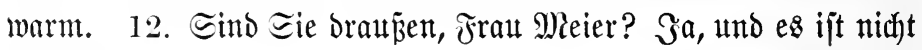
falt ljier.

\section{DRILL}

Note. - It is suggested to the teacher that much rapid oral drill be given in the Grammar of this, and each succeeding lesson.

Questions could be rapidly put such as: German for "she is" - 
"it is" — "they are" - "are you?" (three ways). English for "Eint Sie"? "ijt er"? "jeib ihr"? etc. The drill given in each lesson should not be regarded as anything more than suggestive and limited.

A. Conjugate: idh bin wohl; bin id nidht franf?

B. Answer the following questions in German: 1. Wo ijt Sarl? 2. Sit ?(nna aud) da? 3. Sind Siurl und ?tuna warm genug? 4. Wie ijt ez braupen? 5. Git Şerr Mieier mohl? 6. Eind Marie und Stto wohl? 7. Wo jutb Marie und Dtto? 8. Sit es falt braujen? 9. Sit ez marm genug?

\section{WRITTEN EXERCISE}

1. Where is Charles, Anna? He is not here; he is ill. 2. Are you well, Anna? Yes, thank you, I am well. 3. She is here, but Charles is not here; he is not well. 4. Charles is at home. 5. It is cold outside but warm at home. 6. Mary and Otto are at home; they are not well. 7 . Are you well, Mrs. Meier? Yes, thank you, but Mr. Meier is ill. 8. It is warm enough here, and it is warm outside. 9. Are you there, Mary and Otto? Yes, we are here, and it is too warm.

\section{LESSON II}

\section{Nominative Case, Singular.}

Definite Article. Personal Pronoln. Interrogidtive Pronoun. Masc. ber Mann, the man. $\quad \overline{\mathrm{e}} \mathrm{r}$, he. Fem. Dic Fraul, the woman. jie, she. Neut. Dảs $\mathfrak{B} \overline{\mathfrak{n}}$, , the book.

(1) As in English, the nominative case is used rhiefly as the subject of a verb, or as the predicate of jein (to be).

3. Gender. - Like English, German has three genders: masculine, feminine, and neuter. For these three genders 
the definite article has three distinct forms in the nominative case as given above.

(1) Nouns which are masculine in English are masculine in German; nouns which are feminine, with but very few exceptions, are feminine; but nouns, neuter in English, may be masculine, feminine, or neuter in German. Hence, in learning a noun which would be neuter in English, the article should be carefully learned with it, as:

$$
\begin{aligned}
& \text { ber Etŏf, the stick; Die Fëber, the feather or pen; } \\
& \text { bัa } \mathfrak{B} \overline{\mathfrak{u}} \mathfrak{d}) \text {, the book. }
\end{aligned}
$$

(2) The pronoun must agree with the grammatical gender of the noun to which it refers, e.g.:

Sio ijt bcr Etoct? Where is the stick? (Er ijt Gier, it is here. Sio iit bie Feber? Where is the pen? Sic ijt hier, it is here.

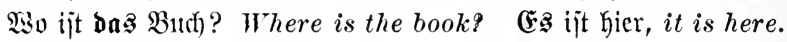

(3) Before nouns of different genders the article must be repeated, as:

Fer Mann uno die Fran find Gier, the man and woman are here.

4. Every German noun begins with a capital.

\section{VOCABULARY}

bcr Etorf, the stick.

ber Bleijtijt, the pencil.

bie Fidocr, the feather, pen.

bie Sircibc, the chalk.

die $\mathfrak{B a ̆ u f}$, the bench.

bie Tājol, the blackboard, slate

bas $\mathfrak{P}$ ăpier', the paper.

Das $\mathfrak{S c c h t t , ~ t h e ~ c o p y - b o o k . ~}$

ing $\mathfrak{P}$ itlth, the desk.

lăng, long. fŭrz, short. Ditf, thick. Dünt, thin. gīit, good. (d) lěĕdt, $b a d$. brault, brown. weik̂, white.

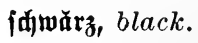
cin, one; zwei, two. orci, three; vicr, four. 


\section{READING EXERCISE}

1. Seier ijt ber Bleijtift, aber er ijt ju furj. 2. Wo ijt bie Jeber, Sarl? Die Feber ift hier, aber jie ijt ju biff. 3. Rein,

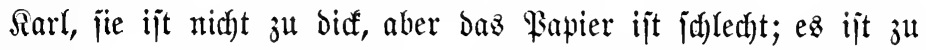
biinn. 4. Der Bleijtift, die Feder und bas Papier jind alle hier. 5. Da ijt baz Seeft; ez ijt biinn. 6. Seier ijt baz $\mathfrak{B u h}$, aber ez ijt jut bicf. 7. Da ijt bie Banf; jie ijt braun. 8. Wie ijt bas $\mathfrak{B u l t}$ ? (Es ijt aud) braun. 9. Das Pult und bie $\mathfrak{B a n f}$

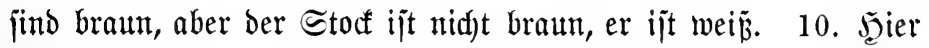

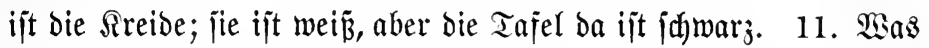
ijt Das (that)? Daz ijt bie Banf. 12. Wo ijt Der Mann? Er ijt nicht hier. 13. Sit bie Frau hier? Piein, fie ijt ju Seauje. 14. Der Mann ijt ந̌err Mieier, uno bie Frau ijt Frau Meier.

\section{DRILL}

A. Answer in complete sentences, using the pronoun: 1. Wo ijt der Bleijtift? 2. Wie ijt ber Breijtift? 3. Wie ijt bie Jeber? 4. Wie ijt das Papier? 5. Jit bas Sejt bict? 6. 3it bas $\mathfrak{B u d}$ ju bitnn? 7. Wie ijt bie Bant? 8. Jit ber Stodf lang? 9. Jit bie Sireibe weiń? 10. Wie ijt bie Tafel? 11. Sît ber Mann ju Şauje? 12. Wer ijt bie Frau?

B. Give the article with the following nouns: Breijtift,

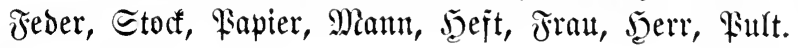

\section{WRITTEN EXERCISE}

1. Is the pencil white? No, it is black. 2. Where is the chalk? It is here. 3. There is the blackboard; it is black. 4. Is the copy-book thick? No, it is thin, but the book is thick. 5. Is the paper black or brown? No, it is white. 6. The paper and the pen are here, but the paper is too thick 
and the pen too thin. 7 . The pen is bad; it is too thick. 8. Where is the desk? It is here. 9. Is the bench long enough? Yes, it is long enough, but the desk is too short. 10. Who are you? I am Mr. Meier. 11. Who is the woman? She is Mrs. Meier. 12. The man and woman are Mr. and Mrs. Meier.

\section{LESSON III}

5. Present Indicative of $\mathfrak{h} \mathfrak{a}^{\prime} \mathfrak{b e n}$, to hare ; $\mathfrak{Y e r}^{\prime} \mathbf{n e w}$, to learn;

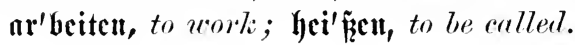

ìd hăăbe, I have.

id) lěrutc, I learn, am learning, do learn. Dü hăit, thou hast, you have. Dü lěrnit, thou learnest, you learn, etc. $\overline{\mathfrak{e}} \mathfrak{r} \mathfrak{l} \mathfrak{a} \mathrm{t}$, he has. fie hăt, she has. és lyăt, it has. $\overline{\mathfrak{e}} \mathfrak{r}$ lěrnt, he learns. jie lěrnt, she learns. wir hāâben, we have. čs lěrnt, it learns. îhr $\mathfrak{h}$ ăbot, you have. fie hăâben, they have. Eic hāaben, you have. wir lĕrnen, we learr. ihr lĕrnt, you learn. fie lĕrnen, they learn. Sic lĕrnen, you learn.

idf ar'beite, I work, am working, do work. bü ar'bciteit, thou workest, you work. $\overline{\mathfrak{e}} \mathbf{r}$, fie, $\mathfrak{e} \mathfrak{s} \mathfrak{a r b e i t c t , ~ h e , ~ s h e , ~ i t ~ w o r k s . ~}$ witr $\mathfrak{a r}$ 'beiten, we work. ihjer $\mathfrak{a r}$ 'beitet, you work. fie $\mathfrak{a r} / \mathfrak{b e i t e n}$, they work. Eic ar'beiten, you work.

idd heifzec, I am called. bī heif $[\mathbf{e}[\mathbf{i}]$, thou art called. $\overline{\mathfrak{e}} \mathfrak{r} \mathfrak{h e i} \tilde{z}_{2} \mathrm{t}$, he is called. wirr heifzen, we are called, ihr heif fie heingent, they are called. Eie heifzen, you are called.

(1) Notice that in $\mathfrak{h a b e n}$, Yernen, arbeiten, $\mathfrak{h} e i \tilde{\beta} e \mathfrak{n}, \mathfrak{h a b}-$, Icrn-, arbeit-, yein- are the stems, and -col is the ending of the infinitive. To the stem are added the personal endings $\mathbf{e}, \mathbf{i t}, \mathbf{t}$, $\mathfrak{c} \|, \mathfrak{t}, \mathfrak{c}$; $\mathfrak{h a b e n ~ h o w e v e r ~ i s ~ i r r e g u l a r ~ i n ~ t h e ~ s i n g u l a r , ~ i n a s m u c h ~}$ as it drops the $\mathfrak{b}$ in the second and third persons singular. 
(2) Most German verbs are conjugated like lermen in the present tense of the indieative, thus:

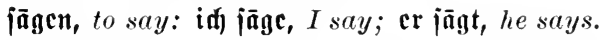

(3) Some verbs (see arkeiten) require an c before the personal endings of the second and third persons singular and the second person plural, whenever the it and $t$ are not easily pronounced with the preceding letters of the stem. Some (see heif́n) are frequently written with an $\mathfrak{c}$ in the second person singular, though generally pronounced like the third person.

6. Interrogation. - A sentence is made interrogative by placing the subject after the verb: Yernen Eie Deutid)? are you learning German?

(1) German has only the form idf rernc, for the three English forms: 'I learn', 'I am learning', 'I do learn'.

7. Negation. - A sentence is made negative by adding nidjt to it.

Qcrut Rarl nidgt? Does Charles not learn?

Rarl ipiclt nid)t, Charles is not playing.

\section{VOCABULARY}

ber $\mathfrak{B a}$ äter, the father.

ber Brintocr, the brother.

ber Qehrer, the teacher.

dic Ed)wẹ̌ter, the sister.

bas (bčldo, the money.

Dcutifi), German.

fāgen, to say.

braudjen, to need.

mux̆djen, to do, make.

ipicleu, to play.

wic hcipecit bu? what is your name? iđ heifzc, my name is.

ficięigig, diligent, diligently.

filcipigiger, more diligent.

jüng, young.

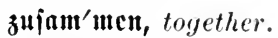

wărŭm', whhy.

vicl, much.

mchr, more.

mchr als, more than.

๓ŏd, yet.

mŏd) nid)t, not yet.

fō, so. 


\section{READING EXERCISE}

1. Wie heis[ej]t bu? Эa) heipe Sarl. 2. Was madjit bu? Эd) lerne Deutid). 3. Rernt Stto Deutid)? Rein, er lernt nod) nidyt Deutid); er ift zu jung. 4. Was madht Dtto? Er

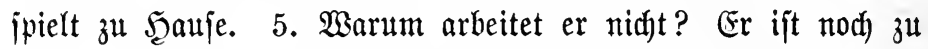
jung. 6. Die Schmejter lernt audh Deutjd; jie ijt jehr fleip̧ig. 7. Emma und idh haben Deutfa zulammen; jie lernt aber mehr als idy; jie ijt fleiß̧iger und fpielt nidht fo viel. 8. Wie

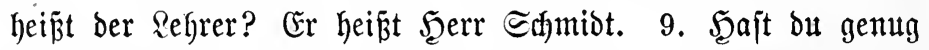

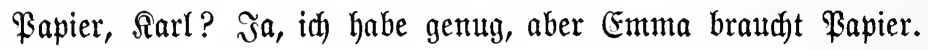

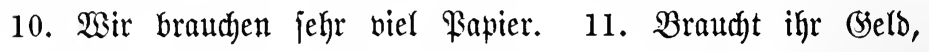
Sarl uno Emma? Rein, wir braudben es nicht; Bater hat

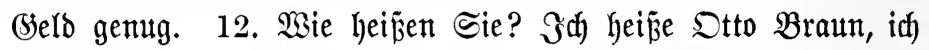

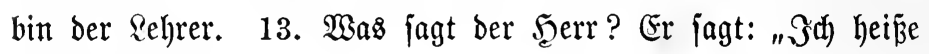
Dtto Brautn."

\section{DRILL}

The questions in the Reading Exercises can be used with the class for conversational purposes, if desired.

Conjugate: idf) habe Papier gemug; idf lerme Deutidh; ar= beite idh nidht fleisig? wie heize idh? id) fpiele zu Şaule; brauthe id (selo? id bin jung; was mache idy? mas jage idf?

\section{WRITTEN EXERCISE}

1. What are Charles and Emma doing (What make Charles and Emma)? Charles is playing, and Emma is working. 2. The sister is learning German; she is very diligent. 3. Otto does not learn (learns not) German; he is too young. 4. He is playing outside. 5. The brother and the sister need paper. 6. Otto does not need paper. 7. They have paper at home, but not here. 8. We have not enough paper here. 9. What does Otto say? He says: "I am not working, I am playing." 
10. Emma and Charles say: "We are working very diligently." 11. What is the name of the teacher? His name is Mr. Smith. 12. What are you (Sie) doing, Mr. Brown? I am learning German.

${ }^{1}$ German adverbs have the same form as the corresponding adjectives; hence fleifig means diligently, as well as diligent.

\section{LESSON IV}

\section{Nominative Case, Plural.}

\section{Definite ARticle}

Masc. bie Brüber, the brothers.

Fem. bie Ediweitern, the sisters.

Neut. bie Büdder, the books.

Personal Pronodn

fie, they.

(1) Notice that the nominative plural of the definite article is alike for all genders. The plural has no distinction of gender in any of its cases.

$a$. The rules for the formation of the plural of German nouns will be given later. In the meantime the beginner should learn the plural, as he learns the nouns, by heart.

\section{Accusative Case.}

The direct object stands in German (as in English) in the accusative ('objective') case. The accusative case answers the question wen? (whom?), or was? (what?), thus:

Sarl liebt ben Bāter, Charles loves the (his) father.

$\mathfrak{W e n}$ liebt $\mathfrak{A a r l}$ ? Whom does Charles love? Den Bater, the father.

Rarl hat ben Stŏf, Charles has the stick.

$\mathfrak{W} \mathfrak{a} \mathfrak{z}$ hat $\mathfrak{R a r l}$ ? What has Charles? $\mathfrak{D} \mathfrak{e n}$ Stoct, the stick.

Der Bater braud)t bna Beld, the father needs the money.

$\mathfrak{B} \mathfrak{a} \mathbb{B}$ braudft ber $\mathfrak{B a t e r}$ ? what does the father need? $\mathfrak{D} \mathfrak{a} \mathfrak{B}$ beld, the money. 


\section{Nominative}

IIasc. sing. $\left\{\begin{array}{l}\text { bcr } \mathfrak{B a ̄ t e r}, \text { the futher. } \\ \overline{\mathfrak{c} r}, \text { he. } \\ \text { wēer, who? }\end{array}\right.$

Fem. sing. $\quad\left\{\begin{array}{l}\text { sie } \text { Mutter, the mother. } \\ \text { fie, she. }\end{array}\right.$

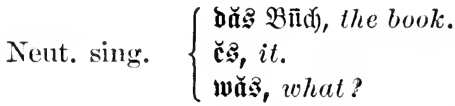

Plural for all genders

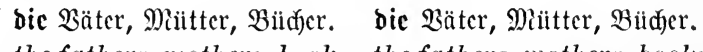
$\{$ the fathers, mothers, books. the fathers, mothers, books. jic, they.

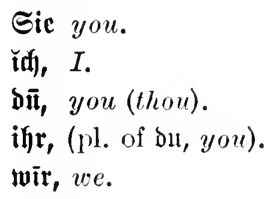
jic, them.
Sic, you. mutu, me. bidf, you, (thee).

cuch, you.

unts, us.
Accusative

ben $\mathfrak{B a ̄ t c r , ~ t h e ~ f a t h e r . ~}$ iljn, him.

wèn, whom?

bic Mutter, the mother. fic, her.

băs Būt, the book.

čs, it.

wăs, what?

a. In the feminine and neuter singular, and in all plurals, the nominative and the accusative are alike. This is true of articles, pronouns, adjectives, and nouns.

\section{VOCABULARY}

bcr Brici, the letter. bic $B \mathbf{r i c}^{\prime} \mathfrak{f e}$, the letters. bas Rind, the child. bie $\Re \mathrm{in}^{\prime} \mathrm{bcr}$, the children. bic Blciftiftc, the pencils. bic Febcrn, the pens. bcibe, both. gut, good, well. ant'wortcin, to answer. faufen, to buy. fenten, to know. fommen, to come. Iichelt, to love. lōben, to praise. rījen, to call.

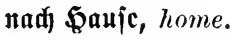

\section{READING EXERCISE}

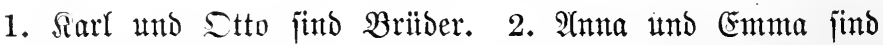
bic હânejtern. 3. Die Sinber fomment tad Şauje, und bie 
Mutter ruft: "Wer hat ben Brief?" 4. Stto jagt: „Siarl hat ihn." 5. Waz hat Siarl? Gr hat Den Briej. 6. Wien liebt Sarl? Er Yiebt ben Sater und die Mintter; er liebt jie beibe. 7. Der Bater unb bie Miutter lieben ifn audd). 8. Sarl brautd)t baz $\mathfrak{B u d}$; er faujt ez und aud Febern und Bleijtifte. 9. Ter Bater ruft: "Sinder, feib ifyr jut Jeauje?" 10. Tie Simber ant=

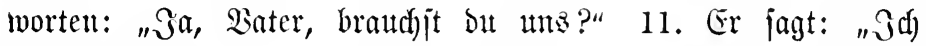

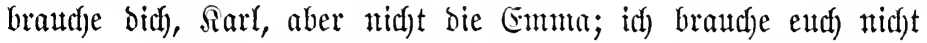
beibe." 12. ந̌err Braun fommt unb jagt: "গiennen Eie mid'), Seerr Meier?" 13. Ter Bater antwortet: "Ja, Serr Braum, idf) fenne Sie felgr gltt." 14. Sarl ijt jelgr fleiphig, uno Seerr Braun Yobt ifn. 15. S(nna ijt audh) fleip̧ig, unb er lobt jie auth).

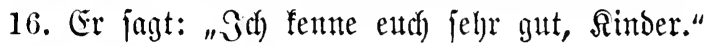

\section{DRILL}

A. Supply the omitted article:

1. Sd babe - Brier. 2. Sie hat - Breiftift. 3. Dat hajt — Feber. 4. Er liebt — Matter. 5. Die Matter liebt — Simb. 6. Ter Sater fauft — Sudd). 7. Er

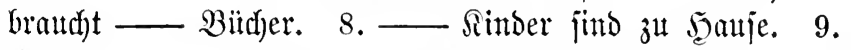
Sater lobt - Sittber. 10. Sarl untb Stto lieben — Water und — Matter. 11. _ Selyrer lobt— Bratber and Edhwejter. 12. \$ier hat — Etod? — Bater hat Etorf.

13. Conjugate: id rufe ben Bruber; id liebe bie Mutter;

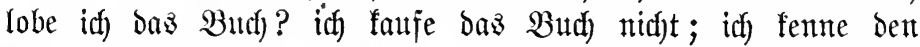
Miann; idh fomme nad) Samje; antworte idf? id braudje das

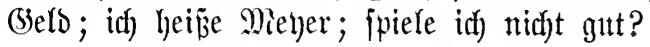

C. Give the accusative of: Der Briej, bie Brieje; bas Sint, bie Sinder; bie Feber, bie Febern; ber Bleijtift, bie $\mathfrak{B l e i j t i f t e ; ~ D i e ~}$ Bauf; baz Fapier. 


\section{WRITTEN EXERCISE}

1. Anna, have you the letter? Yes, mother, I have it. 2. Do you need it? No, Anna. 3. Charles, have you the pencils? Yes, I have them. 4. Who is calling me? I am calling you; I need you. 5. The father needs the brother but not the sister. 6. He does not need them both. 7. The mother praises the children; she loves them, and the children love the mother. 8. They love the father also. 9. Do you know the father? No, but I know the mother very well. 10. Charles, where is Anna? I need her. 11. She is not at home; she is buying pens and pencils, books and paper; she needs them. 12. Do you know her? No, I do not know her, but I know the brother and the sister very well. 13. Anna comes home and says: "Here are the books." 14. "Thank you, Anna," says the mother.

\section{LESSON V}

\section{Genitive Case.}

\section{Singolar}

Masc. Dèß $\mathfrak{B a ̄ t e r ß , ~ o f ~ t h e ~ f a t h e r , ~ t h e ~ f a t h e r ' s . ~}$

Fem. Der $\mathfrak{P u t t e r}$, of the mother, the mother's.

Neut. Dĕs Rin๖e马, of the child, the child's.

\section{Plural}

Masc. Der Bäter, of the fathers, the fathers'.

Fem. Der $\mathfrak{M}$ ütter, of the mothers, the mothers'.

Neut. Der $\Re$ inder, of the children, the children's.

Rarls, Charles's. Marieß, Mary's. weîen, whose.

Notice that the German genitive has no apostrophe, but that the English possessive requires it. 
(1) The genitive case represents the English possessive and most of the relations of two substantives to each other which are expressed in English by the preposition ' $o f$ ', as:

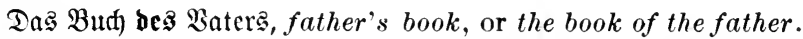

The genitive answers the question mejien? uhose?

(2) Most masculine, and all neuter nouns take $\mathfrak{s}$ or $\mathfrak{c}$ in the genitive singular (nouns of one syllable generally take $\mathfrak{e}$, others $\mathbf{3})$, thus:

Tå Şaus des Miannes, the man's house.

Iag Iach bes byaules, the roof of the house.

Der Brief Des Baters, father's letter.

(3) Feminine nouns remain unchanged in all cases of the singular: bas Bud ber Frau, the woman's book, or the book of the woman.

(4) The genitive plural of all nouns is like the nominative and accusative plural, as: bie $\mathfrak{B}$ iid)er Der Sinder, the books of the children, or the children's books.

Note. - In the vocabularies the plural of the nouns will be indicated by the following signs: -, means that the plural is the same as the singular: S(f)nciber, -, (pl., Sdnncioer); ", means that the stem-vowel receives an Umlaut, but no additional endings: Bruber, $"$, (pl., Brüber);

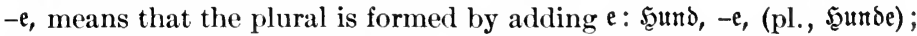
${ }^{e} \mathrm{e}$, means that the stem vowel receives an Umlaut and the ending $e$ : \&uft, "e, (pl., \&üfte); "er, means the addition of er and Umlaut: $\mathfrak{g a u s}$,

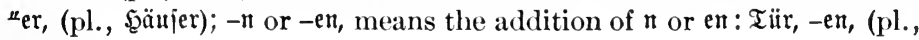
Iüren).

(5) Proper names (as in English), whether masculine or feminine, take $\mathfrak{s}$ in the genitive, thus: Şeinrid) $\mathfrak{B} \mathfrak{W}$ ), Henry's book; Mariez $\mathfrak{B r u b e r}$, Mary's brother.

(6) Proper names may be preceded by the definite article, as: $\mathfrak{W}$ o ijt ber Seinrid)? Where is (our) Henry? 
a. If the proper name is preceded by the article in the genitive case it remains uninflected, as :

Er ijt Der Bruber Der Maric, he is Mary's brother.

Eie ijt bie Edfwejter bes Scinrich), she is Henry's sister.

\section{VOCABULARY}

bic 2 unft, "e, the air.

bie $\mathfrak{T} i \mathrm{ir},-\mathfrak{e n}$, the door.

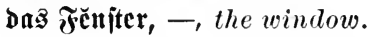

Das Bimmer, 一, the room.

Dng $\mathfrak{B} u l t,-\mathfrak{e}$, the desk.

frāgen, to ask.

liegen, to lie. $\mathfrak{g} \mathfrak{r} \overline{0} \tilde{z}$, large, great. $\mathfrak{a l s}$, as, than.

größ̨̧⿻上丨 als, larger than.

fïnf, five.

¡edis, six.

$\mathfrak{a} \boldsymbol{u}$, open.

ju, to, shut, closed.

\section{READING EXERCISE}

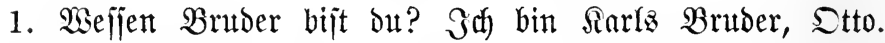

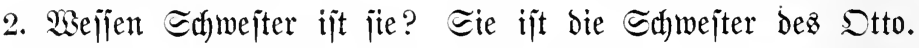
3. Sarl hat Dttoz $\mathfrak{B u d}$, und Dtto hat Mariez $\mathfrak{B u d}$. 4. 2ater fragt: "Weifen $B u d y$ liegt ba?" Sarl antwortet: "Ez ijt bas Buth) Der Miutter." 5. Mutter jagt aber (however): "Yein, ez

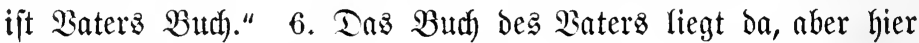
ijt Daz $\mathfrak{B u t h}$ Der Mutter. 7. Die Büdyer Der Sinder liegen hier. 8. Daz Zimmer ber Simber hat brei Fenjter und zmei Tiiren. 9. Die Fenjter dez Zimmerz jino auf, aber bie Tïren jint ju. 10. Tie Suft brauken ijt falt, aber bie Suft des Zim= mers ijt warm. 11. Tie Sinder haben zwei ßulte. 12. Daz

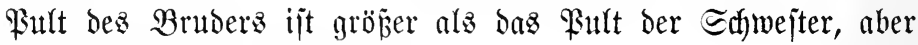
beibe Pulte jind groß́ gemutg.

\section{DRILL}

A. Supply the article: 1. Das $\mathfrak{B u d}$ - Raters. 2. Der Brief —-Mutter. 3. Die Büdher — Sinder. 4. Die 
3immer — Scaujes. 5. Die Tïr Z Zimmers. 6. Ter Bleiftift —- Sarl. 7. Das Pult Miarie. 8. Ter ভtod Brubers. 9. Die Feber — Edjuejter.

B. Conjugate: idh bin ber Bruber bes Sarl; id fenne den Bater ber Simoer; idf brauthe Das Bud ber Edymejter.

Note. - It is suggested that the pupils be asked such questions as:

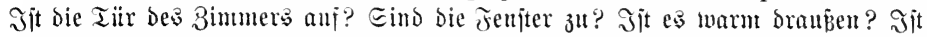

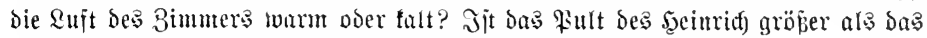

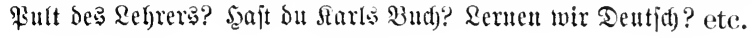

\section{WRITTEN EXERCISE}

1. Have you mother's book" Yes, and I have father's book also. 2. Whose pencil have you? I have Marie's pencil. 3 . The books of the children are not here; they are at home. 4. Henry's book is lying there 5. Henry is the brother of Mary. 6. The room of the children has five windows and three doors. 7. The doors of the room are open, but the windows are shut. 8. The air of the room is good, the doors are open. 9. Anna's desk is larger than Charles'; it is too large. 10. The desks of the children are large enough. 11. The desk of the sister is shut. 12. Whose desk is that (Das)? It is the desk of the teacher; it is open.

\section{LESSON VI}

11. werben, to become; geben, to give; jeflen, to see; lejen, to read.

\section{Presext Texse}

id) wërbe, I become, I am becoming. ou wirit, thou becomest, you become.

er, fie, es wird, he, she, it becomes. wir wōrben, we become.

ihr wërdet, you become. fic wërben, they become. Sic wērocn, you become. 


\section{Present Tense (continued)}

id) gēbe, I give, I am giving. bu gibit, ${ }^{1}$ thou givest, you give. er gibt, ${ }^{1}$ he gives. fic (ca) gibt, she (it) gives.

id fiche, I see, I am seeing. bu fiefit, thou seeest, you see. er fieft, he sees.

fie (e⿱⺈) jieht, she (it) sees.

idf lēje, I read, I am reading. bu lieft, thou readest, you read. er liejt, he reads. fie (e⿱彐⿰冫⿰亅⿱丿丶丶) licit, she (it) reads. wir gē $\mathrm{e}$ ent, we give. ifhr gēebt, you give. fie gēben, they give. Sie gēécn, you give.

wir jēhen, we see. ihyr iēt, you see. fie fēhen, they see. Sie jēhen, you see.

wir lējelt, we read. ihr lējt, you read. fie lépen, they read. Sie lējêt, you read.

${ }^{1}$ Pronounced either long or short and formerly written giebit, gieft.

(1) Some verbs (as above) change the $\mathfrak{e}$ of the stem into $\mathbf{i}$ or ie in the second and third persons singular of the present tense.

(2) $\mathfrak{B e r b e n}$ is irregular in the second and third persons singular, omitting the $\boldsymbol{b}$ in the second person and $\mathbf{t}$ in the third person.

(3) Notice that the second and third persons singular of lejen are alike (cf. heip̈en, $\S 5$ ).

\section{VOCABULARY}

Der Frei'tāg, -e, Friday.

Då $\mathfrak{B}$ Better, the weather.

Deutið'lănd (ঠa:), Germany.

hören, to hear.

interejiant', interesting.

ălt, old.

älter, older. ¡̊̆wēr, difficult, hard. englijđ), English. auj englifa), in English. auf beutid, in German. alle $\mathfrak{T} \overline{\mathfrak{a} g e, ~ e v e r y ~ d a y . ~}$ óft, often. bămit', with it. 


\section{READING EXERCISE}

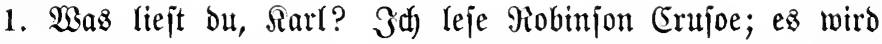
jehr interefijant. 2. Bater gibt bas (beld, und idh) faufe Bü̈der

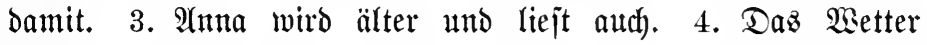
wirb warm, und wir lejen jehr biel brauken. 5. Wir lejen baz Bud zujammen. 6. Siehjt bu bie 9 (nna ojt? $\mathfrak{a}$, idh jehe jie alle Tage. 7. Rejt ihr Deutid) ober Englifh? Wir lejen ben

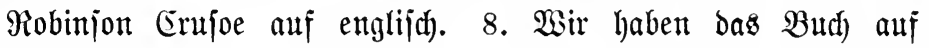

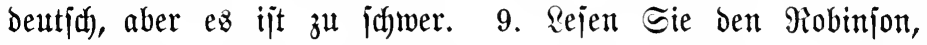
Seerr Braun? Piein, aber id fente baz Bud febr gut. 10. Ro= binjon jieht ben Freitag, aber Freitag jieht ihn nidht. 11. (Fr ruft ben Freitag; Freitag hört ihn nidat, aber er jieht ihn und fommt. 12. Robinjon arbeitet, und Jreitag wirb audh fleip̧ig, und jie arbeiten zujammen.

\section{DRILL}

A. Conjugate: merbe id nidht alt? gebe idh (seld? idh jehe ben Mann nid)t; leje idf bas $\mathfrak{B}$ ud)?

B. Give the genitive and accusative singular of: ber Mann, bie Frau, baz $\mathfrak{B u d}$, ber Stod, bie Bant, baz Papier, ber Blei=

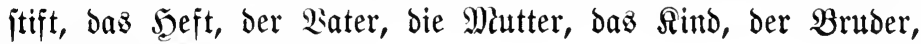
die Sabejter, daz Beld.

\section{WRITTEN EXERCISE}

1. Charles is reading Robinson Crusoe, but Anna is not reading it; it is too difficult. 2 . The book becomes very interesting. 3. The weather is becoming cold, and the children do not read outside; they read in the house (im $\mathfrak{5} \mathfrak{a} \mathfrak{u}$ e). 4. Charles sees Anna every day. 5. Mr. Brown does not read the book, but he knows it very well. 6 . The children have the book in German and in English. 7. The father gives the 
money, and the children buy the books. 8. Does Robinson see Friday? Yes, he sees him. 9. All children read the book. 10. Do children read the book in Germany? Yes, they read it in Germany in German. 11. The book is becoming very old; but it is so interesting! $\mathbf{1 2}$. We love the book, and we read it.

\section{LESSON VII}

\section{Dative Case.}

For the indirect object, which is usually expressed in English by ' $t o$ ' or ' $f \circ r$ ', there is in German a special case, the dative. It answers the question wem? (to or for whom?), as:

In gefe bem Bater ben Brief, I give the father the letter.

Baēm gebe id' Den Brief? Deu Siater, to whom do I give the letter?

To the father.

Die Mutter fauft bem ßinde Das Buth, the mother buys the book for the child.

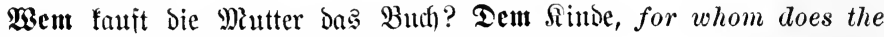
mother buy the book? For the child.

SingdLar

Dat. (bem $\mathfrak{B a t e r}$, to or for the father. ben $\mathfrak{B a ̈ t e r n}$, to or for the fathers. Dat.
Masc. $\left\{\begin{array}{l}\mathfrak{i} \mathfrak{h} \mathfrak{m}, \text { to him, for him. } \\ \mathbf{w e} \mathfrak{m}, \text { to whom. for whom. }\end{array}\right.$

Dat. (ber Mutter, to or for the mother. Fem. (ing, to her, for her.

Dat. (bem $\Omega$ inde, to or for the child. Neut. (ihm, to it, for it.

mitr, to me, for me. bir, to you, for you. ifhnen, to or for them. wề, to whom, for whom.

ben Müttern, to or for the mothers.

iffucu, to or for them.

Den $\Omega$ indern, to or for the children.

iffuen, to or for them.

utı, to us, for us.

eud, to you, for you.

Jhnen (dat. of 巨ie), to you, for you. (sing. and pl.). 
Er gibt mir ben Brief, he gives me the letter, or he gives the letter to me.

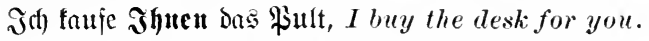

Eie bringt ifr bas Geld, she brings her the money, or she brings the money to (for) her.

(1) Masculine and neuter nouns of one syllable add $\mathfrak{c}$ (though it may be omitted) in the dative singular, thus: Dem Mann(e), to the man; Dem Iind(e), to the child; but Dem $\mathfrak{B a t e r}$ (two syllables), to the father.

(2) The dative plural of all nouns ends in $\mathbb{n}$, thus: bie Sinder, the children; Den Sindern, to the children. If the nominative plural ends in $\mathfrak{n}$ all the cases of the plural are alike, as: die Frauen, the uomen; Den Frauen, to the women.

(3) The indirect object precedes the direct object, unless the latter is a pronoun :

Jn gebe bem Manne bas $\mathfrak{B u d}$, I give the man the book.

But, $\mathfrak{J} \mathfrak{g}$ gebe $\mathfrak{c}$ bem Miaute, I give it to the man.

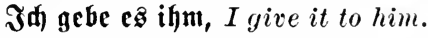

$a$. Notice that the construction is the same in English as in German; but, when a preposition is used, the indirect object follows in English: 'I give the book to the man'.

\section{VOCABULARY}

ber ⿶ōhn, " $\mathrm{e}$, the son.

ber Sdinei'ber, -, the tailor.

ber $\Xi_{\mathfrak{d}} u \mathfrak{h},-\mathfrak{c}$, the shoe.

Der Etrŭmuf, " $\mathfrak{e}$, the stocking.

ber Mŏft, " $\mathrm{e}$, the coat.

Dic Tŏdter, *, the daughter.

bns Slcid, -er, the dress.
$\mathfrak{D a \mathfrak { B }} \mathfrak{T} \overline{\mathfrak{u}} \mathfrak{d}, "$ "er, the cloth.

zeigelt, to show.

bringen, to bring.

tlein, small.

alles, everything.

Dnfiir', for it, for them.

nidts, nothing.

\section{READING EXERCISE}

1. Das Wetter wirb falt, und ber sater fauft dem Sohne ভdjuhe und Strümpje. 2. Er jeigt ber Mutter bie ভduthe, 
und jie jagt: "Die Schuhe jind ihm nidht groß genug." 3. Die Mutter gibt bem @ohne bie Strïmpfe. 4. Der @dneiber mad)t bem 2 ater zwei Röcfe. 5. Die Rödfe jint ihm nicht

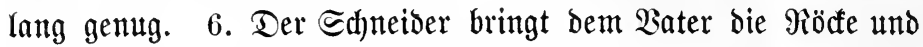
fragt: "Sind bie Miöfe Jhnen lang genug?" 7. Der Bater gibt

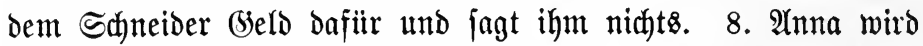

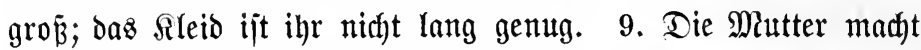
ber Todbter brei Rleiber; ber Bater fauft ihr bas Tuth. 10. Bater und Mutter geben ben Rindern Sdjuke und Strïmpfe,

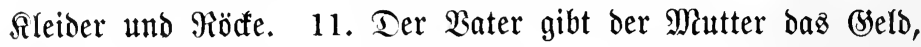
uno bie Mutter fauft ihnen alles. 12. Die Mutter jagt: "Sinder, idh faufe eud Sleiber; Der $\mathfrak{B a t e r}$ gibt mir Beld.“

Questions. - (Answer in full sentences). 1. Wem fauft ber Bater (d)uhe? 2. Wem jeigt er bie (d)uhe? 3. Was jagt bie Mutter? 4. Wem gibt bie Mutter die Striimpfe? 5. Waz madyt ber Saneider bem Bater? 6. Wem fino bie Röde nidht lang genug? 7. Waz gibt Der Bater bem @dneider? 8. Wem mad)t bie Mutter brei ßleider? 9. Wem fauft ber $\mathfrak{B a t e r}$ baz Tuth? 10. Was faufen $\mathfrak{B a t e r}$ und Mutter ben Sindern? 11. Wem gibt ber $\mathfrak{B a t e r}$ daz Belo? 12. Was jagt bie Mutter ben Sindern?

\section{DRILL}

A. Conjugate: id gebe bem Sdneider (Seld; idh zeige ber Mutter baz Sleid; idh bringe bem Bater bie @(huhe.

B. Supply the omitted article: 1. Der Mann gibt Sinde daz Budf. 2. Fr gibt_- Fraut bas Gielb. 3. Die Mutter gibt_L Bater ben Briē. 4. Er tauft — Sindern

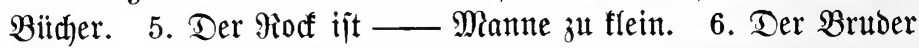
gibt —— Shwejter den Bleiftift. 7. Die Schwejter gibtBruber — Brief. 


\section{WRITTEN EXERCISE}

1. The mother buys the daughter shoes. 2. The shoes are too small for her. 3. She shows her the shoes. 4. The daughter says: "The shoes are big enough for me." 5. The father says: "The coat is not big enough for him." 6 . The tailor makes the coat bigger and brings it to the father. 7. The father gives him money for it. 8. To whom does the father give money? He gives it to the mother. 9. She buys the daughter dresses. 10. I give the money to you and not to them. 11. He shows the letter to her and not to him. 12. She brings us the books, and we bring them to you. 13. The father buys books for the son; he does not give him money. 14. Father and mother buy the children everything.

\section{LESSON VIII}

13. Past Tense of jein, to be, and haben, to have.

id) $\mathfrak{w a ̄ r}, I$ was.

Du wārit, thou wast, you were. er, fie, $\mathfrak{c}$ ş wār, he, she, it was. wir wāren, we were. ifhr wārt, you were. fie wāren, they were. Sie wāren, you were. idj hătte, I had.

Du hătteit, thou hadst, you had.

$\mathfrak{e r}$, jie, $\mathfrak{e} \mathfrak{s}$ hătte, he, she, it had.

wir hăttelt, we had.

ihr hăttet, you had.

jie hătten, they had.

Eie hătten, you had.

14. Past Tense of Weak (regular) Verbs: faujen, to buy, re'ben, to talk; ar'beiten, to work.

id faujte, I bought. ${ }^{1}$

Du faufteit, thou boughtest. ${ }^{2}$

$\mathfrak{e r}$, fie, es faujte, he, she, it bought. idi) rē'běte, I talked. ${ }^{1}$

Du rē'bètejt, thou talkedst. ${ }^{2}$

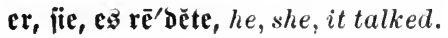

${ }^{1}$ Also I did buy, I was buying; I did talk, I was talking.

${ }^{2}$ Also you bought, did buy, were buying; you talked, etc. 
wir fauften, we bought. ihr fauftet, you bought. fie fauften, they bought. Sie faufter, you bought.

Singular

id) $\mathfrak{a} \mathbf{r}^{\prime}$ beitěte, I worked.

Du ar'beitětejt, thou workedst.

er, jie, $\mathfrak{e}$ a $\mathfrak{r r}^{\prime}$ beitěte, he, she, it worked. wir $\mathbf{r} \overline{\mathbf{e}}^{\prime} b \mathbf{s} t e n$, we talked. ihr r rē'bètet, you talked. fie rē'běten, they talked. Sie rés'běten, you talked.

\section{Plutral}

wir ar'beitěten, we worked. $\mathfrak{i} \mathfrak{j} \mathfrak{r} \mathfrak{a r}$ 'beitětet, you worked. fie ar'beitěten, they worked. Sie ar'beitěten, you worked.

15. Weak Verbs. - There are two classes of verbs in German, the weak and the strong. The weak verbs form the past tense by adding te to the stem, as: id faufte, I bought.

(1) Weak verbs whose stems end in $\mathfrak{d}, t$, or in $\mathfrak{n}, \mathfrak{n}$ preceded by a consonant, form the past tense by adding cte to the stem, as: öff'nen, to open, idf öff'ncte, I opened; at'men, to breathe, id at'mete, I breathed.

(2) The weak conjugation corresponds to that of the regular verb in English, as: 'I loved,' 'I worked'.

(3) Some weak verbs have certain irregular forms and can be classed as Irregular Verls, as: haben, to have, id hatte, I had.

Note. - @ein, like the English 'to be', is irregular throughout, the past tense being formed from a different stem from that of the present.

16. Position of nidft. - When nidgt modifies the whole sentence, it stands at or near the end; otherwise it comes before the word or phrase it negatives:

Bater liebte Den Şund nidyt, father did not love the dog.

Bater liebte Den Şumb aber nidgt bie Siabe, father loved the dog but not the cat. 


\section{VOCABULARY}

Der Iaijer, -, the emperor.

Der $\mathfrak{p u n d},-\mathfrak{c}$, the dog.

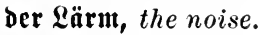

dic $\Re$ ăkze, $-\mathfrak{n}$, the cat.

dic $\mathfrak{F} \mathfrak{r a ̄ g c},-n t$, the question.

bas $\mathfrak{B i l}$, -er, the picture.

baz $\mathfrak{B i l}$ 'berbind, "

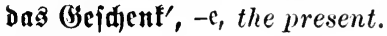

Inut, loud.

nūrr, only.

jdenten, to present, give. bellen, to bark.

trałzen, to scratch.

jāgent, to hunt, chase.

weilten, to weep, cry.

trïjiten, to comfort.

$\overline{\mathfrak{a}} \mathbf{t}^{\prime} \mathfrak{m e n}$, to breathe.

ïfinen, to open.

$\mathfrak{a} \mathfrak{3}$ (governs dat.), ${ }^{1}$ out of.

Danu, then.

ăl'jo, therefore, so.

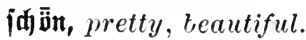

\section{READING EXERCISE}

1. Der Bater faufte Dem Sinde bas 3 udf). 2. Er fhentte

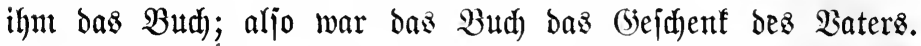
3. Seinrid) jeigte ez der Mitter und Der Edyejter. 4. Die

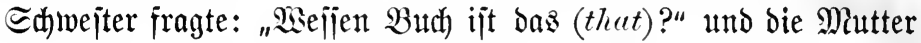

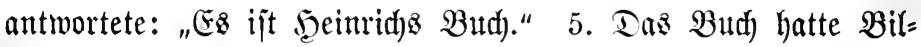

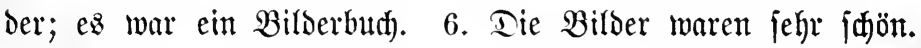
7. Der Sater und bie Mutter arbeiteten; bie Rinder fpielten und mad)ten viel Särm. 8. Der Şund war aud ba, und Seein= rid) jeigte dem Şunde bie Bilder. 9. "Weffen Bild ijt bas?" fragte Secinridy ben Şund, aber ber $\mathfrak{5 u m b}$ beflte $\mathfrak{n u r}$; er redete nicht. 10. Die Miutter antwortete: "Das ijt das Birb des Saijers." 11. "Wer ijt ber Saijer?" fragte das Rinto ben Bater, aber ber Sater hörte ihn nid)t; ber Seund beflte ju laut.

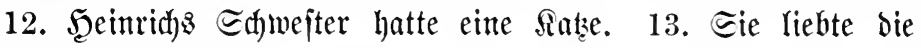

${ }^{1}$ As in German' some prepositions govern the genitive, some the dative, some the accusative, and some both the dative and the accusative, the case should be carefully learned with the preposition.

Complete lists will be given later in the lesson on prepositions. 
Sałze jehr, aber der Şund liebte fie nidyt. 14. Der Sumo

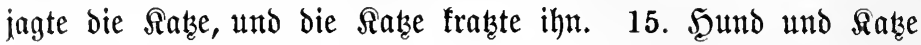
maren beide jehr jung. 16. Der Bater und bie Mutter liebten die Rinder aber nidgt den Şund und bie Rabse; Der Seund und die Sazze machten ju viel Särm. 17. Der Bater jagte ben

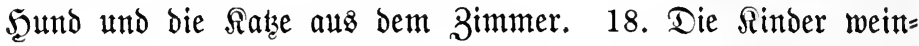
ten, aber bie Mutter tröjtete fie. 19. Die :ufit war fahlecht, und ber $\mathfrak{B a t e r}$ öfinete die Fenjter dez Zimmerz. 20. Sie at= meten Dann alle gute $\mathfrak{B u f t}$.

Questions. - 1. Waz faufte der $\mathfrak{B a t e r}$ dem Rinde? 2. Wem ichentte er bas $\mathfrak{B u c h}$ ? 3. Wem zeigte Seeinrid bas Buch)?

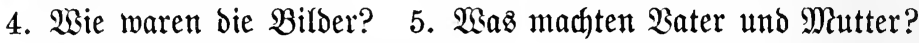

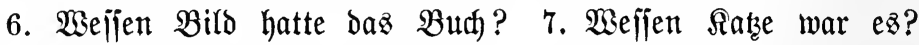

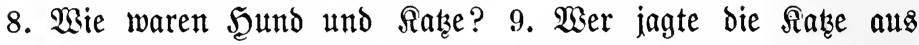
dem Zimmer? 10. Wer tröjtete die Rimber? 11. Wie war die Ruft bes Zimmers? 12. Wer öfifnete bie Fenjter?

\section{DRILL}

A. Conjugate: id atmete bie ?uft bes Zimmers; id öffnete daz Fenjter; id madhte viel Särm; id tröjtete bie Rimber.

B. Change in the Reading Exercise all the past tenses into present tenses.

\section{WRITTEN EXERCISE}

1: The mother bought her the book. 2. She presented it to Henry. 3. Henry was the brother. 4. Whose dog was it? It was Henry's dog. 5. Mary's cat scratched Henry, and he cried. 6. The mother comforted him and gave him a picturebook. 7. The sister loved the brother, and he loved her. 8. The brother chased the dog, and the dog barked. 9. The cat and the dog made too much noise, and the father chased them out of (aus) the room. 10. He opened the door for me 
(he opened me the door). 11. I opened the door for her. 12. I bought them the books. 13. We were working, and the children were playing. 14. Did you hear the dog, Mr. Meyer? Yes, I heard him; he made too much noise. 15. I heard her, but she did not hear me. 16. We breathed the air of the room.

\section{LESSON IX}

\section{REVIEW}

17. Review of Declension of Definite Article and Noun.

\section{SiNGCLAR}

N. Der Bater, the father.

G. D̆̌̉ Baters, of the father, the father's.

D. bem Bater, to the father.

A. bell $\mathfrak{B a t e r}$, the father.

N. bie Miutter, the mother.

G. Der Miutter, of the mother, the mother's.

D. ber Miutter, to the mother.

A. die Mutter, the mother.

N. Dăs Sind, the child.

G. Dĕs Rinbeß, of the child, the child's.

D. bem Sinoe, to the child.

A. băs Ritto, the child.

\section{Personal Pronouns.}

First Person

Singular

Nom. ìd, $I$.

Gen. meincr, of me.

Dat. mir, to me.

Acc. mĭd, me.
Pleral

bic $\mathfrak{B a ̈ t e r}$, the fathers.

ber $\mathfrak{B a ̈ t c r}$, of the fathers. bēu $\mathfrak{B a ̈ t e r n , ~ t o ~ t h e ~ f a t h e r s . ~}$ bie $\mathfrak{B a ̈ t e r}$, the fathers.

bie Miitter, the mothers.

ber Miitter, of the mothers. ben Mtïttern, to the mothers. bic Miitter, the mothers. Die Rinber, the children. ber $\Re$ indor, of the children. ben Rinbcru, to the children bie Rinber, the children.
Pleral

wir, we.

untier, of us.

uns, to us.

นกริ, us. 

N. Diu, you (thou).
Sic, you, (sing. and pl.).
G. beinter, of you. Shrer, of you.
ifrr, (pl. of bu) you.
D. Dir, to you.
Shuen, to you. cuer, of you.
A. bǐf, you.
Sic, you. cud), to you. eud), you.

Plukal

\section{Third Person}
N. $\overline{\mathrm{e}}$, he.
fic, she.
čss, it.
fic, they.
G. jeiner, of him.
ihrer, of her.
feiner, of it.
inrer, of them.
D. ihm, to him.
if)r, to her. ihm, to it.
A. ihn, him.
jie, her.
čs, it.
inutu, to them.
jic, them.

Note. - The genitive of the personal pronouns is not of frequent occurrence.

\section{Interrogative Pronouns.}

Nom. w⿳亠̄八, who?

Gen. weifen, whose?

Dat. wēem, to or for whom?

Acc. w⿳亠̄⿲二丨匕 whom? wăs, what?

weijen, of what?

wăs, what?

\section{Compound Nouns.}

(1) Compound nouns can be formed more freely in German than in English. They follow the gender and declension of the last component, as: dic 3im'merbe'dfe, the ceiling (ba 3immer, but dic Decfe) ; plural, die Bimmerdeden; die Şaustiir, the front door (১å Şaus, but dic Tiir); plural, die Şaustïren.

(2) Sometimes the first component may be a plural, as: oa Bil'berbudf, the picture-book; plural, bie Bilderbiid)er.

(3) Likewise the first component may stand in the genitive, as: bie Ta'gesar'beit, the day's work (Der Tag, the day); Der Sonnenjhein, the sunshine (Somnen being an old genitive of Sonne, sun). 


\section{VOCABULARY}

ber Sdjüler, -, the pupil, scholar. bag Edjulzimmer, -, the schoolber Bōben,", the ground, floor, bottom.

Der $\mathfrak{F} \bar{u} \mathfrak{k} \mathfrak{b} \bar{b} \mathfrak{n}, "$, the floor.

bie $\mathfrak{B a n t o}, " \mathrm{e}$, the wall.

bic Dedfe, $-\mathfrak{n}$, the cover.

bie Bimmerbedfe, -n, the ceiling. die Bettberfe, the bed-cover, spread.

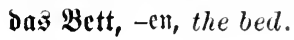

room.

jobelt, above, on top.

unten, below.

warun, why.

ficben, seven.

adjt, eight.

Dariu', in it, in them, therein.

Jrik, Fred.

\section{READING EXERCISE}

1. Das હaurjimmer hat vier জände uno jieben Fenjter. 2. Sben ijt bie Bimmerdecfe, unten ijt ber Jüboben. 3. Seier jint die \$ulte ber Edjitler, ba ijt bas Rult bez Sehrers. 4. Ter Sehrer jeigt ben Echitlern bas $\mathfrak{B u d}$ ) und fragt: "Was ijt bas auf bettjh?" und bie Edjitler antworten: "Das Buth." 5. "Weijen Buth ijt ez?" fragt ber Regrer. "Es ijt bas Bud bez Sehrers," antworten bie Edjitler. 6. Der Sehrer gibt bem Fritz bas Budf und fragt: "YSem gebe id) bas $B$ utd)?" "Sie geben es bem Frits" rufen bie Echiller. 7. Frił gibt bem Rebrer das Budh, uno ber Zehrer fragt: "Wem gibt Fritz oaz Budf?" "Er

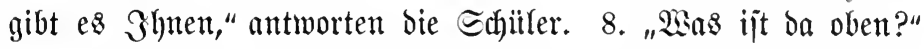
fragt ber Selhrer, und bie Shitler jagen: "Sben ijt bie Zimmer= Decfe." 9. Mas ijt bie Zimmerbedfe? Tie Zimmerdecfe ijt bie Decfe bes Zimmers. 10. Mas ijt bie Bettbecfe? Die Bettoecfe ijt bie Decfe bes Bettez. 11. "Mier bin ich?" fragt Der Sehrer. "Sie jint Der Rehrer, and wir find bie Erhitler," rufen bie Rin= ber. 12. Der Qegrer gibt ben Rindern bie $\mathfrak{B}$ üther, uno jie rejen barin. 13. Er jeigt ihnen Bilber utno fragt: "Waas jeige idf euth?" 14. Die Sinder antworten ihn auj beutid). 


\section{DRILL}

A. Give the case of each noun in the reading exercise.

B. Decline in the singular and plural: ber Edjiiler, bie

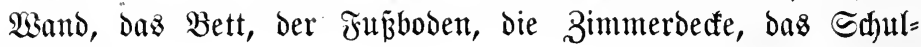
zimmer.

C. Give the dative case of: Sie (you); fie (she); jie (they); ber Sajiller; bie Wand; baz Bett; ber Stod; bie Banf; baz Bapier.

\section{WRITTEN EXERCISE}

1. The teacher showed her the pictures. 2. He showed them the books. 3. He did not show me the picture. 4. I give the teacher the letter. 5 . He reads it and gives it to me. 6. He sees her, but she does not see him. 7. We see them, but they do not see us. 8. The windows of the schoolroom are open (auff). 9. The walls of the room are white. 10. Fritz gives the teacher the pencil. 11. I am the teacher, you are the pupils. 12. He asked me: "Whom do you see?" and I said: "I see you, Mr. Brown." 13. Mother's book is not here, but there is father's book. 14. She answered 'me (dat.) in German. 15. I was above, and he was below.

\section{LESSON X}

21. Perfect Tense.

\section{Singular}

id) bin gewe' 'jen, I have been (was). Du bijt geweien, thou hast been.

er (jie, $\mathfrak{e}$ ) ijt gewe $\mathfrak{e n}$, he (she, it) has been.
Plural wir find geweien, we have been. $\mathfrak{i f h r}$ jeib gewe $\mathfrak{e n}$, you have been. fie fint gewejen, they have been. Sie fint gewejen, you have been. 
iđ habe gehăb't, I have had (I had). ou hajt gehabt, thou hast had. er (jie, e⿱彐⿰冫⿰亅⿱丿丶丶) hat gehabt, he (she, it) has had.

id $\mathfrak{h a b c}$ gefauft, I have bought, I have been buying, (I bought). bā hait gefauft, thou hast bought. er (jie, es) hat gefaujt, he (she, it) has bought. wir haben gehabt, we have had. ifjr habt gehabt, you have had. fic haben gehabt, they have had. Sie haben gehabt, you have had.

wir habelt gefauft, we have bought. ifhr habt gefauft, you have bought. jie haben gefauft, they have bought. Sic haben gefauft, you have bought.

So also: iff habe gear'beitet, I have worked (I worked). id) habc gcöff'nct, I have opened (I opened).

\section{Pluperfect Tense.}

id) war getwējen, I had been. Du warit gewejelt, thou hadst been. er war gewejen, he had been.

wir waren gewejel, we had been. ifr wart gewejen, you had been. fie waren geweicu, they had been. Sie waren gewejen, you had been. id) hatte gehăbt, I had had. bu hatteft gehabt, thou hadst had. er hatte gefabbt, he had had. wir hatteit gehabt, we had had. iffr $\mathfrak{h a t t e t} \mathfrak{g e h a b t}$ you had had. jie hatten gehabt, they had had. Sic hatten gehabt, you had had.

So also: id hatte gefnuft, I had bought, I had been buying. id hatte gearbeitet, I had worked, I had been working. id hatte geöfint, I had opened, I had been opening.

23. Past Participle. - In the above forms, gemejen, gehabt, gefaujt, geöfnet, gearbeitet are the past participles of the verbs.

(1) The past participle of a weak verb is generally formed by adding $\mathbf{t}$ or ct to the stem and prefixing $\mathfrak{g} \mathbf{e}$, as:

$\mathbf{Q o}^{\prime}$ ben, to praise; gelobt', praised.

Pie'sen, to talk; gere'bet, talked. 
(2) The past participle of weak verbs in German is never the same as the past tense (in English they are always the same), thus:

Ja) arbeitete, I worked; id habe gearbeitet, I have worked.

Er fauftc, he bought; cr hat gefaujt, he has bought.

(3) Unlike the English, the perfect and pluperfect tenses of fein (to be) are formed with the present and past tenses of jein itself, instead of haben (to have), as:

Ifh bin gemcien, 'I have been', idf war gemejen, 'I had been'.

a. As will be shown later, many intransitive verbs (verbs that cannot take a direct object) use fein as auxiliary, as: er ijt gereift, 'he has traveled'.

\section{Uses of the Perfect and Past Tenses.}

(1) In colloquial German the perfect tense is commonly used when referring to a single event or action in past time, while in English the past tense is used:

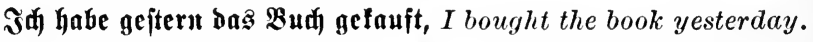
$\mathfrak{W o}$ jind Sie geitern gewejen? Where were you yesterday?

(2) The past tense is used in narrating past events in their relation to one another, - hence in narrative:

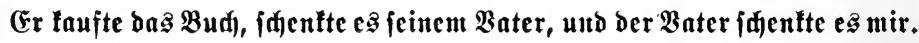
He bought the book, gave it to his father, and his father gave it to me.

25. Position of the Past Participle. - In main clauses the past participle stands last, as :

J⿹ bin gejtern nicht zu Şauje gewejen, I was not at home yesterday. Der Edneiber hat Dem $\mathfrak{B a t e r}$ Den $\Re$ of gemadt, the tailor made the coat for my father. 
26. Position of Adverbs of Time. - Adverbs of time usually precede all other modifiers of the verb, excepting pronouns not governed by a preposition:

Wir Gaben lange nicht in Dem Barten gearbeitet.

We have not been working in the garden for a long time.

Sater hat mir geitern bas Buth gej(henft.

Father gave me the book yesterday.

\section{VOCABULARY}

bor (3arten, *, the garden. ber $\mathfrak{A}$ bett, -e, the evening.

erbelt, to inherit.

mieten, to rent, hire.

wohnen, to live, dwell.

wie geht ez $\mathfrak{g h n e n}$ ? how are you? e's gefjt mir ganz gut, I am very well.

felbit, self; id jelbit, I myself. befier, better. früfyer, earlier, formerly. lange (adr.), long, for a long time. $\mathfrak{g e}^{\prime}$ itern, yesterday. jełzit, now. Derut (conj.), for. bci (prep. gov. dat.), at, by, at the house of.

in (gov. dat. when no motion is implied toward the object of the preposition), in.

\section{READING EXERCISE}

1. Wo jind Eie gejtern abent gewejen, Frau Braun? $g$ 中 bin bei Fraut Miener gewejent. 2. Wie geht ez ifr? Ez geht ihr jetzt beffer, aber jie ijt lange jehr frant gerwejen. 3. Wiohnt jie nidyt in Bojton? Piein, aber fie hat frither ba gerwohnt, jetzt wohnt jie in Philadelphia. 4. Şat beerr Meber hier bas Şauz getauft? Tiein, er hat es nur gemietet. 5. Er hatte das

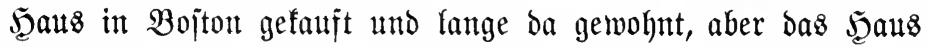
war ihm zu Hlein, bent er hat fïnj Sinber. 6. Frau Meyer hat mir das Bill des Seaujes gejeigt. 7. Serr Meyer hatte

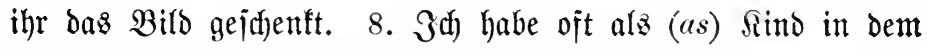
(Sarten des Saujes gejpielt, denn wir haben aud) frither in 
Bojton gewohnt. 9. Seerr Meyer hat viel in bem (Sarten ge= arbeitet. 10. Er hat viel (beld in Bopjton gemad)t, aber er hatte audh etwas (Seld geerbt. 11. Şatte Frau Meyer nidjt bas Geld bez Baterz geerbt? Sa, fie hat es geerbt, aher es war nidjt jehr viel. 12. Wie geht es \$hnen jelbjt, Frau Braun? Danfe, es geht mir jekzt ganz gut, und ben Sindern geht ez aud bejier.

\section{DRILL}

A. Conjugate: idh labe das Şaus gefauft; id bin geitern

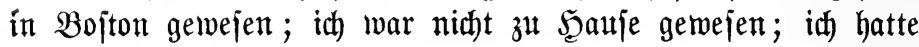
in bem (siarten gearbeitet.

B. Form the past participles of the following weak verbs: lernen, antworten, lieben, loben, fragen, jagen, weinen, tröjten.

\section{WRITTEN EXERCISE}

1. Where has Charles been? He has been in the garden. 2. He has been working (has worked) there. 3. The father had bought the garden. 4. Charles has lived a long time in Boston. 5. He has shown me the house. 6. We have often played in the house. 7. The mother has inherited the house, but not the money. 8. The house was too big for her, and she does not live there. 9. How are you, Mr. Meyer? I am quite well, thank you. 10. The children had been crying, but the mother has comforted them, and now they are playing together in the garden. 11. The weather has been, very bad, and we have not been in the garden for a long time. 12. Whose house have you rented? We have rented the house of Mrs. Brown. 


\title{
LESSON XI
}

\section{Declension of Pronominal Adjectives}

Singular
Plural

\section{Masculine}
N. bie'jer Mann, this man.
die'je Mlänner, these men.
G. Dieje: Mianne , of this man. biejer Miänner, of these men.
D. biejen Manne, to this man. dicien Mläunern, to these men.
A. biefen Mann, this man. bieje Mlänner, these men.

Feminine
N. bie'je Frau, this woman.
G. biejer Frau, of this woman.
D. bicjer Frau, to this woman. A. Diefe Frau, this woman.

bie'fe Frauen, these women. bicjer frauen, of these women. diefen Frauen, to these women. Dieje Jraucu, these women.

Neuter

N. Die'je: Bud, this book.

G. Diejes Budies, of this book.

D. biejem Budje, to this book.

A. biefes $\mathfrak{B u d}$, this book. bie'fe Büdfer, these books. biejer Büd)er, of these books. biejen Buidjern, to these books. bieje Bidjer, these books.

(1) Like biefer are declined: jener, that; weldyer, which; jeder, every; mandjer, many a; joldher, such $(a)$, thus:
N. jëner Bater.
jëbe Fraut.
wef(t)e Ba Butd).
G. jēneß Bater:.
jëser Frau.
welct)es Butthes.

\author{
ete.
}

(2) Notice that the case-endings are the same as those of the definite article ber, bie, $\mathrm{Das}$, excepting that the neuter nominative and accusative singular endings are $\mathfrak{s}$; hence these six pronominal adjectives and the definite article are commonly called 'Der words'.

(3) Instead of jener (that), the demonstrative Der, bie, das ( $\$ 101)$, is commonly used in colloquial German. It is dis- 
tinguished from the definite article by greater stress in the pronunciation:

Ter Miaun', the man; but bēr' Maum, that man;

Jit baz' Das Budi)? Is that the book?

$\mathfrak{B a r}$ ba's bic Mutter? Was that the mother?

Das' find bie Bücher, those are the books.

a. Notice that as subject of fein the demonstrative baz remains uninflected, the verb agreeing with the predicate noun.

28. Rule for Gender. - Nouns ending in $\mathfrak{c}$ are (with but few exceptions) feminine, unless denoting masculine living beings. For examples see Vocabulary below.

\section{VOCABULARY}

Der (B̧ärt'ner, -, the gardener.

ber $\mathfrak{i t p}$ 'fel, ", the apple.

ber $\mathfrak{B a u m}$, "e, the tree.

ber $\mathfrak{I p f e l}\left(\mathfrak{b a u m ,} "{ }^{\mathrm{e}}\right.$, the apple-tree.

dic Birne, -n, the pear.

bie $\mathfrak{B l u m e},-\mathfrak{n}$, the flower.

bie $\mathfrak{B l i i t e ,}-\mathfrak{n}$, the blossom, bud.

die $\Re$ ioje, $-\mathfrak{n}$, the rose.

die $\mathfrak{M l f f e},-n$, the pink.

$\mathfrak{d n} \mathfrak{3} \mathfrak{a} \mathfrak{h r}$, -e, the year.

je'bermann, everybody, everyone. piliuffen, to pick.

pilantzen, to plant.

bliihen, to bloom, blossom.

reif, ripe.

$\mathfrak{u} \mathfrak{t}^{\prime} \mathfrak{r e i f}$, unripe.

friil), early.

wun'beriđüu, very beautiful.

intuter, always.

(id)on, already.

$\mathfrak{h e u}$ 'te, to-day.

heute frïh, early this morning.

\section{READING EXERCISE}

1. Du bijt in biejem (Sarten gewejen, $\mathfrak{i a r l}$; mas hajt bu ba gemadht? $\Im_{\mathfrak{d}}$ habe der Miutter bieje S̈lpfel gepflïft. 2. Sind bie s̈ipfel juon reif? 9itat alle, bieje jind reif, aber bie ba (those there) jind nod) nidgt reif. 3. Weldher $\mathfrak{B a u m}$ hat foldhe S̈pper? Diejer Baum. 4. Der (Särtner war jưn in bem (Sarten getwejen und hatte bieje Ï̈pfel uno Birnen gepfliüt. 
5. Mandhe S̈lpfel waren aber nitht reif, er hatte jie ju frith gepflitut. 6. Soldhe ïlpfel faufe idh nidft, jie jind nidft reif. 7. Geber âpfel und jebe Birne in biejent Barten ijt reif. 8. Water hat jenen Baum gepflanjt, aber biejer (this one) ijt immer in bem (Sarten gewejen. 9. Sieldye Blumen bajt du gepflitft, Marie? Ga) habe bieje Yiojen uno jene Pelfen ge= prlitaft; id bin heute frith) in bem (Sarten gemejent. 10. Sebe Blume briil)t. 11. Sisir haben bieje Błumen gepflanjt uno aud) mandhen Baum. 12. Tie Błäten biejer ?(pfelbäume jino biejez Gahr wunderidjön gewejen. 13. Viidgt jebermann hat foldhen Barten uno foldhe Bäume uno Bhumen!

Questions. - 1. Wso mar Sarl gewejen? 2. WSas hatte cr ba gemadft? 3. Maren bie S̈lpfel fafou reif? 4. Wiser war iffon in bent Barten gemejen? 5. Wer hat jenen Baum getillanjt? 6. Sielde Blument hatte Maric ge=

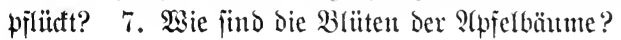

\section{DRILL}

A. Decline in the singular and plural: weldye Bhume, mandher atpjel, jenes Budf), bieje Mutter, jeser Siater (sing. only).

B. Conjugate: id habe biefen Baum gepflanjt; hatte id jolde $\mathfrak{B l u m e n}$ geprlitut?

\section{WRITTEN EXERCISE}

1. Max has planted these flowers. 2. Which flowers has he planted? These pinks and roses. 3. Mary has picked these apples. 4. Which pears are ripe? These are ripe, but those are not yet ripe. 5. This apple is not ripe, but that pear is ripe. 6. Father has planted every tree in this garden. 7. We had been in that garden and had picked these flowers. $8 . \mathrm{He}$ has picked every flower. 9. I do not buy such flowers, we have them in the garden. 10. This man's garden is very 
beautiful, he has such roses and pinks! 11. Many a tree has blossoms now, and many a flower is blooming. 12. Everybody has such a garden, but not everybody has such flowers. 13. For which children did you buy pears? For these children.

\section{LESSON XII}

\section{The Indefinite Article and fcin.}

Masculine

N. cin Mann, a man.

G. cine $\mathfrak{B}$ Mannez,

D. einem Manne,

A. cinen Mann,
Feminine

cine Frau, a woman. einter $\mathfrak{F r a u}$, eister Frau, cine Frau,
NedTER

cin $\mathfrak{B f e r d}$, a horse. cines $\mathfrak{P F e r d e z ,}$ einem Pferbe, eit $\mathfrak{B f e r b}$,

Fin $(a)$ can, of course, be declined only in the singular.

Masculine Singular

Nom. fein Brief, no letter.

Gen. feines Briefez, of no letter.

Dat. feinem Briefe, to no letter.

Acc. feinen Brief, no letter.
Masculine Plural

teine Briefe, no letters.

feiner Briefe, of no letters.

feitren Briefen, to no letters.

feine Briefe, no letters.

(1) Notice that fein is declined like cin in the singular and like biejer in the plural:

Reine Frau, no woman; feil $\mathfrak{B f e r b , ~ n o ~ h o r s e ; ~ f e i n e ~ B u ̈ d e r , ~ n o ~ b o o k s . ~}$

(2) This declension differs from that of biejer only in the nominative singular, masculine and neuter, and in the neuter accusative singular, which are' without case-endings. In the nominative singular, therefore, the gender of masculine and neuter nouns is not distinguished by the form of ein:

Masculine: eit Bater; but, biejer $\mathfrak{B a t e r}$.

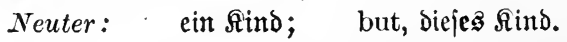


(3) When emphasized, ein should be translated 'one', thus: EFin Bud', 'a book'; but, ciu' $\mathfrak{B u d}$ ), 'one book'.

a. Ein meaning 'one' is sometimes printed with spaced letters. The use of spaced letters in German corresponds to the use of italics in English, as: EFin Mam, 'one' man.

\section{Possessive Adjectives.}

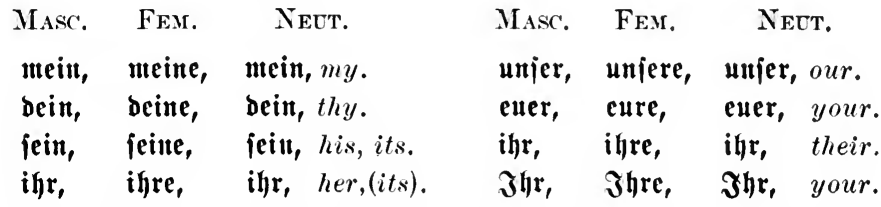

(1) The possessive adjectives are declined like ein, eine, ein and fein, feine, fein, thus:

Masculine

N. mein Bruber.

G. meines Brubers.

D. meinten Bruber.

A. meinen Bruber.

N. meine Britber.

G. meiner Briber.

D. meinen Briibern.

A. Iteine Britber.
Feminine ihre Hoje. ihre Mioje. il)rer Hoje. ibre Hioje. ihre Mojen. ihrer Siojen. ihren Mojest. ihre Mojen.
Necter ŭmier Budf. unjerez Budjes. unjerem Bude. unjer Bud. unjere Bitder. unjerer Biidjer. ustjeren Büđern. unjere Büder.

(2) In unfer and euer the ending $\mathfrak{c r}$ is part of the stem and not an inflectional ending, hence: umjer $\mathbf{L a t e r}$, and also unfer $\mathfrak{B} \mathfrak{u} \mathfrak{d}$; although $\mathfrak{B u d}$ ) is neuter.

(3) The corresponding personal pronouns and possessive adjectives are best shown as follows:

id) Gabe ntein Buth), I have my book.

bu Gajt beit Bu(f), thou hast thy (you have your) book.

er Gat jeit $\mathfrak{B u ( h )}$, he has his book.

fie hat ifyr $\mathfrak{B u}(\mathfrak{h})$, she has her book.

ez (Das Sind) hat jein Buth), it (the child) has its book. 
wir haben unjere Büther, we have our books. ihr habt cure Bücher, you have your books. fie Gaben ihre Büther, they have their books. Eic haben Jhre Bürther, you have your books.

(4) The pronoun ऽie (you), and the corresponding possessive adjective $\mathfrak{G h r}($ your), are written with capitals to distinguish them in writing from jie (she, they), and ihr (her, their), and from the pronoun ihr (plural of dit, you).

a. Like the English 'you' and 'your,' હie and $\mathfrak{J h r}$ may refer to one or more persons.

(5) Ein, fein and the possessive adjectives are commonly called the 'ein words'.

\section{VOCABULARY}

ber Bleijtift, -e, the pencil. bie $\mathfrak{A} u \mathfrak{f g} \overline{\mathfrak{a}} \mathfrak{c},-\mathfrak{n}$, the exercise, task. bie Tinte, $-n$, the ink. bie $\mathfrak{P}$ rbeit, -ell, the work. bic reder, $-n$, the pen. baz Stüt, -e, the piere.

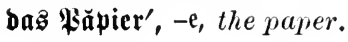

bå Etiid $\mathfrak{B a ̆ p i e r ' , ~ t h e ~ p i e c e ~ o f ~}$ paper. $\mathfrak{b a z} \mathfrak{W} \mathfrak{u} \mathfrak{t},-\mathfrak{e}$, the desk. flīg, clever, smart, intelligent. fiir (prep. gov. acc.), for. $\mathfrak{z}_{\mathfrak{u}}$ (prep. gov. dat.), to. bami, then.

\section{READING EXERCISE}

1. Frits, hajt but meinen Bleijtift? Rein, Stto, idh habe Deinen $\mathfrak{B}$ leiftift nidht, aber hier ift eine Feder. 2. Эa) habe aber feine Tinte. 3. Şier ijt Tinte und aud ein Stiut $\mathfrak{B a p i e r .}$ 4. Danfe, aber idf brauthe fein Fapier, id habe mein Syejt.

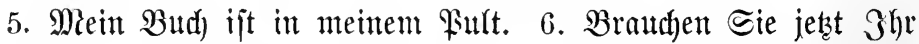
Buth, Serr Edfwarj? Piein, hier ijt mein $\mathfrak{B u d}$ und aud ein Bleiftift. 7. Stto hat jetzt einen Bleiftift, eine Feber, Tinte und fein Şeft. 8. Er macht jeine 2lufgabe. 9. Dann jagt er z̆u feinem Sefrer: "llnjere $\mathfrak{A}$ ufgaben jind fehr fahwer." 10. Der

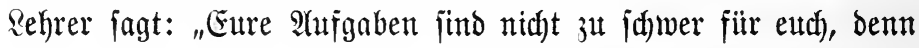


ihr feio alle jehr flug." 11. Der Qehrer lobt feine Edjitler, benn jie haben ihre 9 urgaben gut gemad)t. 12. Emma hat ihre $\mathfrak{T}$ rbeit bejier als Etto gentad)t. 13. Emma ijt jeine Edjwejter, aljo ijt er ifr Bruber. 14. Sein Sind hat jeine Irbeit idfledt gemadyt. 15. Der Pefrer jagt zut jeinem $\Xi$ djitler Dtto: "Wie geht ez beinem Sater? id höre, er ijt franf." 16. "E\& geht meinent Siater befier," antwortet ミtto, "aber meiner Miutter gebt es nicft jo gut."

\section{DRILL}

A. Decline the singular and plural: mein Bleiftift, beine Feder, jein Sinto, ihr Sater, Ghre Erbwejter, unjer Pult, eure $\mathfrak{T} \mathfrak{u} \mathfrak{j g a b e}$ fein Fapier.

B. Continue the follouing ( 1 s in $30,{ }^{3}$ ): id habe meine Alufgabe gemtad)t, Du hajt beine, ete.; id) brauthe mein $\mathfrak{B u d}$; id liebe meinen 2 ater; id) habe meinen $B$ ruber gelobt; ing jebe meine $\subseteq$ (b) wejter; id) leje meinten $\mathfrak{B r i e j}$.

\section{WRITTEN EXERCISE}

1. Fritz has my pen, and I have his pencil. 2. Emma has her pen, but she has no ink. 3. Our desks are in our schoolroom. 4. These pupils have their books. 5. Have you your book, Mr. Black" Yes, I have my book here. 6. We have our copy-books, but we have no paper. 7 . Here is a piece of paper. 8. Her father and her mother are not at home; they are in Boston. 9. Have you their letter? No, I have no letter. 10. He showed me his exercise; it was very bad. 11. Have you two pencils? No, I have only one pencil. 12. He loves his father and his mother, and they lore their son. 13. They have two sons and one daugliter. 14. She has a brother but no sister. 15. He has a sister but no brother. 


\section{LESSON XIII}

\section{Future Tense.}

iđ wërbe jein, I shall be. bu wirit jein, thou wilt be. er wird fein, he will be. wir wērben fein, we shall be. ihr wērbet fein, you will be. fie wērben feilt, they will be. Sie wērben jein, you will be. id) werbe hāben, I shall have. bu wirit haben, thou wilt have. cr wirb haben, he will have. wir merben habed, we shall have. ifr werbet haben, you will have. jie merben haben, they will have. Sie werben haben, you will have.

So also: id werbe faufen, I shall buy; id werbe arbeiten, I shall work; id werbe werben, I shall become.

\section{Future Perfect Tense.}

(a) of jein:

id werde gewejen fein, I shall have been.

bu wirit gewejen feilt, thou wilt (you will) have been.

er wirb gewejen jein, he will have been.

wir werben gemejen jein, we shall have been.

ihr werbet gewejen jeit, you will have been.

fie werben gewejen jein, they will have been.

Sie werben gewejen fein, you will have been.

(b) of habet:

id werbe gehabt haben, I shall have had.

bu wirit gehabt haben, thou wilt (you will) have had.

er wirb gehabt haben, he will have had.

wir werben gehabt haben, we shall have had.

ifhr werbet gehabt haben, you will have had.

fie werben gefabt haben, they will have had.

Sie werben gehabt haben, you will have had.

So also: iđ werbe gefauft haben, I shall have bought; id werbe gear= beitet haben, I shall have worked; iff werbe geworben fein, I shall have become. 
(1) Notice that the future tense, like the perfeet, is a compound tense. It is formed by the present tense of werben, as auxiliary, and the infinitive of the verb.

(2) The future perfect is formed by the present tense of merben and the perfect infinitive. In idf werbe gewejen jein, gemejen jein is the perfect infinitive, corresponding to 'have been' in English.

(3) In German the present tense is used for the future more commonly than in English, as: $\mathfrak{G d}$ faufe morgen baz $\mathfrak{B} \mathfrak{u d}), 1$ shall buy the book to-morrou, I am going to buy the book tomorrow.

(4) The future is often used instead of the present, and the future perfect instead of the perfect, to express probability. $\mathfrak{W} \mathfrak{o h l}$ is added to strengthen the meaning, as:

Err wirb wohl Gier jein, he is probably here.

Er wirb wohl hicr gewejen jeit, he has probably been here.

33. Position of the Infinitive. - In main clauses the infinitive, like the past participle, stands last:

$\mathfrak{J} \mathfrak{d}$ twerbe murgen $\mathfrak{j} u$ baulj fein, I shall be at home to-morrow.

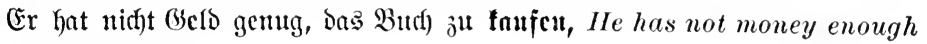
to buy the book.

(1) An infinitive stands after a past participle, when both occur in one sentence:

Bis morgen mirb er ba gewejen jein und das belo getholt haben.

By to-morrow he will have been there and have fetched the money.

\section{Imperative Mood.}

SingULAR

\{ei, be (thou, you). hābe, have.

mădje, make, do.
Plunal,

feib, be (ye, you). $\mathfrak{h a b t}$, have. madt, make, do.
Sing. And Pl.

jeicn Sic, be (you). haben Gic, have. madien Sie, make, do. 
(1) As in English, the imperative expresses command, e.g.:

(a) Sei ruhig, Iarl! Be quiet, Charles.

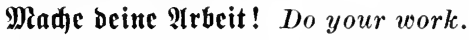

(b) Seib ruhig, Rinber! Be quiet, children. Madjt cure $\mathfrak{A r b e i t ! ~ D o ~ y o u r ~ w o r k . ~}$

(c) Scien Sic ruhig, Scrr $\mathfrak{B r a u n}$ ! Be quiet, Mr. Brown. Miadjen Sie $\mathfrak{J}$ re $\mathfrak{A r b e i t ! ~ D o ~ y o u r ~ w o r k . ~}$

Notice that $(a)$ is the form of the imperative used when the pronoun of address would be bu; $(b)$ is the plural of $(a)$, and $(c)$ is the form of the imperative when the pronoun of address would be Sie. (Cf. $\S 1^{2}$ and $30^{3}$.)

(2) The imperative singular of a weak verb is formed by omitting the $\mathfrak{n}$ of the infinitive:

feil, to be; jei! be. arbeiten, to work; arbeite! work.

(3) The imperative with the pronoun Sie, has the same form as the question:

Madjen Sie $\mathfrak{s h r e ~} \mathfrak{A} \mathfrak{u} \mathfrak{f g n b e}$ ? Are you doing your exercise? But, Madjen Sie $\mathfrak{J h r e} \mathfrak{T} u \mathfrak{f g} \mathfrak{a} \mathfrak{e}$ ! Do your exercise.

\section{VOCABULARY}

ber Spielplak, "e, the playground. ruhig, quiet, still. ber $\Re \bar{e} g e n$, the rain.

$\mathfrak{B i l}$ 'helm, William.

$\mathfrak{b a z} \mathfrak{S} \mathfrak{G} \mathfrak{a}$, "

$\mathfrak{g l a u b e n ,}$ to believe, think.

bauen, to build.

fojten, to cost.

rēgnen, to rain.

böfe, angry, wicked, evil.

morgen, to-morrow.

bald, soon.

wohl, probably; well; to be sure. mit (prep. gov. dat.), with, along with.

bitte (for iđ bittc, I beg), please.

\section{READING EXERCISE}

1. Cei ruhig, Wilfelm! Bater wird bich hören und wird böje merben. 2. $\mathfrak{B a t e r}$ wirb bald zu Şaute fein und mird mit 
dir ipielen. 3. Wir merden in unjerem Sarten ipielen.

4. Sagen Sie mir bitte, ந̌err Braun, haben Sie einen (Sarten? Nein, aber idh werbe ein $\mathfrak{5}$ aus mit einem (Sarten faujen; die Sinder werben bann einen Epielplaţ haben. 5. Wsir werden

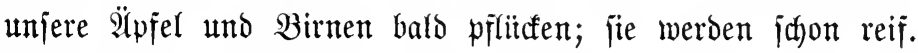
6. Wo wirb ber Seeinrid) wohl gemejent jein? (Fr mird wohl in bem Sarten gemejen jein und wird älpjel gepfliidt haben. 7. Pfliide bie Birnen nidht, Seinrich, jie jint nod) nidht reif! 8. Ya, aber jie werben bald reif werben. 9. Madje beine Irbeiten, Seinrid)! $\mathfrak{F}$, Mutter, id) werde jie bald gemadyt haben. 10. Seib ruhig, Sinber, id höre Den Bater! 11. Bater, bie Mutter jagt, ou wirit mit mir in bem Sarten ipielen. 12. Pein, Bithelm, wir werden in dem $\mathfrak{H a u j e}$ ipielen, denn es regnet

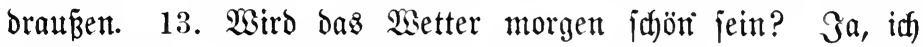
glaube, wir werben morgen feinen Megen haben.

\section{DRILL}

A. Conjugate in the future and future perfect: id werbe

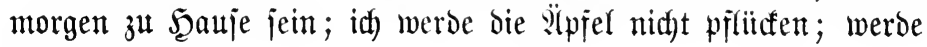
id) (bell haben?

B. Change the following imperatives to the form with Sie:

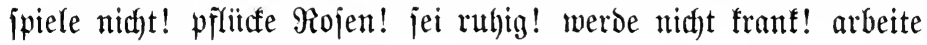
fleip̈ig! zeige mir bas! Yiebe ihn! Yobe jie!

C. Give the three forms of the imperatire of: jagen, faufen, bauen, reden, weinen, öfinen, jayen, idjenfen.

\section{WRITTEN EXERCISE}

1. Be good, children. 2. Do your work, Henry. 3. Tell me please, Mr. Brown, will you buy a house with a garden? No, but we shall rent a house and a garden. 4. We shall not have enough money to buy a house. 5. Buy the house, Mr. 
Brown, and you will have a playground for your children. 6. This house will have cost very much to build. 7. Mary will have shown you the garden but not the house. 8 . The gardener will have been there and will have picked the apples and pears. 9. Our gardener will have done the work. 10. Will it rain to-morrow? Yes, I believe we shall have rain to-morrow. 11. Will you be at home to-morrow, Mr. Brown? Yes, I shall work at home. 12. You will work to-morrow, but I shall play.

\section{LESSON XIV}

\section{REVIEW}

\section{Review of the Verb.}

\section{Infinitive Mood}

Present: jein, to be. hāăben, to have. măăden, to make. Perfect: gewejen jein, to have been. gehabt haben, to have had. gemad)t haben, to have made.

Indicative Mood

Present Tense

idf bin, I am. id habe, I have. idf madhe, I make. bu bijt, thou art. Du hajt, thou hast. Du mad)jt, thou makest. er ift, he is. er hat, he has. er madft, he makes. twir jinto, we are. wir haben, we have. wir madhen, we make. ihr jeit, you are. ifgr habt, you have. ifgr madft, you make. jie jino, they are. jie gabell, they have. jie madfen, they make.

\section{Past Tense}

id) war, I was. id) hatte, I had. idf madfte, I made. Du warijt, thou wast. Du hattejt, thou hadst. Du mad)tejt, thou madest. er war, he was. er hatte, he had. er madfte, he made. wir waren, we were. wir hatten, we had. wir madten, we made. ifr wart, you were. ifr hattet, you had. ifr madftet, you made. fie waren, they were. fie hatten, they had. fie madften, they made. 


\section{Perfect Tense}

I have been (was, etc.) I have had

id) bin gemejen

ou bijt getwejent

er ijt gewejen

wir jüto gewejeut

ibr jeio gemejen

fie find gewejen

\section{I had been}

id) twar gemejen

bu warit gewejen

er war gemejen

mir waren gewejen

ify wart getwejen

jie waren getwejen

\section{I had had}

ict) habe gefabt

Dut hajt gehabt

er hat gebabt

wir haben gehabt

ihr $\mathfrak{h a b t}$ gebabt

jie haben gebabt

Pluperfect Texse

ich) Gatte gefabt

ou hatte je gebabt

er hatte gebabt

wir hatter gehabt

ihr hattet gehabt

fie batten gebabt

\section{Fetere}

\section{I shall be \\ idf) iwerde fein \\ du wirjt fein \\ er twiro fein \\ mir werben jein \\ ihr merbet jein \\ jie werben jein}

I shall have

ich) rerbe baben

ou mirjt baben

er mird baben

wir werben haben

ifge werdet haben

fie werden habent
I have made

id) habe gemadit

ou hajt gemacht

cr hat gemad)t

wir haben gemad)t

ifr habt gemadyt

fie haben gemad)t

\section{I had made}

id) hatte gentadit

Du hattejt gemad)t

er hatte gemadit

wir hatten gemad)t

ifre battet gemadyt

jie hatten gemadht

\section{Future Perfect}

\section{I shall have been}

id) werde getuejen jein Du wirjt gemejen jein er wirb gerwejen feit

\section{I shall have had}

iif) werbe geffabt haben ou wirjt gehabt haben ex wiro gebabt baben

\section{I shall make}

idf metbe madten bu mirjt madfen er wirb madyen wir merden machen ifgr werdet madten jie twerben madyen wir werden gewejen fein wir werben gebabt haben wir merden gemadht haben ifgr werdet gemejen feit ihr merdet gefabt haben ihr werdet gemadht hahen jie werden gewejen jein fie werben gehabt haben fie werden gemad)t haben 
Imperative Mood

$\begin{array}{llll}\text { Singular, } \quad \text { fei, be. } & \text { habc, have. } & \text { madje, make. } \\ \text { Plural, } & \text { jeid, be. } & \mathfrak{h a b t , ~ h a v e . ~} & \text { madjt, make. } \\ \text { Sing. and Pl., feicn Sie, be. } & \text { haben Sie, have. } & \text { madjen Sic, make. }\end{array}$

\section{Oral or Written Review.}

1. Give the third person singular of all the tenses of the following weak verbs: zeigen, jāgen, arbeiten, İrnen, braudjen, ipielen, ant= worten, faufen, lōben, lieben, rēben, fĭjenten.

2. How is the past participle of a weak verb formed, and how the past tense?

3. What position have the past participle and infinitive in a main clause?

4. When is the perfect tense used in German; when the past tense?

5. In what case does the subject of a sentence stand? the direct object? the indirect object? Form sentences in German to illustrate this.

6. Decline in the singular and plural: biefer Miau, weldje frau, jenes $\mathfrak{g a u s , ~ m e i n ~ B r u b e r , ~ i h r e ~ S d j w e j t e r , ~ f e i n ~ S i u t b , ~ b e r ~ L e f r e r , ~ b i e ~}$ $\mathfrak{R o j e}$, bas $\mathfrak{B u d}$.

7. Give the dative and accusative of the following pronouns: idf, Du, er, fie (she), wir, ihr, fie (they), Sie, wer, es.

8. Explain the difference in use of the three pronouns of address: ou, ifr, Sie.

9. Give genitive case of: wer, ber Sccintid), Marie, meine Mutter, Jyre Büder, dicjer Bater, weldes $\mathfrak{B u d}$.

10. Place the definite article before the following nouns: Stoff, Budd, Feder, Blciftift, Bapicr, Tafel, Rrcibc, Edjwejter, Brief, Better,

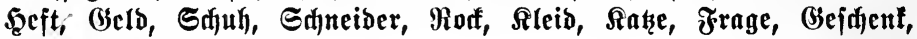
(Sarten, Plbend, Raifer.

11. Which case of all nouns ends in $\mathfrak{n}$ ?

12. Of what gender are most nouns ending in $\mathfrak{e}$ ? Give three such nouns.

13. Wherein does ein differ in its declension from bicjer?

14. Which are the so-called 'Der words', which the 'ein words'?

15. Translate: 'I have it' (the stick); 'he has it' (the pen); 'she has it' (the book). 


\section{VOCABULARY}

\$ans, Jack.

Der Striff, -c, the rope.

ber Bogel, ", the bird.

Der Simmel, -, the sky, heaven.

Der Steru, -e, the star.

(Suteı Morgen (ace. case), good morning!

die $\mathfrak{k a n t}, "$ e, the hand.

bie Miitze, $-\mathfrak{n}$, the cap.

bic (Sscididite, $-\mathfrak{n}$, the story.

bie Errbe, $-n$, the earth.

bic Sonne, -nt, the sun.

Dåz $\mathfrak{\Re} \mathfrak{a} l \mathfrak{b}, \boldsymbol{*}^{\mathrm{er}}$, the calf. bag Dorf, "er, the village.

Daz Spicl, -e, the play, game.

begēgnen (gov. dat.), to meet.

fïhren, to lead.

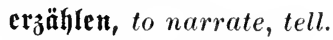

fejthalten, to hold fast.

redt, right, very.

nahe, near.

fern, distant, far.

burd) (gov. ace.), through.

$\mathfrak{g a r}$ viel, very much.

ăb, off .

$\breve{\mathfrak{b} b}$, whether.

\section{Lauts und das Kalb}

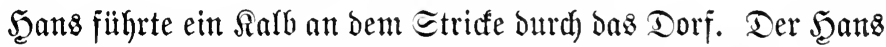

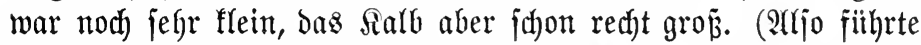

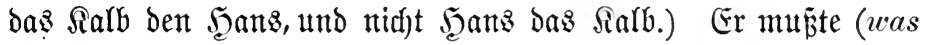
obliged) den Striaf mit beiben Şänden feithalten. (Ta (then) be= gegnete er jeinem Sebrer. "Guten Morgen," jagte Şans, und "Sitten Morgen," antwortete Der Refrer. "IYGer warum nimmit (take) but bie Miitze nicht ab?" fragte ber Rehrer. "Walten Sie

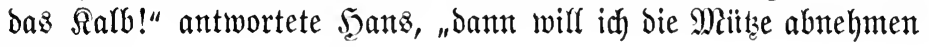
(take off)."

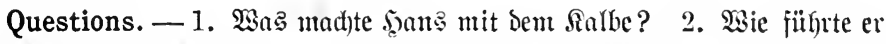

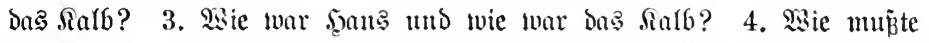

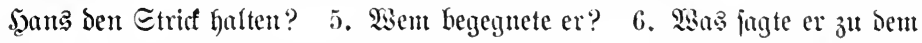

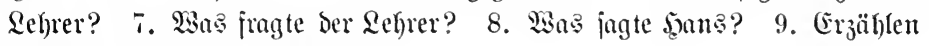
Sie bieje (bejd)idt) auj Teutidn!

2. Sd) liebe bie $\mathfrak{B l u m e n , ~ i d ~ l i e b e ~ b a s ~ E p i e l , ~}$ Эa) liebe bie Bögel, id liebe gar viel, Die Froe, den Şimmel, bie 巨onne, ben Etern, Эd) liebe bas alles, ob naly' ober fern. 


\section{LESSON XV}

\section{Position of the Verb in Independent Clauses.}

a. Cein Bater $\overline{\overline{\mathfrak{h}} \text { at }}$ ihm geitern baz $\mathfrak{B u d}$ getaujt. His father bought him the book yesterday.

b. (Seftern $\frac{2^{\text {nd }}}{\mathfrak{h a t}}$ fein $\mathfrak{B a t e r} \mathfrak{i h m}$ daz $\mathfrak{B u d}$ gefauft.

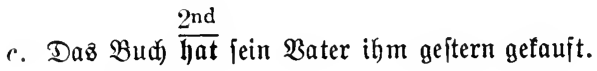

a. $\Im \mathfrak{h m} \frac{2 \text { nd }}{\mathfrak{h a t}}$ (ein $\mathfrak{B a t e r}$ geitern baz $\mathfrak{B u d}$ gefauft.

(1) From the above examples it is seen that any word (with its modifiers) may begin an independent clause, but that the finite verb must always stand second.

Note.-Placing geitern, $\mathfrak{a} \mathfrak{B} \mathfrak{B} \mathfrak{4}$, and ifm first in the sentence makes them emphatic.

(2) By the 'finite verb' is meant that part of the verb which is inflected in number and person; hence the finite verb in the above sentences is $\mathfrak{j a t}$, not gefaujt which, as a past participle, stands at the end of its clause.

(3) The same rule for position holds good with the simple tenses of the verb, thus:

f̧icr biu idf), here I am; idh biu hier, I am here.

(4) Notice that the subject, if not first in the clause, generally comes immediately after the verb. It may, however, be separated from the verb by a pronoun; as:

Daş $\mathfrak{B u}$ hat hat ifjm jeiu Bater gejtern gefauft.

38. Normal Order. - When the subject stands first in the clause and is immediately followed by the verb, this order of words is called Normal Order (see $3 i, a$ ). 
39. Inverted Order. - In a simple declarative sentence, when some other word than the subject stands first, the verb must be placed before the subject, and the order of words is called Inverted Order: see $37, b, c$, and $d$.

a. In German, as in English, the inverted order is used in questions and in the imperative:

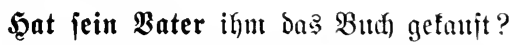

Has his father bought him the book?

Saufen Eie baş Bữ)! buy the book.

40. Coördinating Conjunctions. - The general connectives,

\begin{tabular}{|c|c|}
\hline $\begin{array}{l}\text { ŭnto, and, } \\
\text { ober, or, } \\
\text { Děntr, for, }\end{array}$ & $\begin{array}{l}\text { āber, } \\
\text { jŏndern, } \\
\text { allein', }\end{array}$ \\
\hline
\end{tabular}

do not count as first words, and hence do not affect the order of a clause; for they only connect clauses, without belonging to them, thus:

Bater hat Das $\mathfrak{B u d}$ gefauft, aber er hat ę̧ mir nidft gegeben.

Father bought the book, but he did not give it to me.

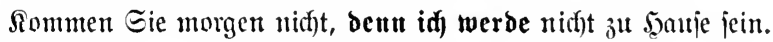

Do not come to-morrow, for I shall not be at home.

(1) Sonbern introduces a statement which excludes or contradicts a negative statement just made:

Err gat nifft gearbeitet, fontorn gejpielt, he did not work, but played. SBir woh)nen nidft in ber Etabt, fondern auj bem Lande.

We do not live in town, but in the country.

(2) 2frlein introduces a clause expressing a strong contrast to the idea of the preceding clause:

(Er hat Deutifh in ber Edfule, allein er ift faul und lernt nidft?. IIe has German at school, but he is lazy and learns nothing. 
(3) The conjunction 'for' is Denn; but the preposition 'for' is fiit :

Er faufte bą̧ Scats nicht, beut er hatte fein (bels.

IIe did not buy the house, for he had no money.

Er hat vicl bseld fïr bas şaus gegeben.

He paid a great deal of money for the house.

\section{VOCABULARY}

Der \$ōif, "e, the yard, court.

bie Miartitināie, - It, Market Street.

bie Mriete, $-\mathfrak{n}$, the rent.

die Etabt, "e, the town, city.

bas $\mathfrak{Q} a n d, \mathbf{n}^{\mathrm{er}}$, the land, country.

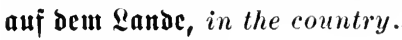

$\mathfrak{b e} \mathfrak{a}^{\mathfrak{a}} \mathfrak{h}^{\prime}\{\mathfrak{e}$, to pay.

beju'd)en, to visit.

hóf'jentlid (adv.), it is to be hoped,

I hope, etc.

nifit mchr lange, not much longer.

ăls, than. nid)t als, nothing but.

$\mathfrak{h} \overline{\mathbf{o}} \mathfrak{h}$, high .

ounfel, dark.

billig, cheap.

billiger, cheaper.

teuer, dear.

tcuercr, dearer.

zientlid, fairly.

jiemlid) viel, rather much.

gleid), (adv.), at once.

waun (interrog.), when.

vŏu (prep. gov. dat.), of, frcm, by .

\section{READING EXERCISE}

1. Wanm haben Sie ein $\mathfrak{T a u z}$ gefautt, Serr Braun? (Sejtern habe idh ein Şauz gefauft. 2. Weldyez Şauz haben Cie

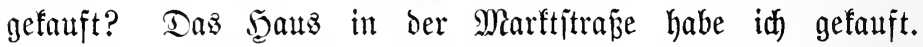
3. Warum haben Sie daz Şauz nid)t gemietet? Эn ber Miarftjtraß̉e jinto bie Mieten jehr hod), befjer ijt ez, eit Seaus gleid) ju faufen. 4. Şat bas Seaus einen (jarten? Rein,

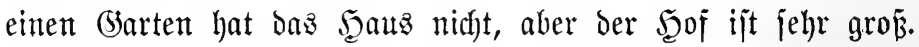
5. Meine Frau liebt einen (Jarten, Denn fie hat immer auf bem Ranbe gewohnt und einen (5arten gehabt, allein hier in ber Stabt haben bie Seäufer feinen Sarten, jondern mur einen Seof. 


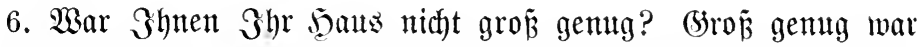

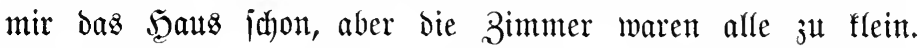

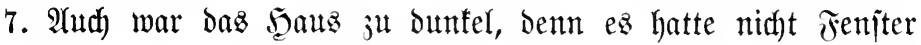
genug. 8. Şaben Sie viel fïr baz baus bejahlt? Ziemlidh

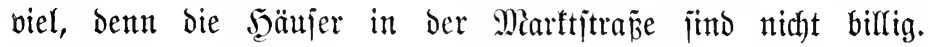
9. $\mathfrak{H}$ uf dem \&ande jinto bie Şäujer billiger, denn daz \&ano ijt nid)t jo teuer. 10. Soffientlid) werbe id) Iange in biejem Sauje wohnen. 11. Meine Frau und bie Sinter fint jeţt auf bem Rande, Denn das sietter ijt jel)r warm, und meine Fran ijt niát jehr wohl. 12. Şaben Sie ein Sauts auf dem :ande gemietet?

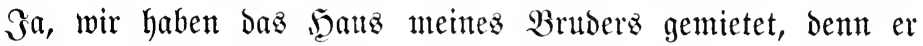
ano feine Frau jind jetst in Berlin. 13. WSie lange jind jie

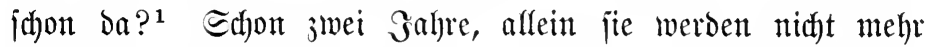
lange ba wohnet. 14. (Gejtern hatte idh einen Brief von ihm, id) hatte idfon lange nitht von ihm gehört. 15. Seine Sinder find nidht in Berlin, jondern auf bem :ande. 16. Seoffentlich haben jie gut Deutidy gelernt, denn jie gören nichtz alz Deutid).

${ }^{1}$ In German the present tense is used (generally with an adverb of time) to denote that which was and still is, hence here: How long have they been there?

Questions. - 1. Wann hatte berr Braun ein baus gefauft? 2. Wo mar das bans? 3. Warum bat er bas baus nicht gemictet? 4. Satte ba: Saus einen barten? 5. Sinb bie seänier billiger auf bem Sanbe als in ber Stndt? 6. Satte er bas .̧aus auf bem Sambe gemietet noer gefauft? 7. Weijen Şat war es? 8. Wo wohute Der Buber? 9. Wo twaren jeine Sinder?

\section{DRILL}

Give in all possible worl-positions: 1. Er mirb morgen ein

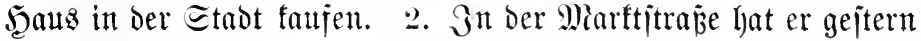
ein Şaus gemietet. 3. Sie find jwei Jahre in Berlin ge= wejen. 4. Sie hören nid)tz als Deutid) in ber Edule. 


\section{WRITTEN EXERCISE}

1. Yesterday he rented a house on (the) Market Street. 2. He did not buy the house, for he had no money. 3. The house has no garden, but only a yard. 4. He had always lived in the country, for he loves the country, but his wife does not love it. 5. How much does he pay for the house? Not much, for the house is small and dark. 6. The house is not big enough for him, but the houses on Market Street are all small. 7. To-day his wife and children are in the country, for his children are not well, and the weather is very warm. 8. In the country the houses are cheaper. 9 . In the town the houses have no gardens. ${ }^{1}$ 10. They are living in the house of his mother, for she is living in Dresden. 11. How long has she been ${ }^{2}$ there [already]? She has been there three years. 12. She has learned German, for she hears nothing but German at home. 13. To-day he had a letter from her. 14. Now she is not in Dresden, but in Berlin. 15. She is visiting her sister, for her sister lives in Berlin. 16. I hope she is well, for she has been very ill. 17. To-morrow I shall visit him; I hope he will be at home. 18. To-day and tomorrow he will be at home, for he is working in the house.

${ }^{1}$ Cf. Reading Exercise, sentence 5. The German singular expresses the idea that each house has one garden. $\quad{ }^{2} \mathrm{Cf}$. Reading Exercise, sentence 13.

\section{LESSON XVI}

\section{STRONG VERBS}

\section{Past Tense of Strong Verbs.}

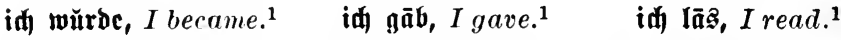

bu wărbeit, thou becamest. bu gāâjt, thou gavest. bu lāît, thou readest.

er wŭrbe, he became.

$\mathfrak{e r} \mathfrak{g} \overline{\mathfrak{a}} \mathfrak{b}$, he gave.

er $\mathfrak{l a}$ ș, he read.

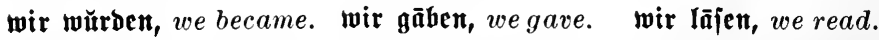
ihr wŭrbet, you became. ihr gāabt, you gave. ihhr lāît, you read. fie wŭrben, they became. fie găben, they gave. fie lāj

Nore. - Also: I was becoming, I was giving, I was reading. 
As seen above, the past tense of strong verbs is formed by a change of the root-vowel, called $\mathfrak{a b l a u t ~ ( c h a n g e ~ o f ~ s o u n d ) . ~}$ The first and third persons singular have the same form (compare in English: I became, he became; I gave, he gave).

Note. - Burbe, unlike other strong verbs, has the ending $\mathfrak{e}$; there is, however, in the singular an older form: id, wărd, bu wăroft, er wăro, which is still in use in poetical language.

\section{Perfect Tense of Strong Verbs.}

\section{iđ biut gewŏrben,}

I have become.

bu bijt geworben,

etc. id) habe gegēêben,

I have given.

bu hajt gegeben,

etc.

\section{iđ̆ habe gelējen,}

I have read.

ou fjajt gelejest,

etc.

The past participle of strong verbs is formed by prefixing $\mathfrak{g} \mathfrak{e}-$ to the stem and adding $-(\mathfrak{c}) \mathfrak{n}$. The vowel of the stem may be like the vowel of the infinitive, or like the vowel of the past tense, or it may be an entirely different vowel.

Note. - Werben, like fein, takes fein as auxiliary. Never use haben with gewejen and geworden!

43. Principal Parts of Verbs. - The infinitive, the past indicative, and the past participle are called the principal parts of a verb, because all the other parts can be formed from them.

(1) Of regular weak verbs only the infinitive need be given in vocabularies, as the principal parts are formed according to the rules already given in Lessons VIII, 15, and X, 23, as:

Epielen, ipielte, geipielt, play, played, played. Saufen, faufte, getauft, buy, bought, bought.

(2) With strong verbs, however, it is necessary to learn, not merely the infinitive, but also the past indicative and the past participle of each verb; because the change of vowel (ilblaut) 
varies, and a classification is of little use to the beginner (compare in English: write, wrote, written; come, came, come; sit, sat, sat).

$a$. In the vocabularies the three principal parts of the verb are given when the rerb is strong; when not given, it may be assumed that the verb is weak, thus: (weak) fpielen, to play, but (strong) geben, gah, gegeben, to give.

\section{Synopses of Strong Verbs in the Indicative Mood.}

Principal. Parts

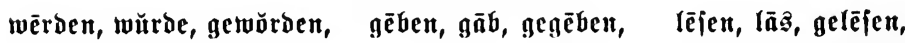
become, became, become. give, gave, given. read, read, read.

PRESENT Tense 1

id werbe, I become. $\quad$ id gebe, I give. id leje, I read.

Past Tense

id wurbe, I became. id gab, I gave. id laß, I read.

\section{Perfect}

id bill geworben,

I have become.

id war geworben,

I had become.

id werbe werben,

I shall become.

idf werbe geworben jeill, I shall have become. idi habe gegeben,

I have given.

\section{Pluperfect}

id hatte gegeben,

I had given.

FUTCRE

id werbe geben,

I shall give.

Future Plerfect inf habe geleien, I have read.

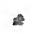
id) hatte gelejen, I had read.

idf werbe lejen, I shall read. werbe gegeben habeu, werbe gelejen haben, I shall have given. I shall have read.

${ }^{1}$ For complete conjugation of the present tense of these three verbs see Lesson VI. 


\section{VOCABULARY}

Note. - Intransitive verbs taking fin as auxiliary are indicated in the vocabularies by ift, as: firgen, flog, iit gefrogen, to fly. Hence: or ift geflogen, he has Hown. All other verbs take habell (see Lesson XVIII).

Der $\Re$ rūğ, "e, the jug, pitcher. Der $\mathfrak{\text { gals, }}$ "e, the neck. ber Stein, -e, the stone. Die Îrühe, $-\mathrm{n}$, the crow. Das $\mathfrak{W a j i} e r$, , the water. jünjen, to seek, look for. fiutben, fano, gefŭnden, to find. flicgen, flōg, ift geflōgen, to fly. ftehen, ftăno, geftănden, to stand. wĕrfen, wă:f, gewŏrien, er wirft, to throw. fteigen, ftieg, ift geftiegen, to mount, rise, climb.

trinfen, tranf, getrunfen, to drink. ouritig, thirsty. halb, half. voll, full. woll $\mathfrak{B a}$ ijer, full of water. feit, firm, firmly. endidi), at last, finally. wě̉̆, away. ge $\overline{\mathbf{e}}^{\prime} \mathbf{g e n}$ (prep. gov, ace.), against.

\section{Die Iŕnähe und der Zirug}

Cine Sirähe wurbe jehr duritig, benn das Wetter war febr warm geworben. Eie judte lange Sajier und entidid fand jie einen Sirug. Tlber ber Sirug war mur halb voll Saffer, und

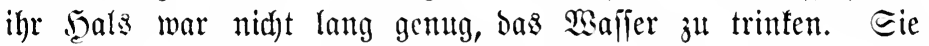
flog gegen ben Sirug, aber ber Sirug jtand jut fejt. Tann warf jie Stcine in ben Irug, und marf fo lange, bis bas Sajfer fitieg. Fann trant bie Srälye und flog weg.

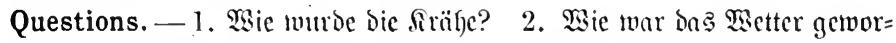

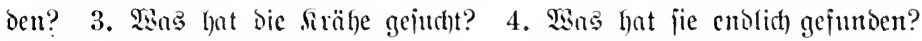

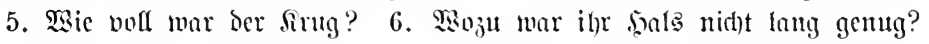

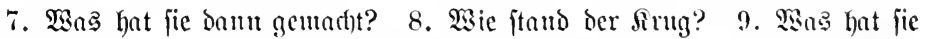

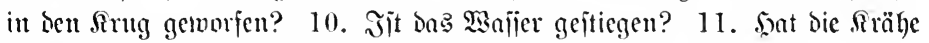

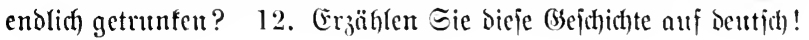

\section{DRILL}

A. Conjugate: id) fand bas Saljer; id habe ljer gejtanden; id) werbe feinen Stein merfen; id) trant bas sajjer; id) wurbe nicht frant; bin idh fleişig gemorden? 
B. Give the third person singular of all tenses of: finden, fliegen, jtehen, jteigen, juchen, trinfen.

C. Give the principal parts of: fein, haben, werden, faufen, geben, lejen, arbeiten, jpielen, reben, regnen.

\section{WRITTEN EXERCISE}

1. The weather became very warm. 2. The crow has become very thirsty. 3. The bird is seeking water. 4. I shall give the bird water. 5. The crow drank the water and flew away. 6. What have you found? I have found this book, but I have read it already. 7. He had given the book to his sister. 8. His sister threw the book away. 9. I found it and read it. 10. Did you throw that stone? No, I did not throw the stone. 11. He threw a stone at (nad), dat.) the crow and it flew away. 12. She stood there and read the letter. 13. She had looked for the letter, and at last she had found it. 14. Karl is drinking too much water; he will become ill. 15. He has not been here, for he has become very ill. 16. It rained, and the pitcher became half full of ${ }^{1}$ water. 17. We drank the water, for we had become very thirsty.

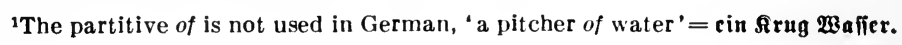

\section{LESSON XVII}

45. Present Tense of Strong Verbs. - The present tense of both strong and weak verbs is formed by adding the proper personal endings to the verb-stem:

i(f) fŏmm-e, I come.

bu fŏmı-it, thou comest.

or fŏmm-t, he comes.

etc. i(f) lēe-c, I live.

ou lếb-it, thou livest.

er lēb-t, he lives.

etc. 
(1) Most strong verbs with the stem vowel $\mathfrak{c}$ change the $\mathfrak{c}$, when short, to $\mathfrak{i}$ in the second and third person singular; if the $e$ is long, to ic (see Lesson VI):

idx) hălíe, I help.

ou hilffit, thou helpest. er billft, he helps. idi) lēie, I read. bu lic $f$ t, thou readest. er licit, he reads.

(2) Most strong verbs with the stem-vowel $\mathfrak{a}$ modify it to $\ddot{\mathfrak{a}}$ in the second and third person singular, as:

id) rāte, I advise, guess.

Du rätft, thou advisest.

er rät, he advises. wir rāten, we advise.

ihr rātet, you adrise.

jie rāten, they advise.

Note. - These changes in the second and third persons present of strong verbs will be indicated in the vocabularies by giving the third person singular, thus:

rāten, riet, geraten (rät), to advise.

$\mathfrak{g} \overline{\mathfrak{e}} \mathfrak{b} \mathfrak{c}, \mathfrak{g} \mathfrak{a} \mathfrak{b}, \mathfrak{g e g c b c}$ (gibt), to give.

lēien, Ias, gelejen (lieft), to read.

\section{Imperative of Strong Verbs.}

\section{Singular}

gĭb, give.

lics, read.

rāte, advise.

wēroc, become.
Pletral

gēbt, give.

Iềit, read.

rātet, advise.

wēroct, become.
Sing, AND PL.

gāêen Sic, give.

Iējeı Sie, read.

rāten Eic, advise.

wērocn Eic, become.

Strong verbs (except merben) with the stem-rowel $\mathfrak{c}$ which change in the second and third persons singular to $i$ or $i c$, undergo the same change in the imperative singular and omit the ending $e$.

Other strong verbs form the imperative according to the rule given for weak verbs in Lesson XIII, 34 (2). In colloquial German the ending $\mathbf{c}$ is frequently omitted, as:

rāt! guess. faứ'! buy. fŏmแ! come. glaub' mir! believe me. 
47. Inseparable Verb Prefixes. - There are two kinds of prefixes to verbs, 'inseparable' and 'separable':

Inseparable

bezaf'len, to pay.
Separable

ans' zahlen, to pay out.

(1) An inseparable verb-prefix is always written with the verb as one word (compare also in English: reform, perform, inform, deform, etc.).

The accent falls on the verb: $\mathfrak{b e} \mathfrak{z} \mathfrak{a})^{\prime} \mathfrak{L} \mathfrak{e n}$, verfau'fen (to sell).

(2) The inseparable compound verb is conjugated like the simple verbs, excepting that the $\mathfrak{g} \mathfrak{c}-$ of the past participle is omitted, thus:

verfau'fen, verfauf'te, verfauft', sell, sold, sold.

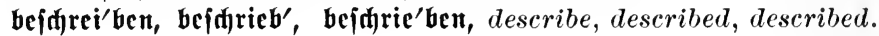

(3) The inseparable verb-prefixes are: $\mathfrak{b c}-, \mathfrak{c n t}_{-}, \mathfrak{c n t p}-, \mathfrak{c r}_{-}$, $\mathfrak{g c}-, \mathfrak{v e r}-, \mathfrak{z}^{\mathfrak{c r}-}$.

$a$. The inseparable prefix generally changes the meaning of the verb, as:
faufen, to buy;
but verfau' $\mathfrak{i} \mathfrak{e}$, to sell.
fommen, to come;
“ betom'men, to receive, get.
reidjen, to reach;
" $\quad$ errei'd)en, to attain.
loben, to praise;
treten, to step, tread;
" gelo'ben, to vow.
“ zertre'tcit, to trample on.

b. These prefixes, too, form verbs from nouns and adjectives, as:

$$
\begin{aligned}
& \text { Saaupt, head; enthaup'ten, to behead; } \\
& \text { rōt, red; }
\end{aligned}
$$

c. 3er-conveys generally the idea of 'to pieces', as: breden, break, zerbre'dien, to break to pieces; ent- the idea of separation, as: laufen, to run, entlau'fen, to run away. The meaning of the other inseparable prefixes is, in many cases, somewhat obscured. 


\section{VOCABULARY}

rāten, riet, gerāten, (rät), to guess, advise.

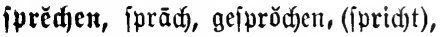
to speak.

foumes, fām, ifit gefommen, to come.

(d)reiben, idfrieb, gefdrieben, to write. bejd)rei'ben, bej(f)rieb, bej(f)rieben, to describe.

befom'men, befām, befommen, to receive, get.

vertau'fen, to sell. zerifăl'len, zerfiel, ift zerfăllen, (zer= fällt), to fall to pieces.

gelō'bent, to vow. bewōh'uen, to inhabit. errö'ten, to blush. un'āartig, naughty. wert, worth. ērjt (adv.), first. vōr'geiteru, day before yesterday. nic'mals, never. nēbenan, next door. vor Freube, for joy.

\section{READING EXERCISE}

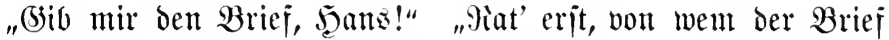

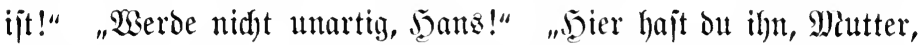
uno mun liez ihn!" Tanu gibt hanz jeiner Miutter ben Briẹ. Eie liejt ilnn und errötet vor Frende. Tann fommt Seer

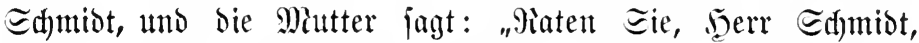
von wem wir einen Brief befommen haben!" Serr હdjmist rät uno fragt: "Ysann haben Cie den Briej befommen?" "Sejtern haben wir ifn befommen, uno Bater batte ihn bor= gejtern gejarieben," antwortet Şans. "Siann fommt er nad) Şauje?" "Wiorgen," antwortet Miutter. "Er hat baz Jeauz verfauft und viel Gelo bajiir hefonmen. Tas ந̧aus war alt und jerfallen, aber baz 'and war viel mert. Eein Sater hatte gelobt, es niemals zu vertanfen, aber wir haben es jabon lange nidht bewohnt." "Miein Siater hat mir oft bas baus bejarie= ben," fagt Seerr Edhmiot, "Denn er bewohnte lange bas Şaus nebenan." 
Questions. - 1. Mag jagte bie Mutter? 2. Mag fagte Sean? 3. Seat Senns feiner Mitter ben Brief gegeben? 4. Bon wem war ber Brief? 5. Sanu hatte Der Bater Den Brief gej(f)rieben? 6. Wann foumt Der Bater nadh saufe? 7. Sag hatte ber Sater berfauft? 8. Sag hatte er Dofïr befonmen? 9. Sie war bas soms? 10. Wer hatte lange in bem Ђ̊nile nebenan gewognt?

\section{DRILL}

A. Conjugate in the present tense: in (predfe nidft; id jarreibe einen Brief; idf leje bas $\mathfrak{B u d}$; idf rate es nid)t; befonme id) (stelo?

B. Give the three forms of the imperative of: ipred)en, idfrei= ben, fommen, berfaujen.

C. Give the first person singular perfect tense of: verfaufen, betommen, getoben, bejareiben, bewohnen, wohnen.

\section{WRITTEN EXERCISE}

1. Guess who is coming, Karl. 2. Read the letter first and then give it to me. 3. Do not get (become) naughty, Karl, for father is coming. 4. She gives him the letter, and he reads it. 5. Who has sold the house? Mr. Smith has sold the house and received the money for it. 6 . Describe the house to me. It is old and is falling to pieces. 7. The house is not inhabited. 8. He spoke to ( $\mathfrak{k}$, dat.) me yesterday and advised me (dat.) to buy the house. 9. He had described it to us. 10. The house next door is not inhabited. 11. He has vowed not to sell the land, for it is worth very much (viel wert). 12. Sell the house and get (receive) the money, Mr. Smith. 13. He blushed for joy. 14. Day before yesterday I received the letter, and to-day he came. 


\section{LESSON XVIII}

\section{Use of}

(1) Gaben is used, as auxiliary, with the past participle of all transitive verbs (verbs which can take an object), thus:

Jof habe ifm gejefren, I hare seen him.

(Er hat bas Bunf getaut, he has bought the book.

a. This is also true of some intransitive verbs (verbs which cannot take an object), as:

Jd) $\mathfrak{h a b e} \mathfrak{g e j t a n b e r t , ~ I ~ h a v e ~ s t o o d . ~}$

Jd) habe geiejien, I have sat.

(2) Sein is used, as auxiliary, with the past participle:

$a$. of intransitive verbs expressing change of place (motion from one place to another), as:

Er iit gefommen, he has come.

Er ijt in bie Etabt gegungen, he has gone into town.

Jd) biu geiprungen, I have jumped.

Ias Sino war gefallen, the child har fallen.

b. of many intransitive verbs expressing a chunge of condition, as:

Er ijt gejtorthen, he has died.

Eie war frant gemorom, she had become ill.

Siart ijt jefre gewadjicr, Charles has grown very much.

$c$. of the following special verbs: jein, bleiben (to remain), gejd)ehen (to helplen), gelingent (to surceed), as:

WBir find $\mathfrak{j}$ u şauje geblicben, we (hare) stayed at home.

Note. - As fein is used as anxiliary with many intransitive verbs which in English use 'have', (are should be taken when learning intransitive verbs to learn the auxiliary with which they form their compound tenses (see note to rocabulary of Lesson XVI). 
49. Conjugation of Intransitive Verb with Auxiliary jeitt. gehen, ging, gegangen, to go, walk.

Present: id gehe, I go, am going, do go.

PAST: in ging, I went.

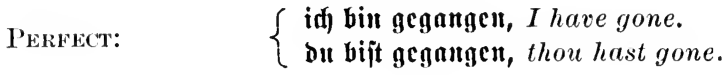

etc.

Pluperfect: $\quad\left\{\begin{array}{l}\text { id } \text { war } \mathfrak{g e g a n g e n ,} \text { I had gone. } \\ \text { bu warit } \mathfrak{g e g a n g e n},\end{array}\right.$ etc.

Futere: $\quad$ idf werbe gehen, I shall go.

Future Perfect: $\quad\left\{\begin{array}{l}\text { id werbe gegangen jein, I shall have gone. } \\ \text { bu wirjt gegangen fein, }\end{array}\right.$ etc.

Also in the same way: iff fomme I come; idf fam, I came; idf) bin getommen, I have come, etc.

\section{VOCABULARY}

ocr Infcl, -, the uncle.

ber $\mathfrak{B e t t e r},-n$, the cousin.

bie Gtultoc, $-\mathfrak{n}$, the hour.

bie Sdjūle, $-\mathfrak{n}$, the school.

die Tănte, $-\mathfrak{n}$, the aunt.

bleiben, blieb, ift geblieben, to stay, remain.

wadjien, wŭdyz, ift gewădujen, (wäd)it), to grow.

Iaujen, lief, ijt gelaufen, (läuft), to run.

ipringen, iprang, iit geiprungen, to spring, jump.

fallen, fiel, iłt gefăllen, (fällt), to fall.

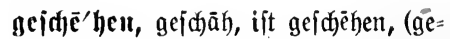
(d)ieft), to happen.

itčrbest, itărb, ift geitŏrberi, (jitirbt), to die.

nchucn, nahm, genommen, (nimmt), to take.

leben, to live.

vergci'jen, vergāâ, vergeffen, (ver= gi $\bar{B} \mathrm{t})$, to forget.

trà̄gen, trūg, getrāgen, (trügt), to carry.

rujen, rief, gerufen, to call.

"ōr vielen Sabren, many years ago. 


\section{READING EXERCISE}

Wann ift $3 \mathfrak{h}$ Better geitern getommen? Er ift friih ge= fommen, aber er ijt nidgt lange geblieben. Sisie lange ijt er geblieben? Thur orei ober vier Stunden. Er ijt jehr (very much) getwad)jen, er ijt ganj groß̉ geworden. Sein Bater hat ihn aus ber Edulle getrommen. Meein Better jagte: "Jat habe eud) alle nicht vergejien." Er vergi ijt in ben Garten gegangen uno hat gejagt: "W̌ier hat Snfel mid) als sinto genomment und ijt mit mir gelaufen uno ge=

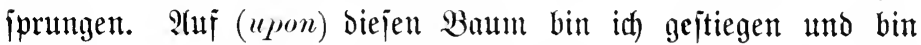
gefallen, uno Dnfel hat midh in das ந̌ans getragen uno nadh (for) ber Tante gerujen. Das ijt allez vor vielen Gahren ge= idjehen. Dnfel trägt mich jeţt nidht, idh bin ihm ju id)wer geworden." Sit jeine Wiutter nicht gejtorben? Ja, aber jein Bater lebt nod). Er ijt ju j̧alje geblieben, er ijt lange nicht jehr wohl gewejen, aber ez geht ihm jeb̨t bejijer.

\section{DRILL}

A. Give the perfect tense of: bleiben, wadbjen, fallen, jpringen, laujen.

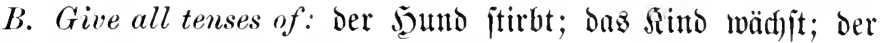
Better fällt; er jteigt auf ben Baum.

'C. Change all perfect tenses in the Reading Exercise into past tenses.

\section{WRITTEN EXERCISE}

1. My uncle has come, but my aunt has remained at home. 2. My cousins have grown very [much]. 3. They have gone into the garden. 4. They will have forgotten us. 5. What has happened? My cousin had jumped and fallen, and my 
father has carried him into the house. 6. He has become very heavy. 7 . We had remained at home, for the weather had been very bat. 8. Who is calling? Your cousin is calling; he has gone into the house. 9. Who has died! His aunt has died. 10. She had become very old. 11. Did he stay at home? Yes, but he went into the garden. 12. It had happened many years ago, but he had not forgotten it. 13. Do not forget me 14. The child has fallen. Carry him home.

\section{LESSON XIX}

\section{Separable Verb-Prefixes.}

(1) Most of the prepositions can be used as spparable verbprefixes, as:

mit'arbeiten, to work with, coöperate; auf' $\bar{f}^{\prime} \mathfrak{c h} \mathfrak{h} \mathfrak{c h}$, to go up, rise.

(2) The separable prefixes of verbs in independent clauses are detached from the verb in the simple tenses (present and past) and in the imperative, and usually stand at the end of the clause:

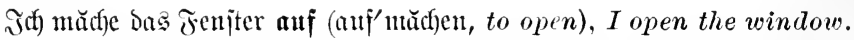

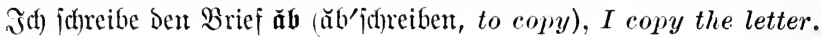

(3) Separable prefixes always take the chief accent, as: auf'madhen, ab'ifhreiben, amf'gehen.

(4) In the infinitive with $\mathfrak{z} \mathfrak{u}$, the $\mathfrak{j} \mathfrak{u}$ stands between the separable prefix and the verb, and the three form one word:

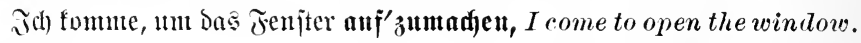

(5) The $\mathfrak{g} \mathfrak{c}$ of the past participle likewise stands between the separable prefix and the verb:

Jah habe bas Feniter anf'gemadht, I have opened the window. 
51. Conjugation of a Separable Verb.

$$
\text { aนf'แnădjen, to open. }
$$

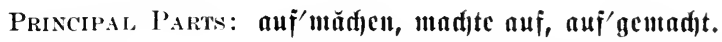

Present. idf mad)c bic Tïr auf, I open, am opening, do open the door.

PAst. idf mad)te bie Tïr auf, I opened the door.

Perfect. id) habe bie Tür aufgemad)t, I (have) opener the door. Picperfect. id hatte bic Tür aufigemadyt, I had opened the door. Future. id werbe bie Titr aujmadjen, I shull open the door. Future Perfect. idf werde dic Tiir aufgemad)t haben, I shall have opened the door.

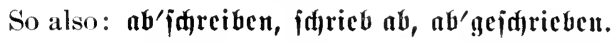

Present. id jojreibe beu Brief ab, I am copying the letter. PAst. id jarieb ben Brici ab, I copied the letter. Perfect. id habe ben Brief abgeid)rieben, I (have) copied the letter.

\section{IMPERATINE}

SingULaR.

Plural.

Sing. and Pi. madie bie Tïr auf! open the door. ja)reibe ben Brici ab! copy the letter.

mad)t bic Tïr auf! open the door. idjrcibt ben Brici ab! copy the letter.

madjen Gie die Tür auf! open the door. jd)reiben Sic ben Briei ab! copy the letter.

52. The most rommon, separable verb-prefixes are:
$\mathfrak{a} \mathfrak{b}$, off , down.

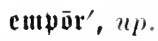
un'ter, down.
ău, on.
entg $\overline{\mathbf{e}}^{\prime} \mathbf{g e n}$, ayainst.
vōr, before.
auf, up, open.
fort, away.
wẹ̆, away.
aus, out.
wit, with, along.
wicber, again.
bei, by.
nâấ), after.
zin, to.
$\boldsymbol{D a} \overline{\mathfrak{a}}, \boldsymbol{d} \bar{a} \mathbf{r}$, there.
nie'ber, down.
zurïßt', back.
ein, in, into.
šb, over.
зијаш'men, together. 
Simple adverbs, adjectives, or even nouns may also become separable prefixes, as:

haus'halten, to keep house; rein'madyen, to clean.

53. 5iin and her - J̧in (thither, there) and her (hither, here) are frequently used alone as prefixes, as: Gin'gehen, to go there; her'fommen, to come from.

\section{Wo gehen Gic hin? Where are you going?}

$\mathfrak{B o}$ fommen Sic hēr? Where do you come from?

(1) They occur more frequently, however, added to another prefix, as: hinab'gehen, to go down; herein'fommen, to come in. In this case hin conveys the idea of motion away from the speaker, her implies motion towards the speaker, as:

Soummen Sie hĕrein'! Come in. (The speaker being inside.)

fiommen Sie hčrnus! Come out. (The speaker being outside.)

(błehen Sie hincin'! Go in. (The speaker being outside.)

(bchen Sie hĭuna: Go out. (The speaker being inside.)

(2) Note, however, that the preposition must not be omitted, even though it contains the same meaning as the prefix, as:

Saf ging in ben Garten hittein, I went into the garden.

Er trat aus dem Sauje heraus, he came out of the house.

In these clauses the prefix could be omitted, but not the preposition. Thus it often happens that a separable prefix with hin or her cannot be translated' into English.

(3) Where no preposition is used in English, but simply an adverb, the latter becomes in German a separable prefix:

(Fr fiel bie $\mathfrak{T} r e p p e ~ \mathfrak{h i n a b}$, he fell down stairs. Sie ging bie Straß̧e hinauf, she went up the street.

Nore. To ascertain the verb, in a sentence with a separable prefix, 
the prefix must be placed before the verb; thus, in the clause in mane bas $\mathfrak{F e n f t e r}$ auf, the verb is aufmade. For convenience a separable prefix is indicated in the vocabularies by a hyphen, as: auf $\mathbf{m a d} \mathfrak{m} \boldsymbol{n}, t o$ open, or the principal parts of the verb are given, as: aus'gehen, giug aus, iît ausgegangen, to go out.

\section{VOCABULARY}

die Fen'iterbanf, "e, the windowsill.

Die $\Omega \ddot{i i}^{\prime} d \mathfrak{e},-\mathfrak{n}$, the kitchen. die $\mathfrak{T r e p}^{\prime} \mathfrak{p c},-\mathrm{n}$, the stairs, steps. trēten, trāt, ijt getrēten, (tritt), to step. hincin'trēten, trāt hinein, ijt hineiı'= getrēten, to step in, enter.

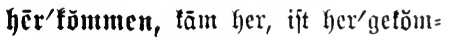

men, to come from.

fŏrt'fein, war fŏrt, ift iŏrt'getwejen,

to be away.

un'tergehen, ging un'ter, ift un'ter= gegantgen, to go under, set.

mit'nehmen, nafm mit, mit'genom= men, to take along.

Dãa $\overline{\mathfrak{a}}^{\prime} \mathfrak{b l e i b e n , ~ b l i e b ~} \delta \bar{a}$, ijt $\delta \bar{a}^{\prime} g e b l i e b e n$, to stay there. heim'bleiben, blieb heim, ijt heim'ge= blieben, to stay at home.

auj'îtehen, jtand auf, ijt auj'gejtan= sent, to get up.

fehen, fah, gejehen, (jieht), to see. heben, hob, gehoben, to lift. auf'hēben, hōb auf, auf'gehōben, to lift up.

tlopfen, to knock. $\mathfrak{z} \mathfrak{u}=\mathfrak{m a d j e n , ~ t o ~ s h u t . ~}$ ăı=bellen, to bark at. lujtig, merry, merrily.

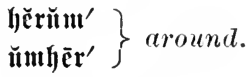
zurï̈', back. binten, behind, at the back. himun'ter, down.

\section{READING EXERCISE}

Max flopft, und ber Sater ruft: „Jeerein!“ (come in.) Max madht bie Tïr auf und tritt in bas Bimmer hinein. Der Bater

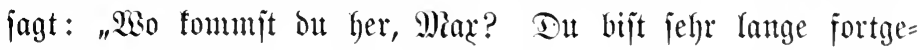
mejen. Die Eonne geht juon unter, uno es wirb ounfel." Max antwortet: "Sard hat midh nadh seanje mitgenommen, uno idh) bin ju lange bageblieben." "Jit bein Bruber mitgegangen?" fragt ber $\mathfrak{B a t e r}$. "Miein," antwortet Max, "er ijt heimgeblieben." 
Miax jhreibt jeine 9 (ufgabe ab, benn jie war jhledht gejdrieben. Sn bem Zimmer wirb es warm, und ber Sater jteht auj und mad)t das Fenjter auf. Dann geht ber Sater hinaus, bergişt aber bie Tïr jujumadyen. Der J̧und fommt in bas Zimmer herein und furingt ahf (upon) die Fenjterbant hinauj. Daz Fenjter ijt auf, und er bellt einen Miann an. Er fällt aus dem Jenjter linaus. Er fällt hinab. Niax ipringt auf uno jieht himunter. Ser Şund jtelht auf und läuft hinten in bie Süche herein. Die Miutter aber jagt ihn aus oer Siithe hinaus. Er läuft bie Treppe hinauf. Max hebt ihn auf uno trägt ihn in

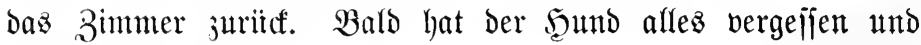
fpringt lujtig herum.

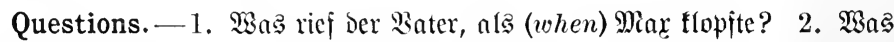
madyte Miax Daum? 3. Was fragte Der Bater? 4. Was hatte farl mit Miax gemadht? 5. Sar ber Brntoer mitgegangen? 6. Waa madfte Max

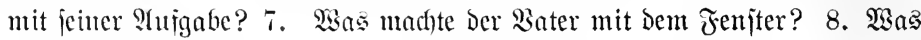

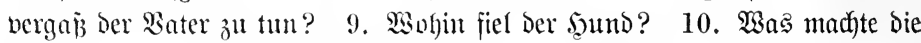

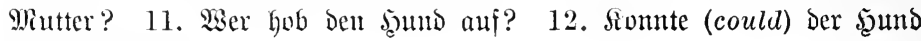
herumpringen?

\section{DRILL}

A. Conjugate: idh nehme die Edyweiter mit; idh hebe Den geuno auf; id bin bageblieben; id war hinabgefallen; id merbe aufitelen.

B. Give past and perfect tense of: idh jtehe auf, er geht fort, wir bleiben ba, bie Eonne geht unter, ber Şund fpringt herum, der Bater nimmt midh mit.

\section{WRITTEN EXERCISE}

1. Open the door and shut the window. 2. He opened the door and came into the room. 3. I said: "Where do you come 
from, Mr. Smith?" 4. Mr. Smith had been away a long time. 5. The sun has set; we have stayed too long. 6. Will you go along? No, I shall stay at home. 7. Copy this exercise, Max; it is badly written. S. Get up and shut the window. It is cold in the room. 9. He had forgotten to shut the window. 10. Do not forget to open the door. 11. He lifted the child up and carried it lack into the room. 12. I knocked, and she called: "Come in!" 13. The mother chased the child out of the kitchen. 14. He entered the room and closed the door. 15. She has copied the letter. 16. The dog barked at me, and I chased him out; but he will soon come back.

\section{LESSON XX}

\section{Declension of Adjectives.}

(1) Adjectives in the predicate, or used as adverbs, are not declined, as :

\section{Der Miann ït fleip̧ig, cr arbeitet gut.}

The man is diligent, he works well.

(2) An adjective standing before a noun, or in place of a noun, is declined. This declension is 'strong' or 'ueal', according to circumstances.

55. Strong Declension of Adjectives. - An adjective is declined 'strong' when no ber or cilt word with grammatical ending precedes it. - For 'ber words' see Lesson XI, 27, 1, 2; for 'ein words', Lesson XII, 30, 5 .

(1) The declension is the same as that of bicjer, excepting that in the genitive singular, masculine and neuter, the weak form $-\mathfrak{c n}$ is used: 


\section{Singular}

Masculine. dear brother.

Nom. lie'ber Bruber.

Gen.

Dat. Ace. lieben Bruberz. liebem Bruber. lieben Bruber.
Feminine.

good mother. gu'te Mutter. guter Mutter. guter Mutter. gute Mutter.

\section{Plural}

Nom. liebe Brüber. Gen. lieber Brilber. Dat. lieben Brübern. Acc. liebe Brüber.

\section{gute Mütter.} guter Mütter. guten Müttern. gute Mütter.
Neuter.

little child. flei'neş $\Re$ ind. fleinen Rindez. fleinem $\Omega$ inde. fleines Rind.

\section{ILLUSTRATIONS}

Er gab fleinen $\Omega$ indern Beld, he gave money to little children. Die $\Re$ inder guter Mütter, the children of good mothers.

a. Two or more adjectives before a noun are all declined alike:

guter lieber Freund, good dear friend.

licbes fleines Sind, dear little child.

Note. - In the dative singular, masculine and neuter, however, all but the first adjective are sometimes declined weak: mit langem weinen $B$ art, with long while beard.

b. Adjectives ending in unaccented $\mathfrak{c l}, \mathfrak{c} \mathfrak{n}, \mathfrak{c r}$ drop the $\mathfrak{e}$ of the stem when inflected:

oun'fle Bimmer, dark rooms (bun'fel, 'dark').

hei'tre Sinder, cheerful children (hei'ter, 'cheerful').

c. hod, high, drops the c, when inflected:

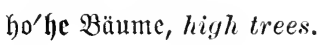

d. Adjectives formed from names of towns are without inflection, ending always in $\mathfrak{c r}$, and are written with a capital:

Berli'ner Straß̉en, Berlin streets.

Reunor'fer Beitungen, New York papers. 
$e$. Participles, when used as adjectives, are inflected as such:

gelieb'ter Freund, beloved friend.

zerbrod'ene (bläjer, broken glasses.

\section{VOCABULARY}

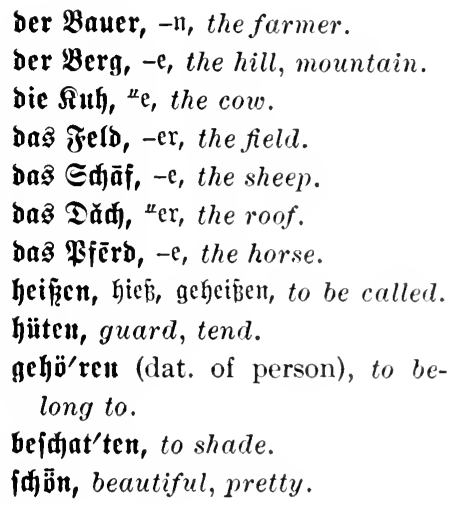

\section{READING EXERCISE}

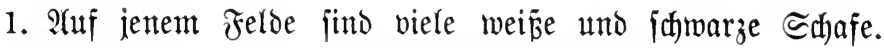
2. Da jind jehn weiß̄e und jechs jumarze Echaje. 3. Atud

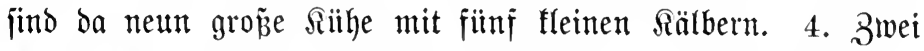

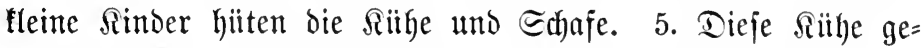
hören fleiß̈igen reidhen Bauern. 6. Feidhe Bauern wohnen in

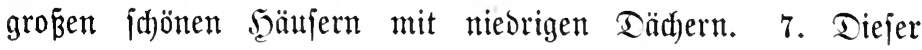
Bauter hat fect)s jüöne Fĩerbe. 8. Mit jwei fdjönen Biferben arbeitet er jetzt auf bem Felbe 9. (Fr hat autd) jwei gute Sunde. 10. (Sejtern verfanjte er jieben junge Sälber. 11. Er ijt ber $\mathfrak{B a t e r}$ vieler Sinder. 12. Er hat vier groß̉e Söhne und brei fleine Tönter. 13. Die Söhne fint fleip̈ig uno arbeiten 
gut. 14. Sn fleinen Dörjern findet man immer viele Sinder. 15. In biejem Dorje jind viele tleine Sinder in ber Erhule. 16. Das Dorf heip̈t Tieubprif. 17. Tieuborjer Bauern haben

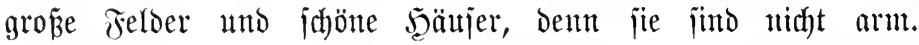
18. Şohe Bäume bejaatten Meuborf, und in ber Ferne jieht man holye Berge.

Questions. - 1. Wie viele weiße und wie vicle idfwarze Erfafe fint auf

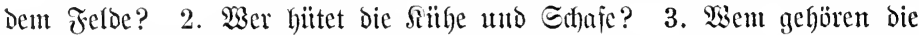
Siithe und Schafe? 4. Waas hat Der Bauter verfauft? 5. WBie viele Rinder hat er? 6. Wie fint bie Söhne? 7. Was haben Meudorfer Bauern? 8. $\mathfrak{i a g}$ jieft man in der Ferne?

\section{DRILL}

A. Decline in the singular and plural: fleißziger Sohn; Hleine

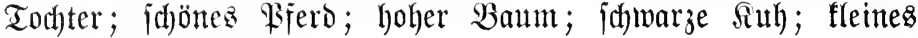
§alb; dunfles 3immer.

B. Translate: little horse; little horses; good man; good men; of good men; to good men; big calf; brown cows; of brown cows; of old women; low roofs; of rich farmers.

C. Name the 'Der words' and the 'ein words.'

\section{WRITTEN EXERCISE}

1. How many black sheep are on that field? Only three black, but nine white sheep. 2. How many cows has the farmer? He has only five big cows, but he has three little

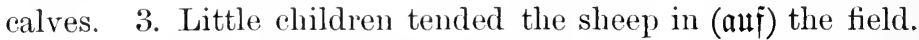
4. The sheep belonged to poor farmers. 5. Poor farmers live in small houses. 6. They are the children of poor farmers. 7. In large villages [there] are always very many large dogs. 8. How many little children are in the school? Only ten little children, but five big children are working on the field. 9. Do you see 
high trees in the distance? No, I see only high mountains. 10. Good dog, come here (her). 11. Little child, what is (use heifien) your name? Hy name is Fritz. 12. These children are German children; they talk German. They are Berlin children.

\section{LESSON XXI}

56. Weak Declension of Adjectives. - An adjective standing before or in place of a nom is declined 'weuk', when preceded by a 'Der word' (ber, biejer, jener, jeber, weldher, mand)er, foldyer).

(1) In the weak declension the nominative singular of all three genders, and the accusative singular of the feminine and neuter genders, have the ending $-\mathfrak{c}$. All other cases (singular and plural) have $-\mathfrak{c}$.

\section{Singular}

Masculine.

the old man.

Nom. der al'te Mann.

Gen. dez alten Mannes.

Dat. dem alten Minn.

Ace. ben alten Maum.
Feminine.

the handsome woman. the young horse. die frö̈'ne frau. das jun'ge Fiferd. der f(f)̈̈nen j̃rau. Des jungen Pferdes.

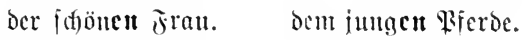
bic ficuöne Trau. das junge Ffero.

\section{PIIRII,}

Nom. bie alten Miämer. die f(t)önen jranen. Die jungen Piferde. Gen. der alten Miänter. ocr f(d)önen Franen. Der jungen Pficroc. Dat. den alten Mä̈nern. Den j(t)önen jrauen. Den jungen Pifersen. Ace. bie alten Miänner. die f(f)önen Trunen. Die inngen

Likewise: Diejer alte Miann, weldhe jöböne Fran, mand)e junge Piero. 


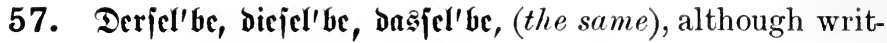
ten as one word, inflect both ber and jelbe, like any other adjective with the definite article:

bicjel'beu Biidfer, the same books.

baz Rind besiel'ben Mannez, the same man's child.

(1) Derfelbe is often used as a substitute for a personal or demonstrative pronoun:

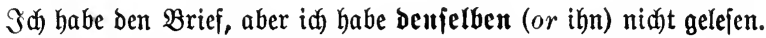

I have the letter, but I have not read (the same) it.

58. The English words 'one', 'ones', standing after an adjective and referring to a preceding noun, are expressed in German only by the inflection of the adjective, as:

Şier find bie neuen Büdder, ba jind bie alten.

Here are the new books, there are the old ones.

Daz alte Şauz mar größ̈er alz daz neue,

The old house was bigger than the new one.

\section{VOCABULARY}

Der Beii'tzer, 一, the owner.

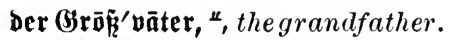

Der Gin' $^{\prime} \mathrm{fl}$, , the grandson.

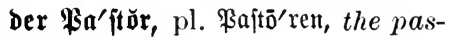

tor, minister.

bie Milld, the milk.

hei'raten, to marry.

frifá, fresh.

neu, new.

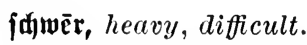

hitbid, handsome, pretty.

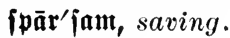

tōt, dead.

ję' $\mathfrak{i g}$ (adj.), present.

hin'ter (gov. dat. when no motion

is implied towards object of preposition), behind. băfīitr', for it.

\section{READING EXERCISE}

1. Die hohen Bäume bei bem alten Seauje bejahatten das ganje Şaus. 2. Dasjelbe ift fehr alt. 3. Sn bemjelben wohnt ber reidge alte Bauer Edymibt. 4. Fhm gehören bie idönen Rühe auf Dem großen Felde. 5. Er verfauft die frifche Milld 
Derjelben in Der gropent Stabt uno befommt jafmeres (much) Beld bafïr. 6. Sein Bater hat bas alte Şaus gebaut uno bie jäönen Bäume gepflanjt. 7. Derjelbe wurbe jehr reid, benn er war fehr jparjam und arbeitete fleip̈ig. 8. Der alte Mann ijt jajon lange tot. 9. Der Eohn Desijelben ijt ber jetsige Bejitzer. 10. Die brei fleinen Sinter in Dem jubönen (barten hinter bem alten Saalje jüts jeine, Enfel. 11. Seine Todyter war jehr hïbid) und heiratete ben jungen Fajtor bez fleinen Dorjez. 12. Ifber er jtarb frith, und jeine junge fraut wohnt mit ben fleinen Simbern bei (with) bem alten Bater. 13. Der alte (bropibater liebt bie fleinen Simber, und jie rieben ben alten Sropipater. 14. Er lyat bas neue $\mathfrak{G} a u z$ da fiir jie gebaut.

Questions. - 1. Wer wohnt in bem alten Şauje? 2. জSem gefören

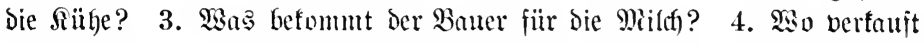

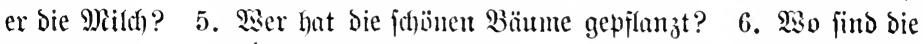

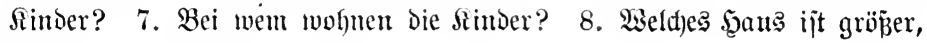
Daz alte ober bas neue?

\section{DRILL}

A. Decline in the singular and plural: biejer hohe $\mathfrak{B a u m}$; weldye groß̉e Staot; mandyez alte Şauz; jenter reiche Bauter; bie gutte Frau; baz nette Buth); Derjelbe Mann; Dasjelbe Pifero.

B. Translate: of the rich farmer; rich farmers; the rich farmers; the young horse; young horses; of the young horses; good milk; the good milk; this new house; these new houses; which little child; of which little child; little children; of these little children.

\section{WRITTEN EXERCISE}

1. This old house belongs to that old farmer. 2. He is the owner of those fine cows. 3. Who built the old house? The father of the present owner. 4. He is also the owner of this 
beautiful garden. 5. These three little children are his grandsons. 6. They are playing upon the large field behind the old house. 7 . They do not live in the large city, but in this little village. 8 . The old grandfather planted the beautiful trees. 9. Now the trces are high and shade the whole house. 10. The beautiful daughter of the old farmer married the young pastor. 11. They live with the rich old grand father in that beautiful large house. 12. The new house is large, the old one is small. 13. This young woman is the mother of these three little children. 14. Where is the father? He is dead; her present husband (Mann) is the pastor of this little village.

\section{LESSON XXII}

59. Mixed (weak and strong) Declension of Adjectives. - An adjective preceded by an 'ein word' $(\$ 30,5)$ is declined strong in the nominative singular masculine and neuter, and also in the accusative neuter, but weak in all other cases, thus: mein guter Bater, but meine guten Bater.

(1) The reason for this is apparent. The 'ein words' have no grammatical endings in the nominative masculine, and nominative and accusative neuter, hence the adjective is given the full grammatical ending; that is to say, is declined strong in these cases. In the other cases the 'ein words' are declined like biefer, and consequently the adjective has weak endings, as after the 'Der words.'

\section{Singular}

Masculine.

my dear brother.

N. mein lie'ber Bruber.

G. meinez lieben $\mathfrak{B r u b e r s . ~ u n i e r e r ~ g u t e n ~ M u t t e r . ~}$

D. meinem lieben Bruber. unjerer guten Mutter. A. meinen lieben Bruber. unjere gute Mutter. fein gutes アind.
Neuter. no good child. fein $g \mathfrak{u}^{\prime}$ tes $\Omega$ indo. feinez guten $\Omega$ indez. feinem guter $\Omega$ inbe. 
Plutal

N. meine lieben Britber. unfere guten Mütter. feine guten Rinder. G. meiner lieben Brüber. unjerer guten Mütter. feiner guten $\Re$ inder. D. meinen lieben Brildern. unjeren guten Müttern. feinen guten Rindern. A. meine lieben $\mathfrak{B}$ rüber. uniere guten Mütter. feine guten $\Re$ inder. Likewise: ein gutcr Mann, einez guten Mannes, etc.

60. Summary of Rules for the declension of Adjectives:

(1) Adjectives standing before nouns, or in place of nouns, are declined strong (like oiejer), if not precerled by a ' $\mathbf{D e r}$ word' or by an inflected form of an 'cin word'.

(2) If preceded by a ' $\boldsymbol{b c r}$ word' or by an inflected form of an 'cin word' the adjective is declined weak; hence:

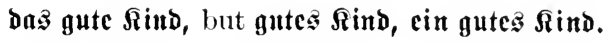

\section{VOCABULARY}

Der $(\mathbb{F} / \mathfrak{j l},-$, the donkey.

ber Saft, "te, the sack.

ber Mitifent, 一, the back.

ber $\Re$ ămĕrāō', -en, the comrade.

Der $\Re$ id

ber Färber, 一, the dyer.

Der Sandiduhf, -e, the glove.

dic @trā $\tilde{e} \mathfrak{c},-\mathfrak{n}$, the street.

bic Şand, "e, the hand.

die Farbe, $-\mathfrak{n}$, the color, dye.

dic Briflc, -nt, the spectacles.

bas Ticr, -e, the animal.

treiben, trieb, getrieben, to drive.

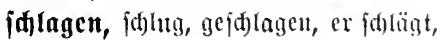

to beat.

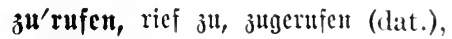
to call to. bejeh'len, bejahl, befohlen, er befiehlt, (dat.), to command, order.

cmpor'hălten, hielt empor, emporge= hălten, to hold up.

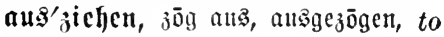
take off, pull off?.

aui'jezsen, to put on.

er tann, he can.

hart'heriti\}, hard-hearted.

gut'beroig, kind-hearted.

cn!n, narrow.

lautg' 'jăm, slow, slowly.

id)nell, quick, quickly.

redt, right.

burrd) (prep. ace.), through.

bód), yet, after all, anyway (used

for emphasis). 


\section{Kameraden.}

Ein harthergiger $\mathfrak{B a u e r}$ trieb einen alten Ejel mit zwei

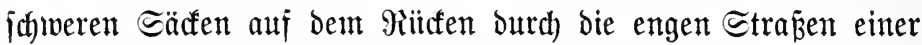
fleinen Stadt. Der alte Ejel ging Dem hartherzigen Bauer ju langjam, aljo juhlug er bas arme Tier mit einem bicfen Stodfe. Fin gutherjiger Mann jah ez und rief dem hartherzigen $\mathfrak{B a u e r}$ zu: "Shlagen Sie bodh $\Im$ hr armez Tier nidht, ez ijt alt uno fann nidht idneller geben!" "Sh! lieber Seerr!" riej ber hart= herzige $\mathfrak{B a u e r}$ zuritcf. "Daz ijt bod jđön, mein alter Ejel hat aljo hier einen guten Sameraben gejunden."

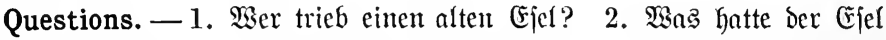
auf dem Rüufen? 3. WSie waren bie Straß̃en? 4. Wie ging der alte Ejel? 5. Wan madte der Bauer mit bem Stofe? 6. Wher jah ę alles?

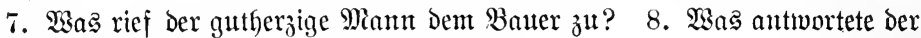
Bauer? 9. Erzählen Sie Dicje (biej(d)idfte!

\section{Eine fhrwarze Gand.}

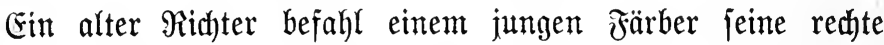
Şand emporzuhalten. Der junge Färber hatte mit idjwarzer Farbe gearbeitet, aljo waren jeine Seände ganj iajwarj. "Biehen Sie Ghre jamarzen Şanbjhuhe auz!" rief ber alte Ridjter bem

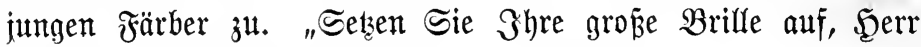
Ridfter!" antwortete idnell ber junge Färber.

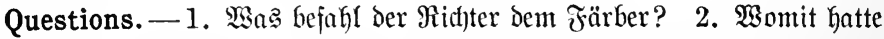
Der Färber gearbeitet? 3. Wie warent bie Şände bes jungen Färberæ?

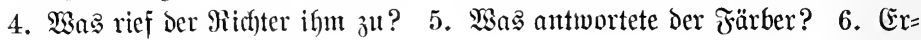
zähten Sie bieje (bejofidgte!

\section{DRILL}

Decline: ein hartherziger Bater; jeine idwarze Şand; mein

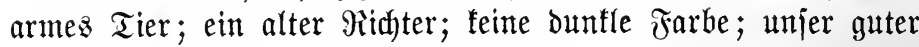
Ejel; Der liebe $\mathfrak{B n t b e r ; ~ b i e ~ g u t e ~ S d h m e j t e r ; ~ d i e j e s ~ g u t e ~ S i n o . ~}$ 
B. Translate: my new book; my new books; his little brother; to his little brother; of her little children; no little child; no little children; your good father; of your good father; his dear mother; to his dear mother; this little child; my little child; good animal; this good animal.

\section{WRITTEN EXERCISE}

1. His kind-hearted father never beats his old animals. 2. An old donkey had two heavy sacks on his back. 3. The streets of this little town are very narrow. 4. This good donkey is an old animal, therefore he cannot go faster. 5. This old animal has found a good friend. 6. A hard-hearted man was beating a poor old donkey with a thick stick. $\tau$. The old judge ordered the young dyer to hold up his right hand. 8. An old judge put on his big spectacles. 9. My right hand is black, for I have been working with black colors. 10. Take off your new gloves; they are becoming very black. 11. Put on your old spectacles. 12. His little brother and your big brother are my good comrades. 13. Her little sister is a good child. 14. His little children are good children. 15. Our new house is not big enough. 16. The rooms of our new house are too small.

\section{LESSON XXIII}

61. Adjectives used as Nouns. - Adjectives are freely used as nouns, being still declined as adjectives though beginning with a capital,as:

Der $\mathfrak{A} \mathfrak{Y}^{\prime}$ te, the old man.

ein $\mathfrak{A} \mathfrak{l}^{\prime} \mathrm{ter}$, an old man.

eine $\mathfrak{A} \mathfrak{l}^{\prime}$ te, an old woman. daz $\left(\bar{u}^{\prime}\right.$ te, the good. viel $\$ u^{\prime}$ tes, much good. bie $\mathfrak{B} \ddot{\mathrm{o}}\{\mathfrak{i} n$, the wicked (people). 
(1) Participles may likewise be used as nouns:

дав (bejdric'bene, what has been written.

der Belieb'te, the beloved one.

ein Belieb'ter, a beloved one.

(2) A few nouns, originally adjectives or participles, are declined like adjectives and are usually called adjectivenouns.

The more frequent are:

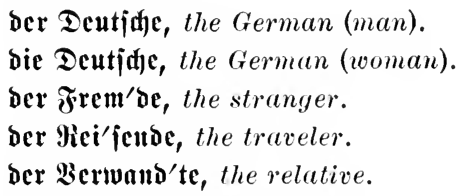

And (strong) ein Dentjuger; cin Frember; mein Bermanster.

SingtLaR

Plural

N. Der Deutide, the German (man). Dic Deutidjel, the Germans.

G. Des Deutidnen, of the German. Der Deutjacn, of the Germans.

D. bem Deutjden, to the German. Den Deutidjen, to the Germans.

A. Den Deutidjen, the German: Die Deutiden, the Germans.

62. In German the adjective is not placed (as often in English) before the 'ein or ber word': meine beiben Sände, both my hands: Die halbe Etabt, half the town.

Note. $-\mathfrak{a} \mathfrak{f}$ forms an exception and generally remains uninflected, as: afl mein bield, all my money; all bie $2 \mathrm{en}$ 'te, all the people.

63. 'Cint words' used as Adjectives or Nouns.

(1) An 'ein word' preceded by a 'Der word' is declined weak, like an ordinary adjective:

Id) habe zwei Büdjer, bas eine ift neu, I have two books, the one is new. Seter ift mein $\mathfrak{B u}(\mathfrak{b})$, da ift baß $\mathfrak{J h r e , ~ h e r e ~ i s ~ m y ~ b o o k , ~ t h e r e ~ i s ~ y o u r s . ~}$ 
(2) An 'ein word', when no noun follows, and no 'ber word' precedes, is declined strong, like any ordinary adjective, as:

(Eites (or einz) meiner Büffer, one of my books.

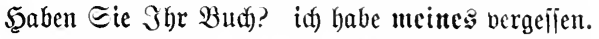
Have you your book? I have forgotten mine.

(3) Note that the English so-called possessive pronouns (mine, thine, yours, ete.), differ in German from the possessive adjectives only by having the full ending in all ases, if not preceded by ber, as:

Эa) habe meines, or bas meine, I have mine (Bud()).

Sie haben $\mathfrak{J h r e s , ~ o r ~ b a z ~} \Im$ hre, you have yours (Budd)).

Err hat ifren, or ben ihren, he has leers (Brief).

\section{VOCABULARY}

der $\mathfrak{A}$ tue $\mathbf{r i f} \overline{\mathfrak{a}}^{\prime} \mathfrak{n e r}$, , the American. ber Mame, -n, the name.

ber $\mathfrak{B e j t e n ,}$ the West. die Fănt'ílie, $-\mathfrak{n}$, the family. Die $\mathfrak{B i}^{\prime} \mathfrak{b} \mathfrak{d},-\mathfrak{n}$, the bible. $\mathfrak{b a g} \mathfrak{B} \mathfrak{a}^{\prime}$ terland $\mathbf{d}$, the fatherland. Das $\mathfrak{B o l f}, "$ "r, the people, nation. bas $\mathfrak{Q} \mathfrak{e b e n}$, , the life. $\mathfrak{A} \mathfrak{m} \overline{\mathbf{e}} ' \mathbf{r i f a ̄}$, America.
Dic (EIterit, the parents. Die (Grojeltern, the grandparents. Sïbdeutja'lăno, south Germany. $\mathfrak{a} \mathfrak{i} \mathfrak{i}=\mathbf{i d}) \mathbf{c i b e n}$, to write down. brā̄y, honest, good. fern, distant, far. Icidyt, easy, easily. nād) (prep. gov. dat.), to; toward; after.

\section{READING EXERCISE}

1. Mein guter alter (5ropionter war cin Teuticher. 2. Meine

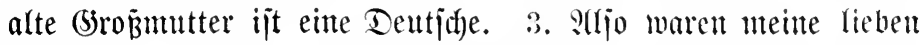

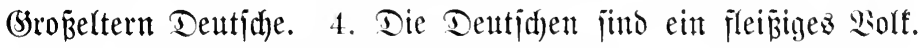
5. Siele Deutidge jinto nad) S(merifa gefommen uno haben da ein neues Batertand gefunden, aber nod) immer lieben jie ihr altes. 6. Shre vielen Sintor werden Smerifaner, aber jie

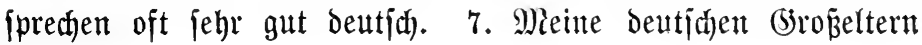


famen aus (from) einer fleinen Stabt in Sïbdeutidaland. 8. Sie reiften nad) diejem fabönen ?ande und tauften ein Hleines

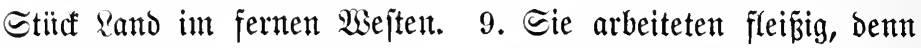
mein braver (3rojpoater war ein guter beutjher Bauter. 10. Bald

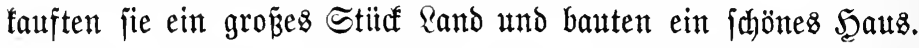
11. Shre beutfihen Berwantsten famen autd nach âmerifa uno fauften Pand. 12. Sie hatten alle jehr viele Sinber, und jo

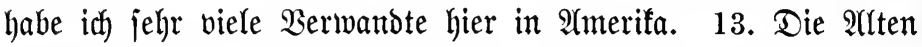
iprechen Deutich, aber bie Güngeren haben ez vergejijen. 14. Эah habe ein altes Buch meines guten (Brop̉naters; es ijt eine alte beutjache $\mathfrak{B i b e l . ~ 1 5 . ~ D a r i n ~ j t e h e n ~ a l l e ~ \Re a m e n ~ b e r ~ g a n z e n ~} \mathfrak{F a}=$ milie aufgejhrieben. 16. Das (bejhriebene ift nidht immer leidgt zu Yejen. 17. Stud habe idh zlwei alte Bilder, daz eine ijt ein jäönes $\mathfrak{B i l}$ meiner häbjhen (Sroṕmutter. 18. Sie hat viel Butez in ifrem langen Reben getan (done). 19. Das Gite Gleibt, aber das $\mathfrak{B}$ öje jtirbt. 20. Nidht Geber hat joldje braven

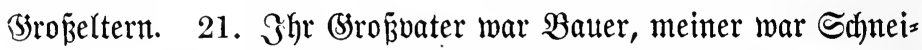
ber. 22. Ghre Bropeltern waren Deutjhe, die meinen waren :meritanter.

Questions. - 1. Waa für ein $\mathfrak{B}$ off find bie Dentidjen? 2. Wofin finto viele Deutijhe gefommen? 3. Wag haben fie bort gefunden? 4. $\mathfrak{W a}$ licben fie aber nod) immer? 5. Was werben ifgre Simber hier in $\mathfrak{A m e r i f a}$ ?

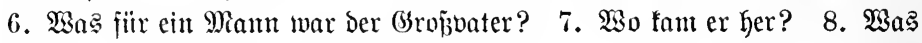

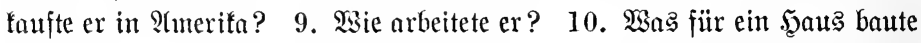

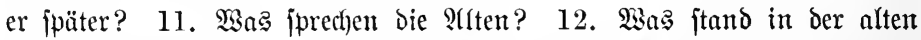
Bibel aufgeidrieben? 13. Weijen Bild war bas eine? 14. Was hatte

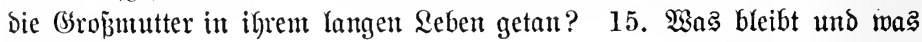
ftirbt?

\section{DRILL}

A. Decline in the singular and plural: Kein böjer Mann; unfere fleine Sdywejter; fein neuez Bud); $\mathfrak{G h r}$ guter $\mathfrak{B r u b e r}$; 
ihre alte (5roşmutter; mein jhönes Sind; biejer gute Miann; das neue Budh; biejer lange Brief; gute Mutter; bie alte Bibel.

B. Translate: of my old father; to lis little child; her good sister; these good sisters; my new books; little brother; of my old mother; to our honest German; this old man; old man; of old men; good women.

C. Decline in the singular and plural: weldher Teutjd); fein Teutfder; Der Berwandte; mein Berwanter ; biejer Frembe; unjer frember.

\section{WRITTEN EXERCISE}

1. My old grandfather came from a large village in Germany. 2. He and his good wife travelled to (nadf) America. 3. He was a poor man, but he liad a rich uncle. 4. This rich uncle lived in a big house. 5. His little children loved my good grandfather. 6. His rich uncle gave him money. 7 . He came to this beautiful country. 8. Both my grandparents are Germans. 9. My German grandparents were poor but industrious farmers in South Germany. 10. They had only a small piece [of] land, two good cows, and an old horse. 11. They had a large family. 12. I have a very old picture of my honest grandfather. 13. He was a handsome man. 14. His good wife was an industrious woman. 15. She and her little children worked hard. 16. My grandfather is a good American, but he loves his old fatherland. 17. He has many relatives in Germany. 18. The one lrother also came to America. 19. My good old grandfather has seen mucli evil, but also much good in his long life. 20. This is his pieture, that is hers. 21. Both these pictures are mine. 22. You have her picture, and I have his. 


\section{LESSON XXIV}

64. Comparison of Adjectives. - As in English, adjectives add $\mathfrak{c r}$ to form the comparative; cit or it to form the superlative. Monosyllables in $\mathfrak{a}, \mathfrak{D}, \mathfrak{a t}$ generally take the umlaut:

Positive

reidf), rich.

ărm, poor.

ftătf, strong.
Comparative

reidjer, richer. ärmer, poorer. ftärfer, stronger.
Superlative

ber reidfite, the richest. Der ärmite, the poorest. ber jtärfite, the strongest. also: bie (baz) reichjte, bie (bas) ärmpte, bie (baz) ftärfjte, etc.

(1) Some do not have the umlaut, as:
voll, full.
voller, fuller.
ber volfite, the fullest.
Iaut, loud.
Iauter, louder.
ber lautite, the loudest.

(2) Some are irregular, as:

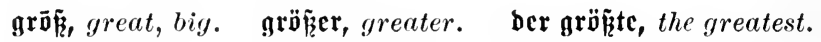

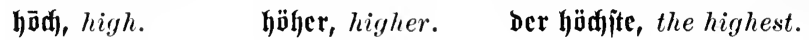

nahe, near. näher, nearer. der nädjite, the nearest.

(3) Some have different stems:
gīit, good.
beijer, better.
Der beitc, the best.
vicl, much.
mehr, more.
ber meifte, the most.

So also the adverb:

germ, gladly. lieber, rather. am liebjten, most gladly.

(4) Adjectives ending in unaccented $\mathfrak{c n}, \mathfrak{c l}, \mathfrak{c r}$ drop the $\mathfrak{c}$ of the stem in the comparative (as in declension):

Dutfel, dark. Dunfler, darker. Der Dunfelite, the darkest. jelten, rare. jeltner, rarer. ber jeltenjte, the rarest. [ful. heiter, cheerful. hcitrer, more cheerful. ber heiterite, the most cheer- 
(5) Comparison is formed without regard to the number of syllables, thus: frei'gebig, yenerous, freigebiger, ber freigebigjte, where in English 'more' and 'most' would be used.

65. Comparatives and superlatives are declined according to the rules for the positive: '

ber är'mere Mann, the poorer man.

ein är'merer Mann, a poorer man.

ber ärm' $\mathfrak{m}^{\prime}$ te $M a n n$, the poorest man.

ftär'fere $\Omega$ inder, stronger children.

bie ftär'fercn $\Omega$ in

66. $\mathfrak{Y}(\mathfrak{Z}$ and $\mathfrak{M i c}$ after Adjectives or Adverbs. - Mie expresses equality, ala inequality. Hence, after a positive, use wie; but, after a comparative, als:

Er ift fo ftarf wie idu, he is as strong as $I$.

Er ift ftürfer als idf), he is stronger than $I$.

67. The Predicate Superlative. - The superlative of an adjective, or of an adverb, in the predicute is formed with $\mathfrak{a m}$, followed by the superlative ending in $\mathfrak{n}$ :

Die Eonne geht am frïhjten im Eommer auf.

The sun rises earliest in summer (compare English, 'at the earliest').

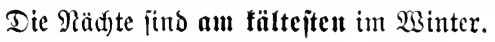

The nights are coldest in winter.

(1) Where in English the article is used with a predicate adjective in the superlative, it can also be so used in German, as:

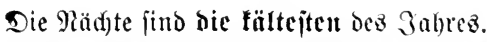

The nights are the coldest of the year.

(2) Adverbial superlatives are formed with $\mathfrak{a m}$, as:

Eie hat ihre 9 (rbeit aut idfled)tejten gemadyt.

She has done her work the worst, or worst. 
a. An adverbial superlative, where no comparison is intended, is also formed with $\mathfrak{a} \mathfrak{u} \mathfrak{i}$ (auf bas), as:

Das Scaus ift auf $\mathfrak{z}$ bejte gebaut.

The house is built in the best manner.

\section{VOCABULARY}

ber $\mathfrak{T} \overline{\mathfrak{n} g},-\mathrm{e}$, the day.

ber $\mathfrak{T u r m ,} "{ }^{\mathrm{e}}$, the steeple, tower.

bie $\Omega i(x) \mathfrak{e},-n$, the church.

bie 3eit, -en, the time.

helfen, half, geholfen, (hilft), dat., to help.

fleiben, to dress. [as.

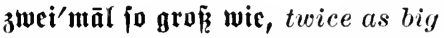
$\mathfrak{e}^{\prime}$ benjo grofiz wie, just as big as. $\mathfrak{w} \overline{\mathbf{e}}^{\prime} \mathfrak{n i g}$, little (in quantity). gern haben (acc.), to be fond of, to like. gern gehelt, to be fond of going. id gehe licber, I would rather go. id) gehe am liebjten, I like best to go.

Iez̧t, last.

autber, other.

\section{READING EXERCISE}

1. Mein $\mathfrak{B r u b e r}$ ijt älter als id), er ijt ber ältejte in ber

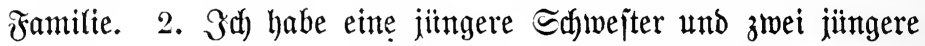

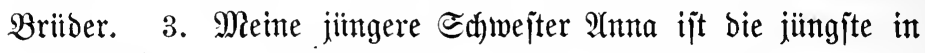
ber Familie. 4. Miein älterer $\mathfrak{B}$ ruber ijt frïher nidht ftarf gemejen, jełst ijt er aber viel jtärfer als idy. 5. Wir mohnen in bem ältejten Şauje ber હtabt. 6. Ea ijt aber am beịten gebaut. 7. Wir haben den größ̈ten (Sarten; unjerer ijt zmeimal fo groß̉ wie bie anderen (5ürten. 8. Die Bäıme jint höher alz bas Seaus, und das Şaus ijt ebenjo hod wie bie Sirche. 9. Die Sirche aber hat feinen Turm. 10. Jm Sommer ijt ez am \{ajönjten bei uns. 11. Die Tage jint Dann am längiten, und man ijt immer braukent. 12. Die neteren Şäujer ber Stabt ftehen viel näher jujammen unb haben viel fleinere (bärten als Die älteren Şäujer. 13. Seerr Schmibt ijt ber reichjte Mann in 
ber Stabt. 14. (Fr lyat bas größ̈te und j(f)önjte Seaus, aber bie meijte Zeit ijt er nidjt ba. 15. Wir haben ign alle jehr gern. 16. Er ijt ber freigebigite Mann und ljilft gern den $\mathfrak{A}$ rmen. 17. $\mathfrak{A}$ m liebjten wohnt er ruhig hier, aber feine Frau reift lieber. 18. Sie reijt gern nadh Tiew York, aber am liebiten nad) Pariz. 19. Sie ift immer aufz bejte gefleibet. 20. Sie ipridgt audh am meijten und am lautejten, er ipricht am menigiten. 21. Şier ijt unjer $\mathfrak{H a} z$ s, ba ijt jeines. 22. Das jeine ijt . Das jajönjte.

Questions. - 1. Eind bie Iage im Eommer fürżer nder länger al’ im Winter? 2. WSaum haben wir ben längiten Tag, im Eommer nocr im Winter? 3. beht bie Eonne früher im Sommer als int Sinter auf?

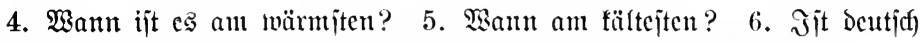
¡dfwerer als englija)? 7 . Sit bicjes 3 immer gröjer als jenes? etc.

\section{DRILL}

A. Compare, with umlaut: franf, warm, falt, jtarf, lang, jung; (without umlaut), neu, lujtig, langjam, bunfel, teuer, froh, ruhig.

B. Form the superlative of the above arljectives as adrerbs.

\section{WRITTEN EXERCISE}

1. Are you older than your brother?' 'Tes, I am older, but my sister is the oldest in our family. 2. My brother is just as large as I, but I am stronger. 3. I am the strongest in the sehool. 4. My elder sister is the most diligent. 5. She works best at home. 6. Our little church has the highest steeple. 7. It is built in the best manner (see $67,(2) a$ ). 8 . It is most beautiful here in summer. 9. My unele is building a larger and better loouse than the old one. 10. Our house is twice as large as his, but his is better built. 11. The other houses are smaller, and the rooms are darker. 12. This is the darkest room in the house. 13. They bave the largest house, but the smallest garden. 14. He helped me (dut.) gladly. 15. She is 
fond of the smallest children and helps them gladly. 16. I would rather go home. 17. Who talks most? 'She talks most, but he talks loudest. 18. (Give me the smaller book. 19. Today is the longest day of the year. 20. The sun rose very early.

\section{LESSON XXV}

\section{REVIEW OF LESSONS XV TO XXIV}

68. 1. What is meant hy the 'finite verb'?

2 . State the rule for the position of the finite verb in independent clauses.

3. Give the following sentence in all the possible word-positions: idf habe gejtern meinen Dufel in ber Stadt gejelyen.

4. Name the coördinating conjunctions. Do they influence the position of the verb?

5. When is fontorn used? when allein?

6. When is 'for' translated by benn? when by fïr? Form two sentences illustrating this.

7. What is meant by 'Normal Oriler'? what by 'Inverted Order'? Form sentences to illustrate this.

69. 1. What is 'ablaut'? What is 'umlaut'?

2. How is the past tense of a strong verb formed? How that of a weak verb? Give three examples of each class of verbs.

3. What are the principal parts of a verb?

4. What verbs change the vowel in the second and third person singular of the present tense? Give two examples.

5. What verbs take umlaut in the second and third person singular of the present tense? Give examples.

70. 1. Name the inseparable verb-prefixes.

2. What idea does the prefix $\mathfrak{z} \mathfrak{e r}$ - convey? what ent-?

3. Which prefix takes the accent, the separable or the inseparable? 
4. Name six separable verb-prefixes.

5. In which tenses do the separable prefixes separate from the verb?

6. Do the verbs with separahle, or those with inseparable verbprefixes take $\mathfrak{g e}$ - to form the past participle? Where does the ge-stand? Give examples.

7. What direction does hin express, what her?

71. 1. What is a transitive, and what an intransitive verb? Give examples.

2. What verbs take $\mathfrak{h a b e n}$ as auxiliary?

3. What verbs take jein? Illustrate by examples.

72. 1. Name the 'ber words'.

2. Why is an adjective following a 'ber word' weak?

3. Name the 'cin words'.

4. When is the adjective following an 'cin word' weak, and when strong? Illustrate by example.

5. Name the weak endings of an adjective.

6. What is meant by 'strong' in regard to adjectives?

7. Why must the adjective be strong when no article modifies the noun?

8. Is the adjective ever uninflected, i.e. without a grammatical ending?

9. Do adjectives used as nouns differ from other inflected arljectives? Give an example of an aljective-nom, and decline it.

10. Give a brief summary of rules for atjective declension, illustrating hy examples. .

11. How are 'ein words' declinert when used as common arljectives?

73. 1. How are adjertives compared?

$\therefore$ What does wie express after an anljective? what als? Illustrate by examples.

3. How is the predieate superlative of an anjeetive or superlative of an adverb formed? Illustrate it in a sentence.

4. How are adjectives declined in the comparative and superlative? 


\section{Qejeitüirfe.}

Note. It is suggested that all the poetic selections in this book be read, memorized, and used for grammatical illustration, without translation, but with an intelligent understanding of all the words and of the sentiment expressed.

\section{Einfehr.*}

Bei einem Wirte wundermilld,

Ba war id jïngit jut (Bajte;

Ein goldner 2 pfel war jein Sdjild

4

$\mathfrak{A} \mathfrak{n}$ einem langen $\mathfrak{2}$ jite.

C̈s war der gute $\mathfrak{A p j e l e l b a u m , ~}$

Bei bem id eingefehret;

Mit jii ß̈er Sojt und frifhem Shaum

8

Şat er mich wohl genähret.

Es famen in fein grïnes Şaนts

Biel leidhtbejdiningte (Säjte;

Sie jprangen frei und hielten ভamaus

12

und jangen auf daz bejte.

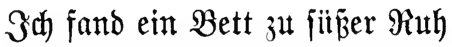

Auf weidhen, griinen Miatten;

Der Wirt, er becfte jelbit mich zu

16

Mit jeinem łiihlen Sdjatten.

Pan fragt' id $\mathfrak{n a d h}$ ber Sdhuldigfeit,

Da idjitttelt' er ben $\mathfrak{B i p f e l}$.

(bejegnet jei er alle Zeit

20 Bon ber $\mathfrak{B u r}$ jel biz zum Sipfel!

Ilfland. (1811.)

* putting up (at an inn). ${ }^{1}$ at an innkeeper's, wonderfully kind. ${ }^{2}$ lately a guest. ${ }^{3}$ sign. ${ }^{4}$ branch. ${ }^{6}$ read : eingefefrt bin, put up; the ending et is poetic (as also in genühret below). ${ }^{7}$ sweet food. - foam (drink) ${ }^{8}$ fed. ${ }^{10}$ light-winged. ${ }^{11}$ freely.(held) had a feast. ${ }^{13}$ rest. ${ }^{14}$ soft. - meadows. ${ }^{15}$ ju=becfen, to cover up. ${ }^{16}$ cool shade. ${ }^{17}$ obligation (here, bill). ${ }^{18}$ shook. - top. ${ }^{19}$ blessed. ${ }^{20}$ root. - to the top 
2. Sorelei.

Эđ̆ weis nicht, waz foll es bebeuten,

$\mathcal{D} \mathfrak{a} \tilde{\mathfrak{B}}$ id) jo traurig bin;

(Fin Märchen auz alten Beiten,

Das fommt mir nicht auts bem હinn.

Die : $\mathfrak{a f t}$ ijt tiifhl, und es ounfelt,

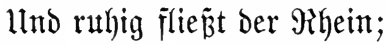

Der Ssipfel bes Bergez funfelt

8

$\mathfrak{I m}$ atbendjontenjidein.

Die jüönjte 马ungiraut jizzet

Dort oben, munderbar, Jhr goldne Bejdmeide blitzet,

12

Sie fämmt ihr goldenez Şar.

Sie fämmt ez mit golbenem Siamme

llnd jingt ein Sied babei;

Daz hat eine munderjame,

i6 (5emaltige Melodei.

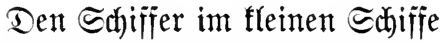

Ergreift ez mit wildem $\mathfrak{B e g}$ :

(Er j(d)aut nidyt bie Felienrifie,

20

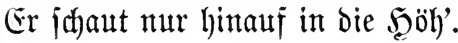

Эa) glaube, bie $\mathfrak{B e f l e n}$ verjahlingen

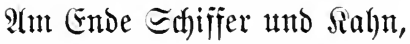

llnt bas hat mit ifrem Eingen

24

Die Porelei getan.

5ुeine. (1823.)

${ }^{1}$ know. - what it means. ${ }^{2}$ that. - sad. ${ }^{3}$ legend. "mind. ${ }^{5}$ grows dark. ${ }^{6}$ flows. ${ }^{7}$ sparkles. ${ }^{8}$ evening sunshine. ${ }^{9}$ maiden. ${ }^{10}$ up yonder. - wonderful. ${ }^{11}$ jewelry. - flashes. ${ }^{12}$ combs. - hair. ${ }^{13}$ comb. ${ }^{14}$ song. - 'there with' i.e. while doing so. ${ }^{15}$ wonderful. ${ }^{16}$ powerful melody. ${ }^{17}$ boatman. ${ }^{18}$ seizes. - pain. ${ }^{19} \mathrm{look}$ at. - reef of rocks. ${ }^{20}$ up (lit. 'upward, in the height'). ${ }^{21}$ waves. - swallow up. ${ }^{22}$ boat. ${ }^{24}$ done. 


\section{3. $\mathfrak{U}_{\text {usgegangert. }}{ }^{1}$}

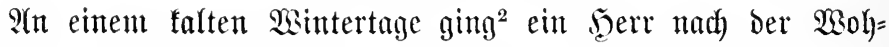
$\mathfrak{n u n g}^{8}$ eines Befanttent ${ }^{4}$ und flintgelte. ${ }^{5}$ Ein Dienjtmäbdhen ${ }^{6}$ madyte bie Tïr auf, und ber Seerr fagte ju ihr: "Jit Seerr

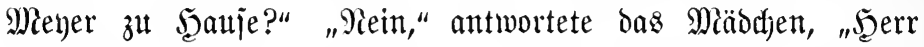
Meyer ijt joeben auzgegangen." "Jit Frau Meyer zu Şauje?" fragte barauf ${ }^{8}$ Der Serr. "Yiein," war bie 9tntwort, "Frau Mielyer ijt nadh ber Stadt gegangen." "(Sut," pagte Der Seerr, "Dann werbe id midh im $\mathfrak{B o h n z i m m e r}{ }^{10}$ hinjetzen ${ }^{11}$ und auf jie warten, ${ }^{12}$ ez ijt falt braunen, und Sie haben woh $\mathfrak{l}^{13}$ ein gutez Feuer!“14 "Daz ijt auch) auzgegangen," jagte baz bumme ${ }^{15}$ Mäschen und madyte die Şatsititre vor feiner Maje

\footnotetext{
${ }^{1}$ gone out. ${ }^{2}$ went. ${ }^{3}$ dwelling. ${ }^{4}$ acquaintance. ${ }^{5}$ rang the bell. ${ }^{6}$ servant-girl. ${ }^{7}$ just. ${ }^{8}$ thereupon, ${ }^{9}$ all right. ${ }^{10}$ sitting-room. ${ }^{11}$ sit down. ${ }^{12}$ wait for her. ${ }^{13}$ probably. ${ }^{14}$ fire. ${ }^{15}$ stupid, ${ }^{16}$ in his face (lit. 'before his nose').
}

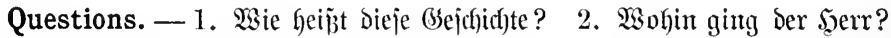

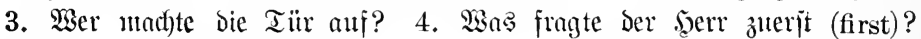

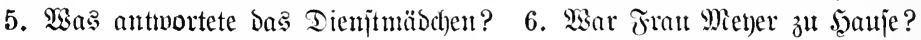
7. Wobin war fie gegangen? 8. Wo swar ein guttes Feuer? 9. Wie war

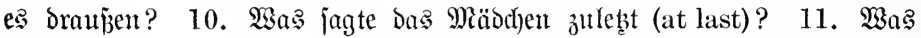

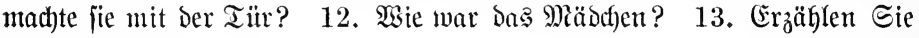
bieje Brejuididte!

\section{Danfbarkeit. ${ }^{1}$}

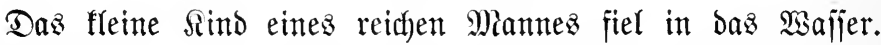
Das Wajjer war tief, ${ }^{2}$ und das arme Sind fonnte ${ }^{8}$ nicht jafmim= men. ${ }^{4}$ Ein armer Miann hatte ez aber gejehen. Er iprang hinein und holte ${ }^{5}$ das Sind herats. Der reidje Sater hatte alles von jeinem Sauje aus gejehen. Gr lief hinju, bantte bem Manne und briidfe ${ }^{9}$ ím etwaz ${ }^{10}$ in bie Seand. Der arme Mann fand aber nadher ${ }^{11}$ nur eine Marf ${ }^{12}$ in ber $\mathfrak{T} a n d$. Er 


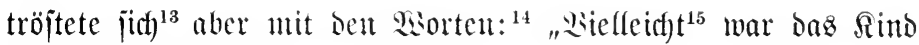
nur eine Mart mert."

${ }^{1}$ gratitude. ${ }^{2}$ deep. ${ }^{3}$ could, ${ }^{4}$ swim. ${ }^{5}$ fetched. ${ }^{6}$ von . . a aus $=$ (out) from. ${ }^{7}$ up. ${ }^{8}$ thanked. ${ }^{9}$ pressed. ${ }^{10}$ something. ${ }^{11}$ afterwards. ${ }^{12}$ mark (twenty-four cents). ${ }^{13}$ consoled himself. ${ }^{14}$ words. ${ }^{15}$ perhaps.

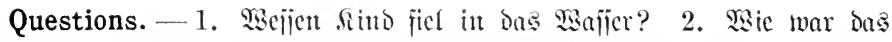

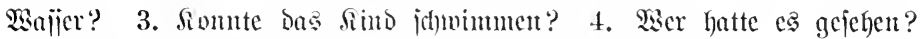
5. Wobin fprang ber Mann. 6. Wag mad)te er mit ben Rinde? 7. Seatte ber Sater es alles geichen? 8. Sias brütfte ber reiche Bater bem armen Mame in bie scants? 9. Mit weld)en Wortent trïjtete ber Mann jidf? 10. Erjählen Eic bicje (bejd)idtete!

\section{LESSON XYVI}

\section{Declension of Nouns.}

There are two declensions of nouns, the strong and the reak. When used of nomns or adjectives, 'strong' does not denote Ablunt, as with verbs, but merely 'strong or rich in endings'; while 'weak' denotes fewer endings. The German noun, whether strong or weak, has comparatively little inflection.

75. Strong Declension. - Masculine and neuter nouns of the strong declension ald $s$ or $\mathfrak{c}$ s to form the genitive singular:

Nom. Der Bater, the futher.

Das Ritio, the child.

Gen. Des Baters, of the futher. des Rittbes, of the child.

(1) Masculine and neuter noums of one syllable take $\mathfrak{c}$ in the dative singular:

bem Mianne, to the man. in be $\mathfrak{5 a n j}$, in the house.

Nore. - This $\mathfrak{e}$ may be omitted, especially in conversation, thus: idf) $\mathfrak{g} \mathfrak{a b} \mathfrak{e s ~}$ dem Miaum. 
(2) Feminine nouns remain unchanged in the singular:

Nom. Dic Miutter, the mother.

Gen. Der Mitter, of the mother. bic Stabt, the town.

ber Stadt, of the town.

(3) The dative plural always ends in $\mathfrak{n}$ :

Deu Mläntern, to the men.

in ben $Z^{\mathfrak{i n m} m e r n, ~ i n ~ t h e ~ r o o m s . ~}$

76. Strong Declension, Three Classes. - Nouns of the strong declension are divided into three classes, according to the formation of the plural: the First Class takes no ending; the Second Class takes $\mathfrak{c}$; the Third Class takes cr.

77. First Class of the Strong Declension. - The nominative plural is the same as the nominative singular, excepting that some nouns require the umlaut in the plural.

(1) To this class belong:

I. All masculine and neuter nouns ending in $\mathfrak{c l}, \mathfrak{c n}, \mathfrak{c r}$, as:

SINGULAR

Der $\mathfrak{B o g e l}$, the bird. ber Barten, the garden. Der $\mathfrak{Q e h r e r}$, the teacher. Das $\mathfrak{F e n j t e r , ~ t h e ~ w i n d o w . ~}$

II. Two feminines:

bie Miutter, the mother. bic Tơdter, the daughter.
Plural

Dic $\mathfrak{B} \ddot{g} g e l$, the birds. Die Gärten, the gardens. bie $\mathfrak{L e h r e r}$, the teachers. bie $\mathfrak{F e n j t e r , ~ t h e ~ w i n d o w s . ~}$

III. Neuters with the prefix $(\mathfrak{G} \mathfrak{c}-$ and the suffix $-\mathfrak{c}$, as: bas $\mathfrak{B J e b i r}^{\prime} \mathfrak{g e}$, the mountain-range. Die $\mathfrak{G e b i r}^{\prime} \mathfrak{g}$, the mountain-ranges. das (Scmä̌l'be, the painting.

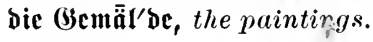

IV. Neuter diminutives in - $\mathfrak{d}) \mathfrak{c}$ and -lein, as:

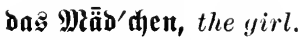
bie Miǟ'd Daß Fräu'lein, the young lady, Miss. bie Frä̆'lein, the young ladies. $\mathfrak{b a z} \mathfrak{S} \mathfrak{a} \mathfrak{u} \mathfrak{z}^{\prime} \mathfrak{d} \mathfrak{e n}$, the cottage. bie $\mathfrak{S} \ddot{\mathfrak{a}} \mathfrak{H} \mathfrak{Z}^{\prime} \mathfrak{d} \mathfrak{e n}$, the cottages. 


\section{Masculine}

Singular

Pleral

Nom. ber $\mathfrak{B}$ ogel, the bird.

bic $\mathfrak{B}$ ögel, the birds.

Gen. Des $\mathfrak{B o g c l s}$, of the bird.

ber $\mathfrak{B}$ ögel, of the birds.

Dat. bem $\mathfrak{B o g e l}$, to the bird.

Den $\mathfrak{B}$ ögeln, to the birds.

Acc. ben $\mathfrak{B o g e l}$, the bird.

bie Bögel, the birds.

\section{Feminine}

Nom. die Mutter, the mother.

bie Mittter, the mothers.

Gen. ber Mitter, of the mother.

ber Mliitter, of the mothers.

Dat. ber Diutter, to the mother.

Acc. Die Miutter, the mother.

Den Mlïttern, to the mothers.

die Miitter, the mothers.

\section{Neuter}

Nom. daz Miäbdid, the girl.

bie Miäbden, the girls.

Gen. bez Mläbdjens, of the girl. ber Miäbden, of the girls. Dat. Dem Mläbden, to the girl. Acc. bå Mläbdien, the girl. ben Mläbden, to the girls. die Mläbd)ent, the girls.

78. Neuter Diminutives. - The endings -dfen and-lein form neuter diminutives, as:

ber Eolyn, the son.

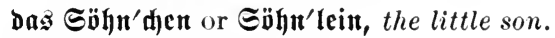

bic $\mathfrak{T} 0$ ')'ter, the daughter.

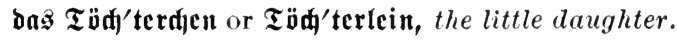

a. Compare in English: man, mannikin; goose, gosling.

(1) These endings are also often used with proper names, as: Fritz'chen, Freddie; Gret'nden, Maggie.

(2) If -dyen or-lein is added to a noun, the stem-vowel (if $\mathfrak{a}$, $\mathfrak{o}, \mathfrak{u})$ takes the umlaut. As diminutives are neuter, Jiäbd)en (from Mago), girl, and Fräu'lein (from Frau), Miss, young $l a d y$, are in the neuter gender, although the diminutive meaning is no longer felt.

Note. - As few of the rules for the formation of the plural of nouns cover the question of umlaut, the plural will be given in the vocabularies as before. 


\section{VOCABULARY}

Der Mialer, -, the painter. Der Sillner, -, the waiter. Der Eng'läntor, 一, the Englishman.

ber $\mathfrak{A}^{\prime}$ bler, -, the eagle.

oer $\mathbf{Q}$ öfifel, 一, the spoon.

Das Meifier, -, the knife.

bas Bäum'd)en, 一, the little tree.

Englato (bas), England.

fütgen, făng, gejŭngen, to sing. fliugen, tlăng̣, getlungen, to sound.

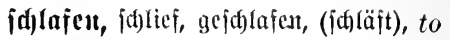
sleep.

unalen, to paint.

vïen (adj.), open.

viele, many.

uัŏd) utid(t), not yet.

$\mathfrak{e}$ gibt (followed by acc.), there $i s$,

there are.

$\mathrm{j} \breve{a}, w h y$, to be sure.

\section{READING EXERCISE}

1. Die Bögel jangen heute frith in unjerem (Sarten, ez flang munberichön. 2. Die Feniter meines Bimmers waren offen, und ich hörte bie Bögel. 3. Die Mäbdhen unto igre Brüber fanden viele \&̈ppel in ben (särten. 4. Die Miitter ber Miäb= dhen waren nicht ba, jie jhliejen noch. 5. Fräulein Braun hat gejungen, fie jingt nod) jhöner als bie Bögel. 6. Ghre Brüber jind Małer, haben Sie igre (Siemälde nod) nidht gejehen? Rein, idh) habe ihre (bemälde nicht gejehen. 7. Ghr $2 a t e r$ und jmei Sntel jind Rehrer, aber bie Sinder fint alle Maler. 8. Sie jind ja bie Enfel meines @anneiders. 9. Zwei (Järtner arbei= teten in Dem (Sarten, jie piflanjten Bäumchen. 10. Dieje (3ärtner wohnen in einem Şäışhen in bem (Sarten. 11. Sie jind beide Engländer. 12. 3it der Bogel da ein Mrbler? Yein,

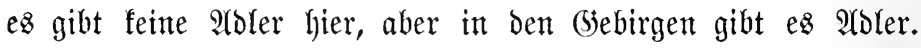

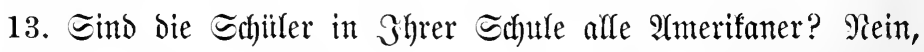
ez gibt auth) einen Engländer ba, aber er ijt jưon jehr lange in T(merifa. 14. Der Siellner (h)läft, er lat unz feine Söffel und Mejijer gegeben. 15. Es gibt bier Sellner genug, aber jie 
ihtafen alle. 16. Es gibt mur eimen Siellner in bem Simmer.

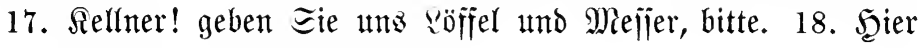
jint ?öffel, aber leine Miejier.

\section{DRILL}

A. Give the singular and plural of all nouns in the Reading Exercise.

B. Form the diminutive of: Der Mann, ber $\Xi \mathfrak{d n e i b e r , ~ b e r ~}$

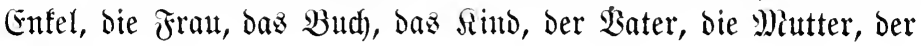
Bruber.

C. Decline in the singular and plural: mein sehrer, ihre Tod)ter, jein Yöffel, biejes (Ssemüldo, das Fenjter, ber Sellner, ber Engländer, weld)ez Mleijer.

\section{WRITTEN EXERCISE}

1. Miss Brown has two brothers; they are both teachers in our school. 2. Her father and grandfather were painters; they painted many pictures in our town. 3. Those big birds are eagles; there are many eagles here in the high mountains. 4. These children are the grandsons of our gardener; they have a little brother, but he is not here to-day. 5. The little children sang; it sounded very pretty. 6 . We found many apples, but they were not ripe. 7 . Are the windows of your room open? 8. The birds are singing; how beautiful it sounds! 9. There is a bird in that little tree; he is singing beautifully. 10. There are birds enough in the gardens, but they do not all sing. 11. The waiters here are all Englishmen. 12. There are no knives and spoons here, waiter! 13. They are Americans, but they speak German. 14. The uncle of these girls has rented a cottage in the mountains. 15. Did you sleep well (gut)? Yes, thank [you], I slept very well. 


\section{LESSON XXVII}

79. Second Class of Strong Nouns. - The plural is formed by adding $\mathfrak{c}$. Monosyllabic masculines in this class generally modify the stem-vowel, feminines always, and neuters very rarely.

(1) To this class belong:

I. Most masculines not in Class I, as:

Der Bleiftift, bie Bleiftifte. Der Etŏaf, die Störfe.

II. Some feminines, mostly monosyllabic, as:

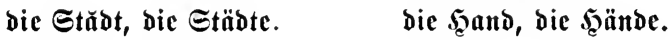

III. Many neuters, as:

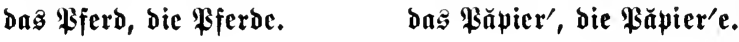

SingulAR

the son. the day. the hand. the horse.

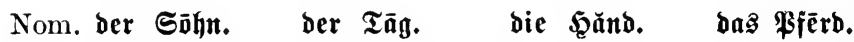

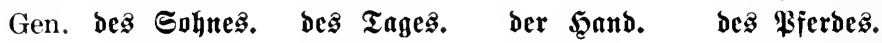

Dat. bem Sohne. bem $\mathfrak{T} a g e$ ber $\mathfrak{g a n d}$. bem $\mathfrak{B f e r b e}$.

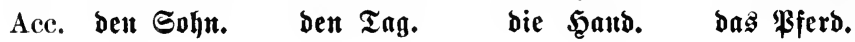

\section{Plural}

the sons. the days. the hands. the horses.

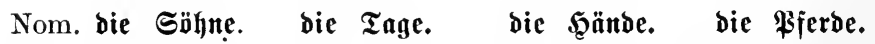

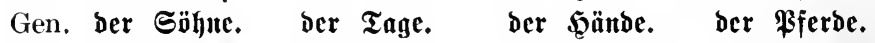

Dat. Den Gähnen. ben $\mathfrak{T}$ agen. ben

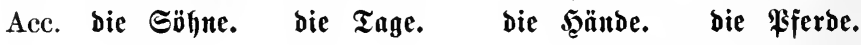

Note. - The rules for this class are less definite than the rules for the other classes of noun declension; but, in a general way, it may be said that it is principally a class of monosyllabic masculines. 
80. The Genitive of Time. - Indefinite time is expressed in German by the genitive:

Des $\mathfrak{T} \mathfrak{a g e} \mathfrak{z}$ arbeitet er, he works by day.

(Cines $\mathfrak{i}$ 'butbs war id) ba, I was there one evening.

81. The Accusative of Time. - Definite time and duration of time are expressed by the accusative:

$\mathfrak{D e n} \mathfrak{n}^{\prime} \mathfrak{T a g}$ arbeitete $\mathfrak{e r}$, that day he was working.

Diejen Sommer war id) ba, this summer I was there.

Эd) war ba cinten $\mathfrak{i} \mathfrak{a g}$, I was there one (whole) day.

\section{VOCABULARY .}

ber $\mathfrak{F} \bar{u} \tilde{z}, "$ "e, the foot. ber $\mathfrak{Q} \vec{u} t, " e$, the hat.

ber $\mathfrak{S a n d i d j u h},-\mathfrak{c}$, the glove.

ber Stall, ${ }^{\mathrm{e}}$, the stable.

ber $\mathfrak{A} u f f a k_{\text {, }}$ " ${ }_{\mathrm{e}}$, the composition, essay.

ber $\mathfrak{R a d}$ mittag, $-\mathfrak{e}$, the afternoon. ber Miorgen, -, the morning.

bie $\Re a d t, "{ }_{e}$, the night.

bic $\Theta_{d j} \bar{n} l^{\prime} \mathfrak{a r b c i t}$, -ent, the schoolwork.

bag Sdjwein, -e, the piry. gehen, ging, ijt gegangen, to go, walk.

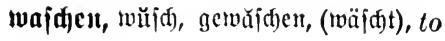
wash.

miide, tired.

rein, clean.

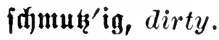

ipǟt, late.

heute morgen, this morning.

nadyts, at night.

ct'wăs, some, somewhat.

กūu, now.

\section{READING EXERCISE}

1. Der Bater ijt gejtern in Der Etadt gewejen uno hat

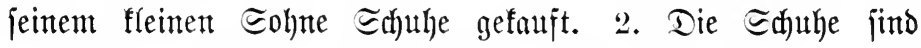
ihm aber ju flein, denn feine Jitīe juto jehr groß̧. 3. Der Eolnn ijt jehr gewadhjen, feine giöffe fint ihm alle ju flein.

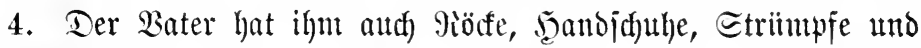
einen Şut gefauft. 5. Eie waren lange nidyt in ber Etabt, benn fie wohnen auf dem sande. 6. Des Miorgens ijt ber 
Sohn in ber @dule, des Miadjmittags hiitet er bie Riihe. 7. Cein

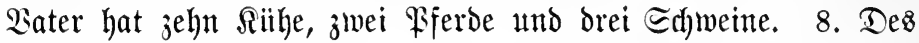

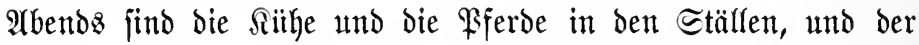
Solnn mad)t jeine Sduularbeit. 9. 2iadhts julälft er gut, benn er ijt recht milide. 10. Zwei Sithe feines 2aters jint biejen Sommer gejtorben, er hatte jie aber immer gut gehütet. 11. Er ijt zehn Gahre alt. 12. Yiun ijt er nadh Şauje getommen und

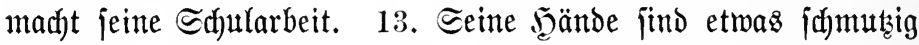

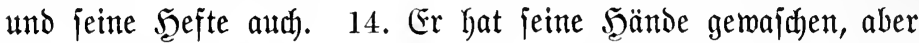
jie jind nidht ganj rein geworden. 15. Er fareibt einen $\mathfrak{2} u \mathfrak{f}=$

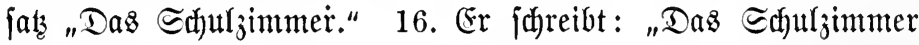
hat vier $\mathfrak{B a ̈ n d e}$ und brei Fenjter. 17. Sn bem $\subseteq$ fuljimmer jinto Bänfe, $\mathfrak{B u l t e , ~ B l e i j t i f t e , ~ S e e j t e , ~ j e h n ~ @ d j u ̈ l e r ~ u n d ~ e i n ~}$ Rehrer. 18. $3 \mathfrak{n}$ Dem $\mathfrak{3 u l t e}$ des Sehrers jind zmei Stöde. 19. Des Morgenz bin idy in ber Sdule und lerne. 20. Şeute morgen bin idh fpät zur (to) Schule gefommen, benn id habe zu lange geidhlafen. 21. (bejtern abend bin id zu fpät zu Bett gegangen. 22. Jetzt gehe idh jut Bett, benn id bin jehr mïbe."

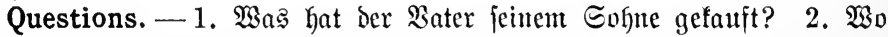
hat er bie Sachen (things) gefauft? 3. Wo wognen jie? 4. Samn ijt der Eofn in ber Edfule? 5. Wann hü̈tet er bie תïhe? 6. Wie viele

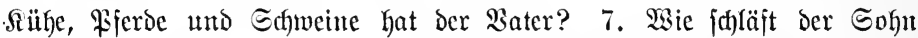

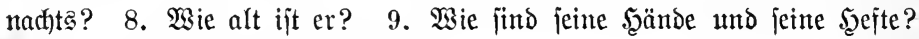

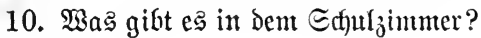

\section{DRILL}

A. Give the singular of all the nouns in the Reading Exercise.

B. Decline in the singular and plural: Der SHut; bie Madft;

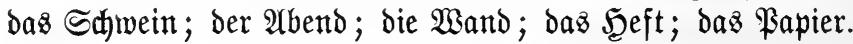




\section{WRITTEN EXERCISE}

1. My mother has bought me shoes, stockings, gloves and a coat. 2. I have grown, and my coat is too small for me. 3. I have not been in (the) town for a long time. 4. In the morning I am always at school, in the afternoon I play, and in the evening I do my school-work. 5. Do you sleep well at night? Yes, for I am always very tired. 6. My father had four horses, but now he has only two, for two died this summer. 7 . We have four cows in the stable. 8 . Where is IVilliam, has he come home? He has come home, (has) washed his hands, and is writing his composition. 9. My hands have become very dirty. 10. Where have you been? I have been in the stable. 11. This morning my hands were quite clean; I wash them every morning. 12. The benches and desks in our school-room are old, but always clean. 13. Your copybooks are not clean, Charles; you do not wash your hands enough. 14. William has grown very [much] this year. 15. He has done his school-work and has gone to bed. 16. He had come home and had gone to bed.

\section{LESSON XXVIII}

82. Third Class of Strong Nouns. - The plural adds -er, and the root vowel (when $\mathfrak{a}, \mathfrak{o}, \mathfrak{u}$ ) takes the umlaut $\left({ }^{"} \mathfrak{c r}\right.$ ).

(1) To this class belong:

I. Monosyllabic neuters, as:

baz Sint, dic Rittder.

bå Bud, bie Büđer.

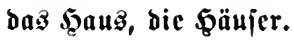
bัミ Lamm, die Lämmer.

II. Nouns ending in tum, as:

Der Mieid'tum, bie Micid'tiimer, the riches. Der $\mathfrak{J r} r^{\prime}$ tum, die $\mathfrak{I r r}$ 'tümer, the errors. 
a. Other nouns ending in -tum are neuter, as: bas ̊önigtum, the kingship.

III. A few masculines, mostly monosyllables, of which the commonest are:

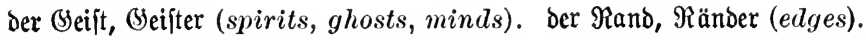
der (Sŏtt, (S) ötter ( gods). ber $\mathfrak{B a ̆ l d , ~} \mathfrak{B a ̈ l d b e r ~ ( f o r e s t s ) . ~}$ der Reib, Reiber (bodies). Der $\mathfrak{B u r m}, \mathfrak{W u ̈ r m e r ~ ( w o r m s ) . ~}$ der Mann, Männer (men).

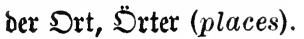
der Bormund, Bormünder (guardians).

Nотв. - As the gender of German nouns is a difficult matter for the beginner, one practical rule is this: A noun that forms its plural by adding -er is neuter, excepting as mentioned above (II and III). There are no feminine nouns declined in this way.

Nom. Då̉ Rinb.

Gen. bez Rindes.

Dat. Dem Rinbe. Acc. bå Rinb.

Nom. Die Rinber. Gen. Der $\Re$ intor. Dat. Den Riutberu. Acc. bie Rittber.

Singular

ber Irrtunt.

bes $\mathfrak{I r t u m}$.

bem Srrtum.

ben $\mathfrak{T r} r$ tum.

Plural

Dic Jrrtümer. ber $\mathfrak{I r r t i ̈ m e r .}$ Den Irrtümern. die Irrtïmer. ber Miaun. bes Mlaunes. bent Manue. ben Miann.

\section{VOCABULARY}

bå $\mathfrak{T} \overline{\mathfrak{a} l}$, " bas $\mathbf{Q} \check{\mathfrak{d}}$ ), " bå $\mathfrak{Q} \mathfrak{a m m}, \Perp_{\mathfrak{e r}}$, the lamb. bas $\mathfrak{g a u p t , ~ " e r , ~ t h e ~ h e a d . ~}$ enthaup'ten, to behead.

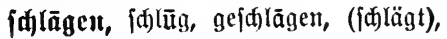
to strike, beat.

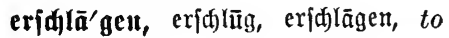
slay. grāben, grū̄b, gegrāben, (gräbt), to dig. begr $\overline{\mathfrak{a}}^{\prime} \mathfrak{b e n}$, begrūb, begrāben, to bury. halten, hielt, gehalten, (hält), to hold. erfalten, erfielt, erfalten, to receive. bchalten, behielt, behalten, to keep. geitehen, gejtano, gejtanden, to confess. zertre'ten, zertrat, zertreten, (zertritt), to trample on. zählen, to count. veripie'len, to gamble away. 


\section{READING EXERCISE}

1. Wir haben biejen @ommer in einem fleinen Srte in bem Walde gemohnt. 2. Sn einem Tale biejes $\mathfrak{W a l}$ ses jtand ein

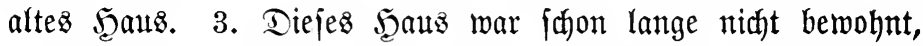
ez war ganz zerfalfen, und nahts fpielten die (Seijter barin. 4. Ein Sohn hatte feinen alten $\mathfrak{B a t e r}$ in Dem Şauje erjaflagen, hatte bann ein Rod) in bem (5arten gegraben und den Reib barin begraben. 5. Diejez erjählten unz bie Rinber dez Dorjez. 6. Eines Iages hatte Der Sohn jein Geld veripielt, der Bater hatte den (that) Tag (jeld erhalten. 7. Ez war nadts, ber Bater zählte jein Steld, Der Cohn trat in bas Bimmer, er hielt

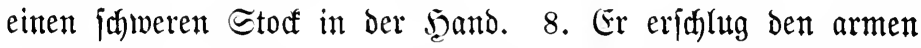
alten Bater. 9. Dann hat ber Sohn baz Şaus verfauft und ijt nach $\mathfrak{A}$ merifa gegangett. 10. Sa ij er reich gemorden. 11. Alber er hat feinen Meidhtum nidht behalten, fpäter fam er ganz arm nach bem Torfe zuriicf. 12. Er gejtand allez. 13. Die Männer des Dorfes gruben in dem (Garten, aber jie fanden nidfts. 14. Mian hat ben Sohn enthauptet. 15. Fs gibt zmei (Seijter da, ein (Beijt hat fein Şaupt. 16. Drei Männer in Dem Dorfe haben jie gejehen uno bejarieben, aud hatten bie Beifter ben Garten jertreten. 17. Diejes war aber ein Grrtum, denn zmei ?ämmer waren barin gewejen. 18. Wir haben bas Sauz, aber feine (beijter gejehen.

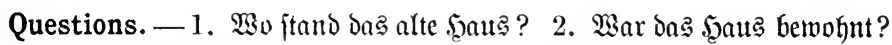
3. Wie war bas 5̧auts? 4. Wer fpielte nadfte barin? 5. Wen hatte der Eohn erfidlagen? 6. Mo hatte er Den Leib begraben? 7. Wobjin (whither) ift ber Sofn fpüter gegangen? 8. Wie fam er nad) Dem Dorfe zurüd? 9. Franden die Miänner des Dorfę etwas in Dem Barten? 10. Wer hat Die Beifter gefehen? 11. Wie war Der Barten? 12. Wer war in Dem Barten getwejen? 13. Bibt es (beijter? 


\section{DRILL}

A. Give the plural of all nouns in the Reading Exercise.

B. Give the genitive singular and nominative plural of: Der Bater; die Mutter; Der Sohn; Der Mann; die Stadt; bas Dadh;

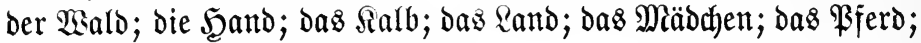
bas Dorf; ber $\mathfrak{B r i e f} ;$ bie Todhter.

\section{WRITTEN EXERCISE}

1. Did you live in the forest this summer? Yes, the house stood in the forest. 2. Please describe the house to me. 3 . It was very old and decayed. 4 . There were big holes in the roof. 5. I confess that house is very old. 6. The little villages in these valleys are very pretty. 7 . The houses stand in the forest. 8. The men had dug holes in the garden, but they had found nothing. 9. These houses are not inhabited, and the children play in the gardens and trample on the flowers: 10. There are worms in these apples. 11. Count the money, but do not tell how much you have. 12. They slew John Brown's body, but not his spirit. 13. Who told you that? The teacher told us that this morning. 14. Have you received the money? Yes, I have received the money and have kept it. 15. He has kept his riches; he has not gambled them away. 16. We have seen the old houses, but we have seen no ghosts. 17. His lambs have died, and he has become very poor. 18. Hold the stick, but do not beat the poor dog.

\section{LESSON XXIX}

\section{Weak Declension of Nouns.}

(1) Nouns of the weak declension (called also the $\mathfrak{n}$ declension) form their plurals by adding the ending $\mathfrak{n}$ or $\mathfrak{c}$. Feminines, of course, have no ending in the singular; masculines add $\mathfrak{n}$ or $\mathfrak{c}$ to form the genitive, dative, and accusative. 
(2) Here belong:

I. The great majority of feminine nouns, as:

dic Frau, pl., dic jrnuen. dic Єđwejter, pl., dic Eqwejtern.

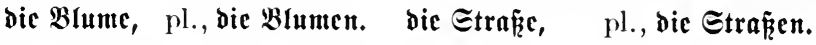

Note. - About one half of the feminine monosyllables belong here, and all feminine polysyllables except $\mathfrak{M} u t t e r$ and $\mathfrak{I}$ odfter (Class I) and those ending in $\mathfrak{n i}$ and jal (Class II).

II. Masculines ending in $\mathfrak{c}$, as:

der $\Re \mathfrak{n a b c}$ des $\Re \mathfrak{i n b e n ; ~ p l u r a l , ~ d i c ~} \Re$ naben.

III. A few masculines formerly ending in $\mathfrak{c}$, but now monosyllabic, of which the commonest are:

Der Fitrit, -cin, the prince (nobility). Dor Scorr, -en, the gentleman, Mr., ber $\mathfrak{F r i n}$, , $-\mathfrak{c}$, the prince (royalty). master, lord.

Der (B́rāf, -eil, the count.

Der Syels, -cil, the hero.

Der Soirt, -ent, the herdsman.

der Bär, -cu, the bear.

der Chriit, -ent, the Christian. ber Menid), -cn, man (human being), fellow.

Der E(t) $s,-e n$, the ox. $\left.\begin{array}{l}\text { Der } \text { Iōr, -ent, } \\ \text { Der Piarr, -chl, }\end{array}\right\}$ the fool.

IV. Most foreign masculines with final accent, as:

ber Etubent' (student), bie @tuben'ten. ocr $\mathfrak{P r} \overline{\tilde{a}^{\prime}}$ jibent' (president), bic $\mathfrak{B r a ̈}$ jiben'ten.

Singelar

the boy.

Nom. ber $\Omega$ inabe.

Gen. dos $\Omega$ naben.

Dat. dem Sinaben.

Acc. ben $\Omega$ naben.

Nom. dic Snaber.

Gen. ber $\Re$ naber.

Dat. den Sinaben.

Acc. dic $\Omega$ naben. the man.

Der Mienid).

bes Mieniden.

beit Mienidjen.

ben Mienja)n. the sister.

Dic Educiter.

ber Edjwejter.

ber Entwejter.

die Equejter.

\section{Plitral}

dic Mienjdjen. die Sdjwejtern.

Der Mienjacn. ber Edjwejtern.

ben Mienidjen. ben Edyuejtern.

bie Micnjaen. dic Snwejtern. 
(3) jerr takes only $\mathfrak{n}$ in the singular, but $\mathfrak{c} n$ in the plural: Des Soerm, of the gentleman, but bie Seerren, the gentlemen. Mieine Iamen uno Scerren! Ladies and gentlemen!

Note. - In addressing envelopes write: $5 \mathfrak{g e r m} \mathfrak{M} . \mathfrak{M e y e r}(t o \mathrm{Mr}$. W. Meyer).

(4) Masculine nouns in c denote males, hence follow natural gender, as: Der Sinabe, the boy. Other nouns ending in c are mostly feminines, as: bie Blume, the flower; bie Tinte, the ink.

NoтE. - There is no umlaut in the weak declension. No neuter nouns are found here. Masculine nouns belonging to the weak declension do not form the genitive in $\mathfrak{\mathfrak { s }}$, but in $-\mathfrak{n}$, or $-\mathfrak{e} \boldsymbol{n}$.

\section{Rules of Gender.}

(1) Nouns ending in $\mathfrak{c i}, \mathfrak{h} \mathfrak{c i t}, \mathfrak{f} c i t, \mathfrak{j} \mathfrak{d} \mathfrak{a f t}, \mathfrak{u m g}$, and in are feminine. They belong to the weak declension.

These endings form nouns from verbs, adjectives, and other nouns, as:

Der $\mathfrak{B a ̈ c f e r , ~ t h e ~ b a k e r . ~}$ frei, free.

fremo'lidf), friendly, kind. Der Fremt the friend. bemerfen, to remark.
Die Bäfferci', the bakery Die Frei' $\mathfrak{y}$ cit, the freedom, liberty. Die Freun'lid)feit, the friendliness. bie Fremt'fidaft, the friendship. bie Bemer'fung, the remark.

(2) The suffix -in forms feminines from masculine nouns, often with umlaut. Such nouns usually denote occupation or nationality; they double the $-\mathfrak{n}$ in the plural:

\section{- Masculine}

der Qefrer, the teacher. der Braf, the count. Der Imerifán'ner, the American.

\section{Feminine}

bie 2 ef'rerin, the teacher. bie (Srä'filt, the countess. die Sumertifā'nerin, the American.

Plural: die Sebrerimen, (Grä'finuen, Imtertifa'nerinuen.

(3) Nouns ending in c are, with few exceptions, feminine. 


\section{VOCABULARY}

Der $\mathfrak{R a}$ tăgerr, -cll, the councilman. ber $\mathfrak{S a j e},-n$, the hare. Die Dame, -n, the lady. bie Sounte, $-n$, the sun. die Strāeze, -nt, the street. Die Obabel, -n, the fork. die Univerjität', -en, the university .

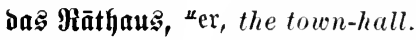

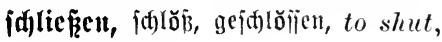
close, lock. fideinen, idjien, gejoienen, to shine, seem.

fah)ren, fulfr, ijt gejahren, (jührt), to drive, travel, ride.

empian'gen, empfing, empiangen, (empiängt), to receive.

verren'fen, to sprain.

faul, lazy, idle.

แăă, wet.

\section{READING EXERCISE}

1. Die Sdyejtern biejes fleinen Sunben jumb Edjillerinnen

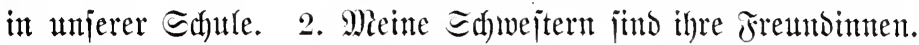
3. Wir haben in ber Edylule einen Pehrer und brei Sehrerinnen. 4. Die Şerren pflit(ften joböne Blumen und gaben jie ben jungen Damen. 5. Der Sohn Des sïrjten Bismtarf war auth ein sitrit. 6. $\mathfrak{I n}$ Ifmerifa gibt ez feine sitriten, aber 9 mmerifanerinnen werben oft Fitritimen. 7. Der Eohn unjeres Präjibenten ijt ein Stubent biejer llniberjitüt. 8. 3n biejen grojen Märlbern gibt ez Bären aber feine ந̧ajen. 9. Jah habe bie Titren ge= jdhlojien, jie waren offen. 10. Tie sirdhen jint alle gejdhlojien, benn heute ijt teine Sird)e. 11. Die Eome idheint, bie Blumen blïhen, ber Sommer ijt ba! 12. Es gibt Sdjen bier, aber feine Sïhe. 13. Die Birnen jund biejes Gahr nidht reif ge= worben, benn bie Eonne hat nidgt geichientent. 14. Die Etrajen waren boll Mienjhen, Denn ber Saijer unt bie Saijerin juthren nad) bem neuten 9iathanje. 15. Tie giatsherren haben jie in Dem Mathauje empjangen. 16. Siso jimo bic (5abeln? idh jehe Mejier unt söfiel, aber teine Gabeht. 1r. Die Pehrerin hat dem $\Omega$ naben $\Xi$ hulaufigaben gegeben, aber er hat jie nidyt gemad)t, 
er jaheint faul ju jein. 18. WBir jind nad) Berlin gejahren und baben den Saijer gejelen, aber bie Siaijerin war nidgt ba, Denn jie war gefallen und hatte Den Jü berrenft. 19. Eine Freunbin meiner Miutter Gatte bie Freund(idffeit mid) nad) Berlin mitjunehmen. 20. Ghre Freunojajajt ju meiner Miutter ijt jebr gro $\tilde{\beta}$.

\section{DRILL}

A. Form the feminines to: Eqhueiber, Serr, Edfitler, Student, Präjionent, Saijer, siönig, Chrijt.

B. Give the plural of the following nouns: ber Pelyrer, bie Srbwejter, der Bruder, das Miefier, bie Gaber, der Eöffel, der

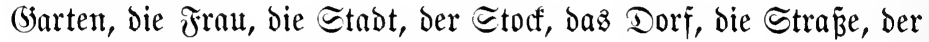

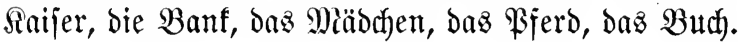

C. Decline in the singular and plural: Der Seerr, bie Dame, die Schilferin, ber Etubent.

\section{WRITTEN EXERCISE}

1. Give the boy the book; he will give it to his teacher, for it is her book. 2. His sisters are the friends of my sister. 3. The girls are students in (of) our university. 4. How many churches are there in this town? There are three churches, but they are closed to-day. 5. Shut the doors; it is cold. 6. The wife of the President drove to the town-hall. 7. The councilmen will receive the President in the new town-hall. 8. The sun has not been shining, and the streets are wet. 9. Give the pretty flowers to the young ladies and gentlemen. 10. Bismark was a count, but he became a prince. 11. I have often seen the prince. 12. The oxen drew the cart, and thus we drove to the town. 13. My friend was not there to receive us; she had fallen and had sprained her foot. 14. I saw a hare in the woods to-day; it seemed to be very big. 15. This boy seems to be a fool, but he is only lazy. 
16. Waiter, I have a knife and a spoon, but no fork! There are the forks! 17. Men and women, boys and girls were walking or driving in the garden of the prince. 18. The empress is a friend of his wife. 19. Their friendship is very old. 20. She is the wife of a count, and so she is a countess.

\section{LESSON XXX}

\section{Prepositions.}

(1) In German some prepositions govern the genitive, some the dative, some the accusative, and some both dative and accusative. Hence, in learning the prepositions, the case they govern should also be earefully learned.

(2) Prepositions take their meaning from the phrases in which they stand; hence some have many meanings. Compare in English: 'he stood $b y$ the house'; 'the house was built by him'.

Note. - As the use of a preposition in German differs often from its English equivalent, especially with verbs, the whole phrase should be carefully noted, as: er bat um bas Beld, 'he asked for the money'. The English equivalent for um is 'around'; the German für is the common equivalent of 'for'. Where the use of a preposition with a verb varies from the English, it is given with the verb in the vocabularies, as: ask for, bitten um (acc.).

\section{Prepositions governing the Accusative.}

bŭrd), through.

fiir, for.

ōhne, without.

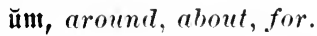

fönber, without (seldom used).

$\mathfrak{g}^{\mathbf{e}} \mathbf{g} \mathfrak{g} \mathfrak{n}$, against, towards.

wiber, against (seldom used).

The following doggerel may be used for memorizing:

Durth, fiir, offuc, um,

fouber, gegen, wiber.

Exhreibe jtets stftujativ,

Ilno nie ben Datio nicoer. 
87. Infinitive with $\mathfrak{l} \mathfrak{M} \ldots \mathfrak{z}^{\mathfrak{l}}$. $-\mathfrak{l l m}$, followed by $\mathfrak{j} \mathfrak{l}$ with the infinitive, expresses purpose; corresponding to the English 'in order to':

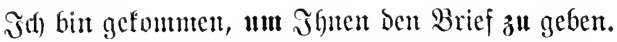

I have come (in order) to give you the letter.

88. Irregularities of Noun Declension.

(1) Nouns which are declined strong in the singular, but weak in the plural, form the so-called Mixed Declension. To the mixed declension belong a few masculine and neuter nouns, of which some of the most common are:

Nom. Singular

ber Bauer, the peasant.

ber Ger, the lake.

ber Miajt, the mast.

Der Stant, the state.

ber $\Re \breve{a} \mathfrak{a}$ 'bār, the neighbor.

ber Sdjmerz, the pain.

ber Better, the (male) cousin.

$\mathfrak{d a \mathfrak { s }} \mathfrak{A} \mathfrak{u g} \mathfrak{e}$, the eye.

Das $\mathfrak{D h r}$, the ear.

Dag Batt, the bed.

bas Eube, the end.
Gev. Singular

bes Bauers.

De: ভcc .

Des Miajte?.

bc: Stantes.

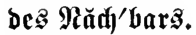

Dez Sthmerzes.

bes Betters.

Deß $\mathfrak{A}$ uge

De Dhres.

Des Bettea.

bes Endes.
Nom. Ploral

die $\mathfrak{B a u e r n}$.

Die Eeen.

bie Miajten.

bie Stanten.

bie $\mathfrak{M a ̆ a ̆ d} \mathfrak{b a r n}$.

bie Sđmerzen.

bie $\mathfrak{B e t t e r n .}$

bie $\mathfrak{A} u \mathfrak{g e n}$.

Dic Dhren.

bie Betten.

bie Enton.

(2) Some masculines, formerly ending in clt, have dropped the $\mathfrak{n}$ in the nominative, but have kept it in the other cases, and are declined like nouns in $\mathfrak{c n}$ of the first class of the strong declension. Such are:

Nom. Singular

ber liame, the name.

ber Fricoc, the peace.

bcr $(B \mathfrak{c o n n}$ 'fe, the thought.

ber $\mathfrak{B} \mathbf{u} \mathfrak{d})^{\prime} \mathfrak{i} \mathbf{t a ̄ b c}$, the letter.
Gen. Singular

bez Miāmen.

bez Frieden?.

dez (bedan'fenz.

De: $\mathfrak{B u d \mathfrak { d }}$ 'jtaben?.
Nom. Pldral

die Māmten.

dic Frieben.

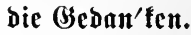

bie $\mathfrak{B u d} \mathfrak{d}^{\prime}$ jtaben.

Dat. and Acc. Sing.: Mamen, Frieben, Bsebanten, Budfjitaben. 


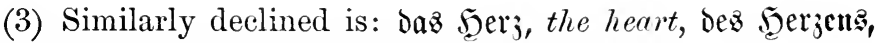

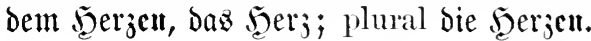

Note. - The division of German nouns into declensions serves as a guide for the beginner in determining the genitive singular and the plural; but in general the pupil should rely on observation and memory; as he should also in determining the gender of nouns, where no sex is implied.

\section{VOCABULARY}

ber $\mathfrak{B}$ ind, -e, the wind. bie Ere, -nt, the sea. bie Miark, the mark (German coin $=24$ cts.). bas ভndifi, -e, the ship.

bas $\Xi \mathfrak{d} \mathfrak{l a} \mathfrak{f}^{\prime}$;inmmer, 一, the bedroom. bitten, bāt, gebēten (um), to beg, ask (for).

\section{READING EXERCISE}

1. Sit biejes neue Buth für mid ober für Eie? Es ijt fïr Sie. 2. Die fleinen Sinaben liejen butch) Den (Jarten $\mathfrak{n}$ th $\mathfrak{m}$

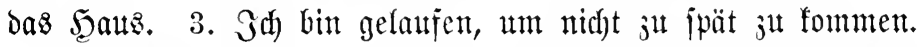
4. Daz Sind ijt ohne jeinen Sater und jeine Mutter gefommen und ijt gegen Den Baum gelaujen. 5. Er bat midh um (5eld, und id habe ihm brei Marf gegeben. 6. Wir haben Sitgen,

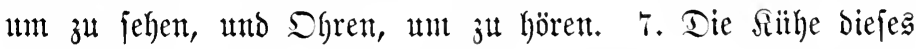
Bauers jind burd) unjeren (barten gelaufen und haben alle Blumen zertreten. 8. Эa) hörte ben Mamen bez Bauters nidht. 9. Die Majten biejer Edjifje jimb jehr hoch. 10. Ter 巨ee ijt heute jegr rufig, es gibt feinen sind. 11. Die Eee ijt nidjt oft ruthig, ba gibt es mehr sinto. 12. Nieine âtgent find nidft gut genttg, um bieje Butdjtaben ju Kejen. 13. Die Etaaten haben Frieben, alles ijt ruhig. 14. Die Gedanten ber Mienjanen jind nicht immer bie Bebanfen des Jriedens. 15. Ter Mann war gefalfen und hatte Edhmergen. 16. Ter gute Chrijt hat Frieben in Seerjen. 17. 3n bent grop̈en Zimmer waren Betten fïr bie Inaben, ez war ihr Edflajimmer. 18. Taz 
Feniter war offen, und Durch das Feniter fam ber falte Wind. 19. Eeine Yad)barn waren Bauern. 20. Dieje Inaben find Bettern, ihre Bäter jinto Brilder.

\section{REVIEW DRILL}

A. State the various ways in which the plural of German nouns is formed, giving turo examples for each class.

B. Give with definite article the singulur of the following

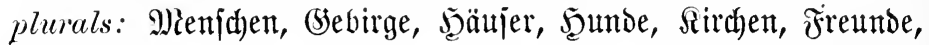

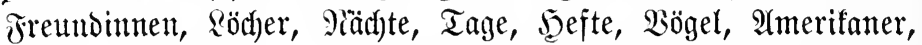

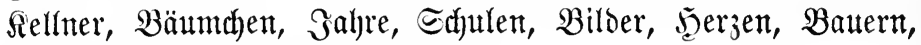
Majten, Edjiffe, Winde, ভtubenten.

C. Give the genitive singular and the nominative plural of: ber Serr, bieje Dame, mein Eofn, jein Sind, fein Miäbdhen, Der

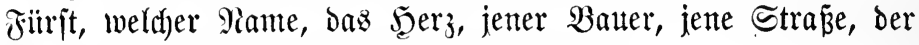
Saijer, die Saijerin, unjer $\mathfrak{B a t e r , ~ i h r e ~ M u t t e r . ~}$

\section{WRITTEN EXERCISE}

1. This pencil is for you, and not for her. 2. The little children are running around the lake. 3. They ran against a man, and he said: "Have you no eyes, children?" 4. They went without their father. 5 . In these states the great lakes are very pretty. 6 . He has come to see you, not me. 7. She asked her for the money. 8 . He is rumning, in order not to come too late. 9. These farmers are very rich; they have horses, cows, oxen, and lambs. 10. The ears of this horse are very small, but he hears very well. 11 . I see the masts of the ship; she has wind enough, and the sea is quiet. 12. I did not hear the names of these children, but they are the children of a poor peasant. 13. This small child reads his letters very well. 14. Where have you pain? In my heart. 15. The dog ran through the room. 16. The men went through the garden 
towards the house. 17. The boys are not at home, and there is peace in the house. 18. The thoughts of these men are not always good. 19. The beds are in the bedroom. 20. This is the end of the exercise.

\section{LESSON XXXI}

89. Prepositions governing the Genitive. - The more common are:

jtatt, aujtatt, instead of.

trotz, in spite of. während, during.

$\mathfrak{w} \overline{\mathfrak{e}} g \mathfrak{e n}$, on account of.

Note. - wegeu often stands after its object, as: Des Baters wegen, on account of the father; but also, twegen Des 9 aters.

90. Prepositions governing the Dative.

$$
\begin{aligned}
& \mathfrak{a} \mathfrak{H} \text {, out of, from, of. } \quad \mathfrak{n} \bar{a} \mathfrak{t}) \text {, after, to, according to. } \\
& \mathfrak{a} \mathfrak{i} \mathfrak{e r} \text {, except, besides. } \quad \text { jeit, since. } \\
& \text { bci, by, at, with. vŏn, from, of, by (agent). } \\
& \text { mĭt, with, along with. } \quad j^{\overline{\mathfrak{u}}} \text {, to, at. }
\end{aligned}
$$

(1) and), in the sense of 'accorling to', generally follows its object:

biejem Brieje nad), according to this letter.

But, nad brei llhr, after three o'clock.

(2) English 'to' expressing motion is, with persons, $\mathfrak{z}^{\mathfrak{t}}$; with places, mady, unless it is rather the occupation than the place that is implied; in which case $\mathfrak{z}^{\mathfrak{l}}$ is used:

Er ging z" jeinem Bater, he went to his father. Er ging uad Berlin, he went to Berlin. Er gert und Der Edulue, he goes to the school (building).

But, Er geht jur (引u ber) Ełhule, he goes to school. 
(3) English ' lyy' is wou, when it denotes the agent, as:

Der Brief war von ibm geid)rieben, the letter was written by him.

When it denotes position it is $\mathfrak{b} \mathbf{i}$, as:

Der Baum jtegt bei Dem Sauje, the tree stands by the house.

a. bei has also the meaning 'at the house of'.

Id) war bei ifm, I was at his house.

(Er wohnt bei feinem Dufel, he lives at his uncle's.

b. bei, with a pronoun, also expresses 'about me', or 'with me'.

If habe fein (beld bei mir, I have no money about me.

c. It also expresses 'during', 'while'.

Beim Efijen murbe er trant, while eating he became ill.

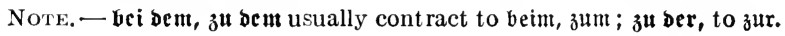

91. Nouns of Weight and Measure; Partitive Genitive. Nouns of measure, weight, or value (except feminines in $-\mathfrak{e}$ ) are always used in the singular (cf. English, 'two inch plank'):

3wei 3oll biff, two inches thick.

vier $\mathfrak{B}$ futd $\mathfrak{B u t t e r}$, four pounds of butter.

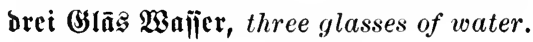

But, zwei Tafien $\mathfrak{T e e}$, two cups of tea.

(1) Notice, in the last three examples, that the qualitative noun following stands without case, inflection, or preposition, thus also:

Giut Stït $\mathfrak{B} r \bar{n} t$, a piece of bread.

(2) Mann may also be used in the singular in a collective sense:

Drei Mann finto nidft genug für die $\mathfrak{A} r$ reit.

Three men are not enough for the work. 
(3) If, however, there is an adjective with the qualitative noun, the genitive may be used, as:

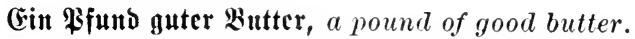

But also: Gin $\mathfrak{P}$ futt gute $B$ utter (gute Butter is in apposition with cin Piund).

\section{VOCABULARY}

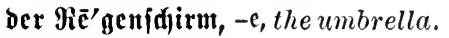
ber Cent, the cent.

Dar Dol'lar, the dollar.

ber Tce, the tea.

bie $\mathfrak{T} \mathfrak{n} i \mathfrak{i},-n$, the cup.

bie $\mathfrak{P o j t} \mathfrak{y}^{\prime} \mathfrak{f a r t c},-n$, the postal-card.
Das Glàs, " "r, the glass. hölen, to fetch, get, bring. nie'măno, nobody. breit, broad. wicber, again.

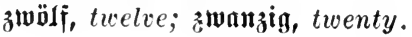

\section{READING EXERCISE}

1. Statt eines langen Briefes betam iđ mur eine Pojtfarte non ihm. 2. Troz bes jtarfen Regens ging er ohne jeinen

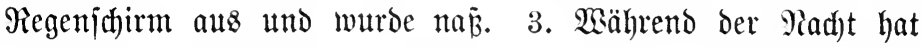
es immer geregnet, aber währento des Tages war bas wetter

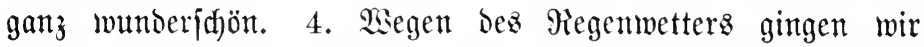
nidht aus bem Şauje hinaus; nad) bem Tegen wurbe bas wet= ter aber jebr jujön. 5. Er hat es nur dez (belbez wegen ge=

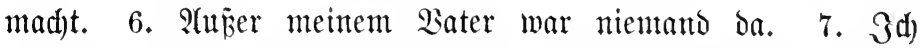

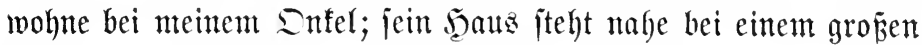
Walbe. 8. Gd) fpiele oft mit feinen Rinbern. 9. Er ging nad) bem Sanje jeines Freundez, aber niemand war ju Seauje, und jo ging er wieber nad) Saule. 10. Seit brei Tagen ijt er nid)t aus bem Bimmer hinanzgefonmen. 11. Sd habe gejtern einen langen Brief von ihm befommen. 12. Der Brief war von ihm geidrieben, nidft von ifr. 13. Er ging nad) Berlin $j_{\mathfrak{u}}$ jeinem Sater. 14. Ter fleine Sinabe geht jesen Tag jur Sdule. 15. (Er ijt nad) ber Sd)ule gegantgen, um feine Bitder 
3u holen. 16. Diejem Brieje nadh ijt er fajon jeit vier Tagen bei jeinem Freunde. 17. Rellner, geben Sie uns brei Błaz Wajfer und zmei Tajien Tee! 18. Diejez Zimmer ijt żmanjig

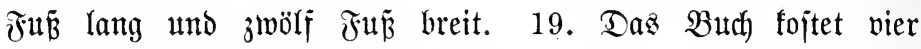
Marf, und id habe nur brei Mart bei mir. 20. Fünf Dollar find zmanjig Marf. 21. (beben Sie mir, bitte, ein Stïff $\mathfrak{B a}=$ pier und einen Bleiftift. 22. Sisir waren zwanjig Mann in dem Sdjiffe, aber ber $\mathfrak{B}$ into war ju jtart.

\section{DRILL}

Supply the endings:-

1. Statt $\mathfrak{d}$ - 2 sajfers hat ber Reltner mir Tee gegehen. 2. Trotz b- Wetters ijt er gefommen. 3. Jd) bin mit meinMutter aber ohne mein- Sater gefommen. 4. 2(ǚer $3 h r-$ Sdymejter fenne idh niemand. 5. Er fam aus jein- Zimmer. 6. Der Bater jtand bei jein- Bette. 7. Эd) geke nadh biejStabt. 8. Eeit biej- Tage habe idh ihn nidyt gejehen. 9. Die

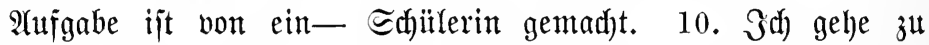
mein- હdyeiter. 11. Der Brief ijt fiir mein- Bruber.

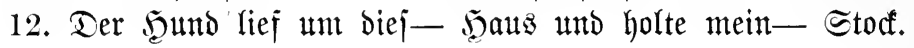

\section{WRITTEN EXERCISE}

1. I asked for a glass of water, but instead of the water she gave me a cup of tea. 2. In spite of the noise I slept very well during the night. 3. On account of the little children she did not go to Berlin with her husband. 4. She went to her mother and asked her for five cents. 5. The boy had forgotten his books, and he went to the school to get them. 6. He came out of the house, but forgot to close the door. 7. Besides the two girls nobody was at home, for the father had gone with the mother to the town. 8. By the tree stood a little house, and in it a tailor lived. 9. I was at his house, 
but he was not at home. 10. Since that day I have not been there. 11. I have not a (no) cent about me. 12. The exercise was written by me and not by my brother. 13. According to her letter she will come home to-morrow. 14. I have also a postal-card from her. 15. These beds are only five feet long; they are too small. 16. How much do they cost? They cost five dollars. 17. How much is a dollar? A dollar is four marks.

\section{LESSON XXXII}

92. Prepositions governing Dative or Accusative. - The following prepositions govern the accusative, when motion towarl the object of the preposition is expressed; otherwise, they govern the dative:

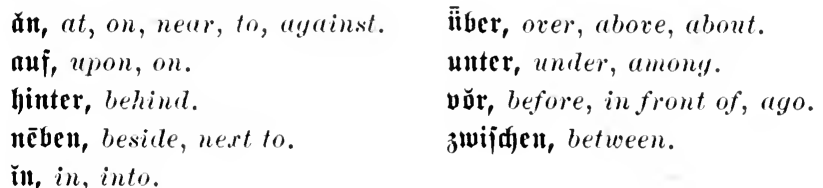

(1) The English 'where' is expressed by wo and woffin'. Wohin corresponds to the old English ' interrogatively, whenever it is a question of motion towards an object:

\section{Wohin gehen Eic? Where (whither) are you going?

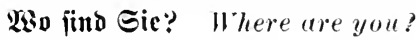

Hence the above prepositions govern the dative, when one can ask wo? lut the arcusative when one (an ask wobjin?

SGo jimb wir? SBir jint in bem Edfut jimmer.

פsofin geten wir? Sisir gefen in bas E(t)ulzimmer.

riso liegt bus buth? ?uf bem Tijq).

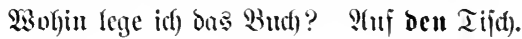


(2) The following rhyme, expressing the above idea, may be used for memorizing:

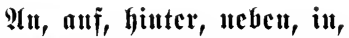 ïber, unter, vor und zwijucu,
Etefen mit bem Iffujatio
Wenn man fragen famu: $\mathfrak{S o h m}$ ?
Mit Dem Dativ jtehen jie jo,

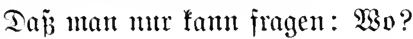

(3) These prepositions govern the dative when the verb expresses motion (or rest) within a place; the accusative, only when motion is toward the place, thus:

$\mathfrak{W}_{\mathrm{o}}$ geht er? Er geht in bem Garten, he is walking in the garden.

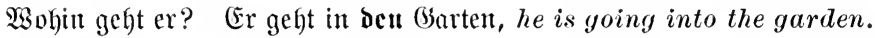

(4) When these prepositions are used in a figurative sense, (when one cannot ask wo or wohin) the tendency is to use the accusative, thus:

Wir ipredhen über Sie, we are talking about you.

Sie Dentt an midn, she is thinking of me.

Jid) j(t)reibe an fie, I am writing to her.

93. Use of $\mathfrak{P} \mathfrak{u}$ and $\mathfrak{A} \mathfrak{i}$. - $-\mathfrak{A} \mathfrak{n}$ generally contains the idea of 'against', and auf the idea of 'upon', a distinction which the English 'on' does not make:

Er faĩ an Dem Tijhe, he was sitting at the table.

Er $\mathfrak{j} \tilde{\mathfrak{a}} \mathfrak{a} \mathfrak{a} \tilde{f}$ Dem Iijhe, he was sitting upon the table.

Das Bilb hängt an Der $\mathfrak{B a n t}$, the picture hangs on the wall. Das Bilb lag anf Dem Iijtije, the picture lay upon the table.

Er jtellte Den Etufhl an Die $\mathfrak{X a n d}$, he put the chair against the wall.

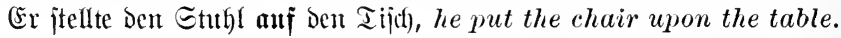

94. Contraction of Preposition and Article. - Some prepositions are frequently contracted with the definite article: 


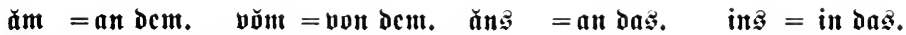

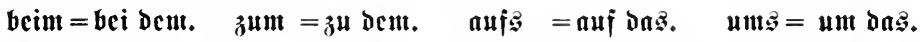

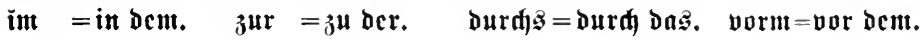

\section{VOCABULARY}

ber $\mathfrak{T} i \mathfrak{d},-\mathfrak{c}$, the table. ber Stuhl, " ${ }_{\mathfrak{c}}$, the chair. Der Sđanat, "e, the cupboard. Der $\mathfrak{B l a ̆ t z , ~ " e , ~ t h e ~ p l a c e , ~ r o o m . ~}$

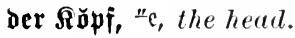
Die Sădjc, -n, the thing, affair. bas Sdjulbud, " "er, the school-book.

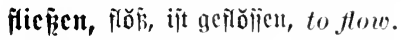
gię̧en, gòji, gegófien, to pour.

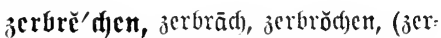
brict)t), to break to pieces.

legen, to lay, place.

fitllen, to put, place.

rollen, to roll.

iterfen, to stick, put.

heulen, to howl.

blutch, to bleed.

frazen, to scratch.

\section{READING EXERCISE}

1. Maries Sakze lag auf bem Bette uno jaflief. 2. Sarlz Seund fam in bas Bimmer mo bellte. 3. Tieben dem Bette

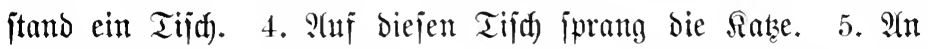
bem Tijht jtand ein Etuhl. 6. S(uf Den Etuhl iprang ber

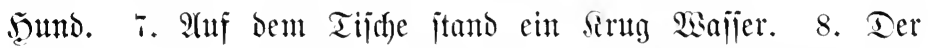
Seund jprung bann auj ben Tijh). 9. Ter sing fiel uno rollte bann vom Tifaje auf ben Tuphboben uno jerbrach. 10. Tas Majijer flö nom Tijhe auj Das Bett. 11. Die Sałze aber mar jafon unter bas Bett gejpruntgen. 12. Ter seumb frrang vom Tifde und licj unter bas Bett. 13. Stn ber sina jtand ein Edrant. 14. a(ber ber Edyrant jtanto nidyt ganj an ber

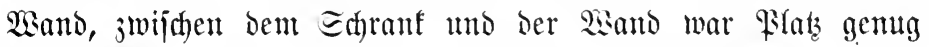

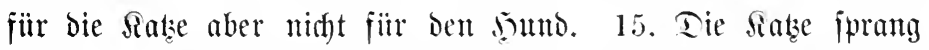
hinter ben Edhrant. 16. Ter bumb itano neben Dem Edranfe und bellte. 17. Tam jteatte er ben siopf hinter ben Edyrant. 18. Die Ratze trakzte ihm in bie ?tugen und lief bam aus bem 
Zimmer. 19. Der 5̧und blieb in dem Zimmer und heulte.

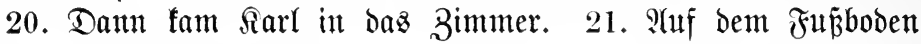
lag ber Sirug jerbrodfen, auj Dem Tijhe lagen jeine Shul=

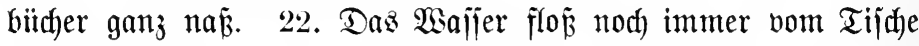
$\mathfrak{a} \mathfrak{i f}$ bas Bett. 23. Sein Şund blutete am Sopje. 24. Er

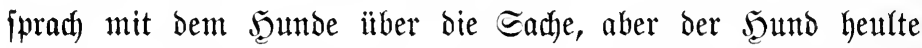
nur. 25. Seine Sabejter Marie war auj̃ Sand (country) gefahren, um einen Dnfel auf (for) zehn Tage zu bejudent. 26. Rarl jarieb iiber bieje (sejdidste an jie: "Deine Siaze hat ben Irug in meinem Zimmer jerbrod)en, hat bas $\mathfrak{x a j j e r ~ a u f ~}$ bas Bett gegofien und hat meinem פ̧unde in bie $\mathfrak{A}$ ugen ge= fratzt."

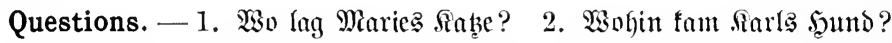

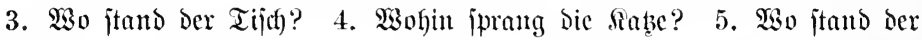

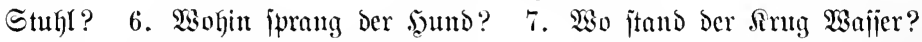

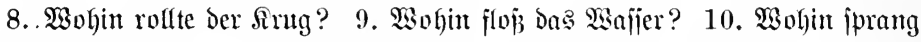

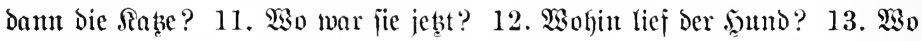
jtano ber Edrant? 14. Mso mar mod) Plats? 15. Fïr wen war Plats genug hinter dem Sdfraut? 16. Wo jtand mun ber şutus? 17. Wsobin

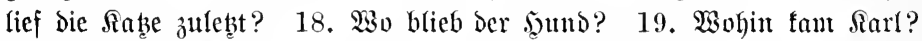

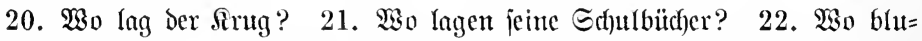

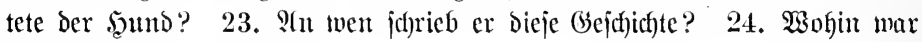
bie Sthwejter gejahren?

\section{DRILL}

State what case or cases each of the follouing prepositions govern: mit, an, durd), vor, von, fiit, ohne, neben, auper, zwiid)en, $\mathfrak{a u s}, \mathfrak{u m}$, gegen, hinter, in, nad), ïber, nebjt, unter, auf.

\section{WRITTEN EXERCISE}

1. Karl's school-books are lying on the table. 2. He laid them on the table. 3. The cat is in my room; she is lying upon the bed. 4. She sprang upon the bed. 5. He poured 
the water into the jug. 6. The water is in the jug. 7 . The water flowed from the table onto the floor. 8 . The jug is on the floor. 9. I placed the jug on the floor. 10. The cat ran between the cupboard and the wall. 11. The cat is behind the cupboard. 12. The $\operatorname{dog}$ is in the room under the bed. 13. I placed the chair against the wall. 14. He is sleeping on the bed. 15. The bed stood behind the cupboard. 16. Put the bed behind the table. 17. He stood at the door. 18. She went to (an) the door and closed it. 19. We went to (and) the window and saw him in the street. 20. We remained in the city, but the children went into (aur) the country to their uncle's. 21. He came ont of the house and went into the garden. 22. He wrote to me ahout the affair. 23. She spoke with her mother about the story. 24. There is room here for the bed, between the table and the wall. 25. He struck him on the head. 26. The cup rolled onto the floor and broke. 27 . We stood in front of the house.

\section{LESSON XXYIII}

95. Complex Sentences consist of independent clauses (also called 'principal', or 'main' clauses) and dependent clunses (also called 'subordinate' clauses). A dependent clause is one which depends on a principal clause for its meaning. Thus, in the sentence, "When I was in toun yesterday, I met your friend", the first clause is the dependent, and the second the independent, or principal clause. For "uhen I us in toun yesterday", by itself, is not a complete statement of a fact; it is dependent on "I mot your friemd" for its full meaning. Whereas 'I met your friend' "an stand alone, as a complete statement of a fact, and therefore is an independent or principal clause.

a. In German, a dependent clause is easily recognized by the posi- 
tion of the verb $(\$ 96)$. Such, however, is not the case in English; hence the importance of being able to recognize a dependent clause in English, when translating from English into German, so that the verb may be correctly placed.

96. Position of Verb in Dependent Clauses. - In dependent clauses the finite verb $(\$ 37,2)$ stands at the end of the clause ('transposed' word-order'):

T(s idf) gejtern abend nach Scauje fam, ging idf jofort $\mathfrak{j}$ Bett.

When I came home last night, I went at once to bed.

(1) If the verb in a dependent clause is in a compound tense, then the auxiliary stands last; the past participle or infinitive standing before it:

Rachbem idh gejtern abent nach şauje gefonmen war, bin idf jofort $\mathfrak{j}^{\mathfrak{t}}$ Bett gegangen, after I had come home last night I went to bed at once. Da ifh ifn morgen jeben werbe, werbe idf es ifn jagen. As I shall see him to-morrow, I shall tell it to him.

(2) If an infinitive accompanies the finite verb in a dependent clause, the same rule is followed:

Scil i(f) morgen nidft fommen fanu, gehe idh Jhnen bas (Seld.

Because I cannot come to-morrow, I am giving you the money.

97. The position of the verb in an independent clause, following a dependent. clause, is in inverted order; i. e. the verb first, then the subject (see examples above).

(1) As the whole dependent clause may count as one element, the rerb is in reality the second element in the entire sentence, according to the rule (see Lesson XV).

Compare these sentences:

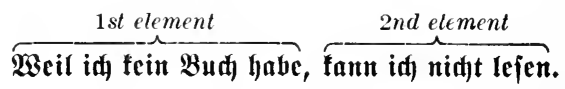

$\overbrace{\text { Dhute } \mathfrak{B u d}}^{1 \text { st element }} \overbrace{\text { famt id uid) lejent. }}^{2 n d \text { element }}$ 
98. Rules for the Position of the Verb.

I. In independent clauses the finite verb comes second.

2. In dependent clauses the finite verb comes last.

3. In independent clauses, following a dependent clause, the verb stands first.

Note. - The dependent clause is always separated from the independent clause by a comma.

99. Subordinating Conjunctions. - A dependent or subordinate clause is generally introduced by a subordinating conjunction or a relative pronoun. Hence, in clauses introduced by one of the following subordinating conjunctions, the finite verb stands at the end:

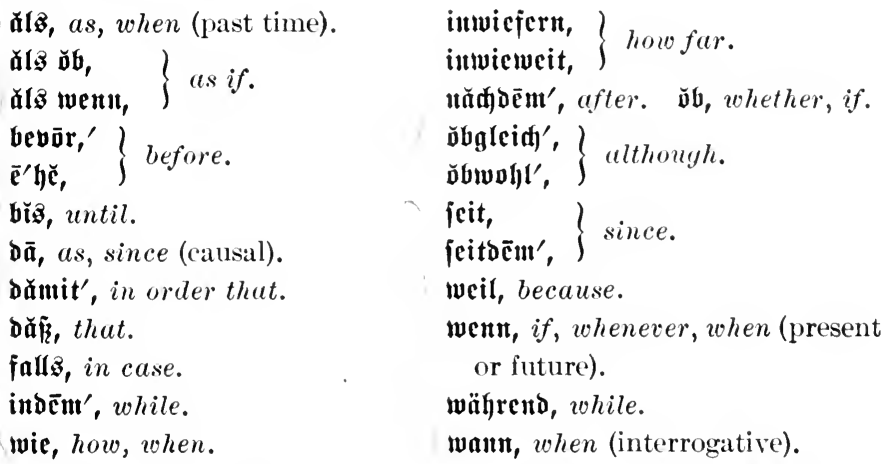

(1) $\mathfrak{A}$ (צ means ' $u \cdot h e n$ ', only when referring to the past:

Mls id) in Deutid)lant war, fprad id) Teutjd.

When I was in Ciermany I spoke German.

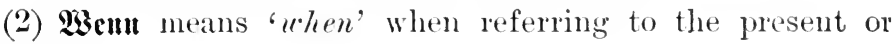
future:

Wienn id, morgen foume, jefhe iń Sic.

When I come to-morrow I shall see you.

It means 'whenerer' when referring to the past:

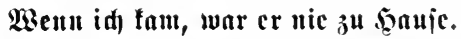

Whenever I came, he was never at home. 
(3) $\mathfrak{S a n u m ~ i s ~ i n t e r r o g a t i v e . ~ I n ~ a ~ d i r e c t ~ q u e s t i o n ~ t h e ~ v e r b ~}$ stands as in English:

\section{Siant foumen Sic morgen?}

When are you cominy to-morrow?

lint, in an indirect question, the verb stands last, because it is in a dependent clause:

Jd) weíz nirflt, wamn idf morgen fomme.

I do not know when I am coming to-morrow.

(4) The English ' $f$ ', in the sense of 'mhether', is $\mathfrak{o b}$ :

Jd weis uidgt, of cr fommen wirb.

I do not know whether (if) he will come.

Otherwise ' $f f$ ' is weun :

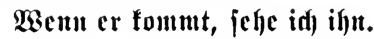

If he comes I shall see him.

(5) $\mathfrak{D a}$ expresses reason:

Da idy teine Zeit habe, fomme id midt.

As I have no time, I am not coming.

(6) The conjunction 'since', referring to time, is peit or jeit= $\mathbf{D e m}$; expressing reason, it is $\mathbf{b n}$ :

"Eeit er Gier war, habe ith) nidf)t vout ifm gefört.

I have not heard from him, since he was here.

Da mir Das Butth) nicht faben, füntent wir nid)t lejen.

Since we do not have the book, we cannot read.

( 7 ) Note that the conjunction 'after' is und) Dem, but the prepo sition is uad):

Yiadjoem er e马 gemadht fatte, gintg er fort.

After he had done it, he went away.

Er fam nad mir, he came after me. 


\section{VOCABULARY}

Das Ricb, -er, the song. verlie'ren, berlōr, verlōren, to lose. aus/jehen, jah aus, ausgefelgen, to

look, appear.

redft haben, to be right.

id habe redt, I ain right. id̛ făın, I can. er făun, he can. $\mathfrak{g} \overline{\mathfrak{a}} \mathbf{r}$, very, much. gāa nidjt, not at all. gāar nidjts, nothing at all. $\mathfrak{g} \overline{\mathfrak{a}} \mathfrak{r} \mathfrak{f} \mathfrak{c i u t}$, none at all.

\section{READING EXERCISE}

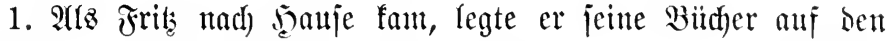
Tifdy. 2. Eeine Bitdfer jeben aus, als ob er viel arbeitete. 3. Ehe er jur Eafule gegangen inar, hatte er feine Echularbeit gemad)t. 4. Bleiben Sie ruhig hier, biz er morgen fommt! 5. Ia idf) gar fein (belo habe, fant id) bas $\mathfrak{B u d}$ nidyt faufen.

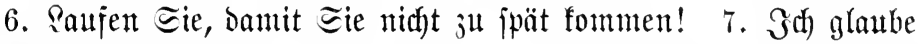
nidft, ba $\tilde{\beta}$ es heute regnen wirb. 8. Falls id Eie morgen nid)t jehe, jureiben Sie mir, bitte! 9. Inbem er fleipig arbeitete, jant er ein Kujtiges Sied. 10. Snwierweit er in ber Eache ("ff?"ir) red)t hat, werben wir morgen fehen. 11. Padjoem id ben Brief gejdrieben hatte, $\mathfrak{g a b}$ id) ifm denjelben. 12. Jeat er 3 hnen gejdrieben, ob er morgen fommen wirb? Sa, er hat mir ge= id)rieben, baj er morgen fommt. 13. Er jprid)t jehr gut Ieutid), obgleich er nur ein Gahr in Deutichland gemejen ijt. 14. Eeit= bem er in Deutidfland gemejen ift, ipridjt or immer Teutid). 15. Weeil er ein ganjes $3 a \mathfrak{l}$ r in Fentid)lanto gemejen ijt uno immer ba Teutid) gefprodjen hat, jo iprid)t er jeşt jebr gut Deutja). 16. Sisenn er morgen abeno nad) bauje foumt, jagen Sie ihm, bitte, baj id hier gemejen bin. 1\%. SEent idh fein Seld habe, fann id) Ghnen aud) gar nid)t geben. 18. Sisenn diejer Stubent (5elo bat, jo ijt er niemals zu פauje; aber wenn 
er gar feits hat, fo breibt er rubig ju Seauje und arbeitet fleip̈ig. 19. Sä̈hrend id) in ber Stadt war, regnete es.

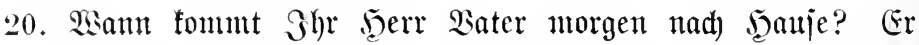
hat unz nid)t gejdrieben, wann er morgen nad) Şauje fommen wiro. 21. Wie er bie a(rbeit madhen wirb, ijt jeine Eadje uno nidht meine.

\section{DRILL}

A. In each of the follouring sentences rhange one of the coördinate clauses into a subrrdinate (or dependent) clause, by using a subordinating conjunction:

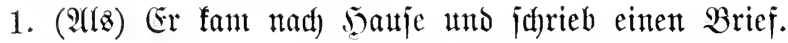

2. (Da) Sie hat fein (belo umb fann fein $\mathfrak{B u h}$ faujen.

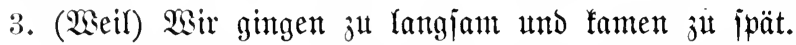

4. (พBährend)

5. (Obgleidf) Er hat bas (beld, aber er bejahlt nid)t.

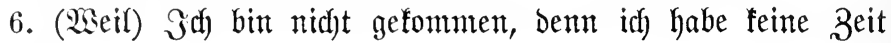
gehabt.

B. When is 'when' to be translated by als, when by weru, and when by want?

C. When is 'as' trunsluted by ale? When by ba?

\section{WRITTEN EXERCISE}

1. When I saw him yesterday, he was working diligently. 2. He looks as if he works too much. 3. Before he came to this town, he was very ill. 4. I remained there until he had written the letter. 5. As I have no book, I shall buy one. 6. Walk slowly, in order that you may not become too warm. 7. Tell him, please, that I am here. 8. In case you do not find the book, I shall buy a new one. 9. While he was talking, he held his old hat in his hand. 10. He will tell you (in) 
how far you are right. 11. After we had been in Germany, we spoke German. 12. I shall write you, whether he comes here or goes to New York. 13. If he goes to New York, I shall not see him. 14. He has not done the work, although he has had the time. 15. Since the poor man has lost his money, his children have helped him (dat.). 16. Pecause the father of this student gives him no money, he works very diligently. 17. Whenever I see him, he is witing long letters. 18. While I was in Germany, it was always raining. 19. When were you there? I was there when I was a little boy. 20. You have forgotten how often I have told you that.

\section{LESSON XXXIV}

100. Relative Pronouns and Relative Clauses. - Relative clauses, being dependent clauses, have the finite verb at the end:

Tie Trau, bie bas soun gefanjt hat, iit jeine Miutter.

The woman who bought the house is his mother.

(1) The relative pronouns are:

Singliar

Plural

Masculine Feminine

Neuter

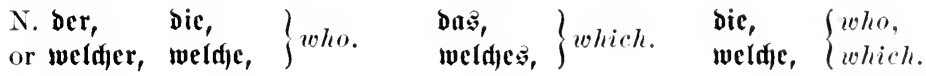

G. befïn, beren, whose. belien, of which. beren, $\left\{\begin{array}{l}\text { whose } \\ \text { of }\end{array}\right.$

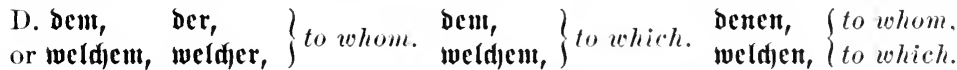

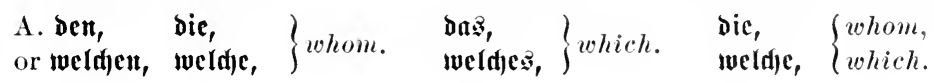

2. In simple style, bor is more usual than weldyer. Notice that Der, Die, Das as relative pronouns are declined like the definite article, excepting in the genitive singular and in the 
genitive and dative plural, where $\mathfrak{c}$ is anded. $\mathfrak{B e l d f e r}$, used as a relative pronom, has no genitive.

(3) The relative pronoun, as in English, takes its gender and number from the word to which it refers, but its case depends upon the construction in which it stands in its clause, thus:

(Er fat bem Sinaben, ber fier war, bas Buch gegebert.

IIe has given the book to the boy who was here.

Fer Inabe, beifen Bruber ar mar, the boy whose brother he was.

(4) The relative pronoun cannot be omitted, as in English:

Tas ijt nicht ber Manm, ben idf fah, that is not the man I saw.

(5) Like all dependent clauses, the relative clause is set off by commas.

101. Wier and $\mathfrak{B a n}$ as Relatives. - $\mathfrak{B e r}$ and was are generally used as interrogatives. $\mathfrak{B e r}$, however, is used as a relative if there is no preceding noun to which it refers:

Saer bas gejugt hat, iprad) bie $\mathfrak{B a f y r h e i t . ~}$

I'hoever (he who) said that spoke the truth.

Эđ) weip nidht, wer bier ijt, I do not know who is here.

But:

Id) fenue ben Miann, ber hier ijt, I know the man who is here.

(1) $\mathfrak{S} \mathfrak{a} \mathfrak{a}$ is used as a relative:

a. If it refers to a word having a general or indefinite meaning, as: alles, nichts, vielez, mandhes, ete:

(Er Gat alles, was cr Gatte, verforen, he has lost all that he had. Manthes, was er jagte, war wafr, much that he said was true.

b. If it refers to the whole of a preceding clause, as:

(Er hatte jeine Srbeit gut gemadft, was jeinen Bater fehr erfreute. He had done his work well, which pleased his father yery much. 
102. WBomit, worauf, etc. - Instead of a preposition, standing before a relative or interrogative pronoun referring to an inanimate object, a compound of the preprosition with wo or wovr is generally used, as: morauf' (on whirh), worin' (in which), woran' (aguinst which), womit' (with which), ete.:

Das batte, worin er wofnte, the house in which he lived.

Der Etuffl, wormij er jaj, the chair on which he sat.

Die Feber, womit er jotrieb, the pen with which he wrote.

103. In all dependent clauses, especially in relative clauses, the auxiliary of a verb in a compound tense may be omitted :

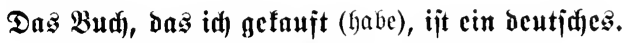

The book which I bought is a German one.

Madjbem er ben Bricf gelejen (hatte), jteftecte cr ifh in bie Tajadje.

After he had read the letter, he put it into his pocket.

\section{VOCABULARY}

die Rĕffnutg, -ent, the bill, account.

bie Edutei'bcrin, -nen, the dressmaker.

bic $\mathfrak{B a ̈ j} \mathfrak{j} \mathfrak{c}$, the wash, linen. bie $\mathfrak{i} \mathfrak{a} \mathfrak{h r h e i t}$, -ell, the truth.

Leute, die (pl.), people.

lï̄gen, lōg, gelōgen, to lie, tell a lie. erfreu'en, to rejoice. brav, honest, good.

traurig, sad.

$\mathfrak{w a h r}$, true.

lahit, lame.

Dumm, stupid.

glitif'lidf), happy, lucky.

cìt'māl, once.

nidft ciumal', not exen.

wcut... a a d), even if.

\section{READING EXERCISE}

1. Die Red)nung Des Edyneibers, Der meinen 9iod gemad)t hat, ijt nod) nidft bejahlt. 2. Tas ijt நeerr Braun, befien

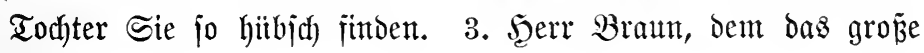


Sants gebört, ijt ein reidjer Mann. 4. Der Mann, den Eie geitern bei uns gejehen haben, ijt ein guter Maler. 5. Sït jie Die Frau, bie jo gut wäjht? Ga, jie ijt bie alte Frau, Deren

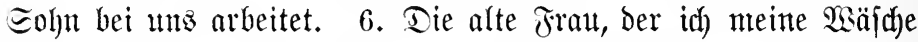
gebe, ijt eine brave Fraut. 7. Die Eanteiderin, bie Sie bei unz jahen, ijt ihre Todfter. 8. Taz Butd), weldyes id gelejen,

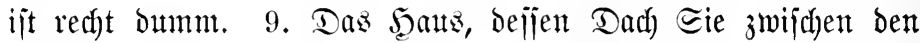
Bäumen jeben, ijt bas unjere. 10. Cin Sind, bem idh bie Sïpjel gab, jagte nid)t eimmal "Danfe." 11. Diejes Prero, weldhez idh geitern gefauft, geht heute (d)on lahm. 12. Die Miänner und Frauten, weldhe in bem Şauje wohnen, jint alle jehr arme Seute. 13. Die Simber, beren E.ltern jehr reiche Reute jind, jimb nidgt inmer bie glituflichjten. 14. Nieine Britber, benten idf es erjählt lyatte, jagten nichtz. 15. Die Reute, weldje Sie hier jehen, jint Deutjue. 16. Das Bimmer, worin er fdhlief, war red)t flein. 17. Ein Tijh), worauj viele Büdjer lagen, jtand bei Dem Bette. 18. Diejes $\mathfrak{B} u$ udf), wojiit idh brei Marf bejahlt habe, fojtet jełzt jedjo Marf. 19. Bieles, was id höre,

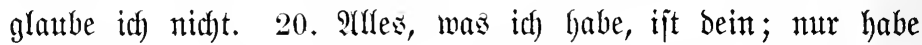
idf nidhts, waz viel wert ijt. 21. Эd) habe gar nidgt gefehen, wer da war. 22. "Wier einmal lïgt, dem glaubt man nicfit, und wenn er aud bie $\mathfrak{B a h r b e i t ~ ( p r i d ) t , " ~ i j t ~ e i n ~ a l t e z ~ S p r i d y w o r t . ~}$ 23. Diejez ijt bas Gnde der a(ujgabe, waz mid jehr erfreut.

\section{DRILL}

Supply the relative pronomen:

1. Der $\subseteq$ djitler, - fleişig arbeitet, lernt Deutfar. 2. Die Edjuilerin, - jat viel iprid)t, lernt gar nidftz. 3. Der Sehrer gat bem Miäod)en, - jo fleiphig arbeitet, ein $B$ utd) gegeben. 4. Der Mann, — Sohn jo franf ijt, hat viele Simber. 5. Diez 
ijt bie Frau, Mutter unjere $\Xi$ dneiberin ijt, ijt nur jed) Ba Gare alt. 7 . Ier Bauer, - bas ?anto gehört, ijt fehr reich. 8. Mieine Pehrerin, - id) bie S(urjgabe jeigte, lobte midf. 9. Ter giodf, - Eie haben, ijt der meine. 10. Der ভtuhl, - Sie jitien, hat meiner (jroßßmutter gehört. 11. 2iid)ts, - er jagt, ijt wahr. 12. Tie Sinder, - idh etwas (beld gab, waren hod) erfieut. 13. Tas jint bie Mütter, - Sinder in unjerem (barten fpielen. 14. Die Bütcher, - idh gefauft, waren biffig gemutg.

\section{WRITTEN EXERCISE}

N. B. Punctuate according to German rules $(\$ 100,5)$.

1. My father, who is a German, talks German with me. 2. My brother, whose dog has died, is very sat. 3. I have not seen the man to whom you have given the money. 4. There is the man whom we saw in the garden. 5. She is the lady whose little daughter is my friend. 6. The dressmaker to whom I gave the coat lives in our street. 7 . This bill which I am paying is for the coat. 8 . The bed which is in my bedroom is not big enough 9. This child whose father is our teacher is not stupid. 10. Are the books which are lying on the table mine or yours? 11. The parents whose children play in this garden are poor people. 12. The children to whom we had given the flowers said, "Thank you"! 13. Here is the bed in which he slept, and there is the chair on which he sat. 14. Is that the book for which you liave paid so much? 15. All that he says is true. 16. Much that he has written is the truth. 17. I did not even hear who said it. 18. I did not see the man who said it. 19. Even if he now speaks the truth, nobody will believe lim, for he has lied too often. 20. That is not the book I real. 21. The town where he now lives lies in South Germany. 


\section{LESSON XXXV \\ REVIEW OF LESSON XXVI TO XXXIV}

104. 1. Which vowels may take the 'umlant'?

?. How do nouns of the first class strong form their plurals? Name the endings of the maseuline and neuter nouns belonging to this class, illustrating by examples.

3. Name the two feminine nouns belonging to the first elass strong.

4. Of what gender are nouns ending in dyen and leiu?

5. Of what gender are most nouns that form their plural in "er?

6. Name three masculine nouns that form their plural in "er.

7. Of what genrler are most nouns in the weak declension?

s. Which masculine nouns form their plural according to the weak leclension? Illustrate by example.

9. Name three nouns which form the genitive singular strong, but the plural weak.

1). When is an accusative of time used; when a genitive of time? I'histrate in short sentences.

11. Of what gender are nouns ending in ci, heit, feit, fdjaft, ung, in?

105. 1. Which prepositions take the dative or the accusative? When do they take the dative? When the accusative? Illustrate in short sentences.

2. Which prepositions take only the accusative? Which only the dative?

3. Name two prepositions that govern the genitive.

4. Ifow should one translate $\mathfrak{u m}$ when followed by $\mathfrak{z} \mathfrak{u}$ with the infinitive?

5. When shoull one translate 'to' by $\mathfrak{j} \mathfrak{u}$ ? When by $\mathfrak{u a d}$ ?

6. When should one translate ' $b y$ ' by wout? When by bei?

7. When should one translate 'on' by ant? When by auf?

$\therefore$ Form German sentences to illustrate $4,5,6$, and 7 .

106. 1. What is an independent clause? What is a dependent dause?

‥ How can one recognize a dependent clause in German?

3. Give the principal rules for verb-position in German.

4. Name six suborlinating conjunctions.

5. Which subordinating conjunction expresses time in the past? Which, time in the present or future? 
6. When should one translate ' $f f$ ' by wenn? When by $\mathfrak{v b}$ ? Illustrate this and 5 in sentences.

107. 1. Where does the verb stand in a relative clause?

2. Decline ber, bie, bna as relative pronouns.

3. Mention a use of the comma in German, which does not always correspond with the usage in English.

4. When is wer used as a relative pronoun? When was?

5. When can the auxiliary verb be omitted in German? Illustrate by example.

\section{$\mathbb{L}_{\mathfrak{e}} \mathfrak{e}$ it ï if e.}

\section{Wand'rers 2raḑtlied.*}

ülber allen Bipjeln

Эit $\Re \mathfrak{i t h}$,

Эn allen $\mathfrak{B i p f e l n}$

4

Epitiejt but গaum einen şautd);

Die Böglein jafweigen im $\mathfrak{B a l b e .}$ Warte nux, Galbe গithejt but audf).

* Wanderer's night-song. ${ }^{1}$ tops, peaks. ${ }^{2}$ rest, calm. ${ }^{3}$ tree-tops. ${ }^{4}$ detect. ${ }^{5}$ scarcely. - breath. ${ }^{6}$ are silent. ${ }^{7}$ wait.

\section{Sdhwalbenlied.*}

Âtz jernem Rano,

Bom Mieeresitrano,

Iuf hoben luftigen $\mathfrak{B}$ egen

Fliegjt, Edswalbe, out

Shne Tiajt und Miull

6

Der lieben şeimat entgegen.

$\subseteq$ iprich, moher

über ?and und Wieer

Sajt du bie Siunde vernommen, 


\section{Dá̃ im șeimatland}

Der sinter janmanto,

12

llno ber Friil)ling, der Frïhling gefommen?

Dein Piebohen iprid)t:

Beiñ jelber nid)t,

Woler mir gefommen die Mahnung;

Dod) fort und fort,

Bon Drt ju Drt

8 Podt mid) bie Frïllingåanung.

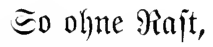

Эn freudiger sajt,

2 I

?uf́ bohen luftigen 2 segen

Flieg' idf unverwandt

Dem Seimatland,

24

Tem lenjgeidnuidften, entgegen.

Theodor Єtorm. (1817-1888.)

* Swallow song. ${ }^{2}$ ocean's shore. ${ }^{3}$ airy paths. ${ }^{5}$ rest and repose. ${ }^{6}$ towards the dear native land. ${ }^{7}$ whence. ${ }^{9}$ news, - heard. ${ }^{11}$ disappeared. ${ }^{12}$ spring. ${ }^{14} \mathrm{I}$ do not know myself. ${ }^{15}$ reminder. ${ }^{16}$ continually. ${ }^{18}$ entice.- anticipation of spring. ${ }^{20}$ joyful haste. ${ }^{22}$ steadily. ${ }^{24}$ towards the one (the native land) spring-adorned.

\section{Llmfonft lebert. ${ }^{1}$}

Am Mibein lebte einmal ein armer snahe mit jeiner Matter. Ter Bater war gejtorben, als ber Sinabe nod) ganj flein war. Dafer ${ }^{2}$ ginty der sinabe friil) an die s(rbeit uno half jeiner Mutter ihr Brot ju berbienen. ${ }^{3}$ Ia er gut ruberte ${ }^{4}$ und jegelte, jetzte $^{6}$ er seute ïber ben Mhein in einem Boote, welchez er von jeinem Sater geerbt hatte. Eines Tagez, alz ez ziemlich

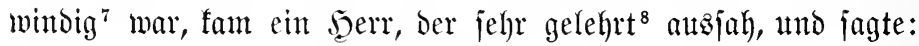

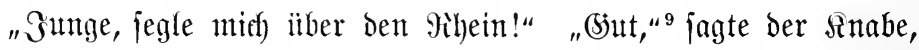
"jteigen ${ }^{10}$ Sie mur ${ }^{11}$ inz 2 bot!“ Der Deerr jtieg ein und bald

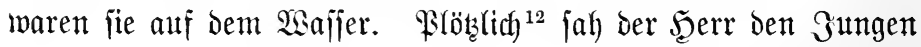


icharf ${ }^{13}$ an ${ }^{14}$ und fagte: "Jutnge, fammit du rejen?" "Piein," jagte ber Gunge. "Dann hajt on ein Wiertel ${ }^{15}$ beintes Sebens umponjt gelebt," jagte ber beerr. Ter $\Omega$ nabe jah bett berrm jebre erjtaunt ${ }^{16}$ an, jah jidh Dann um ${ }^{1 \bar{r}}$ und jagte: "Jdh glaube, mir befommen mehr Waind." S(ber ber gelehrte berr börte nidht auf ben Gumgen, ${ }^{18}$ jonbern fragte meiter: ${ }^{19}$ "Juntze, fannjt bu jahreiben?" "ilein," jagte Der Bunge. "Dann hajt

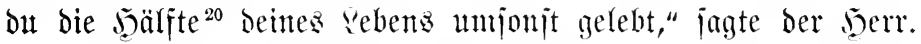

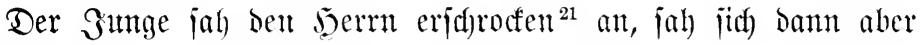

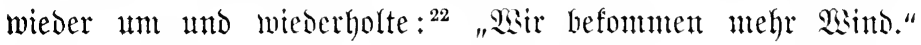
Aber ber seerr jahl ihn mut mitleisig ${ }^{23}$ an und jagte: "sammjt Dut red)nent"? ${ }^{24}$ S(lB ber Gunge jum brittemmal ${ }^{25}$ "Piein" jagte, idrie ${ }^{26}$ Der beerr: "Tann hajt du brei Siertel Deinez Sebents umjonjt gelebt!“ Bei biejen Bisorten erjofraf ${ }^{2 \pi}$ ber arme Gunge jo jehr, ba $\tilde{\mathfrak{B}}$ er nicht auj jein Eegeln adhtete, ${ }^{28}$ ein heftiger ${ }^{29}$ Wind fam, das Boot jhlug umb umb ber fluge beerr uno ber Dumme Gunge lagen beibe im Siafjer. "siönten Eie jalwim= men?"s1 rief ber Sunge bem flugen beerm ;u. "Piein," war die 9 (ntmort. "Piach, ${ }^{32}$ bann haben Eie aber $3 \mathfrak{h r}$ ganjes Seben umjonjt gelebt!" riej ber Gunge und idjwanm ans Sant.

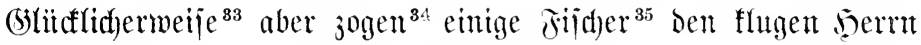
nod) zeitig gemug ${ }^{36}$ atts bem sisalier.

${ }^{1}$ living in vain. ${ }^{2}$ therefore. ${ }^{3}$ earn her (bread) living. ${ }^{4}$ rowed. ${ }^{5}$ sailed. ${ }^{6}$ put. ${ }^{7}$ rather windy. ${ }^{8}$ learned. ${ }^{9}$ All right. ${ }^{10}$ get (in). ${ }^{11}$ just. ${ }^{12}$ suddenly. ${ }^{13}$ sharply. ${ }^{14} \mathfrak{f a b} \mathfrak{a} \mathrm{n}=$ looked at. ${ }^{15}$ a (quarter. ${ }^{16}$ astonished. ${ }^{17}$ looked around. ${ }^{18}$ listened to the boy. ${ }^{19}$ further. ${ }^{20}$ the half. ${ }^{21}$ frightened, st art led. ${ }^{22}$ repeated. ${ }^{23}$ compassionately. ${ }^{24}$ reckon, count. ${ }^{25}$ for the third time. ${ }^{26}$ shouted. ${ }^{27}$ was so startled. ${ }^{28}$ did not pay attention to his sailing. ${ }^{29}$ violent. ${ }^{30}$ capsized. ${ }^{31}$ swim. ${ }^{32}$ Well! ${ }^{33}$ luckily. ${ }^{34}$ drew. ${ }^{35}$ Several fishermen. 36 'yet timely enough', i.e. before it was too late.

Questions. - 1. Siso Yebte ber arme finabe? 2. Sisarmm ging ber

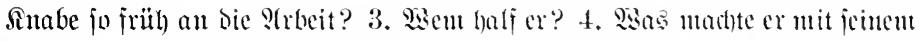

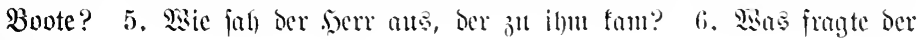


Deerr Den Sunaben? 7. Sarmu ad)tete ber Junge nidft anf fein Segeln?

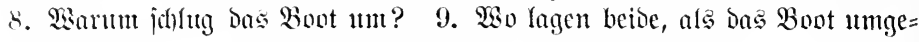
jh)lagen war? 10. WSas rief ber Junge mu Dem serm zu? 11. Wobin (d)wanm ber Junge? 12. Was madhten einige Fijher? 13. Erzählen Sic bieje (bejchicfte!

\section{DRILL}

A. Give the dependent cluuses in this story.

B. Give the principal parts of as many of the strong verbs as you can.

C. Change the past tenses into present tenses.

D. Give the separable prefixes that occur in the story.

E. Give the mepositions, and state what case or cases each governs.

F. State which nouns, occurring in the story, belong to the weak declension.

\section{LESSON XXXVI}

108. Separable Verbs in Dependent Clauses. - In dependent clauses, the prefix of a separable verb is not detached from the verb. The prefix and verb stand at the end of the clause as one word:

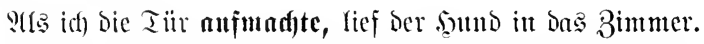

IThen I opened the door, the dog ran into the room.

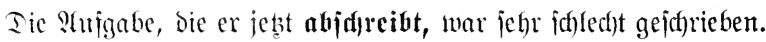

The exercise which he is now copying was very badly written.

109. Demonstrative Pronouns. - Der, bie, bas, besides being definite articles and relative pronouns, can also be demonstratives. As demonstrative adjectives or pronouns they are inflected like the relative Der, Die, Daz $(\$ 100)$. They are distinguished, first, from the article, by greater stress in pro- 
nouncing; and second, from the relative, by the position of the verb, as:

(1) Rennen Sic bē⿲彳 Miann? Do you know that man?

(2) Es war einmal cin Sïnig, bēr' hatte cinte Todhter. There was once a king, and he had a daughter.

But, Gs mar eimmal ein fïnig, ber eine Tod)ter hatte. There was once a king, who had a daughter.

a. Notice in (2) that the demonstrative may be used while in English the personal pronoun is used.

110. The neuter singular forms, biejes (bies), das, and es, are used without inflection as subjects of the verb jein; the verb, however, agreeing with the following noun, thus:

Dics jint meine Bürfer, these are my books.

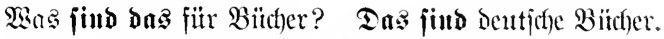

What kind of books are those? Those are German books.

Şicr jind brei Bücher. Ga jiut Deutiche Büther.

IIere are three books. They are German books.

111. Der, bie, bas, and es, referring to inanimate objects, are rarely used with prepositions, a compound of the preposition with $\mathfrak{d a}$ or $\mathfrak{d a r}$ being used, as: Damit', Dafiir', barin', bar= $\mathfrak{a} \mathfrak{u} \mathfrak{f}^{\prime}$, etc:

Das $B$ bud lag barauf, the book lay on it (thereon).

Jat habe brei Miarf bafiir gegehen, I gave theree marks for it.

112. The demonstrative adjectives bicfor and joucr are also used as pronouns, biefer in the sense of this one, the latter, jener, that one, the former:

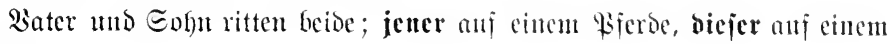
Ejel.

Father and son both rode; the former on a horse, the latter on " donkey. 


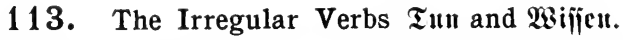

tūin, tāt, getāut, to do.

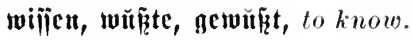

\section{Present Tense}

idi) tūte, $I$ do.

bu tīit, thou doest, you do.

cr tüt, he does.

wir tīult, we do.

ifhr tàt, you do.

fie tūn, they do id) weiriz, I know.

bī wci $\tilde{z}_{\mathrm{Z}} \mathrm{t}$, thouknowest, youknow.

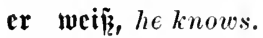

wir wifien, we know.

ifgr wifizt, you know.

jic wifien, they know.

Past Tense: iđh tāt, I did.

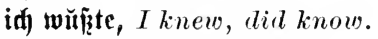

Perfect Tense: idf habe getāu, I have done.

id $\mathfrak{h a b e} \mathfrak{g e w n ̃} \tilde{z} t$, I have known.

(1) Tun is not used as an auxiliary (as in English):

Did you write the letter? Saben Eie ben Bricf gejorichen?

I did not go, ich) bin nicht gegangen.

(2) Madhen is very frequently used for tun:

$\mathfrak{a}$ כ mad)u Sie, or was tul Sie? What are you doing?

(3) Wiffen means 'to knou', to have learned, to have acquired knowledge'; fennen means 'to know', to be acquainted with'. Hence wijifen is used of facts and statements; fennen, of persons and things, as:

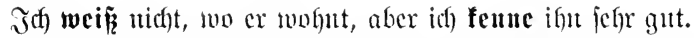

I do not know where he lives, but I know him very well.

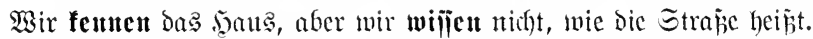

We know the house but we do not know the name of the street.

a. A practical rule is to use fenten when the direct object is a noun, or a pronoun standing for a noun, and to use wifien when the direct object is a clause, or a pronoun standing for a clause, thus:

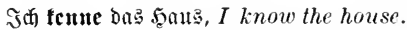

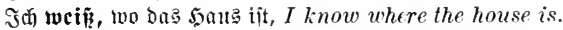

Wiffen Sie, wo er iit? Do you know where he is? 


\section{VOCABULARY}

Dcr $\Re$ öutig, -e, the king.

ber $\mathfrak{B u ̈ b e , ~ - n , ~ t h e ~ b o y . ~}$

ber Etreid), -e, the trick

ber ßrcis, -e, the price.

Die $\Re \ddot{b}$ 'nigin, -Iten, the queen.

Dic Flicge, -n, the fly.

$\mathfrak{D a} \mathfrak{B} \mathfrak{S} \mathfrak{a} \mathfrak{a}$, -e, the hair.

bå Mlär'd)en, 一, the fairy-tale.

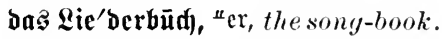
bas $\mathfrak{B o l f}$ slied, -er, the folk-song. feututen, farunte, gefănnt, to know, to be acquainted with.

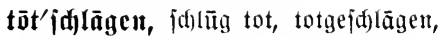
(er fdulägt tot), to kill.

ğolden, golden.

fdilimut, bad.

$\mathfrak{n} \mathfrak{S}^{\prime}$ wendig, externally, by heart. aus'wendig wiijen, to know by heart.

nid)ts als, nothing but.

\section{REAADING EXERCISE}

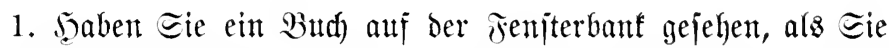

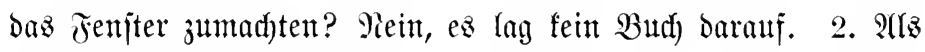
idf in bas 3immer lineintrat unt bie Tïr hinter mir jumadhte, jah idf ein Budf, bas lag auf dem Tijh. 3. Sal habe bas Bud) gehabt uno barin gelejen. 4. Es war einmal ein Ednei= Der, ber hatte jieben Fliegen totgeidflagen. 5. Samit hat er bie totgeidhlagen? Er nahm ein Ettilf Tudh unt bamit julug er jie tot. 6. $E s$ war einmal ein mumberjajönes Mä̈bden,

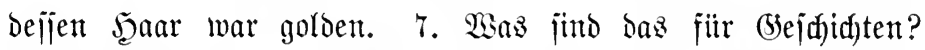
Daz jüb alte beutiche Märdyen, bie habe id als Rimb gelejen. 8. Sd) habe ein altes $\mathfrak{B} \mathfrak{u}$ ), Darin jtehen wunderidjöne Miärdhen.

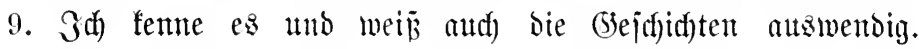
10. Das Budf), meldyes er uns in ber Etabt faufte, war ein beutiches Pieberbuth. 11. Er hatte mur eine Marf bafitr gegeben. 12. Gs waren bentiche Solfstieder barin, bie jingen wir oft. 13. Es waren jwei $\mathfrak{B u b e n , ~ d e r ~ f l e i n e ~ M a x ~ u n o ~ o e r ~ g r o ̈ ̈ e ~ M o r i z , ~}$ biejer war jaflimm uno jener nod) fdhlimmer. 14. Was haben bie getan? Tie haben nidhts als dumme Etreidje gemadht. 


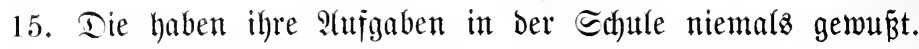
16. Geber im Torje tannte die, foldhe jallimmen Buben maren es! 17. Siennen Eie nid)t Das Bud "Maac und Moritz"? Gebes

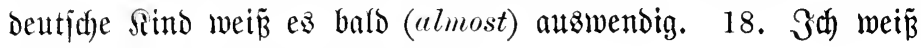
nidgt, ob id) ez fenne ober nidht.

\section{DRILL}

A. Change the demonstrative pronouns into relatives, by changing the position of the verb, in sentences $2,4,6,7,12$ of Reading Exercise.

B. Supply wijien or fennen in the following sentences:

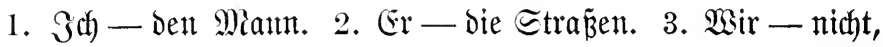
wo er wohnt. 4. - Sie die Mamen der Strä̈en? 5. - Sie,

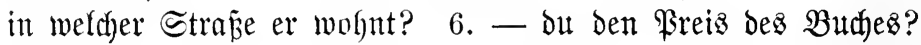

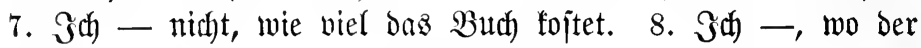
Brief ijt. 9. (Er - mid) nidft, aber idf -, wer er ijt. 10. Эa) - ১ås Rieb, aber id - ez nid)t ausinendig.

C. Give the future tense of wifijen and tun.

D. Decline Der, die, Daz as demonstrative pronouns.

\section{WRITTEN EXERCISE}

1. When I was going out, he opened the door for me. 2. She is very sad, because you are going away. 3. The little dog which barked at me is lame. 4. Because the sun was setting, we went home. 5. If you get up now, you will have time to do it. 6. There was once a queen and she had a daughter, and she was very beautiful. 7. Are those your books? Yes, they are mine. 8. Who are those girls? They are my sisters. 9. How much did you pay for the copy-book? I paid five cents for it. 10. Was the dog on the bed? No, he was lying under it. 11. The teacher has two children, a son and 
a daughter (acc. of aplosition); the former is ten years old and the latter only three. 12. What are you doing? I am doing nothing. 13. I know that you are doing nothing. 14. I know that song-book and I know the songs in it by heart. 15. Do you know where he lives? He lives with his father. 16. These bad boys play stupid tricks. 17. That tailor who killed the seven flies was only a little man. 18. Every child knows Grimm's fairy-tales by heart. 19. The have a ferman songbook at home, and in it are beautiful German songs. 20. I do not know whether he is a German, but he speaks German very well (ght).

\section{LESSON XXXVII}

114. Irregular Weak Verbs. - The following weak verbs change the stem vowel $\mathfrak{c}$ to $\mathfrak{a}$ in the past indicative and in the past participle; otherwise they are conjugated like regular weak verbs:

INFINITIVE

$$
\text { PAsTT - PAst PiRTiciple }
$$

(1) Grĕnnen, to burn. i(f) brănnte, I burnt. gebrămnt, burnt. fěrnen, to know. i(f) fămnte, I knew. gefănnt, known. nĕnuen, to name, call. idh) uămnte, I named. genăınt, named. rěmuen, to run, race. iff) rămnte, I ran, raced. gerămnt, (iijt), run, raced. fenten, to send. (iđ) jănote, I sent. gejăntot, sent. menben, to turn. idh mănde, I turned. gemănot, turned.

(2) The two following also change the consonant: bringen, to bring. idf) bră(t)te, I brought. gebrăat)t, brought. Denfen (an, acc.), to think (of). idi) iăchte, I thought. gebă(ht, thought.

Perfeco Tense: iđ habe getăınt, I have knoun. id) habe gebăd)t, I have thought, (2t).

115. Present Participle. - The present participle of all verbs (strong, weak, and irregular) is formed by adding $\mathbf{D}$ to 
the infinitive, or cur to the stem, as: ipielen, to play, fpielcurd, playing; brennen, to burn, brennend, burning; fabren, to travel, fahretio, traveling.

Noте: Exceptions are feient, being; and tnend, doing, from fein and tun.

(1) The present participle is not used to form a progressive form, as in English, this being expressed by the simple verbform:

I am playing, idh fpicle; it was burning, $\mathfrak{e}$ branute.

(2) The present participle is mainly used as an adjective, and is inflected as such, hence:

¡pie'lento Simber, playing children.

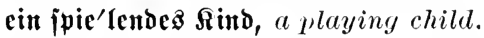

$a$. The present participle, declined like an adjective and preceded

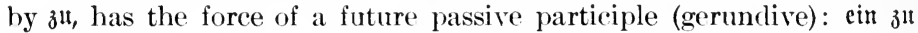
bau' little used in colloquial speech.

116. Verbs ending in ieren are, for the most part, formed from other languages. They are conjugated weak, but do not take $\mathfrak{g} \mathfrak{c}$ in the past participle:

ftudie'ren, to study; $\quad$ inf habe ftubiert', I have studied. telephonie'ren, to telephone; id habe telephonicrt', I have telephoned.

117. Omission of $\mathfrak{b a r}$. - As in English, the subordinating conjunction $\mathfrak{d} \mathfrak{a} \tilde{\mathfrak{B}}$ (that) may be omitted after verbs of saying and thinking; in which case the position of the verb is the same as in main clauses (notice use of comma):

Jad glaube, er wirs morgen $\mathfrak{z} \mathfrak{h} \mathfrak{5} \mathfrak{a} \mathfrak{j} \mathfrak{e}$ jein.

I believe (that) he will be at home to-morrow.

Id benfe, wir maden bie $\mathfrak{T r b e i t}$ heute.

I think (that) we will do the work to-day. 


\section{VOCABULARY}

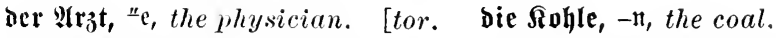

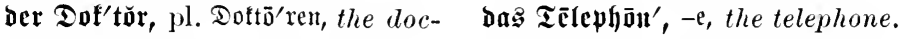
Der $\bar{D} \mathfrak{i e n}, *$, the stove, oven. ber Cinter, -, the bucket, pail. Die Télephōn'nummer, -n, the telephone number.

die Jeuerwehr, -ent, the fire brigade, fire-department.

Die Sranf'heit, -en, the illness.

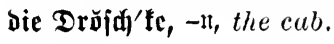

bas Feucr, 一, the fire.

turie'rell, to cure.

fubie'ren, to study.

‘̈jiden, to extinguish.

ver $\left.\mathfrak{j} \overline{\mathfrak{u}}^{\prime} \mathfrak{d}\right) \mathfrak{e n}$, to try, attempt.

laduen, to laugh.

¡d)uell, quick.

$\overline{\mathbf{e}}^{\prime} \mathfrak{b e} \mathbf{H}$, just.

\section{READING EXERCISE}

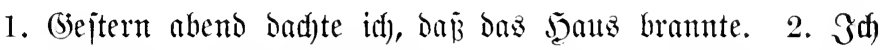
janbte Jritz ju unjerem Siadbar, ben idf jebr gut fenne, uno

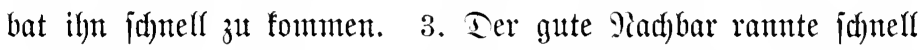
itts $\mathfrak{5} a \mathfrak{s}$ und löjhte das Feuer mit jwei ober brei Cimern Kafjer. 4. Warum laaben Eie nidgt an bie Jeuerwehr telepho= niert? Seil wir fein Telephon in .̧auje haben. 5. Wo war das

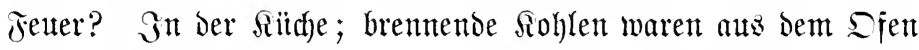

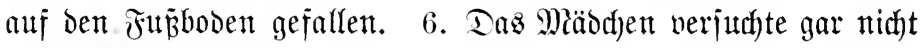
bas Feuter ju löjhen, jondern rannte aus dem Şauje. 7. Mein Sater und meine Matter waren nidht ju Sauje, jie bradten eben unjeren (brofjuater in einer Trojdfe nadh ந̧auje. 8. Tie Siranflyeit des (5rojpaters ijt johlimmer geworden, er fann nidft

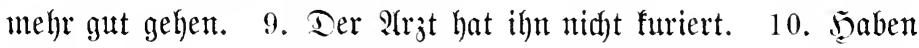

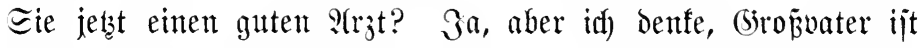
jajon jut alt und wiro nicht befier. 11. Saza ijt bie Telephon=

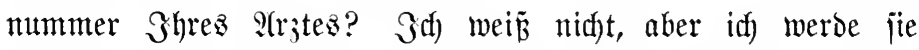
§hnen fenden, wil haben fein Telephonbuth im 5̧auje. 12. Ter Seer Toftor Braun ijt ein fehr guter 9 (rjt und ein fehr freund= 
firfer Wian, er bat meinen Sater von ciner joberen Siranfleit furiert. 13. SGo hat er jubiert? $\mathfrak{G}$ d) glaube, er hat in Sceidel berg jtubiert. 14. Er hat meinen Sater idjon lange gefannt; idh glaube jie haben oa jujammen jtubiert.

\section{DRILL}

A. Give all tenses of: Daz Fetter brennt; id fenne bie Dame nitht; er nenut ily einen guten Sungen; bringen Eie ihr ben Briej?

B. Translate: the burning house; a burning house; burning houses; the playing boy; the laughing child; my laughing children.

C. Omit baj in the following sentences, and alter position of cerl accorlingly: 1. Er benft, Da $\tilde{\beta}$ er morgen fommen fann. 2. Эa) glaube, baj es morgen regnen wird. 3. Sie hofft (hopes),

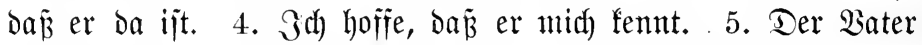

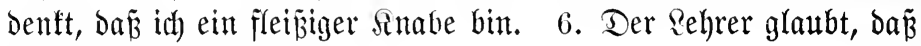
wir alle fleiñig arbeiten.

\section{WRITTEN EXERCISE}

1. The kitchen was burning, but we extinguished the fire with a few buckets of water. 2. He sent Hans to me and begged me to come quickly. 3. I ran into the house and telephoned to (an) the fire-department. 4. The fire was out when the fire-brigade eame. 5. My father is ill, and I have telephoned to the doctor. 6. I think he will soon be here. 7. We brought father home in a cab; he was too ill to walk. 8. The physician has cured him before (friiher), and I think he will cure him now. 9. The illness has not become worse. 10. We have known our physician six or seven years. I believe my brother studied with him in Berlin. 11. My brother had studied already two years in America when he went to Ger- 
many. 12. Travehing sturlents brought my brother a beautiful picture of (bon) Heidelberg, which an old friend had sent him.

\section{LESSON XXXVIII}

118. Genitive of Personal Pronouns.

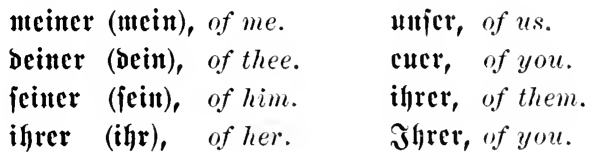

(1) The genitive of the personal pronouns oceurs chiefly as the object of a verb governing the genitive case, as: idf erinnere midf $\mathfrak{J y r e r}$ I remember you. It also occurs with prejositions governing the genitive case, as: anjtatt utcincr, instead of me.

a. The older forms mein, bein, etc. occur mostly in poetry, as: idf Denfe bein, I think of thee; vergin nirgt mcin! forget me not. Most of the verbs, however, which formerly governed the genitive, now require the accusative or a preposition, thus: iff dente ant biff, I think of thee: bergí mind nitht, forget me not.

b. The prepositions $\mathfrak{h a l b e n ,}$ wegen, willen (for the sake of $)$, which govern the genitive case, form compounds with the genitive of the personal pronouns, the ending $\mathfrak{r}$ of the latter being changed to $t$, as: meinetwegen, for my sake; beintwilfen, for your sake; feinthalben, for his sake, ete.

\section{The Reflexive Pronouns.}

(1) The reflexive pronouns of the first and second person are the same as the personal pronouns, thus:

idh twajd)e ntid), I wash myself. Iwir majhen uns, we wash ourselves. bu mäj(d) bid, thou washest thyself. ihr maj(het euth, you wash youselves. 
(2) The third person singular and plural has, however, a distinct form, fidf. Thus jidf) may represent the English himself, herself, itself, themselves, and (if the pronoun is $\Xi_{\text {ie) yourself: }}$

Er jebtit fid, he seats himself; jie jebt fid, she seats herself. Seţen Sie fid)! sit down.

(3) Moreover, jidf may be dative or accusative, as:

Err hat fid (dat.) Das Butd) gefouft, he bought the book for himself. (Er wäj(ht fith (acc.), he washes himself.

(4) The reflexive pronouns may also be used in the sense of each other, one another, as:

Sie lieben fidy, they love one another.

Bir veritehen una, we understand each other.

(5) The English emphatic -'self' is jellojt:

(Er hat $\mathrm{e}$ 马̧ felbjt getan, he did it himself.

Selbit, standing before the word emphasized, is the English 'even':

Gelbjt er war ba, even he was there. But, Ér jelbit war ba, he was there himself.

120. Reflexive Verbs. - The reflexive verb expresses an action which is performed by the subject of the verb upon itself, as: idh lege midh hin, I lay myself down.

(1) There are two kinds of reflexive verbs:

Those which are always accompanied by a reflexive pronoun, as: jith) befinden, to be; jidf beeilen, to hasten.

Those which may, or may not be accompanied by a reflexive pronoun, according to the meaning; i.e. are sometimes reflexives, and sometimes not, as: jifh wajd)en, to wash oneself (but das Rind wajhen, to wash the child).

a. Reflexive verbs are used far more in German than in English. 
Those of the first kind are given in vocabularies with fith before the infinitive.

$b$. Most reflexive verbs take the reflexive pronoun in the accusative, as: idf jetze mid), I sit down. If however the verb, when not used reflexively, governs the genitive or dative, the reflexive must likewise be in the genitive or dative, as: id) helie mir, I help myself; er filfit jid, (dat), he helps himself.

c. A transitive verb, used intransitively in English, becomes reflexive in German :

Id) öfite bie Tïr, I open (tr.), the door.

Die Tür öfincte jid), the door opened (intr.).

(2) All reflexive verbs take haben as the auxiliary and show no peculiarity of conjugation; the reflexive pronoun taking the usual place of the object pronoun.

\section{INFINITIVE}

fid crin'nern, to remember.

jid) ein'bilben, to imagine.

\section{Present Texse}

id) erin'tuere nidd, I remember.

id) billoe nir cin, I imagine. Du erimerit bid), thou rememberest. Du bildojt bir cin, thou imaginest. er erintmert jid), he remembers. cr billoct jid) cint, he imagines.

wit erintern uns, we remember. wir bilben uns cin, we imagine. ifr crimert cudf), you remember. igr bilbct cutr) cin, you imagine. jie crimnern jid), they remember. Sie erinnern fid, you remember. jie bildon fidy cin, they imagine. Sie birloen jidt cin, you imagine.

Past Tense: idf erinnerte mid, I remembereal. id) bilbete mir eill, I imagined.

Perfect: idf habe midf crimuert, I have remembered. idf babe mir cingebiloct, I have imagined.

Pluperfect: id) hatte mid erinnert, I had remembered. id) hatte mir eingebildet, I had imagined.

Future: idh werde mid crinnern, I shall remember. id) werbe mir cinbiloen, I shall imagine. 


\section{Future Perfect}

id) werbe midh crimert haben, I shall have remembered.

id) werbe mir cingebiloct $\mathfrak{h a b e n , ~ I ~ s h a l l ~ h a v e ~ i m a g i n e d . ~}$

\section{IMPERATIVE}

crimtere Didf, remember.

crimert cud), remember.

crimnern Sic fith, remember.
Gilde bir cin, imagine.

bilbet cudf cin, imagine.

bilbent Sic jid) cint, imagine.

\section{VOCABULARY}

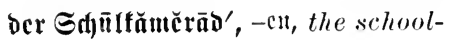
mate.

Dic Primjcifin, -nen, the princess. bas Empfangimmor, -, the reception-room.

(Eurō'pā, (baร), Europe. [(of). crin'ncru (aut, ace.), to remind jid freuen, to be ylad, rejoice.

jid) bee' $\mathbf{i}^{\prime} \mathbf{c t}$, to hasten, hurry. [be. (iid) befin'ben, befans, bejutsen, to jid $\mathbf{v e r h e i ' r a t e n , ~ t o ~ g e t ~ m a r r i e d . ~}$ (iid) ictzcn, to seat oneself, sit down. fid) crfun'sigen (mad)), to inquire (after). jetzen, to set, place, put. fitzen, jāis, gejeijen, to sit. verite'hen, veritano, veritanden, to understand.

$\mathfrak{g}^{\mathrm{r}} \overline{\mathrm{i}} \mathfrak{i} \mathrm{cn}$, to greet, bow. $\mathfrak{a} \mathfrak{s}$ 'rufen, rief atts, ausgerufen, to exclaim, call out.

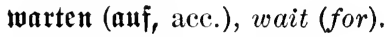
ein'gebildet, conceited. viclleidft', perhaps. prä df'tig, magnificent.

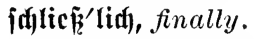
bejon'bers, especially.

\section{READING EXERCISE}

1. Der alte jerr Ehntost erinnert fith meiner, obgleich er midh jeit jebn Gabren nicht gejehen hat. 2. Gh freue midh jehr, baf er jich meiner erinnert. 3. Fr hatte eine hïbjhe fleine Todyter, idf erinnere midh ihrer jehr gut. 4. Ghretmegen labe id ben Bater oft bejutht. 5. Sie blieb meinetwegen immer ju j̧auje, wenn id fant. 6 . Sie frente jidh, mid zu jehen, benut jie war nodh ein sino. 7. Eelbjt alz groṕez Mäb= chen erinnerte jie jid meiner, and wir grïpten uns immer fehr 
freundlid auf der Strape. 8. Wie ofit haben wir uns als

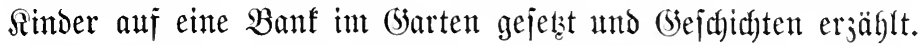
9. Ghrethalben erjählte idh nur lujtige (jejhidhten, Denn jie liebte die traurigen nidgt. 10. G(h) erjäh(te Miärchen von Prinzen

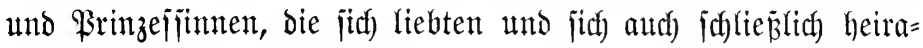
teten. 11. Wie oft hat jie jut mir gejagt: "Frtis, jełze bid) uno erzähle mir Märchen!“ 12. Cin Märchen liebte jie bejonders, daz Märchen von Den unartigen Sindern, bie fich niemalz mujchen und bod) glïff(id) waren. 13. Epäter war idh viele Gahre fort und alz idh wiederfam, hatte jie jidh verlyeiratet. 14. Эal be= eilte midh, jie zu bejudfen, aber jie beeilte jidf nid)t mid) ju jehen, benn ih habe lange im Empjangjimmer gejejien und gewartet. 15. Bielleidft mad)te fie jidh hitbich. 16. (Endida öffitete jidf bie Titr, und herein trat meine alte Frembin. 17. "Sie wirb mein Mann fich fretten, Sie zu jehen," rief jie aus, denn ilyr Mann war ein alter $\subseteq$ dhulfamerad von mir. 18. S(ber idf bilde mir ein, er wirb fidh nid)t bejonders freuen, benn wir waren niemals gute Freunde. 19. Er war immer ein eingebildeter Menich. 20. Wir bejanden uns in einem gropen Bimmer mit

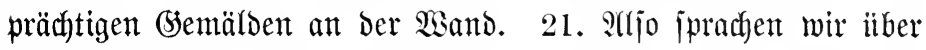
die Bilder, denn wir bilbeten uns ein, daj wir etwas bavon veritanden. 22. Wir haben unz aber jeitbem niemals wieber= gejehen, benn jie befindet jidf) junon jeit Gahren in Curopa. 23. Der alte Serr $\subseteq$ d)miot erinnerte midh an bie alten Zeiten, als ih ihn heute morgen jah.

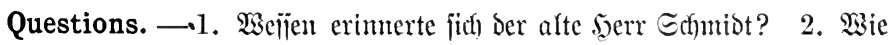
war feine Iodfter? 3. Weshalb (wherefore) hatte Der junge Mann Den Sater bejutht?. 4. Weşgalb Glieb bie Torfter ju banie? 5. Weijen erint=

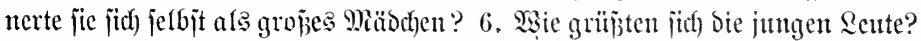

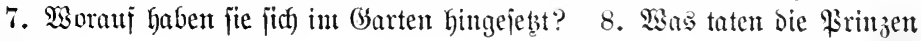


und \&rinjejïunen im Miärchen?" 9. Welches Miürdfen liebte Das Mäbchen bejonders? 10. Waas hatte das Miäbr)en getan, als ber junge Mann wie= Derfam? 11. Waas jagte jie, ala jie ins Binmer trat? 12. Wo befanden jie jidt)? 13. Was bilbeten jie jich ein? 14. Warum baben jie jid jeitbem nicf)t wiebergeiehen?

\section{DRILL}

A. Conjugate in past tense: jidf freuten, fid beeilen, fid) be= finden, jidh verheiraten.

B. Decline the personal pronouns.

\section{WRITTEN EXERCISE}

1. I remembered him, and he remembered me; for we were schoolmates together. 2. We were very glad to see one another. 3. He was glad to see me, and I was glad to see him. 4. For his sake I had gone to Berlin, and not for her sake. 5. We sat down (seated ourselves) and talked of old times. 6. I reminded him of the time when we were boys together. 7. He inquired after my sister and I hastened to tell him everything. 8. I said to him: "Perhaps you know that she has got married." 9. "I know that," answered he, "and I am glad for her sake, for her husband is an old friend of mine" (see 17 of Reading Exercise). 10. He has a magnificent house in the country, and she goes to Europe every summer. 11. I imagine he is very rich. 12. He imagines that he understands German, because he has been in Germany. • 13. Do not imagine that German is easy. 14. Sit down, please, and wait quietly. 15. We hurried, but we came too late. 16. The princess was sitting in the reception-room when the door opened and the prince entered. 17. They greeted each other very friendly, for they had not seen each other for a long time. 18. "I am glad to see you, especially as I have heard so much of (von) you," exclaimed he. 19. I imagine he is conceited, but he is not stupid. 20. Do not be in a hurry to get married. 


\section{LESSON XXXIX}

121. Impersonal Verbs. - An impersonal verb is a verb which can take only $\mathfrak{c}^{2}$ or an impersonal noun as its subject (compare in English: 'it behooves me'). Examples: es regnet, it rains; es idneit, it snous; bas llnglit(f gejd)ah, the misfortune happened. - Impersonal verbs are more common in German than in English.

(1) Besides verbs expressing a state of the weather, German has some impersonal verbs which in English are personal, as: es gelingt mir, I succeed; but (as in English) ber Berjud) ge= lingt, the experiment succeeds.

(2) The impersonal form is also used in many idiomatic phrases embodying a verb that is not always impersonal, as: Wie geht es Ghnen? How are you? ihr tut es leid, she is sorry; es friert midh, I am cold.

$a$. Abstract action can be expressed by making the verb impersonal, as: es flopft, there is a knock; es flingelt, some one is ringing.

122. Idiomatic uses of $\mathrm{e}^{3}$. - C i is used somewhat like the English 'there', at the beginning of a sentence, to bring the verb before the real subjeet. It is used, however, more frequently than the English 'there'. The verb agrees with the real subject (except in $\mathrm{es}$ gibt, there are):

Gs waren cinmal zwei Sïnige, there were once two kings.

(E⿱ $\mathfrak{3}$ fehlen mir zwei Büd)er, I lack two books.

(1) Unless $\mathfrak{c}$ introduces the sentence, it must not be used in the sense of 'there', excepting in es gibt, there is, there are; es gibt is followed by the logieal subject in the accusative case, the logieal subject becoming the object of the verb, thus:

Ginmal gab es ciucu fänig, once there was a king.

Şier gibt es fcinc Etiiffle, there are no chairs here. 
(2) Note the following phrases:

id) binl $\mathrm{es}$, it is $I$.

bu bijt $\mathfrak{e s}$, it is you.

$\mathfrak{c r}$ (jice, $\mathfrak{c} s)$ ijt $\mathfrak{c} s$, it is he (she, it).

bitt idy $\mathfrak{e s}$ ? is it $I$ ? wir find $\mathrm{cs}^{2}$, it is we.

fic jint $\mathfrak{c} s$, it is they.

Sic fitto $\mathfrak{e s ,}$ it is you.

find Sie es? is it you? etc.

\section{VOCABULARY}

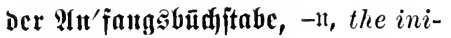

tial letter.

Dor Ladon,", the store, shop. dic Munmmer, -ll, the number. $\mathfrak{D a g}$ Tē(c) phone book.

Dos (Gswitter, -, the thunderstorm.

$\mathfrak{h a g e f t r}$, to hail.

Dontern, to thunder.

blificn, to lighten.

flingelit, to ring the bell.

$\mathfrak{e} \mathfrak{F}$ flingelt, the bell is ringing.

fehlen, to lack, to be wanting. $\mathfrak{w a} \mathfrak{B}$ fehlt $\mathfrak{J h}$ ten? what is the matter with you?

gelin'gen, gelang, ift gelungen (imp. dat.), to succeed.

c⿱⺈ gelingt mir, I succeed.

leib tun, to be sorry.

e: tut wix leid, I am sorry. [him. $\mathfrak{c}$ tut uir leid, I am sorry for c: freut mid, I am glad.

frieren, frōr, gefrōren, to freeze, be cold.

c: fricrt midf, I am cold.

wic geht $\mathfrak{c}$ S Jhuten? how are you? $\mathfrak{c} \mathfrak{g} \mathfrak{g e h t}$ ntir gut, I am well.

\section{READING EXERCISE}

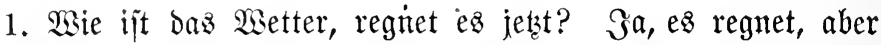

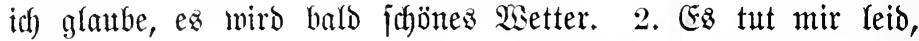

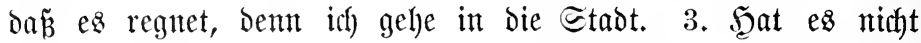
eben gedonnert? Sa, es donnert, es fommt ein Bemitter. 4. Yiun hagelt es, idh Denfe, heute gibt ez fein fünoz Wetter. 5. Es flingelt, gehen $\Xi_{i e}$, bitte, an bie Tiir, Marie! 6. Suten Mrorgen, berr Mener! SBie geht es Ghnen? Sanz gut, banfe.

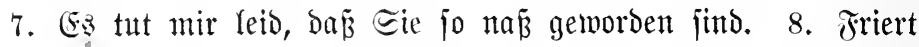
es ভie? Tein, fyer in bem Şauje ijt es warm genug. 9. Waarum haben Sie nidjt telephoniert? Es ijt mir nidjt gelungen, Shre 
Telephonnummer $z_{4}$ finden. 10. Es gibt jo viele Ramen unter

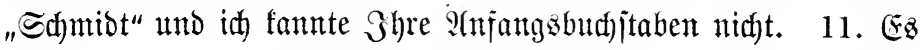
waren audh feine Drojdten auj ber Straje. 12. Wie geht ez Shrer Fraut Mutter, Seerr Mieyer? Danfe, ez geht ihr befjer. 13. (Ez freut mid), daz ju hören; ez hat mir jo leio getan, alz id) von ihrer Aranfheit hörte. 14. ந̆offentlid) wird es Dem $\mathfrak{A r}_{\mathfrak{z}}$ te

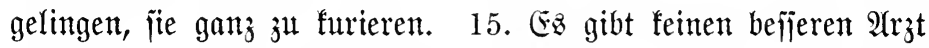
in ber Stabt, er hat fdon mandhen furiert. 16. Der arme Serr

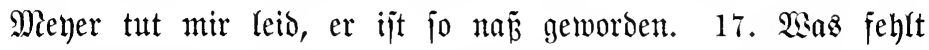

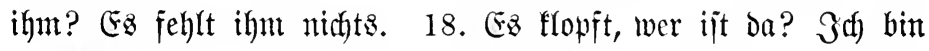
ez, Sarl. 19. Siun, was fehlt bir, Sarl? Miir fehlt (Seld. 20. Эa) benfe, bu hajt jwei Marf. 21. Эa, aber ez gelang

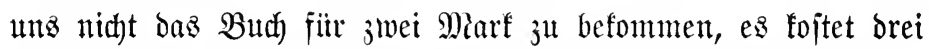
Mark. 22. Ez waren feine $\mathfrak{B}$ itd

\section{DRILL}

Give the German equivalent of: he succeeds; she succeeds; he has succeeded; we have succeeded; she will succeed; he is sorry; he is sorry for me; I am sorry for the woman; she is sorry for him; we are sorry for you; they are sorry for us; nothing is the matter with him; what is the matter with her (them, us, you)?

\section{WRITTEN EXERCISE}

1. It is thundering and lightning. I) not go out. 2. Now it is hailing. 3. I am sorry that it is hailing; the poor farmers will lose everything. 4. We are sory for the poor farmers. 5. Do you think to-morrow will be fine weather after this thunderstorm:" 6. There is a knok; please open the door. 7. How do you do, Mr. S., I am glad to see you. 8. I am very well, thank you, but my father is not well. 9. I am 
sorry to hear it. What is the matter with him? The doctor does not know. 10. Is there a good physician in this town? There are many physicians in our town, but not many good ones. 11. I am cold; please shut the door. 12. I have telephoned [to] him, and he says he is coming to-morrow. 13. Do you know his initials? No, but they are in the telephone-book. 14. Are there no cabs in this town? There are only three, but I have succeeded in getting one (to get one). 15 . He lacks money; he has only two marks and the book costs three. 16. There is in the town no good store for old books. 17. She has succeeded, because she has studied diligently. 18. What is the matter with you, are you ill? Nothing is the matter with me, but I am cold. 19. Please, ring the bell. 20. I believe some one is knocking; please go to (an) the door.

\section{LESSON XL}

\section{Passive Voice.}

The passive voice is formed by combining the verb merben (to become) with the past participle of transitive verbs.

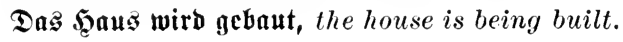

(1) Conjugation of fiflage $\mathfrak{n}$ in the Passive.

$$
\text { Present Past }
$$

idf werbe gejđ̆lāgen, I am being idf wurbe gejdjlagen, I was being beaten, I am beaten. ou wirjt gejulagen, etc. beaten, was beaten. ou wurbejt gejalagen, etc. (See Appendix for conjugation in full)

Perfect id) bin gejd)lagen worbon, I have been beaten. bu bijt gejallagen worben, etc.
Pluperfect idf war gejd,lagen worben, I had been beaten. bu warjit gejdjlagen worben, etc. 
Future

id) werbe gejdlagen werbeu, I shall be beaten.

bu wirjt gejulagen werben, etc.
Futcre Perfect id) werbe gejdlagell worben jein, I shall have been beaten. Du wirit gejdjlagent worbel jein.

IMPERATINE: werde gejdlagen, be beaten. werbet gejdilagen, be beaten. werben Sie gejalagen, be beaten.

INFinitive: gejdlagen werden, to be beaten. gejdlagen worben jeill, to have been beaten.

a. Notice worben, as past participle, instead of geworben; otherwise the conjugation is the same as weroen with an adjective, e.g.:

idf werbe alt, I am getting old.

id) werbe gejdflagen, I am (getting) being beaten.

(2) In English the auxiliary 'to be' is used to express passive action (he is being beaten, he is beaten), but also the result of completed action (the house is built). In German the passive action is expressed by merben; the result of completed action, or a condition, is expressed by jein, thus:

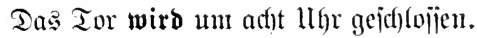

The gate is closed at eight o' clock.

('The closing is being done at eight o'clock.)

Das Tor ijt um ad)t llyr gejulojijen.

The gate is (already) closed at eight o'clock.

(The closing has taken place before eight.)

a. Hence werden retains in the passive voice its meaning of becoming, getting, and denotes an action going on at the time indicated by the tense of the verb.

(3) The agent of a passive action expressed in English by the preposition ' $b y$ ', is expressed in German by won.

Er wirb von feinem Bater geliebt, he is loved by his father.

124. In changing from the artive construction to the passive, the object of the active verb becomes the subject of the 
passive; while the subject of the active verb is put in the dative with von:

Der Ruabc fanlägt bcn Scund, the boy beats the dog, becomes, in the passive construction,

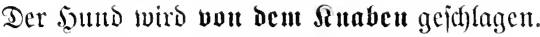

The dog is being beaten by the boy.

(1) If, however, the verb is intransitive, or takes the personal object in the dative, the verb becomes impersonal in the passive:

(Es wurbe mir von ihm geraten, I was advised by him.

Jhm wurbe geholfen, he was helped.

Mir wirb gejagt, I am told.

Gis wurbe getangt unb gejungen, there was dancing and singing.

125. The indefinite pronoun man (one, they, people) is commonly used with the verb in the active voice, instead of a passive construction, when no agent is expressed:

Mian baut viele şäujer in ber Etadt.

Many houses are being built in the city.

Mau jagt, it is said.

Man tanjte uno jang; man half ifm; man jagte mir.

126. In some idioms the reflexive is used to express a passive:

Das veritcht jidf), that is understood.

Das (Geld hat fid gefundel, the money has been found.

127. An active infinitive following the verbs jein and lajjen has often passive meaning, as:

Dả ijt $\mathfrak{z}^{\mathfrak{H}} \mathfrak{h} \mathbf{v}$ fith, that is to be hoped.

Die P(rbeit ijt nod) $\mathfrak{n}$ mad $\mathfrak{n}$, the work is still to be done.

Das Syan ijt $\mathfrak{d t}$ vermicten, the house is to rent.

Dả läjt jịd) utcht jagen, that cannot be told. 


\section{VOCABULARY}

bie $\mathfrak{u h r}$, -ent, the clock, watch.

bic $\mathfrak{A} \mathfrak{A}$ ittcllung, -cti, the exhibition. bic Rebc, $-n$, the speech.

$\mathfrak{D a} \mathfrak{a} \mathfrak{T} \overline{\mathfrak{D}},-\mathfrak{e}$, the gate.

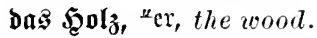

bas $\mathfrak{5} \mathfrak{o t c l} \mathfrak{l}^{\prime},-5$, the hotel.

bas Flcijd, the meat. [refuse. $\mathfrak{a b} \mathfrak{b}^{\prime}$ weijeu, wies ab, abgewiejen, to $\mathfrak{u m}^{\prime} \mathfrak{h a u e n}$, bieb um, umgelyanen, to cut down.

$\mathfrak{a n t}^{\prime}$ itrcidjent, ftrid) an, angcitriçent, to paint.

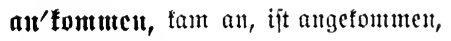
to arrive. $\mathfrak{a n}$ 'fangen, fing ant, angefanten, (fängt ant), to begin, commence. $\mathfrak{a b}^{\prime}$ iterben, jtarb ab, ijt abgejtorben, (of plants), to die, fade.

unt wic vide $\mathfrak{l t h r}$, at what time. hoffen, to hope.

raudfen, to smoke.

cröfï'ncre open.

veruteten, to rent. tanjzen, to dance. $\overline{\mathbf{c}} \mathbf{i} \mathrm{t}, \mathrm{adv}$., only; arlj., first. fer'tig, ready, finished. utci'jtens, mostly. $\mathfrak{g r i \overline { i } u}$, green.

\section{READING EXERCISE}

1. Diejes Şaus miro von meinem Snfel gebaut. 2. Ģ warbe johon letstez Gahr angejangen, aber erjt diejez Gahr wirb ez fertig werden. 3. Taz ந̧aus meines Baters ijt aud bon meinem Snfel gebaut, er hat die meijten groj̈en Şäujer in ber

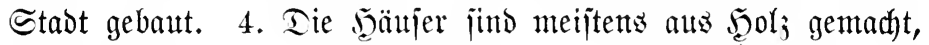
benn $\mathfrak{S}$ olj ijt bei unts jienlich billig. 5. Die Bäume vor bem Geauje jind alle von meinem Bater vor vielen Gabren gepflanjt worben, fie jutto alle fehr groj gemorden. 6. Cin Baum ijt umgelyaten worden, weil er abgejtorben war. 7. Ilnjer Şats mird jetzt grïn angeitridsen, frïher war es meij. 8. llm wie viel

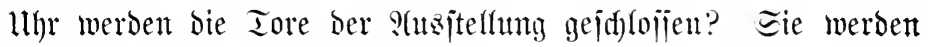
un zelnn llyr abenoz gejulojien und um adjt llhr morgens

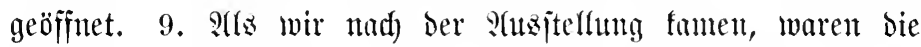
Tore nod) nicht geöfinet, ez war aber erjt fieben llyr. 10. E\& wurbe unz geraten frïh hinjugehen, weil ez jpäter jo voll wirb. 


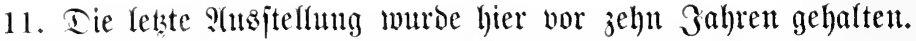

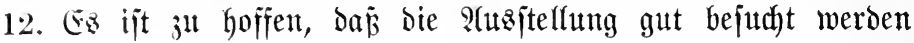
wiro. 13. Gn ber Thsitellung wirb nicht geraudht. 14. Ilnjere Shajtellung wurbe von dem Fräjionenten eröfïnet; viele Reden murben gehalten. 15. Sn unjerer Stadt gibt ez jefr viele Deutjahe, und es wirb viel Deutich gejprodhen. 16. Man hört mehr Deutja

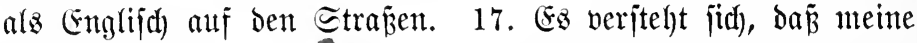
Britier Deutich fpredsen, Denn ju şauje wiro immer Deutid) geiproden. 18. 3n bem Seotel, wo wir fint, wiro abends immer getanzt. 19. Eind nod) Zimmer ba ju vermieten? Ein Zim= mer ijt nod) ju haben, wenn es nidgt idjon heute morgen ver= mietet worsen ijt. 20. Man jagt, alle bootels jind boll, es ijt fein 3immer mehr ju befommen, viele Seute jint abgemiejen morben.

\section{DRILL}

A. Change the active construction to the passive in the fol-

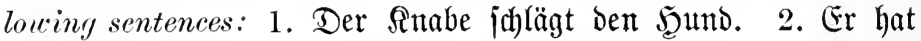

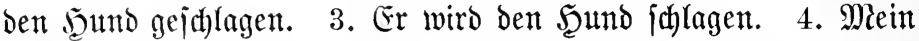
Bater baut ein Sauss. 5. Er hat bas Şauz gebaut. 6. Er wiro ein Sauz bauten. 7. Die Mutter fahreibt einen Brief. 8. (Sejtern farieb bie Mutter einen Brief. 9. Sie hat ben Brief idhon geidrieben. 10. Morgen wirb jie einen Brief

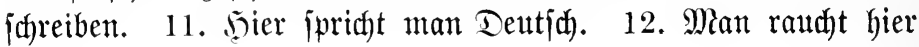
nidft.

B. Change the passire construction to the active: 1. Die Tïr wurbe von ilum geöffnet. 2. Die Tïr ijt von ihm geöffnet worben. 3. Der Solyn wirb non jeinem $\mathfrak{B}$ ater geliebt. 4. Der Edjüler wirb von jeittem Sebrer gelobt werben. 5. Die Edjitler werben von bem sehrer gelobt. 6. Die Taffe ift won ihr jer= brodhen worden. 7. Şier wird nidht gejprodhen. 8. Es murde gejungen und getanzt. 


\section{WRITTEN EXERCISE}

1. Very large houses are being built in our street. 2. The biggest house has been built by Mr. S. 3. Trees will be planted, and in a few years the street will become very pretty. 4. The old trees are being cut down and young ones planted. 5. The houses are being painted brown; they were formerly green. 6. The $\operatorname{dog}$ is being beaten by his master, because he has stolen the meat. 7 . The gates are opened every morning at eight o'clock. 8. The gates were open when we arrived. 9. The gates of the exhibition are closed every evening at ten o'clock. 10. The exhibition is held in this town. 11. This book is very much read by the students. 12. I was advised not to read the book. 13 . The book is much praised, but little read. 14. He was told that the gates are closed at eight o'clock. 15. Has the book been found? Yes, it was found by $m$ brother under the table. 16 . Here are rooms to rent. 17. German is spoken here. 18. We were advised to learn German. 19. The poor man is being helped by his rich friends. 20. He was loved by all his friends. 21. They say all the houses in this street are rented. 22. This house was rented by my father to (an, acc.) an old friend. 23. The work is being done by two men. 24. The work has been done. 25. The work will be done. 26. The work had been done when we came.

\section{LESSON XLT}

\section{THE SUBJUNCTIVE MOOD}

128. The Present Tense. - The present tense of the subjunctive mood of any verb, whether strong, weak, or irregular, is formed by dropping the $\mathfrak{n}$ of the infinitive, for the first and third persons singular, and adding the personal endings for the other persons: 
Present Tense

$\mathfrak{h a b e u}$

iif) bābe

Dul babejt

er babe

wir haben

if) lobet

jie habent werbel

mërbe

werbejt

meride

jeicut

jeict

jeicn

jei

jeicjt

ici

The present than the present indicative.

Note. - The irregular verb tun (to do) adds e: idf tue, bu tue it, er tue.

\section{9.}

id $\mathfrak{h a b e}$ gehabt

Du $\mathfrak{h a b c j t} \mathfrak{g e h a b t}$

$\mathfrak{e r} \mathfrak{h a b e}$ gehanbt

etc.

idf habe gefauft bu liabejt getaujt

er habe gefauft etc.

\section{0.}

idf werbe habelt bu werbejt haben er werbe habet

Perfect Tense

idf jei gewejen

Du jeicjt gewejent

er jei gewejen

etc.

idf habe gelejen Du habejt gelejen er habe gelejen etc. idf jei geworden Du jeicit geworben er jei gewordeu etc. (id) habe gewufist

ou habejt gewujk t

cr habe gewu ząt

etc.

Future Texse

$\begin{array}{llll}\text { jein } & \text { werben } & \mathfrak{f a u j e n} & \text { wifjen } \\ \text { jein } & \text { werben } & \mathfrak{f a u f e n} & \text { wij̄en } \\ \text { jein } & \text { werben } & \mathfrak{f a u f e n} & \text { wifjen }\end{array}$
etc.

131. Uses of the Subjunctive.

(1) Whereas the indicative mood expresses facts, the subjunctive expresses something which the speaker does not state as a fact, but as a possibility, condition, hope, wish, belief, or as the statement of another person. 
(2) Definite rules that the subjunctive must be used after certain verbs cannot be given; the use of the subjunctive is more a matter of feeling than of definite rules.

(3) After verbs of hoping, thinking, believing, fearing, in the present tense the indicative is generally used, as we make that which is hoped, thought, believed or feared a fact; but, if the introductory verb is in a tense of past time, a subjunctive follows, especially if we wish to imply that what we hoped, thought etc., was not true:

J(t) glaube, baj er ba ijt.

I believe that he is there.

Jah habe geglaubt, baj $\mathfrak{\mathfrak { z }}$ er ba jei.

I believed that he was there.

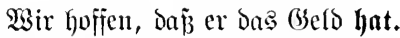

We hope that he has the money.

Wir haben gehoffit, da

We have hoped that he had the money.

Jff fïrd)te, baj jie nidft fommen wirb.

I fear that she will not come.

Ja) habe gejür(f)tet, bã jie nidgt fonmen werbe.

I feared that she would not come.

132. Subjunctive of Indirect Discourse. - Indirect speech stands, as a rule, in the subjunctive; not implying thereby that the statement is not a fact, but nerely that the speaker is quoting the words of another:

Bater jagt, er jei frant.

Father says he is ill.

Mutter hat mir gejagt, jie jei heute ben ganjen Tag zu sauje.

Mother told me she would be at home all day.

Err jagt, er wijie nicht, ob jein Bater ju joanje jei.

He says he does not know, whether his father is at home.

Bater fragte midh, ob if) in ber Silule gemejen jei.

Father asked me if I had been at school. 
a. If, howerer, the speaker gives the indireet speech more as a fact than as the statement of another, the indicative may be used:

Der Lebrer fagt, idg bin Flcipig, the teacher says I am diligent. The same speaker would probably say:

Der Lehrer jagt, idf jei jaul, the teacher says I am lazy.

Thus the German subjunctive can express shades of meaning impossible in English.

\section{VOCABULARY}

ben $\mathfrak{T a} \mathfrak{a} \mathfrak{b a r a u} \tilde{f}^{\prime}$, the next day. bejdjäf'tigt, busy.

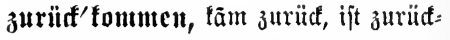
getömmen, to come back.

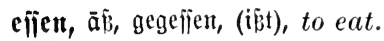

\section{READING EXERCISE}

1. (5r jagte mir, jein Bater jei franf. 2. Sd) fragte ihn, ob

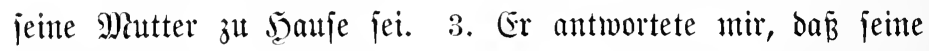
Matter morgen ju Şauje jein werde. 4. Jdh habe immer ge= glaubt, daż Sie in Deutifhland gemejen jeien, weil Sie fo gut Deutid) iprechen. 5. Эal) glaube, er ijt in Deutid)(and gemejen. 6. Er hat inmer gehofft, baj jie zuriiffommen werde, aber fie ijt nicht juriidfgefommen. 7. Er hofft, Daß jie zurïfftommen wirb.

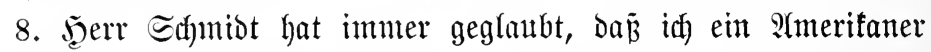
jei, aber idi) bin ein Deuticher. 9. Der Echitter jagte mir, ba $\mathfrak{B}$

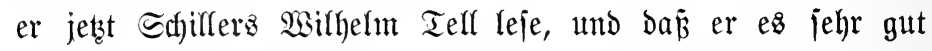
veritehe. 10. Эah hoffe, er veriteht es, Denn er hat immer fleisig gelernt. 11. Der Segrer hofft, baß̄ bie Edjiiler allez veritehen,

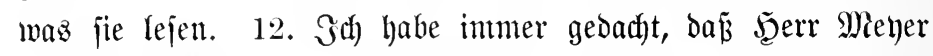
ein reid)er Mann jei, aber id) höre, baj er jehr arm ijt. 13. Ja hatte friiger geljört, oaj er fehr reid jei. 14. Wir wifjen nidht, ob er fommen wird ober nicht. 15. Wir mußsten nidjt, ob er fommen werde. 16. Shl weī́, Dá̧ er morgen fommt. 17. Der Sehrer fagte Dem $I n a b e n, ~ D a \tilde{B}$ er faul jei. 18. Der $\mathfrak{i n a b e}$ jagte 


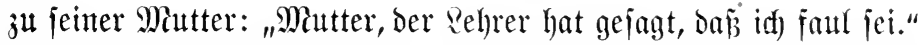

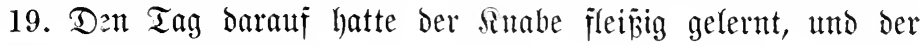

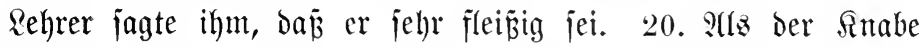
nad) Sauje fam, jagte er ju jeiner Mintter: "9lutter, Der Sehrer

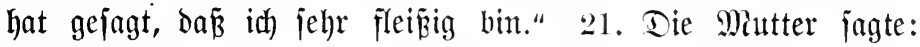

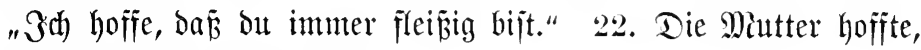

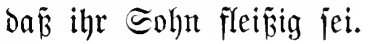

\section{DRILL}

A. Conjugate in the present, perfect and future tense of the subjunctire mood: ipred)en, eljen, fommen, reijen, faldren, fallen.

B. Change the following direct discourse to indirect, using the conjunction $\boldsymbol{b a} \tilde{\mathfrak{B}}$ after jagte, and ob after fragte:

1. Die Sehrerin jagte: "Ŷtnna, bu bij̄t ein fleiz̄iges Miäbd)en."

2. Mein Bater jagte: "Эd) habe das Budf gefauft."

3. Er jragte: "Wुat Der Mann Sinder?"

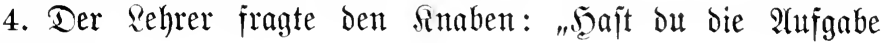
gemadft?"

5. Sie fragte: "Siauft Deinte Matter bie Bürher?"

6. Mein Bruder jagte: "G(h) werbe morgen fommen."

C. Change the following indirect discon'se to direct:

1. Er jagte mir, er erintmere jith meinter.

2. Die Dame jagte, da $\mathfrak{\beta}$ jie jich freue, den herrn ; jehen.

3. Ter jeer antmortete, daj ez iłm leio tue, es ju hören.

4. Der Sehrer fragte Den Edjuiler, ob er das Buth habe.

5. Daz Miäuden jagte mir, bas sietter jei joün.

f. Sie jagte, bas Wetter jei jehr fult gewejen.

\section{WRITTEN EXERCISE}

1. She tells him that her mother is not at home. 2. He is asking whether my father is in New York. 3. I do not know 
whether he will buy the book or not, but I hope he will buy it, for I gave him the money. 4. My teacher has always believed that I have been in Germany, because my exercises are so good. 5. I told him to-day that I have never been in Germany. 6. He says that he has the book at home and that he will bring it to-morrow. 7. I hope he will bring it. 8. She says that she is reading the book. 9. She says that she has read the book. 10. I hope that you have been well. 11. The boy says that his father has not been ill. 12. I do not know whether he remembers me. 13. He says that he remembers me as [a] boy. 14. The teacher says that the exercise is very easy. 15. We all hope that it is easy. 16. His sister does not believe that her brother has read the book. 17. He says he has read it, but has not understood it. 18. The poor man says that his wife is ill and that he has no money. 19. This poor woman tells me that her husband has been very ill. 20. He asked me to tell you that he has been very busy. 21. The little boy says he is buying the book for his mother. 22. She says she does not know whether it is true. 23. He says he knows it. 24. I do not believe that he knows it.

\section{LESSON XLII}

\section{THE SUBJUNCTIVE MOOD (Continued)}

133. The Past Tense. - In all the regular weak verbs the past subjunctive has the same forms as the past indicative.

In strong and irregular verbs the past subjunctive is formed from the past indicative by modifying the root-vowel (giving it the umlaut) in all persons and adding $\mathfrak{c}$ for the first and third persons singular: 
Past Texse

\begin{tabular}{|c|c|c|c|}
\hline $\mathfrak{h} \mathfrak{a} \mathfrak{b} \mathfrak{e} \mathfrak{t}$ & jeill & werbelt & Iejeı \\
\hline ich) bätte & wäre & twïrbe & Yäje \\
\hline du hätteft & twärejt & wütrbejt & läjejt \\
\hline ex hätte & wäre & twïrbe & läje \\
\hline ir hätteıt & เwärett & wütroen & läjent \\
\hline $\mathfrak{x}$ hättet & wäret & wïrdet & läjet \\
\hline jie Gätten & เwärent & mö̈roent & läjêt \\
\hline
\end{tabular}

Notice that these endings, excepting in the case of jeitt, are the same as those of the present subjunctive.

134. Pluperfect Tense

iđj hätte gehabt, gelejen, gefauft. iđj wäre gewejeı, geworben. bu hättejt gehabt, gelejen, gefauft. bu wärejt gewejen, geworben. er hätte gehabt, gelejelt, gefaujt. er wäre gewejen, geworben. etc.

etc.

\section{5.}

Future Perfect

id) werbe gehabt haben.

bu werbejt gehabt haben.

er werbe gehabt haben. etc. id werbe gewejen jeilt. bu werbejt gewejen jein. er werbe gewejen jeit. ete.

136. In indirect speech or questions, and after verbs of thinking, hoping, etc., in the past tenses, the present and past subjunctive are both used for time present or future with reference to the main verb; the perfect and pluperfect for time previous to the main verb, preference being given to the tense which has the more distinctive subjunctive form:

Bater jagte, er jei tranf unb fomme heute nicht.

or, Bater fagte, er wäre franf mo fäme heute uicht.

Father said he was ill and was not coming to-day.

Er jagte, er habe das (beld nicht gefabt.

IIe said he had not had the money.

Er jagte, jic hätten Das (befo nid)t gebabt.

IIe said they had not had the money. 
Jdh hofite, er jei hier or wäre hier, I hoped he was here. Er fürthtete, fie jei frant gewejen, or wäre frant gemejen. He feared she had been ill.

137. The Imperative Subjunctive. - The Imperative Subjunctive ('hortatory') denotes a command and is usually translated by 'let'. As the imperative mood has only the second person, the imperative subjunctive is used to express a command in the first and third persons:

Eeicu wir rufig, let us be quiet.

(Gehen wir tadd) bauje, let us go home.

Edrreibe er ben Brief, let him write the letter.

138. The Optative Subjunctive denotes a wish, and is often translated by 'may', the present tense, referring to a wish for the future, or to one that may be realized in the present; the past tense to an unrealized wish for the present; and the pluperfect to a wish unrealized in the past:

(bstt behiite bid)! May God protect you!

(E⿱ Is Iebe ber Siaifer! Long live the Emperor!

Seätte iif) uur (b̌elb! Had I only money!

Wäre Bater nut hier! If father were but here!

Şätte idf) Das nur gewuípt! IIad I only known that!

139. The Potential Subjunctive expresses possibility. It is usually translated by 'may', 'might', 'could', 'would':

Sie bem andf jei, however that may be.

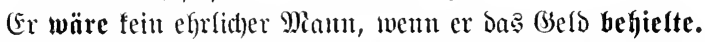

He would not be an honest man, if he kept the money.

Sie hätte Beit genutg, wenn fie ę tun woulte.

She would have time enough, if she wanted to do it.

140. The Unreal Subjunctive expresses something contrary to fact, i.e., a condition of things that does not agree with the facts: 


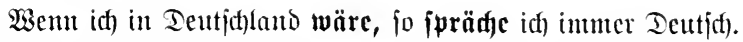

If I were in Germany (but I am not in Germany), I should always speak German (but I don't always speak it now).

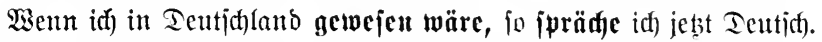

If I had been in Germany (but I have not been there), I should now speak German (but I do not speak it).

Wenn er bas beld hätte, fo gäbe er es ihr.

If he had the money (but he has not got it), he would give it to her (but he does not give her any).

Wenn er bas (belo gehabt hätte, fo hätte er es ígr gegeben. If he had had the money, he would have given it to her.

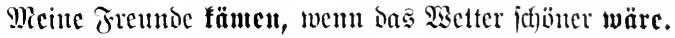

My friends would come if the weather were finer.

$a$. Notice that in both main and dependent clauses the verb stands in the subjunctive; the past subjunctive for present time; and the pluperfect subjunctive for past time.

$b$. If the clause expressing the condition stands first, the verb of the main clause is generally introduced by $\mathfrak{j}$.

(1) Just as sometimes in the case of ' if' in English, menn may be omitted and the verb placed at the beginning:

Seätte idh Das (beld gebabt, fo hätte idh es bir gegeben.

Ilad I had the money, I should have given it to you.

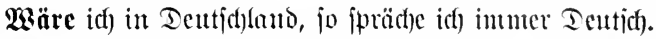

Were I in Germany, I should always talk German.

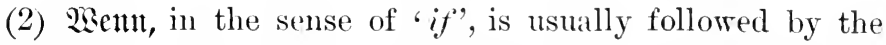
subjunctive if the verb is in a past tense; if the verb is in the present tense, the indicative is used:

Menn er hicr ijt, if he is here (he may be here).

$\mathfrak{W e n n} \mathfrak{e r}$ hier wärc, if he were here (but he is not here).

Saem er Das (belo hat, if he hus the money (he may have it).

Wenn er Das (belo bätte, if he had the money (but he has not).

But: $\mathfrak{B e n n}$ er bas gejagt hat, if he (actually) said that. 


\section{VOCABULARY}

crmar'teit, to expect.

$\mathfrak{a} \mathfrak{z}^{\prime} \mathfrak{g e b e n}, \mathfrak{g} \mathfrak{a} \mathfrak{b}$ aus, ausgegeben, (gibt atts), to spend.

fürd)ten, to fear.

Iaut rufen, rief, gerufen, to shout. crfen'uten, erfannte, erfannt, to recognize.

zuērit', first, at first. zufrie'ben, satisfied. fovicl', so much.一 ăd), oh, ah.

\section{READING EXERCISE}

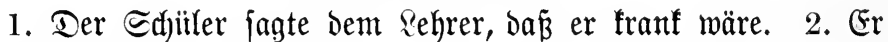

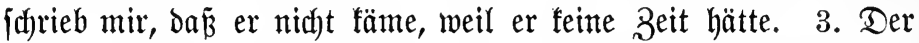

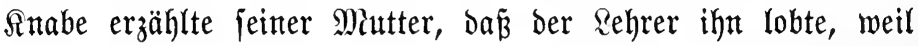
er fo fleiß̄ig gemorben wäre. 4. Machen wir zuerjt unjere Arbeit, und dann gehen wir in ben Starten! 5. Seien wir zufrieden mit dem, was wir haben! 6. SUlz ber Saifer tam, riefen wir alle: „Ez lebe Der Saijer!“ 7. "2l(h), hätte idh nur Belo!" jagte die arme Frau. 8. "Wäre Matter nur zu Scauje!“ riefen bie fleinen ßinder. 9. Wenn ich fleip̈iger gelernt hätte,

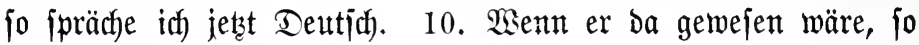
hätte idh ihn gejehen. 11. Şätte idh bas (beld gehabt, fo hätte idh Daz $\mathfrak{B u d}$ gefauft. 12. Şätte jie mid) gejehen, fo hätte jie mich erfannt. 13. Wenn wir Deutjd) gejprochen hätten, jo hätte er unz verjtanden, denn er ijt ein Deutjher. 14. Эah wäre auth trant geworben, wenn ich fo viel gegefien hätte. 15. Wenn Sie frither gefommen wären, fo hätten Sie ihn gejehen, denn er ging eben fort. 16. Da mein Bruber unz nicht fachieb, fo

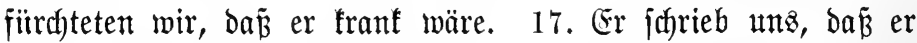
lange franf gemejen wäre, aber $D a \tilde{\beta}$ ez ihm jetzt befjer ginge. 18. Wienn er fommt, fo jagen Eie ihm, bitte, bá wir ihn

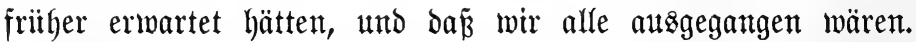
19. Err jagte mir, er fäme morgen, went bas Wetter fujön wäre. 
20. "Wenn baz $\mathfrak{B}$ etter j(j)ön ijt, fo fomme idh, aber wenn es regnet, jo bleibe id) ju Şaule," jagte mein Freunt.

\section{DRILL}

A. Give the subjunctive for the follouing indicative forms: jie ijt; er hat; idf wurbe; er jurieb; jie jureibt; er jieht; jie liejt; er jah; er las ; wir famen; er hat gehabt; er wirb jein; idh hatte gelobt; idf) lobte; er lobt; er jtirbt; er jtarb; er ijt gejtor= ben; fie nimmt, jie nahm.

B. Give the indicative for the following suljunctive forms: er wäre; jie hätte; wir jeien; er verlöre; jie jalle; er jidlafe; id ipielte; id hätte geipielt; er wiinte, jie wijje.

C. Change the indirect speech in the Reading Exercise into direct speech.

$D$. In the Reading Exercise of Lesson XLI, ehange (whenever possible) the present subjunctive to pust subjunctive.

\section{WRITTEN EXERCISE}

1. The little girl told her teacher that she had been ill. 2. He told me that he had the book. 3. She said that her mother was not at home. 4. He wrote that he was coming to-morrow. 5. Let us run home; it is late. 6. Let us talk German, and then we shall learn it. 7 . "If father were only at home!" cried the poor children. 8: "If mother only knew it!" said the little boy. 9. If I had the books, I would read them. 10. The man would have money enough, if he worked. 11. If he did not spend so much money, he would be a rich man. 12. If the boy had studied more diligently, he would know more German. 13. I should have recognized him, had I seen him. 14. He would not hive become ill, had he stayed at home. 15. She would have seen me, if I had come earlier. 16. If we had seen the enperor, we should have shouted: 
"Long live the emperor!" 17 . If he had the money, he would give it to his old mother. 18. If he has money, he spends it. 19. Had I the money, I should be happy. 20. My mother feared that father was ill, but he wrote her that he was quite well. 21. I hope he is here. 22. I do not know whether he is here. 23. She did not know that he was here. 24. I thought that you were at home.

\section{LESSON XLIII \\ REVIEW (LESSONS XXXVI-XLII)}

141. 1. Do separable verb-prefixes separate from the verb in dependent clauses? Illustrate the rule in a sentence.

2. What parts of speech can Der, bic, bas be, besides being definite articles? Illustrate by short sentences.

3. Where does the verb stand after a relative pronoun? Where, after a demonstrative pronoun?

4. Conjugate tum and wifien in the present indicative.

5. When should one translate 'know' by wifien? When by fement? Illustrate in sentences.

142. 1. How is the present participle of all verbs formed? Is the present participle used in German as frequently as in English? As what part of speech is it chiefly used in German?

2. Wherein do verbs ending in ieren differ in conjugation from other weak verbs?

3. Where does the verb stand after verbs of saying and thinking, if $\mathfrak{d a} \mathfrak{\beta}$ is omitted? Illustrate by example.

143. 1. Give the genitives of the personal pronouns. Form a sentence illustrating their use.

2. In what eases may fird be? For which English words may it stand ?

3. Are reflexive verbs used more in German than in English ?

4. Give a reflexive verb with the reflexive pronoun in the dative, and two with the reflexive in the accusative.

5. What anxiliary do all reflexive verbs take?

6. When does a transitive verb become reflexive? Illustrate by example.

7. Mention a reflexive verb that governs the genitive. 
144. 1. What is an impersonal verb? Illustrate by examples.

2. Give the German for: it is she; it is they; there are no books here; there once lived a king.

145. 1. With what anxiliary is the passive voice formed? Illustrate by example.

2. What meanings may werden have in English? Illustrate each meaning.

3. How should one express the English 'by' with a rerb in the passive voice? Illustrate by example.

4. What is the difference in meaning between the two following sentences:

$$
\text { Das } \mathfrak{s a u s} \text { war gebant, als wir ba warelt. }
$$

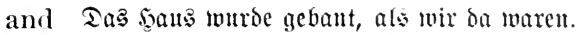

5. Is the passive used as much in German as in English? What substitutes can be used in German? Illustrate by examples.

146. 1. Give the rules for forming the present and past subjunctives (1) of weak verbs (2) of strong and irregular verbs. Give examples of each tense.

2. What, in a general way, does the subjunctive express, and wherein does it differ from the indicative?

3. Give an example of a subjunctive of indirect discourse, of an imperative subjunctive, of an optative, of a potential, and of an unreal subjunctive.

4. Is went (if) always followed by a subjunctive? Illustrate by examples.

\section{Leje it î ife.}

\section{Das Bäd̆lein.*}

Du Bädhlein, fillberbell uno flar,

Du eiljt voriïber inmerbar,

'Am llfer jtel' idf), jimn' uno jiun':

4

Sao fommit bu her? Sa gehjt bu hin?

Jaf) formm' aus ounfler jeljen $\Xi(d) o \dot{B}$,

Miein Sauf geht ïber Blum' und Mloos;

Ifuf meinem Epiegel jofwebt jo millo

Des blauen Simmels preundlid) Bildo. 
D'rum $\mathfrak{h a b}$ idf) frohen Sinterfinn;

Es treibt midh fort, weiß̄ nid)t wol)in,

Der midh) gerufen auz bem Etein,

12

Der, benf' idh, wird mein Fithrer fein.

Boethe.

${ }^{*}$ brooklet, ${ }^{1}$ silvery bright. - clear. ${ }^{2}$ past. - continually. ${ }^{3}$ bank. - I think. ${ }^{5}$ lap of the rocks, ${ }^{6}$ course. - moss. ${ }^{7}$ mirror. - floats, - mildly, kindly. ${ }^{8}$ heaven, sky. - poetic for freundliches. ${ }^{9}$ therefore. - cheerful. - child's mind. ${ }^{10}$.drives, urges. ${ }^{12}$ guide.

\section{2. $\mathcal{D}$ ergizmeinnicht.*}

Ez bliiht ein jăönez $\mathfrak{B}$ lïmdhen

$\mathfrak{A} \mathfrak{u} \mathfrak{f}$ unfrer grïnen $\mathfrak{2} \mathfrak{u}$;

Sein 'turg' ijt wie ber Şimmel,

4 So heiter und fo blaut.

Es weiz nicht viel jut reden,

Ultto alles waz es ipridft,

Sit immer nur basjelbe,

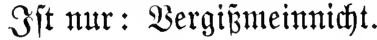

5̧offmann von Falferşleben.

* forget-me-not. ${ }^{2}$ meadow. ${ }^{4}$ cheerful. ${ }^{5}$ say, talk.

\section{Die Jahre verliert man nicht.}

Ein Şerr fragte einen fehr alten Mann, wie alt er fei. Der arlte fagte, er wijije nidht, ob er achtjig ober neunzig ${ }^{2}$ Gahre alt jei, aber hundert ${ }^{3}$ fei er nod nid t. $^{4}$ Der Seerr meinte, ez jei bod) jonderbar, ${ }^{6}$ da $\tilde{\beta}$ er baz nicht wifje. Er jragte ihn bann, ob er nidht wifie, wann er geboren ${ }^{7}$ fei, und ob er feine Gahre nicht zähle. T(ber ber alte Mann antwortete, er zähle jein (jeld, Denn das verliere er leidft, aber feine Gahre zähle er nicht, benn bie verliere er niemals.

${ }^{1}$ eighty. ${ }^{2}$ ninety. ${ }^{3}$ hundred. ${ }^{4}$ not yet. ${ }^{5}$ thought, said. ${ }^{6}$ strange. ${ }^{7}$ born. 


\section{Wor fprach die Wahrheit?}

Fin Bauter ging eines Tagez ju jeinem Yaabjar und jragte $\mathfrak{i h n}$ ob er ihm nidht jeinen Ejel ${ }^{1}$ auf ein paar Etunden ${ }^{2}$ leihen $^{8}$ tönnte, ${ }^{4}$ Denn jein Ejel märe trant und fönnte nidyt arbeiten. Der Siadbar jagte, er täte es gern, aber leiber ${ }^{5}$ hätte er jeinen Ejel idhon verliel)en, ${ }^{6}$ und er füme vor ?abend nidyt wieber. Der Bauer jagte, baz täte ihm leio, uno mollte ehen weggehen, alz ber Cjel im Etalle laut ju jahreien ${ }^{8}$ anfing. Ser Yiadhbar hatte nämlidh ${ }^{9}$ Den Ejel im Etalle und hatte ihn mur nicht leihen - mollen. ${ }^{10}$ Da jagte der Bauter, ber Efjel wäre ja im Etalle, und fragte aud ben 2 aadjbar, warum er jo gelogen hätte. "Jdh hätte gelogen?" rief ber Yiad)bar beleibigt, ", "aljo glauben Eie lieber meinem Ejel als mir?"

${ }^{1}$ donkey. ${ }^{2}$ for a few hours. ${ }^{3}$ lend. ${ }^{4}$ could. ${ }^{5}$ unfortunately. ${ }^{6}$ lent (out). ${ }^{7}$ was just going away. ${ }^{8}$ bray (scream). ${ }^{9}$ in point of fact. ${ }^{10}$ wanted. ${ }^{11}$ insulted.

\section{DRILL}

A. Change in 3 and 4 the indirect discourse to direct.

B. Substitute in 3 the past subjunctire for the present subjunctive.

C. Substitute in 4 the present subjunctire for the past subjunctive.

Questions. - 1. Wontady fragte ber serr ben alten Miam? 2. Sumute Der alte Mam ifm jein Sllter jagen? 3. Sie alt, meinte ber alte Mian,

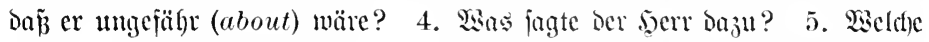

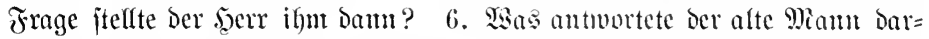
auf? 7. Sarmm jäflte ber alte Miann fein (belo und nidft feime Jahre? 8. (Erzä̆flen Eie bie ganje (bej(d)id)te!

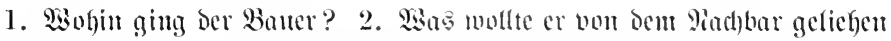

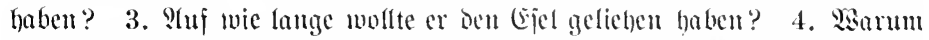

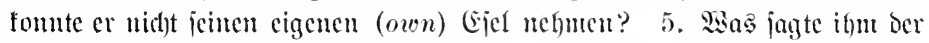

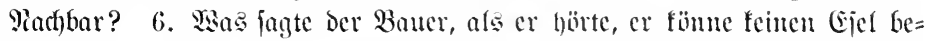
fommen? 万. צav war ber Ejel wirflid)? 8. Wis merfte (noticed) ber 
Baıter, Dá̃ Der Ejel im Stalle wäre? 9. Marum hatte Der Madjbar Dem Bauer vorgelogen, dajj fein Ejel nicht da wäre? 10. Wag jagte Der Bauer, als er Den Ejel jafreien hörte? 11. Wie lautete bie Antwort Des Machbars? 12. Erzählen Sie jelber bieje (Sejdid)te!

\section{LESSON XLIV}

147. The Modal Auxiliaries. The modal auxiliaries are: bürfen, bŭrfte, gebŭrft, to be allowed to, may (permission). fünnen, fŏnute, gefŏınt, can, to be able to. mögen, mŏ(t)te, gemŏ(h)t, to like (to), care to, may (probability).

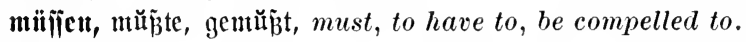
jŏllen, jŏllte, gejŏllt, to be, be said to; shall, ought to (in past tense). wŏllen, wŏllte, gemŏut, will, to want to, intend to.

148. Dürfen

föutuen

mögen

\section{Present Indicative}

I am allowed, may.

id) bărí

bu bărị̄t

cr barf

wir bïrien

ifgr büritt

jie biirien
I can.

id) fănn

๖u fănnjt

cr făıı

wir föunen

if) fömut

fie fönnen
I like, care to.

iđi) $\mathfrak{m a ̄ g}$

ou māgit

cr $\mathfrak{m a x} \mathfrak{g}$

wir mögen

ihr mögt

fic mögen
149.

I am allowed, may.

id bürfe
bu bürfejt
er bürfe
etc.

Present Subjunctive

I can.

id) tönue

Du fönne

er fönne

etc.
I like, care to.

$$
\begin{aligned}
& \text { id möge } \\
& \text { ou mögejt } \\
& \text { er möge } \\
& \text { etc. }
\end{aligned}
$$

150.

I was allowed, might.

id) Durfte
Past Indicative

I could.

id) tonnte
I liked to.

id mod)te 


\section{Past Subucactive}

\begin{tabular}{|c|c|c|}
\hline I might. & I could. & I should like to \\
\hline idf bïrite & id) fämute & id) Mädtc \\
\hline Ditrfitcjt & ১u fönutcjt & ১u mïd)tcjt \\
\hline $\begin{array}{l}\text { er bürfte } \\
\text { etc. }\end{array}$ & $\begin{array}{l}\text { er fönnte } \\
\text { ete. }\end{array}$ & $\begin{array}{l}\mathfrak{c r} \text { mädftc } \\
\text { ete. }\end{array}$ \\
\hline
\end{tabular}

a. Notice that the umlaut of the infinitive is dropper in the past indicative and the past participle, but used in the past subjunctive.

$b$. In the present indicative, the first and third persons singular have no personal endings (compare in English: I can, he can, I may, he may).

$c$. The present subjunctive is formed (as in all verbs) from the infinitive and shows no irregularity.

151. The German modal anxiliaries are inflected in all their tenses; whereas, in English, many tenses are lacking and must be supplied by other words, e.g.:

id) habe gefonnt, I have been able to. id habe gemuit, I have had to. id) $\mathfrak{m u}$ įte, I had to. id) foll, $I$ am to.

inf jollte, I ought to, ete.

Hence special care must be used in choosing the right modal auxiliary when translating from English into German.

In general it is well to bear in mind that:

biirfen usually conveys the idea of permission.

fönnen, ability or (in the subjunctive) of possibility.

mögen, liking, but also possibility.

miiijen, necessity, compulsion.

jollen, moral obligation (also hearsay, ( $\mathrm{f} . \S 16: 3)$.

wollen, will, desire, intention.

152. Infinitives, dependent upon molal auxiliaries, never take $\mathfrak{j}^{\mathfrak{u}}$, hence:

id) Darf gchen, I may go. id) muigte gehen, I had to go.

id) werbe gehen tönucn, I shall be able to go. 
Notice that, in the last sentence, the infinitive of the modal auxiliary comes after the infinitive depending upon it.

153. $\Lambda$ modal auxiliary is frequently used with a separable prefix without a dependent infinitive, especially when a verb of motion is implied:

Id) faum ni(f)t mit, I cannot go along.

(Er Darf nifft hitans, he may not go out.

Id fam midft hiuteitt, I cannot get in.

Likewise, sometimes, as an independent verb:

アï̈uten Sie Deutid? Do you know German?

$\mathfrak{W} \mathfrak{a} \mathfrak{z}$ joll $\mathfrak{d a \mathfrak { s }}$ ? What is the meaning of that?

154. In the perfect and pluperfect, the infinitive form (really an old strong past participle) is used, instead of the past participle, when there is a dependent infinitive:

If habe nidgt gefen dïrien, I have not been allowed to go.

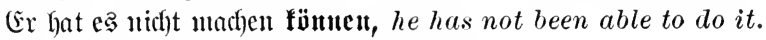

But, Jch habe nidft gedurfî, I have not been allowed.

(Er hat $\mathfrak{e}$ nidf)t gefomut, he has not been able to do it.

155. In dependent clauses, when two infinitive forms stand together, the auxiliary stands before both:

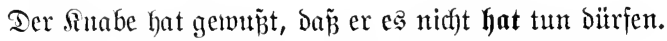

The boy knew that he was not allowed to do it.

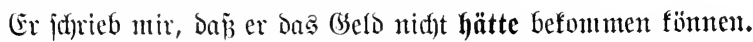

IIe wrote me that he had not been able to get the money.

\section{VOCABULARY}

ber $\mathfrak{A} \mathfrak{u}^{\prime} \mathfrak{g e t h b l i f f} ;$-e, the moment. ber $\mathfrak{M} i i^{\prime} t \overline{t a} \mathfrak{g},-e$, the midday, noon. $\jmath_{\mathfrak{u}}$ Mit't'tāg eî̄en, to dine.

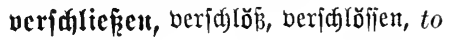
lock. weit, far. gewiê, certain, certainly. \{đjwăd\}, weak. bis, till. jŏnit, else. 


\section{READING EXERCISE}

1. Darf idf ausgehen? Sa, bu barijt heute auzgehen, Sart, benn morgen wirit bu nidjt ausgehen fömnen. 2. STnna bari nicht mit, benn jie fann nicht fo weit gehen. 3. Sönnen Sie morgen abend fommen? Tieitt, morgen abend fann idh nicht, aber idf fann heute abeno. 4. Sarl $\mathfrak{f a n n}$ es ganj gut tum, aber er barf ez nidgt. 5. Die Sinber mögen ihren Snfel nicht, und er mag aud) feine Sinder, jie machen ihm ju viel Särm. 6. Max hat nidft ausgehen birrjen, weil er feine $\subseteq$ fhularbeiten nidht gemadht hatte. 7. Эad habe ign nidht bejudhen mögen, weil

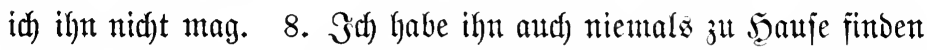
fönnen. 9. Sie hat gedurft aber nid)t gemod)t. 10. Sönnen

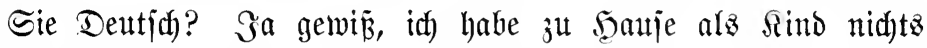
als Deutid) iprechen bïrjen. 11. Эa) habe heute nidft in bie Stadt gefonnt, idf hatte ju viel ju tun. 12. Sd) fonnte nidht hinein, uno er fonnte nid)t herats, Denn bie Tïr war veridhlofijen. 13. $\mathfrak{A} \mathfrak{n} \mathfrak{n} \mathfrak{a}$ fagt, jie bitrje nidgt mitfpielen. 14. Er jagte mir, dá̧ er nidft fommen tönne, meil er nidht auzgehen bïrje. 15. Weil ber snabe jeine ?(rbeit nidht hat mad)en fönnen, ijt er nicht jur @ahule gegangen. 16. Er jagte mir, er hätte bie Shfgabe nid)t j(d)reiben tönnen, weil er jie nidyt veritanden hätte. 17. Sie jadrieb mir, jie hätte bas 3 utd nid)t in Mew Yorf be= fommen fönnen. 18. G(h) mag jeşt nidfts efjen, fonjt werbe id) $\mathfrak{j u}_{\mathfrak{u}}$ Mittag nidytz effen fönnen. 19. Er mod)te nidhtz trinfen, Denn er war nicht buritig. 20. Es mag viefleidgt walyr jein, aber idy fann es nidat glanben. 21. Er jagte mir, er fönne es nidyt glauben. 22. G(h) habe es aud) niemals glauben fönnen.

\section{DRILL}

A. Translate into English: idh barf; id habe nidgt geburft; 
iif) werbe biirfen; er hat gefonnt aber nidht gemodht; er modhte es nicht; er hat es tun mögen aber nicht bitrfen; jie burfte aber jie mochte nidft.

B. Translate into Germun: he may; she was allowed to; he has not been allowed to; I shall be allowed to; we can; I can; I could; he has not been able to; they will be able to; they had not been able to; I like him; he likes me; he did not like it; I did not care to go; I may perhaps go; she will like to go; he has not been able to go; she has not been allowed to go.

C. Give the third person singular of all tenses, indicative and subjunctive, of bïrfen, fönnen, mögen.

\section{WRITTEN EXERCISE}

1. You may go out, (harles, if you like. 2. I do not like to go. 3. She was not allowed to go. 4. Will he be allowed to play with the children? No, the doctor says he may not get up till to-morrow. 5 . He cannot come to-day, but he can come to-morrow. 6. I shall not be able to see him to-morrow. 7. He has not been allowed to get up; he is still too weak. 8. We are not allowed to speak English at home. 9. He did not like to speak German, because he could not speak it well. 10. The children like their teacher, and she likes children. 11. He did not like to visit her, because she did not like him. 12. I have not been able to find the house. 13. The poor boy could not do his exercise; it was too hard. 14. He does not like to work. 15. Because the man has not been able to work, he is very poor. 16. Can you go along? Yes, I can go along, if you can wait for me a moment (acc.). 17. She knows that $I$ have not been able to get the books. 18. He says he is not allowed to go. 19. This poor woman says she cannot find her husband. 20. He may perhaps be here in this town. 21. My father thinks I cannot do it; but I can do it very well. 22. He says that he has not been able 
to find Mr. Brown at home. 23. She says she cannot believe it. 24. She says she has never been able to understand German.

\section{LESSON XLV}

156. Modal Auxiliaries (continued).

Present Indeatrive

ntïffen

(id) mŭriz, I must.

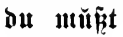

er mŭ̃

wir mü̈ijen

ifhr müißzt

fic mü̈̈̈̈n jŏllen

(id) jŏll, I am to.

bu joullit

er joull

woir jŏllen

ih)r jüllt

jie jüllen wŏllen

idf) will, I will, want to.

bu wưllit

er will

wir wŏllelt

ihr woullt

jie wŏllen

\section{$157 . \quad$ Present Simbenctive}

(id) miijīe, I must. idj jolle, I am to. id wolle, I will want to.

ou miiijejt

bu jollejt

cr mitije

etc.

er jolle

bu wollejt

etc.

er wolle

etc.

158.

Past Indichtive

id) ungete, I had to. id) jollte, I was to, should. id) wollte, I wanted to.

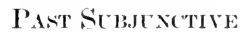

id) miifete, I had to. idf joflte, I ought to, should. idf wollte, I wanted to.

a. Sollen and wollen take no umlaut in the past subjunctive, as they have no umlaut in the infinitive. Hence, in the past tense, the forms are the same in both moods.

159. Miifincn expresses compulsion; but joflen, moral obligation :

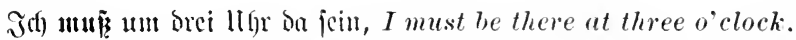

Id) foll an orci llhr ba jeit, I am to be there at three o' clock.

Er mupgte gehen, he had to go; cr jollte gehen, he ought to go. 
160. The English 'could', and 'might' may be indicative or subjunctive; hence, in translating into German, care must be used in selecting the right mood:

I could (indicative) not come yesterday, ich) foutte nicht gejtern tommen. I could (subjunctive) come to-morrow, idh fömte morgen foumen.

Rule: If the English modal anxiliary is in the past tense, expressing past time, use the indicative; but, if the past tense in English is used of present or future time, use the subjunctive.

161. As the modal auxiliaries are used very frequently in the past subjunctive, the following forms with their English equivalents should be memorized:

id) Dïrite, I might (permission), I should be allowed to.

id) föunte, I could, I should be able to, I might (ability).

idf) möd)tc, I should like to, I might (possibility).

idf) miifite, I must, I should have to.

ich folfte, I ought to, I should.

ich) wollte, I should want to.

162. The English 'could have', 'might have', 'ought to have' etc., indicating a condition of things in past time and contrary to fact (cf. $§ 140$ ), are expressed by the pluperfect subjunctive:

ich hätte gefon fömucu, I could (might) have gone (but the fact was I did not go).

idf) hätte gehen bürfen, I should have been allowed to go.

id) hätte gehen mögen, I should have liked to go.

ish $\mathfrak{h a ̈ t t e ~ g e h e n ~ m i i j i ̄ n , ~ I ~ s h o u l d ~ h a v e ~ b e e n ~ o b l i g e d ~ t o ~ g o . ~}$

idf hätte geheu follen, I ought to have gone, should have gone.

ich hätte gehen wollen, I should have wanted to go.

163. (1) Eollen (cf. \$159) may also be used in the sense of 'scid to', 'supposed to':

Er joll fefr reich jein, he is said to be very rich. 
(2) $\mathfrak{G o l f a}$ may be used in the sense of 'pretenil to', 'claim to':

Er will es getun baben, he cluims to have done it.

Also in the sense of 'to be about to', as:

J(h) wollte eben ben Brief joreiben, als er'fan.

I was just about to write the letter, when he came.

164. Besides the modal auxiliaries, a few other verbs (as in English) govern the infinitive without $\mathfrak{z}^{\mathfrak{n} .}$ Some of these, when used with a dependent infinitive, form their compound tenses with the infinitive, instead of with the past participle.

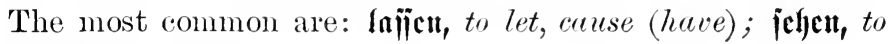
see, hören, to herl:

Jah habe ihn fonmen laijen, I have had him come.

Err hat jie jungen hören, he has heard her sing.

Jah habe ifn foumen jehcu, I have seen him come.

165. $\mathfrak{Q} \mathfrak{n} \mathfrak{j} \mathfrak{n}$ takes an active infinitive with passive meaning: Ja) laije cinten giod undyen, I am having a coat made. Wiein Bater hat bas bans baucn lajien, my father has had the house built.

Compare: My father has built a house, mein $3 a t e r$ hat ein saus gefout. with: My father has (is having) a house built, meit Bater läß̨t eit foan bautr.

\section{VOCABULARY}

bas Billet' (pron. Biljẹt'), -s, -e, jiđ juämcn, to be ashamed of onethe ticket.

leigen, lich, geliegen, to lenul.

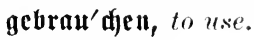

paijen, to fit. self.

Iajien, lieś, gelajien, (er läjit), to let, to have, cause.

id) jübüme midd, I am ashatued of myself.

nus'verfaujen, to sell out. uäđoit, next.

um brci $\mathbf{l l h r}$, at three "clock.

\section{READING EXERCISE}

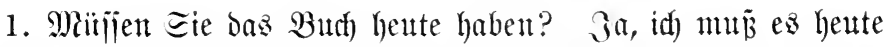
faufen. 2. Sisir follen alle morgen bie Bitdher haben. 3. 3d 
wollte es idfon gejtern faujen, aber Mutter fonnte mir baz (Seld nid)t gebert. 4. Jah jollte bie 9(rbeit heute madhen. 5. Dann bätten Sie bas $\mathfrak{B}$ ud) geitern faufen jollen. 6. Mein Jreund

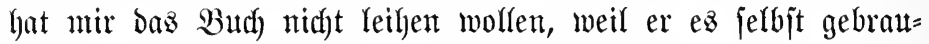
d)en mujte. 7. Miöbten Sie nädjiten Eommer nadh Deutidh=

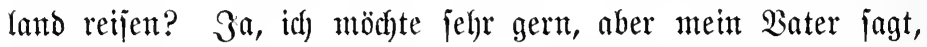

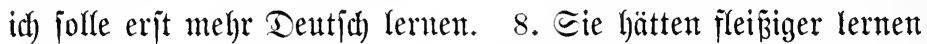

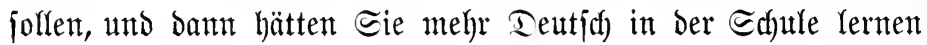
fönnen. 9. Gr hätte ez ganj gut tun fönnen, aber er hat ez nidht tunt mollen, und baher hat er gejagt, er fömne es nicht tum. 10. Saann follen Eie ba jein? Gdh foll um brei uhr ba jeint. 11. Sie bätten fdyon friiher ba jein follen. 12. 1lm jo ein

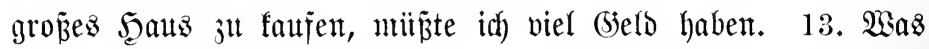

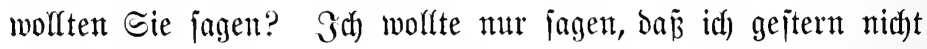

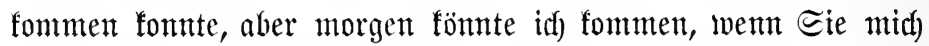

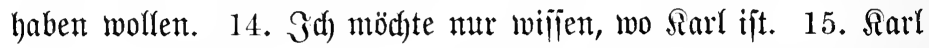

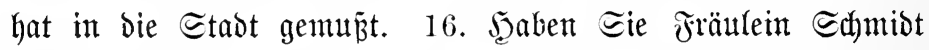
jingen hören? Yiein, idh habe fein Biflet befommen fönnen,

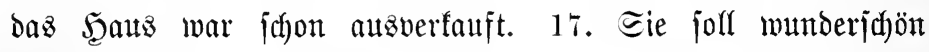
jingen fönnen. 18. Seaben Sie în inz Şaus gehen jehen? Yiein, aber id) habe ihn aus oem şauje fommen jehen. 19. Er hat jidh einen neuen 9iocf madhen lajfen, aber er hat nidht $b a=$ fïr bejahlent fönnen. 20. Er will fo reidh fein, aber er lann niemals jeine 9ied)mungen bejahlen. 21. Er jollte feine Redy= mungen bezahlen. 22. Miein Snfel hat ein grö̈̈erez Şauz bauen lajien miijien, er hätte aber daz alte erjt verfaufen folfen, denn bann hätte er fïr das neute bejahlen fömen.

\section{DRILL}

A. Translate into English: er joll ez madhen; idh jollte ez 
tun; jie hätten es tun jollen; wir muśten gehen; er hätte gehen miifjen; er hat gehen mitijen; Sie merben laujen miijfen; jie hat es nidyt tun wollen; jie ljätte es tun wollen; er wollte mitgelgen.

B. Translate into German: he had to go; she has had to go; I ought to be there; we ought to have been there; thou shalt not steal; I am not to steal; I should like to go; he might be there; she wanted to be there; she will want to go; he is having a house built.

C. Give the third person singular of all tenses, indicative and subjunctive of miijien, jollen, wollen.

\section{WRITTEN EXERCISE}

1. When must you be there? I ought to be there at three o'elock. 2. Then you ought not to have stayed here so long. 3. I had to wait for you; you ought to have come earlier. 4. I wanted to see you, and so I waited. 5. My brother could not come yesterday, but he could come to-morrow. 6. He says he must stay at home. $\tau$. Karl says that he does not want to do it, but that he must do it. 8 . He will have to do it. 9. She could not get a ticket, and so she had to stay at home. 10. Would you like to go? Yes, I should like to go, if I could get a ticket. 11. I did not want to lend him the money, but I had to. 12. I could not do that, if I would. 13. This boy has studied German three years, but he knows very little. He ought to be ashamed of himself. 14. He ought to have written his exereise better. 15. She is said to be very poor, but she can always pay her bills. 16. He pretends to be so young, but he must be an old man. 17. I have had a new coat made, but it does not fit. 18. We have never heard him sing so well. 19. I have never seen him smoke. 20. He ought not to smoke; he is too young. 21. He would like to smoke, but he is not allowed to. 22. I do not want to smoke. 


\section{LESSON XLVI}

166. The Conditional Mood. - The past subjunctive of merben, with the present infinitive of a verb, forms the present conditional; with the perfect infinitive, it forms the perfect conditional.

\section{Active Voice \\ Present Conditional}

id wïrbe loben, I should praise.

Du wiirdejt loben, thou wouldst praise.

cr witrbe loben, he would praise.

wir wïrocn loben, we should praise.

ihr wiirbet Ioben, you would praise.

fie wïrben loben, they would praise.

\section{Perfect Conditional}

id wärbe gelobt haben, I should have praised.

bu wïrbejt gelobt haben, thou wouldst have praised.

$\mathfrak{e r}$ witude gelobt haben, he would have praised. wir wïrben gelobt haben, we should have praised. ihg wïrbet gelobt $\mathfrak{h a b e n}$, you would have praised. fie wïrden gelobt haben, they would have praised.

\section{Passive Voice \\ Present Conditional}

id würbc gelobt werben, I should be praised.

Du wiirbeit gelobt werben, thou wouldst be praised.

cr witroc gelobt werbel, he would be praised. etc.

\section{Perfect Conditional}

id wïrbe gelobt worben jẹin, I should have been praised. bu wirbejt gelobt worben fein, thou wouldst have been praised. cr wiirbe gelobt worben jein, he would have been praised. etc. 
167. (1) The conditional may take the place of the past subjunctive in the main clause of a conditional sentence: (cf. $\S 140)$.

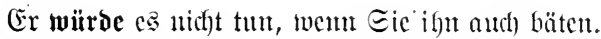
He would not do it, even if you should ask him.

But also: Err täte ess nifht, wem, ete.

(2) The conditional is used most frequently with weak or regular verbs, where the past indicative and past subjunctive are identical, e.g.:

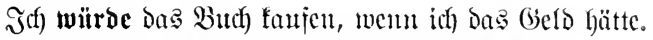

I should buy the book, if I had the money.

168. The perfect conditional may take the place of the pluperfect subjunctive in the main clause of a conditional sentence: (cf. §140).

Ěr wiitre es getan haben, wenn $\Xi_{i c}$ ifn gebeten fä̈tten.

Ile would have done it, if you had asked him.

But also, cr hätte $\mathfrak{e} \mathfrak{g} \mathfrak{g e t a n}$, ete.

Sie wïrbe gelobt worben feen, weun fie filciß̄iger gervejen twäre.

She would have been praised, if she had been more diligent. But also, fie wäre gelobt worden, ete.

\section{Variable Verb-prefixes.}

(1) As stated in $\$ 50$ (1), prepositions used as verb-prefixes are generally separable, but burd), ïbcr, unter, um may he used as separable, or as inseparable prefixes, e.g.:

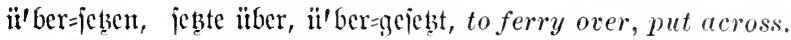
ïberfes'sen, ïberiest'te, ïberjetst', to translate.

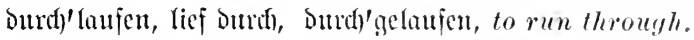
Durd)lau'fen, Dutriflief', Durdflau'fen, to peruse hastily.

Thus: cr jetzte tme iiluer, he set us across.

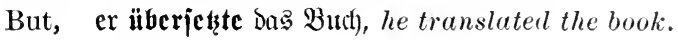


(2) When the verb is used in a literal sense, these prefixes are separable and have the main accent; when used figuratively, they are inseparable, the accent then falling upon the verb stem.

(3) When, however, the preposition has an object, the eonstruetion in German is like that in English; i.e. simple verb and a noun governed by a preposition:

Er fețt un Er lief Durd Den Barten, he ran through the garden.

170. (1) $\mathfrak{X}$ icdor, again, is inseparable in wieberbo'len, when meaning to repeat:

wicberholen Eie Das! repeat that.

But, folen Eie es wicber! fetch it again.

(2) 5iuter, behind, and wiber, against, form only inseparable verbs:

hinterlaj'jen, to bequeath; wioerjte'ben, to resist.

171. Some compound verbs, formed from noums and adjectives, are separable, other's not. These must be learned by usage, e.g. :

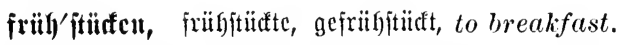

But, frei'fpredjen, ipradh frei, freigefprodsen, to acquit.

hand'haben, hanobabte, gehandiabt, to handle.

But, teil'nchmen, mahm teil, teilgenommen, to take part, participate.

172. As a rule, the separable prefix is detached in the simple tenses and stands at the end of the clause; but the prefix usually precedes a dependent infinitive clause, as:

Er fing an, ben Brief $j^{n}$ Lejen, he began to read the letter. But also, er fing Den Brief $\mathfrak{h}$ lejen an. 


\section{VOCABULARY}

ber Edififer, -, the boatman. ber Midter, 一, the judye.

ber Goldāt', -en, the soldier. Der Feinto, -e, the enemy.

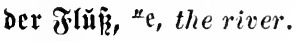
Der Săłz, " bie Ilnterhal'tung, -en, the conversation.

dic $\left.\mathfrak{B e r} \mid \overline{\mathbf{u}}^{\prime} \mathfrak{d}\right) \mathbf{n g},-\mathfrak{c}$, the temptation.

Dả Boot, -e, the boat.

bas Piuber, 一, the oar.

bag $\mathfrak{B c r b r e} \breve{c}^{\prime} \mathfrak{d} \mathfrak{e n},-$, the crime. hinterge'ben, hinterging', hintergan' = gen, to deceive.

rubern, to row. idjiffen, to send. itrajen, to punish. nett, nice. un' $\mathfrak{i d ) u l b i g , ~ i n n o c e n t . ~}$ hust'grig, hungry. ftreng, strict. bewēgt, rough (of water). bit'terlid, bitterly. jogar' nid,t, not even. Daran', next to it.

\section{WRITTEN EXERCISE}

1. Saeinrid), wiubejt bu mitgehen, wenn S(nua mitginge?

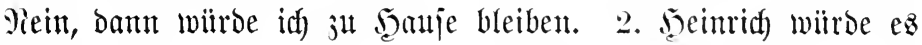

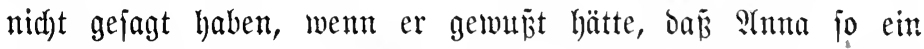
nettes Miäbdhen ijt. 3. Sarl wïrbe bie jdumere s(migabe gemadyt haben, wenn er bie 3eit gehabt hätte, denn er ijt ein jehr flei=

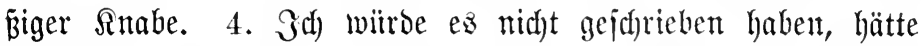

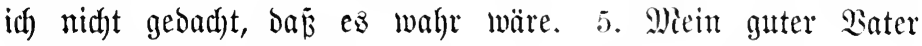
witrde mir (seld fduicfen, went er es hätte. 6. Şätte meine

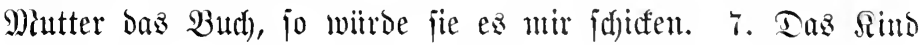
wiirbe nidht jo anartig fein, wenn ber sater jtrenger wäre. 8. Der @ififfer wütrbe unz ïberjetzen, went bas asajjer nidht jo belvegt wäre. 9. Gdh wïrbe gern ben Brief ̈̈berjeben, wenn

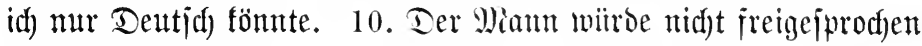
worben jein, wenn er nidyt unjaldoig gewejen wäre. 11. Bitte, ïberjeben Eie biejen Eatz: "Ein Mann jetzte unz in einem fleinen Boote ïber." 12. Wieberholen Eie, bitte, ben 巨ałz! 
Eie jpredhen mir Deutid ju janell, idh fann Sic nidgt verjtehen. 13. Der Yiidfter (prad) Den Mann frei, weil er an bem $\mathfrak{B} e r=$ brechen nidht teilgentommen hatte. 14. Wann fritgjtit(fen Eie

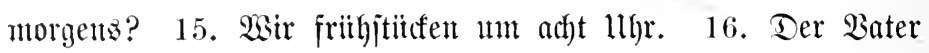

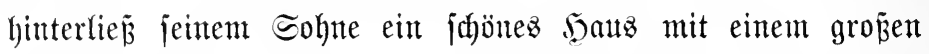
(5arten Daran. 17. Der alte Sajiffer handhabte baz Boot jo

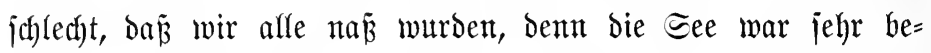
megt. 18. Der Ģund Yief Durdh ben Barten. 19. Der Sohn hinterging feinen Bater. 20. Er ging hinter Dem Bater her. 21. Wir fingen an baz Boot zu rubern, aber wir fonnten bie jaberen Mitber nidjt handhaben. 22. Ilnjere Solbaten wiber= jtanden lange dem Feinde, aber endlid) munten jie wieber ïber Den $\mathfrak{F l u} \tilde{\beta}$ zurïtfjeţen.

\section{DRILL}

A. Substitute in the main clauses of the following sentences the conditional forms for the subjunctives:

1. $\Im \mathfrak{d})$ hätte då (belo, wenn er mich bezahlt hätte. 2. Fr hätte mir bas $\mathfrak{B} u \mathfrak{h}$ gegeben, wenn er ez jelber nidht gebraudht hätte. 3. Mein Sater wäre ba gerwejen, wenn er bie Zeit ge= habt hätte. 4. Wenn jie hier wäre, jähe ich jie. 5. Gab bliebe hier, wenn Sie bleiben. 6. Die Arbeit wäre mun idhon gemadht, hätten wir frïher angejangen.

B. Substitute in the main clauses of the Reading Exercise, subjunctive forms for conditional forms.

\section{WRITTEN EXERCISE}

1. I should do it if I had the time. 2. The boy would learn more German if he were in Germany. 3. He would not have said it if it were not true. 4. We should have seen him if he had been there. 5. Had I the money, I should buy the picture. 6. If I had the book, I should gladly lend it to 
you. 7 . The boy would have been punished by his father if he had done it. 8. Please translate this letter for me. 9. This book is translated from (ałz) the German. 10. Do not deceive me. Has he been acquitted or not? He has been acquitted. 11. Please repeat what you said. I did not understand. I said that the judge had acquitted him. 12. He would not have been acquitted if he had participated in (an, dat.) the crime. 13. My father handled the boat so well that we did not even get wet, although the sea was very rough. 14. Have you breakfasted already? If I had not breakfasted, I should be very hungry. 15. She perused the letter hastily and then began to weep bitterly. 16. Her father had bequeathed to her all his money. 17. The boy resisted the temptation (dat.) and did not copy his exercise. 18. Why do you not take part in (an, dut.) the conversation? Because I cannot speak German. 19. Begin to speak German and you will soon learn it. 20. He would not speak German so well if he had not tried to speak it.

\section{LESSON XLVII}

173. Cardinal Numbers.

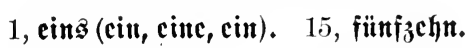

2 , з

3 , orci.

4 , vier.

5 , füní.

6, fed):

7 , jieben.

8 , adit.

9 , teult.

10, zehti.

$11, \mathbf{c l f}$.

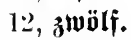

13 , orcizchn.

14 , vicrzehn.

$16,[\mathfrak{e r d}) 3 \mathfrak{c h n t}$.

17, jiebzelin.

$18, \mathfrak{a t d i t} \mathbf{z} \mathfrak{c h})$.

20, jwanzig.

30, brcip̈ig.

4(), vierzịn.

50, fïnfizị.

60 , icd $)$ ig.
19 , nеunzehn.

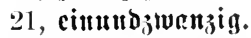

$22, z^{\text {wciundzwanjig. }}$

23 , orciundzwanjig.

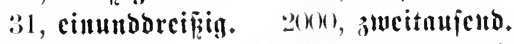

$1(x),(k)$, hunberttaujent.

70, jicbzig.

s(), adit tig.

(9), neunjig.

1(n), hunbert.

101, humbertunbcins.

102, hunbertundjwci.

115, hunbertunofïufjchu.

1:2), huแbertut»juanjig.

?(x), 3wciljunbert.

lexk), tanjento.

1,000,000, cinc Miillion'.

$\because, 000,000$, jwei Millionen. 
a. Sin is the only cardinal number which is declined: idf habe mur cinc $M$ arf uto nidht z'wei, I have only one mark, and not two; es ift brei Fui lang, it is three feet long (nouns of weight, measure etc., are used in the singular form, see lesson XXXI, 91).

$b$. With humbert and taujend the indefinite article is generally omitted: hutbert Dollar, a hundred dollars; tanfent Marf, a thousand marks.

c. With $\mathfrak{m a ̄ l}$ are formed numeral compounds, as: ein'māl, once; 子'wei'mâl, twice; brei'mtăl, three times, etc.

174. Expressions of Time. - In expressing time in German, the half hour and the quarter hour are counted towards the coming hour (as in English in distances, 'half way to', ' $a$ quarter of the way to').

Cin $\mathfrak{B i c r}$ tel brci, or ein Biertel anf brei, a quarter past two.

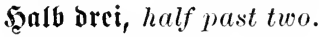

Drei Biertel brei, or anj brei, quarter to three.

Note. The quarters may also be expressed as in English:

cin Siertel nad) vier, a quarter past four.

cin Biertel bor fïnf, a quarter to five.

The minutes are expressed by vor (before, to) and nad) (after, past):

Behn Mitu't'ten vor brei, ten minutes to three.

Bmanjig Minuten und Drei, twenty minutes past three.

175. Ordinal Numbers.

1 st Der, bic, bas erite.

2nd " " " zweite.

$3^{\text {rd }} "$ " " Dritte.

$4^{\text {th }} "$ " " vicrte.

$5^{\text {th }} " \prime \prime \prime$ fïufte.

$6^{\text {th }} " \prime \prime \prime$ jedjjte.

7th " " "fiebte.

8 th " " " adfte.

9th " " " neunte.

10th " " " zehute.

$11^{\text {th }} "$ " " elfite.

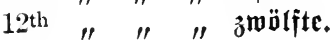

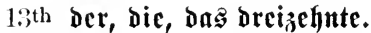

$14^{\text {th }}$ " " " vierzehnte.

"oth " " " zivanjigite.

$21^{\text {st }} "$ " " cinunozwanzigite.

30th " " " Dreipizigite.

31st " " ciunuborcip̧igite.

4 (1) th " " vicroigite.

$50^{\text {th }} "$ " " fïnfzigite.

100 th " " " hunbertite.

10) 1 st " " hunbert unb erite.

200 th $"$ " " zweifundortite.

$1000^{\text {th }} "$ " " taujendite. 
(1) As seen above, the ordinal numbers from two to nineteen are formed from the ardinal numbers by adding $t$, and from twenty upwards, jt. They are leclined like adjectires, being usually preceded by a ber or eill word: ber brit'te Mann, the third man; jein jwei'te fint, his second rhild; igre vier'te Iajje Tee, her fourth cup of ter.

a. Dritt offers a slight deviation from the rule, which wonld give oreit; adyt adds $\mathfrak{e}$ only.

(2) The fractions (except bie Sä̈lf'te, the hulf $)$ are formed by adding tel (Ieil, purt) to the ordinal stem (minus its final $\mathbf{t}$ ): ein Drit'tel, a third; orei Bier'tel, three fourths (quarters); ein Belin'tel, a tenth; ein 3iwan'jigitel, "tuentirth.

(3) Ordinal adverbs are formed with cus, as: eritens, firstly;

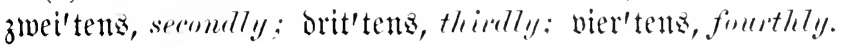

176. Expressions of Date. - In giving the day of the month, the English 'of' must not be translated:

\section{Secute ijt ber erite Mini.}

To-day is the first of May.

\section{Gejtern war ber cinutbjwanjig|te Jănuār.}

Yesterlay was the twenty-first of .Jumury.

(1) In giving a date, the preposition am (an Dem) may be used, as:

Pun eriten Mari murbe er geforen, he was born the first uf May.

An accusative of time (see lesson XXVII, 81) may also be usecl:

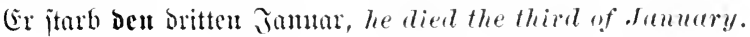

(2) The names of the days of the week and of the months are all masculine and are generally used with the article, as:

Er fam aut (an Dent) Miontāin, he came on Monduy.

(E⿱ 
177. Names of Months and Days:

Эăıนй $\mathfrak{r}^{\prime}$, January

Tẹ̌uruāx', February.

Miär $\mathfrak{r}_{\boldsymbol{j}}$, March.

Aqurì', April.

Mini, May.

In'ıi, June.

Eั̆แน'tāy, Sunday.

Miōn'tāy, Monilay.

Diens'tāg, Tuesday.

Miitt'wŏd), Wednesday.
Ju'li, July.

:(uguit', August.

Gcptem'ber, September.

Dlto'ber, October.

Monen' 'ler, November.

$\mathscr{D e} \mathfrak{e m}^{\prime} \mathfrak{b e r}$, December.

Doutucrstāg, Thursday.

Frrè'tāga, Friday.

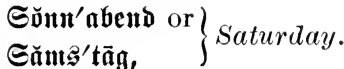

\section{VOCABULARY}

Der (Beburts'tag, -e, the birthalay. ber Ianjent, -e, (the) thousand.

ber $\mathfrak{B a r} \mathfrak{j} \mathfrak{n} \mathfrak{j} \overline{\mathfrak{D}} \mathfrak{f},{ }^{\mathbb{e}} \mathfrak{e}$, the railroad-sta-

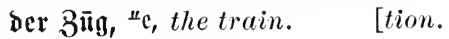
Der $\Re \mathfrak{i} \tilde{n} \mathrm{er}$, - , the trunk. ber $\mathfrak{B f e n n i g , ~ - e , ~ t h e ~ p f e n n i g . ~}$

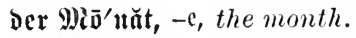
bor $\mathfrak{F a h r p l a ̈ n ,}{ }^{*} \mathrm{e}$, the time-table. ocr (En'wolyucr, 一, the inhabitant. Die Bricimarte, - -1 , the stamp. die Fahrfarte, -n, the ticket (on railroad, ete.).

bic Tajdc, -n, the pocket. die Milliōn', -chl, the million. bas $\mathfrak{s u n d e r t , ~}-\mathfrak{c}$, the hundred. bas $\mathfrak{L e}^{\prime} \mathfrak{b c u s j a h},-\mathfrak{e}$, the year of one's life.

$\mathfrak{a n}$ '́tontmen, fam an, ijt angefonmen, to arrive. $\mathfrak{a} \tilde{f}^{\prime} \mathfrak{g e b c n ,}, \mathfrak{g a b}$ auf, aujgegeben, (gibt auf), to check.

gebōren, born.

$\mathfrak{u} \mathfrak{n}^{\prime} \mathfrak{g} \mathfrak{c} \mathfrak{c a ̈ h} \mathfrak{r}$, about. ridytig, right, correct.

heute $\mathfrak{i b e r} \mathfrak{a d j t}$ Tage, a week from to-day.

heute vor adjt $\mathfrak{T a g e n ,}$ a week ago to-day.

heute ïber vierzehn $\mathfrak{T a g e , ~ t w o ~ w e e k s ~}$ from to-day.

heute vor viergehn Tagell, two weeks ago to-day.

ben wievielten haben wir heute? what date is to-day?

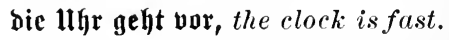
bic $\mathfrak{l l h r} \mathfrak{g c h} \mathfrak{d} \mathfrak{u n d}$, the clock is slow. M)ïn'd)n, Munich.

Baris', Paris.

\section{READING EXERCISE}

1. Sarl, hajt bu (Sels? Sa, Matter, idf habe brei Mart fïnfunozlwanjig Fiennig. 2. 2(m Montag Gattejt bu nod fünf 
Marf, waz hajt bu mit beinem (Selse gemad)t? Yiun (uell), bas Buth hat mid) eine Wiarf gefojtet, Dann labe idh einen $B(e i j t i j t$ fiir zefn Fínenig gefaujt uno eine fïnjpjennig Briefmarfe. 3. Das mad)t jufammen eine Mianf fümjachn Pijennig, brei Mark fïmfunbjwanjig Ffennig hajt bu in ber Tajhe, fïnf Marf hajt du gehabt, aljo fehlen nod) jed)jig Fifennig; wo jino bie? Finnjzig Rijennig habe id) am Sienjtag einem Freunde geliehen, er will jie mir am Freitay juritafgehen, und fiit jegn Fifennig habe id) Ïpfel gefauft. 4. Sater gibt mir Den erjten Des Mionatz immer fiinf Miarf, unb heute ïber adjt Tage haben wir ben eriten. 5. Seute vor adjt Iagen war ber adjtjelnnte Samuar, ez war ber Beburtatan meines Brutbers. 6. Er murbe im Gahre adtjebnlyumbert fïnfundneunjig geboren. 7. Lism waren Eie

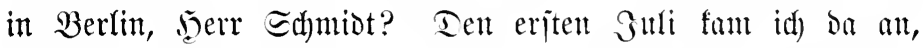
blieb adyt Tage ba, und reijte am adten 3 ult nad) Tresoen. 8. Wie viel llhr ijt ez? EB ijt halb fïnj nad) (according to) biefer llhr, aber bie llyr geht jehn Wimuten vor, aljo ijt bie ridhtige 3eit jwanjig Mimuten nad) vier. 9. Miiijen હie um halb ad)t ober um brei Biertel adyt ba jein? Shl muj um ein Biertel ad)t fdyon ba fein, Denn ber 3̆ty fährt jwanjig Mimuten nach jieben. 10. Şaben Sie einen Fahrplant? Yiein, aber id

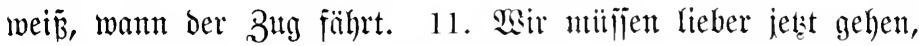

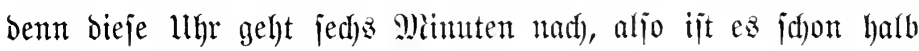
fieben. 12. Friebrid) Edjiller murbe den jehnten Tovember jiebjehnhumbert neunumbfïnjig geboren und jtarb ben neunten Mai adjzehnhundert fïnf, im jechsundvierjigjten Pebensjahre. 13. Er hat taujend Dollar für bas Billo gegeben, aber es ijt feine humbert Doflar mert. 14. Tie Etabt hat eitte \$lifllion Einwohner. 


\section{DRILL}

A. Read the following numbers in German: 8, 10, 12, 25, $33,47,56,64,75,83,99,103,127,561,787,1908,1186$, 30180, 456977, 79837 .

B. Translute: laalf past two; quarter to three; quarter past seven; half past nine; ten minutes past twelve; twenty-five minutes to three; half past one; quarter to eleven.

C. Read the following dates in German: 6 th May 1908; $13^{\text {th }}$ January $1909 ; 15^{\text {th }}$ March $1910 ; 27^{\text {th }}$ April $1898 ; 4^{\text {th }}$ July $1770 ; 26^{\text {th }}$ February $1905 ; 30^{\text {th }}$ June $1828 ; 10^{\text {th }}$ August $1858 ; 22^{\text {nd }}$ September $1610 ; 17^{\text {th }}$ October $1568 ; 25^{\text {th }}$ November $1402 ; 25^{\text {th }}$ December 1911.

\section{WRITTEN EXERCISE}

1. One German mark has a hundred pfennigs. 2. A dollar is about four marks. 3. Twenty-five cents are therefore about a mark. 4. Five dollars are about twenty marks. 5. A hundred dollars are about four hundred marks. 6. This book costs fifteen marks and fifty pfennigs. 7. Have you a tenpfennig-stamp? No, but I have two five-pfennig-stamps. 8. When does the train go? At half past two, but we must be at the station at two o'clock, for we must buy our tickets. 9. How much is the ticket? Three marks, seventy-five pfennigs. 10. This clock is five minutes slow; it is already half past one. 11. What date is to-day? The sixteenth of January. 12. A week from to-day I shall be in Berlin, and on the twentyseventh I shall go to Dresden, where I shall stay till the (bis jum $)$ fifteenth of May. 13. When am I to be there? You are to be there at a quarter to four, as the train goes ten minutes to four. 14. I was at the station at quarter past eleven, and the train arrived at twenty-five minutes past eleven, so I had time enough to check my trunks. 15. How much did you pay for the trunks? One mark, eighty-five pfennigs. 16. Two 
weeks from to-day we are going to Munich and shall stay there till the fourth of July. 17. We cannot stay there longer, for we must be in Paris on the fifth. 18. I saw him last Monday, and he told me he would be at home on Wednesday and Thursday. 19. I shall be at home on Sunday, the whole day. 20. He paid only sixty-two marks for this picture, but it is worth twice as (jo) much. 21. Goethe was born the $28^{\text {th }}$ of August, 1749, and died the 2\%nd of March, 1832; therefore, in his $83^{\text {nd }}$ year.

\section{LESSON XLVIII}

\section{USE OF THE CASES}

178. The Adverbial Genitive is used to expless time, place, manner:

bes Miorgens, in the morning (see lesson XXVII, s()). redfter $\mathfrak{5 a t t o}$, on the right hand. glït(idf)erweije, luckily.

er ging feittes $\mathfrak{B} \mathfrak{e g e s ,}$, he went on his way.

179. The Partitive Genitive is used when an adjective stands before a qualifying noun:

cine Tafïe warmen $\mathfrak{T} \mathfrak{c}$ s, a cup of warm tea.

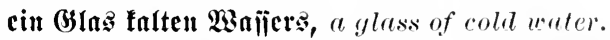
cin Stituf trofinen Brotes, a piece of dry bread (hnt: cime Iajie Ice, cin Błas \$safjer, cin Etitd Brot; see lesson XXXI, 91 (1).

For list of verbs governing the Genitive, see Appendix.

180. The Dative of Possession is often used in place of the possessive pronoun, in referring to prarts of the boly or articles of clothing:

Mir tut ber fiopi mek, my head arhes.

Jit) bahe mir ben finger nerrent, I have sprained my, finger.

Du hajt bir ben Sivt jerrifien, you hate torn your coat.

Equivalent to: Miciu Siof, uciucu Jinger, bcincu Hod. 
181. The Dative of Separation is generally translated by the English 'from':

(Er nathm ifyr Das Buth weg, he took the book from her.

(Er lief wir wey, he ran away from me.

Der Dieb hat ihm bas belo gejt oflen, the thief stole the money from him.

This dative is commonly used with verbs having the prefix cut, as:

Das $\mathfrak{B}$ ort ijt mir cutfallen, the word has escaped me.

Der Berbredher ijt bem befängnijife entiprungen, the criminal has escaped from the prison.

182. The Ethical Dative expresses the interest of the speaker in the action of the verb, and is used mainly in colloquial German. It is generally left untranslated in English, though the following are illustrations of how its force at times may be indicated:

Fall mir nidft bie Ireppe himmuter! Mind you don't fall down stairs. Somm mir mal her! Just come here.

Eiflecibe mir bie Stufgabe glut! Mind you write the exercise well. Edflafe mir nidht ein! Mind you don't fall asleep.

183. Accusative of Time (see Lesson XXVII, 81).

184. The Absolute Accusative is employed in phrases having no direct grammatical dependence upon any verb:

Err jtand ba beı Şut in ber Şand.

IIe stood there with his hat in his hand.

Den Degen in der Şand fitirzte er ins 3 immer.

He rushed into the room, sword in hand.

185. Double Accusatives. The following verbs require two accusatives, one of the person and the other of the thing:

frāgen, to ask. Mennen, to call. idhelten, to scold.

heisien, to bid. făjten, to cost. iđjimtpien, to call names.

lehren, to teach. 
Er fragte midy bas, he asked me that (but, er antmortete mir bas, he answered me that).

Der $\mathcal{L}$ hrer nante ihu einen fleibigen Jungen, the teacher called him an industrious boy.

Er lehrte nid) Das Ed)wimnen, he taught me suimming.

(E⿱ fojtet midy cinent Iollar, it costs me a dollar.

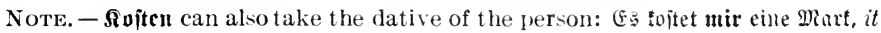
costs me a mark.

186. Verbs governing the Dative Case. - Many verbs in German apparently govern the dative case (i.e. take the object in the dative). With many of these verbs, however, the dative is really an indirect object, the direct object being lacking: Selfen Eie mir! Help, me. Sergib mir! Forgive me.

This is apparent when a direct object is used:

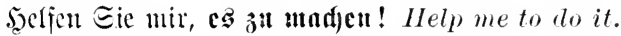

Bergib mir meiute Sdutlo! Forgive me my fault.

Note. - For lists of verbs governing the lative case, see Appendix.

187. Summary of the most common Uses of Cases.

\section{Nominative}

Der $\Omega$ nabe ift nidft hier (subject nominative).

Er ift ber $\subseteq_{o h n}$ meinez Freundez (predicate nominative).

\section{Genitive}

Da ift daz $\mathfrak{B u} \mathfrak{d}$ meinta $\mathfrak{B a t e r s}$ (possessive genitive).

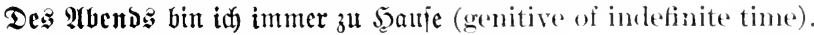

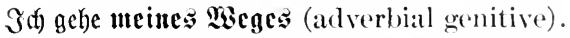

(beben Eie mir cin Glaz falten 2 sajjers (partitive genitive).

Er erimert fidi) uteiner (genitive governed ly verb).

Begen bes $\mathfrak{B e t t e r s}$ bleibt er zu Sauje (genitive with preposition). Wir find bes $\mathfrak{W a r t e n s}$ mübe (genitive with adjective).

\section{I).TTIE}

Sa) gebe bent Miante baz Geld (dative of indirect object).

Mir tut ber Ropf weh (dative of possession). 
Er nahm utir ben $\mathfrak{S} u t$ (dative of separation). (beh utir nidyt aus dem baule (ethical dative).

Der Bater half bem Solnt (dative governed by verb). Eie ift in beul Bimmer (dative with preposition). Er blieb mir tren (dative with adjective).

\section{Accesative}

Fr fauft cinten $\mathfrak{5 u t - ( a c c u s a t i v e ~ o f ~ d i r e c t ~ o b j e c t ) . ~}$ Den $\mathfrak{T a g}$ war id zu Şauje (accusative of definite time). Dan ganzen $\mathfrak{I a g}$ fpiclt er (accusative of extent of time). Den Storf in ber Şand ftand er ba (absolute accusative). Er nannte ifn ciuten Efel (verb takes two accusatives). $\mathfrak{W} \mathfrak{i r}$ liefen

\section{VOCABULARY}

Der $\mathfrak{R a f} \mathfrak{f} \mathfrak{f e c}$, the coffee. ber $B$ cttler, 一, the beggar. ber Sditritt, -e, the step. idneflen Sdjrittes, with quick steps.

ber $\mathfrak{I} u n g e,-n$, the boy. Der $\mathfrak{s} \mathfrak{a} \mathfrak{a l p e l} \mathfrak{l}_{3},-\mathrm{e}$, the lazy fellow. Der Dieb, -e, the thief. die $\mathfrak{P}(\mathfrak{b}$ 'fint, -ent, the intention. die $\mathfrak{B o ̈ r} \mathfrak{e},-n$, the purse. bie $\mathfrak{B c i f c},-n t$, the way, manner. idjeltcu, f(halt, gejdyolten, (jajilt), to scold.

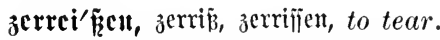
vergebel, vergab, vergeben, (vergibt), to forgive.

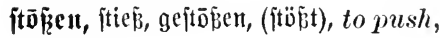
knock. fteflen, jtahl, gejtohlen, (jtieflit), to steal.

beižct, bī̄, gebifien, to bite.

(id)wimuten, fichamm, ift gefdrwom= men, to swim.

Das Sdfwimmen, (the) swimming. (iid) fïrdften (bor, dat.), to be afraid (of).

$\mathfrak{a} \mathfrak{f}^{\prime} \mathfrak{p a j i} \mathfrak{e n}$, to pay attention. weh tun, tat weh, weh getan, to hurt, ache.

fŭnit, else, otherwise. - jăa, why. licber, rather. $\mathfrak{h}$ ôflid, polite. 一 trodten, dry. je'lig, deceased, blessed, late. -fröhlid, cheerful. int Freicn, in the open air. Den $\mathfrak{g} \mathfrak{a} \mathfrak{j} \mathfrak{e n} \mathfrak{T} \overline{\mathfrak{a} g}$, all day.

\section{READING EXERCISE}

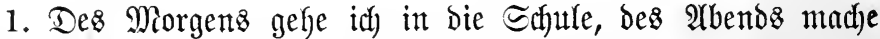
id) meine Edylutarbeit. 2. (s)litflichermeije hatte idh bield bei 
mir, aljo fonnte idh bie Micd)mung bejahlen und meines sieges gehen. 3. Ednellen Ed)rittes eilte cr nad) Şauje. 4. (5eben Sie mir, bitte, eine Iafje warmen Tees, Denn idh habe bent ganjen Tag nidjtz getrunfen als ein (5tas falten $\mathfrak{s a j j e r s . ~}$ 5. Diejer @tubent hat jo viel jutbiert, baj ihm jein Sopj weh

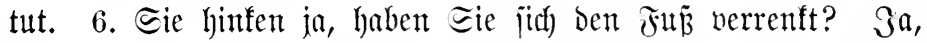
idf bin bie Treppe hinuntergefallen uno habe mir ben rechten

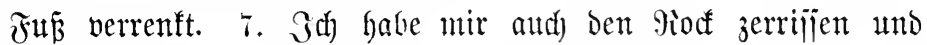
bin mit bem গopf aufgejhlagen. 8. Ter Dieb nahm ihm bas (beld aus ber Tajde. 9. Ter Ģund ijt mir meggelaujen, er wirb aber wohl jdjon wieberfonmen. 10. Sarl, fonm mir nidyt ju jpät

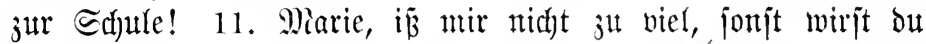
mir noch frant! 12. Sinder, paßjt mir gut auf!/13. Cein Sater fdalt ihn einen faulen Gungen und namte ifn einen Faulpel $\mathfrak{j}_{3}$. 14. Tas $\mathfrak{B u d}$ hat midh einent Dollar getojtet. 15. Die Peh $=$ rerin lehrt bie Sinder bas Eingen. 16. Er fam ins మimmer ben $\mathfrak{S} u t$ in ber Şand und nifyt auf bem Siopfe, bent er war ein ljöflider Gunge. 17. Sergeben $\Xi$ ie ihm, benn er hat es nicht mit a(bäidyt getan. 18. Gah) babe ihm nicht belfen fömen, benn jeine $\mathfrak{G}$ ufgabe war mir aud) ju j(h)wer. 19. Erimern હie (id) nod) meines jeligen saters? Sa gewiz, idh habe ilhn jehr gut gefannt. 20. Der alte :ehrer erimmerte jith nod) meiner, benn er hat mid) frïher Teutid) gelehrt und hat mir aud) oft bei meinen arbeiten geholjen.

\section{DRILL}

A. Form sentences containing 1) a dutire of indirect olject; 2) a dative of possession: 3) "dative "f sepuration; 4) an ethical dative.

B. Form sentences with verbs requiring two accusatives. 
C. When is an accusative of time "sed" "hen a genitive of time?

D. Form a sentence containing 1) a partitive genitive; 2) an adverbial genitive.

\section{WRITTEN EXERCISE}

1. Are you at home in the evening? Yes, you will always find me at home in the evening, except Saturday evening. 2. Do you sleep well at night? Yes, if I am in the open air all day. 3. Unluckily I had forgotten my purse, and therefore I could not pay for the book. 4. I gave the old beggar some money, and he went cheerfully on his way. 5. Will you drink a cup of warm tea, or would you rather have a cup of warm coffee? I would rather drink a glass of cold water. 6. Give me a piece of dry bread for the dog. 7 . I have read so much that my head aches. 8. Did you sprain your hand when you fell down stairs? No, but I sprained my foot. 9. Put the money into your pocket and do not lose it. 10. My mother took the book away from me. 11. She must keep the $d o g$ in the house, otherwise he will run away from her. 12. This man is a thief; he has stolen the money from me. 13. Mind you, do not come home so late this evening. 14. Mind you do not tear your dress. 15. Mind you don't run too fast. 16. His mother called him a good boy. 17. How much did the picture cost you? It cost me very little; I forget what I paid for it. 18. He came into the house, the stick in his hand, and the dog bit him in the leg. 19. My father helps me to do my exercises, for they are too difficult for me. 20. Forgive him; he is ill and does not know what he is saying. 21. I am asking you what you said, but you clo not answer me. 22. I have not been able to teach him swimming, for he is afraid to go into deep water. 


\section{LESSON XLIX}

\section{REVIEW (LESSONS XLIV-XLVIII)}

188. 1. Give the six molal anxiliaries with their prineipal parts and their English meanings.

2. When should one translate 'will' hy werocu? When by woflen? Form two sentences illustrating this.

3. When should one translate 'may' hy bürien? When hy mögcn? Form two sentences illustrating this.

4. What does 'idf mör(fte' mean?

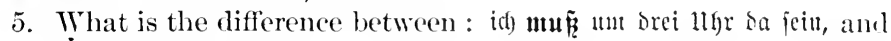
idi) jơl tum brei $\mathfrak{l l g} r$ ba jein?

6. Translate: er jolf jefrr reidy jein.

7. Does an infinitive depending on a modal auxiliary ever take $\mathfrak{u}$ ? Form a sentence to illustrate the rule.

8. Which modal auxiliaries take the umlant in the past subjunctive? which do not?

9. Give the rule for: idf habe gefonnt, but idf habe gehen föuncu.

10. In the case of the compound tenses of modal anxiliaries, what exception is there to the rule that the auxiliary verb stands at the end in a dependent clause? Illustrate by example.

11. When should one translate 'could' by founte? When by fönute?

12. Give the German for: I could go to-day. I could not go yesterday. He must go to-morrow. He is to go to-morrow. She might have done it yesterday. She would like to do it. We should have liked to go. They ought to come. They ought to have come. I did not care to see him. He will come to-morrow. IJe wants to come to-morrow. I have seen him go. He has had a coat make.

189. 1. How is the present eonditional formed? How the perfect conditional? Give examples.

2. What tense of the subjunetive can take the place of the present conditional, what tense that of the perfeet conditional in main clauses of conditional sentences? Illustrate this in the following sentences:

(Er wärbe es nid)t tun, veun man ihn nid)t bittet.

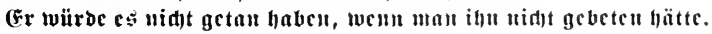

190. 1. Which verbal prefixes are sometimes separable and sometimes not? 
2. Give the rule for distinguishing separable verb-prefixes from inseparable by the accent, and illustrate by example.

3. Translate: Bitte, überietzen ङic! and Bitte, feţen ङic mid über!

191. 1. Name the months and the days of the week.

2. Count from one to one hundred in German.

3. Give the ordinal numbers from one to fifty.

4. Tell in German what date it is to-day and what time.

192. Give as many uses of each case as you know, illustrating each usage in a sentence.

\section{Qejeitiuléc.}

\section{Die Sterne* der 2iadht.}

Ilno bie Sonne mady)te ben weiten Mitt

Ilm bie Welt,

Uno bie Sternlein ipradjen: „Wir reijen mit

$4 \quad$ Ilm bie $\mathfrak{B e l t} ; “$

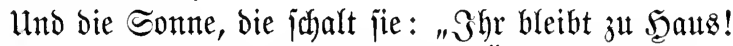

Denn id) brenn' eudh bie goldenen S̈uglein aus

Bei bem feurigen 9itt um bie $\mathfrak{B}$ elt."

$8 \quad$ llno bie Sternlein gingen jun lieben Mono

Эn ber 2aad)t,

Und jie iprachen: "Du, Der auf Molfen thront

$\mathfrak{n}$ ber $\mathfrak{T a d}$ t,

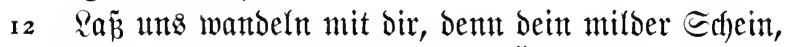
Er verbrennet unz nimmer bie :̈̈ugelein." Und er nahm jie, (bejellen der Paad)t.

S(rnot. (1769-1860.)

* stars. ${ }^{1}$ sun. - long ride. ${ }^{2}$ around the world. ${ }^{5}$ ichelten, fanalt, geicholten, to scold. ${ }^{7}$ fiery. ${ }^{8}$ moon. ${ }^{10}$ clouds. - sittest enthroned. ${ }^{12}$ wander. - shine. ${ }^{13}$ never. ${ }^{14} \mathrm{com}$ rades.

\section{Der weife Lirind.*}

(Es gingen brei Gäger wohl auł bie Birjđ), Sie wollten erjagen den weiñen Şiridh. 
Sie legten jid unter ben Tannenbaum:

4 Da hatten bie brei einen jeltjamen Traum.

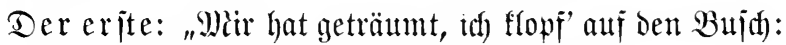

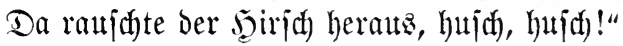

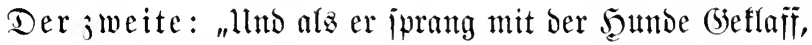

8 Da brannt' idf ihn auf bas Fell, pifi, pafi !"

Der britte: "lind alz idf Den Şirid) an ber Eroe jah ,

Da jtieź idy lujtig inz şorn, trara!“

So lagen jie ba und iprad)en bie brei:

I2 Da rante ber meiñe Şiria vorbei.

lnno eh' bie brei Gäger ihn red)t gejeh'n, So war er bavon ither Tiejen into Seöh'th. Seuf(h), hulf $)$ ! Pifif, pafí I rara!

แthland. (1787-1862.)

*stag. ${ }^{1}$ hunters.- on the hunt. ${ }^{2}$ hunt. ${ }^{3}$ fir tree. ${ }^{4}$ strange.-dream. ${ }^{5}$ I dreamed.

- bush. " ${ }^{6}$ rustle, rush. ${ }^{7}$ barking. ${ }^{8}$ skin (I shot him). ${ }^{10}$ I blew the horn merrily.

${ }^{14}$ valleys, - hills.

5. L̨of̈rung.*

llno bräut ber Minter nod) jo jehr Mit trotzigen (Sjebärben, lind jtreut er Eis und Eantee umher, Es mun bodh Friilgling werben.

llno brängen bie Yiebel nod fo bid)t Sid) nor ben Britf ber Eontule, Sie medfet bod) mit ihrem Qidht Cinmal bie \$selt jur Sismue.

Blajt mur, ihr Etiirme, blajt mit Miandt, Mir joll barob nicht bangen; Suf leifen Eohlen ïber Yiad)t Sommt bod) ber sen; gegangen. 
Da wadyt bie Croe grïnento auf, Seiz nidht, wie ihr geidhehen, llno lad)t in ben fonnigen Seimmel hinauf, 16 llnt mödhte vor :ujt vergehen.

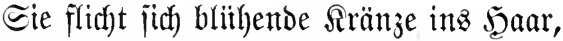
lno jajmit(ft jich mit 9iojen und s̈lbren, llno läß̈t bie $\mathfrak{B}$ rïnnlein riejeln flar, भrla wärent ez Freubenzähren.

Drum ftill! llnd wie es frieren mag, $\mathfrak{D}$ Jerz gib bich jufrieden: Es ijt ein grofier Maientag Der ganjen Welt bejdieden.

Uno wenn bir oft audd bangt unt graut,

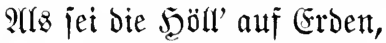
Siur unverzagt auf (Sott vertraut! (E\& muz boch Friühling werben.

(3eibel. (1815-84.)

* hope. ${ }^{1}$ however much the winter threatens. ${ }^{2}$ defiant gestures, bearing. ${ }^{3}$ strews, -ice. - snow. ${ }^{4}$ notwithstanding. - spring. ${ }^{5}$ crowd. - fogs. - however densely. ${ }^{6}$ glance. ${ }^{8}$ rapture, bliss. ${ }^{9}$ blow. - power, force. ${ }^{10}$ You shall not terrify me. ${ }^{11}$ soles ('with light footsteps'). ${ }^{12}$ spring. ${ }^{13}$ (wacht ... auff) awakens. - becoming green ('verdure clad'). ${ }^{14}$ what has happened to it. ${ }^{16}$ would fain die of joy. ${ }^{17}$ weaves. blooming wreaths. ${ }^{18}$ adorns itself. - ears of corn. ${ }^{19}$ brooklets. - trickle. ${ }^{20}$ tears of joy. ${ }^{21}$ however much it may freeze. ${ }^{22}$ be contented. ${ }^{23}$ May-day. ${ }^{24}$ allotted. ${ }^{25}$ horrified. ${ }^{26}$ hell. ${ }^{27}$ undismayed. - trust in God.

\section{Die $\mathfrak{h}$ offnumg.}

Es reben und träumen bie Mienfichen biel • Son befiern fïnftigen Iagen; Siach einem glitcflichen, goldenten Biel Sieht man jie renten und jagen. Die $\mathfrak{B}$ elt wiro alt und wiro wieder jung, Dod) ber Menfiø hofft immer $\mathfrak{B} e r b e j$ jerung. 
Die $\mathfrak{g}$ offinung fiilyrt ihn ins Seben ein, Sie unirlattert ben fröhlichen $\Omega$ naben, Den Süngling locfet ihr Zauberjaein, Sie wirb mit Dem (Sreiz nidft begraben;

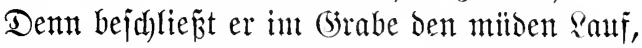

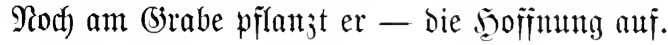

Ez ijt tein leerer idmeidhelnder 2 sahn, Erzengt im Gighine Des Toren.

15 $3 \mathfrak{m}$ Seerjen fitndet es laut jid) an: $\mathfrak{Z}_{\mathfrak{H}}^{\mathfrak{t} \text { waz }}$ Bejerm fint wir geboren, Und was bie innere Etimme ipridft, I8 Das täujht bie hoffende Eeele nidht.

ङd)iller. (1759-1805.)

${ }^{1}$ dream. ${ }^{2}$ future. ${ }^{3}$ happy. - goal. ${ }^{4}$ chase. ${ }^{5}$ world. ${ }^{6}$ improvement (better things). ${ }^{7}$ conducts, leads. ${ }^{8}$ flutters around. - happy. ${ }^{9}$ youth. - entices. - magic lustre. ${ }^{10}$ old man. - buried. ${ }^{11}$ closes. - grave. - weary course. ${ }^{13}$ empty. - flat tering. - delusion. ${ }^{14}$ produced. - brain. - fool. ${ }^{15}$ it announces itself loudly. ${ }^{17}$ inner voice. ${ }^{18}$ deceives. - hoping soul.

5. כ̄wei familiubriefe.

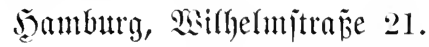
$23^{\text {ten }}$ Miai, 1912.

Piebe @djweiter!

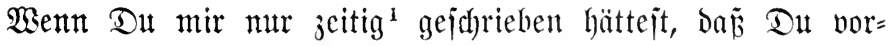

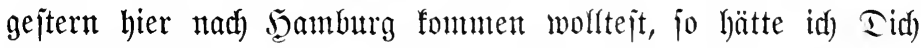

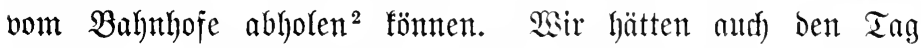
zufammen verbringen ${ }^{3}$ fönnen. Tut hättejt mir aber vierund = zmanjig Stunden eher ${ }^{4}$ idreiben jolfen, Denn idh betonme meine Brieje erjt abends, wenn id) nad) Santje fonme. Eolltejt Tut wieber biejen Mionat jur Etabt fommen, fo jobreibe mir ja bann zeitig. Deinen lieben Brief erhielt idh erit vorgejtern abent,

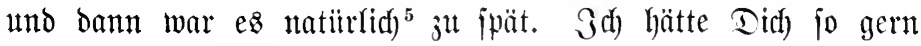
\{prechen mögen. 3 d) lwerbe jetzt wohl ${ }^{6}$ nidjt bor bem vierten 
Guli nach Şauje fommen fönnen, Dent wir werben bieje Tage jehr arbeiten miifien. Soffentlich geht ez der lieben Mutter befifer. $\rightrightarrows \mathfrak{d}$ ) habe ihr gejtern einen langen Brief gejarieben.

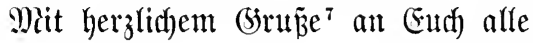

Dein Didy liebender Bruder $^{8}$

Sanz.

${ }^{1}$ in time. $\quad{ }^{2}$ fetch from ('meet at'). ${ }^{3}$ spend. ${ }^{4}$ sooner. ${ }^{5}$ of course. ${ }^{6}$ probably. ${ }^{7}$ with cordial greetings. ${ }^{8}$ your loving brother.

Bitchet.

$27^{\text {ten }}$ Mai, 1912.

Yieber Sanz!

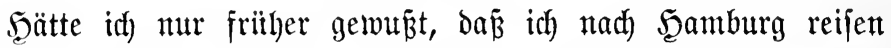
mitîte, jo hätte idh Dir auth frither gejarieben. Seider ${ }^{1}$ war es ju jpät, nod) zeitig genug ju jadreiben, benn id) entidjloź mich ${ }^{2}$ erjt Den Abent vorker. ${ }^{3}$ Die Mitter einter Freunbin von mir jollte näm(tid ${ }^{4}$ in $\mathfrak{S a m b u r g}$ vom Dampfer ${ }^{5}$ abgeholt wer= Den. Den Tag vorher wurbe aber meine Freunbin frant, und jie bat midh ihre Matter abzulyolen. S(ljo jarieb id) Dir nod)

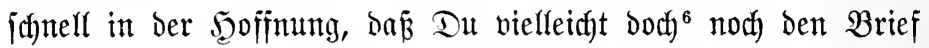
befommen witrbejt, ehe Du morgens aus dem Seauje gingeit. Wir bätten aber bod) nidft ben Tag zujammen verbringen fön= nen, denn bie Mutter meiner Freunbin wollte gleidh ${ }^{\top}$ nach Şauje reijen. Sie fam nümlidh von T(merifa, wo jie ihren Sohn bejufht hatte. Sie ijt eime alte Dame und ijt wenig in Reben

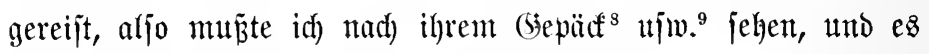
murbe jajon Mittag, ${ }^{10}$ bis wir fertig murben.

Sollte id bieje Tage wieber nad) Şamburg fahren miijfen, jo werbe idf Dir nod) zeitig gemug idreiben. Der Mutter geht es jhon viel beffer, jie wird Dir aber alles jdjon gejąrieben 
haben. Wir jreuten uns j(f)on an ${ }^{11}$ Deinen näd)jen Bejud).

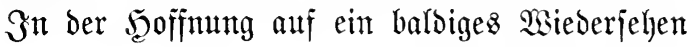

\section{Deine Did liebento Edywejter}

Theffa.

\footnotetext{
${ }^{1}$ unfortunately. ${ }^{2}$ decided. ${ }^{3}$ before. ${ }^{4}$ that is, the reason is. ${ }^{5}$ steamer. ${ }^{6}$ after all.

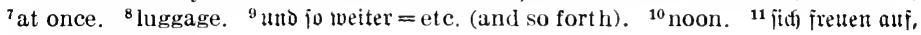
look forward to.
}

\section{6. formeller ${ }^{1}$ Brief. \\ Berlin, Den 2gten Februar, 1911. \\ Berefyrter ${ }^{2}$ jeer Profefijor!}

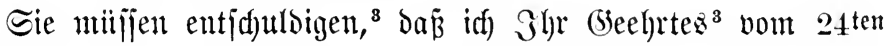

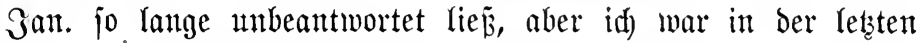

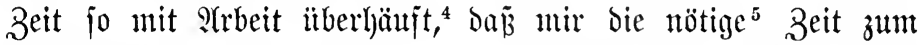

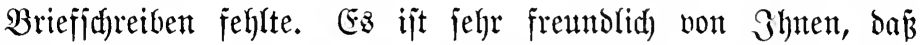
Sie nod) meiner gebenfent, ${ }^{6}$ obgleid) jwei Gahre verjlojīen ${ }^{7}$ jino,

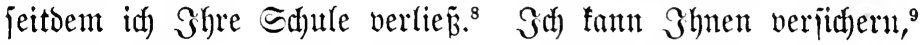

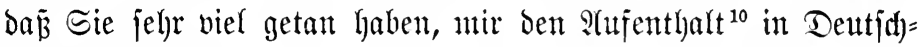

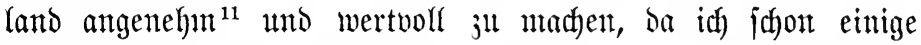

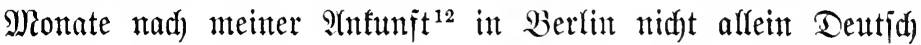
jiemlid) gut berjtelen jonbern aud) ipred)en fonnte. Paad eini=

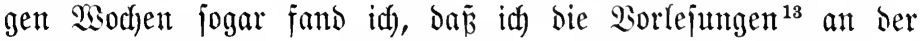
biejigen ${ }^{14}$ llniverjität verjtehen fonnte. Folglidf ${ }^{15}$ brauthte idf nicht, wie viele andere, viel Zeit mit bem Erlernen Der bent=

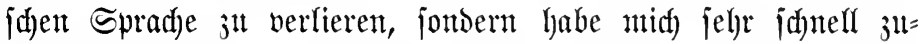
red)tgefunden. ${ }^{16}$ Das Seben gefällt ${ }^{1 i}$ mir hier jel)r gut. Bis jekzt habe id) allerbings ${ }^{18}$ jelgr wentig 3eit gehabt, ins Theater oder in Sonjerte zu gehen, und Sic wififen ja, wie id fïr Miujff

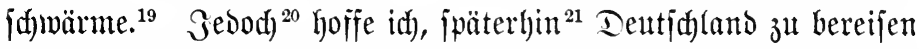

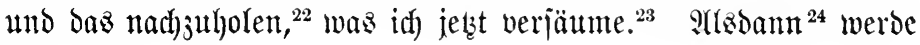


id) Shnen einen längeren Brief idreiben und $3 \mathfrak{h}$ en ausführ $=$ licher ${ }^{25}$ meine (Erlebuifife ${ }^{26}$ erjül)len.

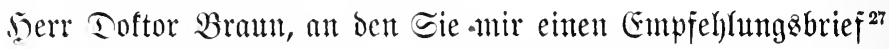
mitgaben, lyat mich fehr frentolich) empjangen und midh gebeten, Sie herźlid ju gritïen. Der Serr Dottor hatte aud bie Freund= lidffeit, midh jeiner Frau (Semahlin ${ }^{28}$ uno Fräulein Töd)tern vorjuftellen. $^{29}$ Эdh habe feitoem mehrere angenehme $\mathfrak{a b e n d e}$ im Sreife ${ }^{30}$ jeiner Familie verbrad)t. ${ }^{31}$ Seien Sie nod)mals her $z=$ (id) bebantt fïr bieje angenehme Befanntja)aft, ${ }^{32}$ bie mir idjon viele Freube bereitet ${ }^{33}$ bat.

Mit Den bejten (Sriijen an Sie, verel)rter Serr Profeffor, wie

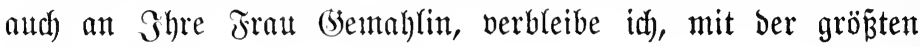
Seodfadftumt ${ }^{34}$

\section{$\mathfrak{h r}$ ganz ergebener ${ }^{35}$}

\section{Willherm Samiot.}

${ }^{1}$ formtclf', formal. ${ }^{2}$ honored, esteemed. ${ }^{3}$ excuse. ${ }^{3}$ your honored (letter). ${ }^{4}$ overburdened. ${ }^{5}$ necessary. ${ }^{6}$ think. ${ }^{7}$ past. ${ }^{8}$ left. ${ }^{9}$ assure. ${ }^{10}$ stay. ${ }^{11}$ agreeable. ${ }^{12}$ arrival. ${ }^{13}$ lectures. ${ }^{14}$ local. ${ }^{15}$ consequently. ${ }^{16}$ got along. ${ }^{17}$ pleases. ${ }^{18}$ to be sure. ${ }^{19}$ how enthusiast.c I am about music. ${ }^{20}$ however. ${ }^{21}$ later on. ${ }^{22}$ to make up for that. ${ }^{23}$ miss. ${ }^{24}$ then. ${ }^{25}$ more in detail, more fully. ${ }^{26}$ experiences. ${ }^{27}$ letter of recommendation. ${ }^{28}$ wife (polite form). ${ }^{29}$ introduce. ${ }^{30}$ circle. ${ }^{31}$ spent. ${ }^{32}$ acquaintance. ${ }^{33}$ prepared. ${ }^{34}$ high esteem. ${ }^{35}$ yours respectfully.

\section{Suggestions for Original Compositions.}

1. Write a description of the school-house; of the school-room; of your house; of your study; of your native town; of the weather.

2. Write a letter to a iriend, asking for the loan of a book.

3. Write a letter of invitation to a friend, asking him to let you know by what train he is coming.

4. Write a letter describing the work you are doing in German.

5. Write out any short stories you may know in German.

6. Write an account of a day at school; of a holiday.

7. Write paraphrases of the German poems and stories in this book. 


\section{APPENDIX}

\section{A. VERB PARADIGMS}

\section{Saber Eciu $\mathfrak{B e r b e n}$}

saben, to have.

Principal Parts: $\mathfrak{h a b e n}$, hatte, gefabt

\section{Present \\ Indicative \\ Subjunctive}

\section{I have.}

idi) babe

bu hajt

er hat

wir haben

ihr $\mathfrak{h a b t}$

fie haben idf babe

bu habeit

er habe

wir haben

ihr habet

iie haben

\section{Perfect}

\section{I have had.}

(id) habe gehabt habe gehabt

bu hait gehabt

habeit gehabt

er hat gehabt

wir haben gehabt

habe gehabt

ihr habt gehabt

haben gehabt

habet gehabt

fie haben gebabt

PAST

Indicative

I had.

Subjunctive

idf hatte

i(f) bätte

ou hattejt

ou hättejt

er batte

er hätte

wir hatten

wir hätten

ihr battet

ihr bättet

fie hatten

\section{Pluperfect}

I had had.

hatte gebabt bätte gehabt

hattejt gehabt bättejt gehabt

hatte gehabt bätte gehabt

hatten gehabt bätten gehabt

hattet gehabt hättet gehabt

hatten gehabt hätten gehabt

Future

\section{I shall have.}

idf merbe haben

bu wirit haben

er wird haben

wir werden haben

ihr werdet habert

fie werden haben

idf werde haben

ou werdeit haben

er werbe haben

wir werden haben

ihr werdet haben

fie werden haben
Futcre Perfect

Indicative

I shall have had.

idf) merde gehabt haben

ou wirjt gehabt haben

er wird gehabt haben

wir werden gehabt baben

ihr werdet gehabt haben

fie merden gebabt haben

Subjunctive

iif) twerde gehabt haben

ou werdeit gehabt haben

er werde gehabt baben

wir werden gehabt haben

ihr werdet gehabt haben

fie werden gehabt haben 
Present Conditional

I should have.

idf witroc haben

bu rüroejt haben

er würde haben

wir würben haben

ihr würdet haben

fie würden haben

\section{Perfect Conditional}

I should have had.

idf mürde gehabt haben

bu würoejt gehabt haben

cr würde gehabt haben

wir würden gehabt haben

ihr würdet gehabt haben

fie würden gehabt haben

Imperative: habe, habt, haben Sie, have.

Infinitive: Pres., haben, to have. Perf., gehabt haben, to have had. Participle: Pres., habend, having. Past, gehabt, had.

\section{Ecin, to be.}

Principal Parts: jein, war, gewejen

Present

\section{Indicative I $\operatorname{am}(b e)$.}

id) bin

ou bijt

er ijt

wir find

ihr jeid

jie jind
Subjunctive

idf jei

du feiejt

cr jei

wir jeien

ihr jeiet

fie jeien

Perfect

I have been.

(id) bin getwejen

jei gemejen

ou bijt gemejen feiejt gewejen

er ijt gemejen jei gemejen

wir juth gemejen jeien gewejen ihr jeio gewejen feiet gewejen fie find getwejen feien gewejen

PAst

Indicative I was (were).

Subjunctive

idf mar

bu warit

er war

wir waren

ihr wart

iie waren idi) wäre

bu wärejt

er bäre

wir mären

ihr wäret

fie wären

\section{Pluperfect}

\section{I had been.}

war gewejen wäre gemejen warit gewejen wäreit gewejen war gewejen wäre gewejen waren gewejen wären gemejen wart gemejen wäret gewejen waren gewejen wären geweien

Future

I shall be.

Indicative

Future Perfect

id) werbe fein

ou wirft fein

er wirb jein

wir werben jein

ihr werdet fein

fie werben jein

id) werde gewejen jein

bu wirit gemejen fein

er wirb gewejen jein

wir werben gemejen jein

ihr werbet gemejen fein

fie werben gewejen jein 
id) merbe fein

ou werdejt fein

er merbe fein

wir werben fein

ihr werbet fein

fie merben fein

Present Conditional

$$
\text { I should be. }
$$

id) rüroc fein

bu mürbcit fein

er mürbe fein

mir würden fein

ihr würdet fein

fie würden jein

\section{Subjunctive}

idf rocroe getwejen jein

ou rocrbejt getwejen fein

er werde gelwejen fein

wir merben getwejen fein

ihr werbet gewejen fein

fie twerben getwejen fein

Perfect Conditional

I should have been.

id) würbe getwejen jein

bu würbejt getweien fein

er mürde gelveien fein

wir wïrden gemejen jein

ihr würdet getwefen fein

fie würden getnejen fein

Imperative: fci, jeid, fiein Sic, be.

Infinitive: Pres., ficin, to be. Perf., gemejen feit, to have been.

Participle: Pres., feiend, being. Past, getwejen, been.

Berben, to become

Principal Pakts: werden, wurde (ward), geworden Present

\section{Indicative Subjunctive}

I become.

id) werde

bu wirit

er wirb

wir werben

ihr werdet

jie werben

idi) werbe

bu werbeit

er werbe

wir werben

ihr rerbet

jie werben
Perfecto

I have become.

idf) bin geworden

fei geworden

bu bijt geworden

jeiejt geworden

er ift getworben

jei getworden

wir find geworden

ihr jeib gemorben

fie find gemorden jeien geworden

feiet getworden

feien geworben

\section{PAST}

Indicative

Subjunctive

I became.

idf lourbe idf würde

bu twurbejt bu würocit

cr imurbe er würbe

wir murben wir würoen

ihr murbet ihr mürdet

jie wurben fic würben

Pliperfect

I had become.

war gewordell loüre geworden

warit getworbell wäreft gelworben war getwordell wäre getworben waren getworben wären geworben wart geworben wäret geworben waren getworden Ivären getworden 
Future

I shall become.

id) werde merben

bu wirit werden

er wirb werden

wir werben werben

ihr merbet werden

fie werben werben

id) werbe merben

ou werbejt werben

er merbe werden

wir merben merben

ihr werdet werden

jie merben werben

Present Conditional

I should become.

idf) würde merden

Du würbejt werben

er würde werden

wir wïrben werden

ihr würdet werben

fie rürben twerben
Future Perfect

Indicative

I shall have become.

idi) werbe gemorben fein

ou wirit geworben fein

er wird getworden fein

wir werben getworben fein

ihr werbet getworben fein

fie werden getworben fein

\section{Subjunctive}

iif) merbe getworben fein

bu werbejt getworden jein

er werbe getworden fein

wir werden getworben fein

ihr werbet geworben fein

iie werben geworben fein

Perfect Conditional

I should have become.

idf rürbe getworben jein

ou würdeft getworben jein

er würbe getworden fein

wir rürben getworben fein

ihr würbet getworden fein

fie würben getworden fein

Imperative: werde, werdet, werden Sie, become.

Infinitive: Pres., merden, to become. Perf., gemorden jein, to have become. Participle: Pres., werdend, becoming. Past, getworden, become.

\section{Weak Conjugation}

Principal Parts: loben, lobte, gelobt

Present

Indicative

I praise.

i(i) Iobe

bu lobjt

er lobt

wir loben

ifh lobt

jie loben
Subjunctive

idf) lobe

ou lobejt

er lobe

wir loben

ifre lobet

fie loben
PAST

Indicative

I praised.

idf) lobte

bu lobteit

er lobte

wir lobten

ihr lobtet

iie lobten
Subjunctive

idi) lobte

ou lobteit

er lobte

mir lobten

ihr lobtet

fie lobten 
Perfect

Indicative Subjunctive

I have praised.

id) habe gelobt habe gelobt

bu hajt gelobt habejt gelobt

er hat gelobt

wir haben gelobt

ihr habt gelobt

fie haben gelobt haben gelobt

\section{Pictperfect}

Indicative Subjunctive

I had praised.

hatte gelobt bätte gelobt

hattejt gelobt bätteit gelobt

hatte gelobt hätte gelobt

hatten gelobt bätten gelobt

hattet gelobt bättet gelobt

hatten gelobt bätten gelobt
Feture

I shall praise.

id) werde loben

ou wirit loben

er wirb loben

wir merden loben

ihr werbet loben

fie werden loben

id) merde loben

du rerdeft loben

er werbe loben

wir merben loben

ihr werdet loben

fie werben loben

Present Conditional

I should praise.

id) würbe loben

bu würdejt loben

er würbe loben

wir mürden loben

ihr würdet loben

fie mürden loben

\section{Indicative}

Frtcre Perfect

I shall have praised.

idf werbe gelobt haben

bu wirit gelobt haben

er Iviro gelobt haben

wir werden gelobt haben

ihr werdet gelobt haben

fie werben gelobt haben

\section{Subjunctive}

icf werde gelobt haben

bu werbeft gelobt haben

er werbe gelobt haben

wir werden gelobt haben

ihr werdet gelobt haben

fie werben gelobt haben

Perfoct Conditional

I should have praised.

idf) würde gelobt haben

ou würdeit gelobt haben

er würde gelobt haben

wir würden gelobt haben

ihr mürbet gelobt haben

fie mürden gelobt haben

Imperative: lobe, lobt, loben Eie, praise.

Infinitive: Pres., loben, to praise; Perf., gelobt haben, to have praised. Participle: Pres., lobend, praising. Past, gelobt, praised. 


\section{Strong Conjugation}

Principal Parts: jingen, fang, gejungen

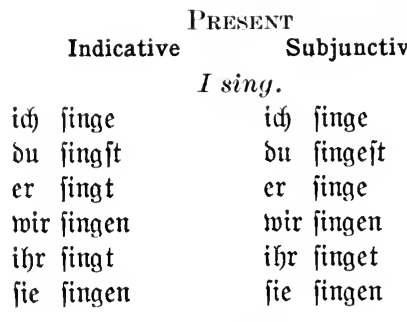

Perfect

I have sung.

id) habe gejungen habe gefungen

ou hajt gejungen habejt gejungen

er hat gejungen babe gefungen

wir haben gefungen haben gejungen

ihr habt gejungen habet gejungen

fie haben gejungen haben gefungen

Future

\section{I shall sing.}

id) werde fingen

ou wirjt fingen

er wird fingen

wir werben fingen

ihr werbet fingen

fie werben fingen

idi) werbe fingen

ou werbejt fingen

er werbe fingen

wir werben fingen

ihr werbet fingen

fie werben fingen

Present Conditional

I should sing.

id) würbe fingen

ou rourbejt fingen

er witrde fingen

\section{Indicative}

Indicative

PasT

idi) jang

bu fangit

er fang

wir jangen

ihr jangt

fie jangen

I sang.

Subjunctive

id) fänge

du fängeit

er jänge

wir jängen

ihr fänget

jie jängen

\section{Pluperfect}

I had sung.

hatte gejungen hätte gejungen

hattejt gejungen hättejt gejungen

hatte gejungen bätte gefungen

hattent gejungen bätten gejungen

hattet gejungen hättet gejungen

hatten gejungen bätten gejungen

Future Perfect

I shall have sung.

id) werbe gejungen haben

du wirit gejungen haben

er wirb gefungen haben

wir werden gejungen baben

ihr werdet gejungen haben

fie werden gejungen baben

Subjunctive

id) werde gejungen haben

bu werdejt gejungen haben

er werbe gejungen haben

wir werben gejungen haben

ihr werdet gejungen haben

fie werben gejungen haben

Perfect Conditional

I should have sung.

idf) würde gejungen haben

bu würdeit gejungen haben

er würbe gejungen haben 
rir würben fingen ihr wübet fingen jie wïrben fingen wir würben gejutgen haben ihr müroct gejungen haben fic würden gefungen haben

Imperative: finge, fingt, fingen Sie, sing.

Ixfinitire: Pres., fingen, to sing; Perf., gejungen haben, to have sung. Participle: Pres., fingend, singing. Past, gejungen, sung.

\section{The Verb gefic conjugated with jeit}

Principal Parts: gehen, ging, gegangen, to go

Present

PAsT

Indicative Subjunctive $\quad$ Indicative
$I g o$.

id) gehe

i(f) gehe

i(f) ging

idf) ginge

ou gehit, etc. bu gehcit, etc.

Perfect

I have gone.

id) bin gegangen jei gegangen bu gingit, etc. bu gingcit, etc.

bu bift gegangen feift gegangen

er ift gegangen jei gegangen

wir find gegangen jeicn gegangen

ihr jeid gegangen jeiet gegangen fie find gegangen jeien gegangen

Pleperfect

I had gone. twar gegangen wäre gegangen warit gegangen wäreit gegangen war gegangen wäregegangen waren gegangen wären gegangen wart gegangen wöret gegangen maren gegangen wären gegangen

-Futere

I shall go.

Indicative

Fctcre Perfec"T

id) werbe gehen

I shall have gone.

bu wirit gehen, etc.

id) werde gegangen jein

bu roirit gegangen fein, etc.

\section{Subjunctive}

(id) merbe gehen

idf berbe gegangen fein

ou werdeit gehen, etc.

bu merdejt geganţen jein, ete.

Present Conditional

I should go.

(id) würbe gehen

Perfect Condtioxil

I should have gone.

idf) würoc gegatngen jeit

bu würbeít gehen, etc.

bu wïrbejt gegangen jeir, ete.

Imperative: gehe, geht, gehen Eic, go.

Infinitive: Pres., gehen, to go. P'erf., gegangen feil, to have gone.

Participle: Pres., gehend, going. Past, gegangen, gone. 


\section{Passive Voice}

\section{Present \\ Indicative \\ I am praised.}

id) werbe gelobt werde gelobt

ou mirit gelobt werdeft gelobt

er wirb gelobt werde gelobt

wir werden gelobt werden gelobt

ihr werbet gelobt werdet gelobt

fie twerden gelobt werden gelobt

Perfect

I have been praised.

idi) bin gelobt worben

ou bijt gelobt worden

er ijt gelobt worden

wir find gelobt morden

inr feid gelobt worben

fie find gelobt morden

id) fei gelobt morden

ou feieft gelobt roorden

er jei gelobt worden

wir feien gelobt worden

ihr jeiet gelobt worden

fie jeien gelobt morben

Future

I shall be praised.

(id) werde gelobt werden

bu wirit gelobt werden

er mird gelobt werden

wir werben gelobt werden

inr werbet gelobt merden

fie werben gelobt werben

id) werde gelobt werden

du werdeft gelobt werden

er merbe gelobt werben

wir werden gelobt werden

ifhr werdet gelobt werden

fie merben gelobt merden

\section{Indicative}

\section{Indicative}

PAST'

I was praised.

wurbe gelobt würde gelobt

wurdeft gelobt würbeft gelobt

wurde gelobt würde gelobt

wurben gelobt würden gelobt

wurdet gelobt würdet gelobt

wurben gelobt ruurben gelobt

Pluperfact

I had been praised.

idf) war gelobt worden

bu warit gelobt worben

er war gelobt worben

wir waren gelobt worden

ihr wart gelobt worden

fie waren gelobt worben

Subjunctive

id) wäre gelobt worden

ou roüreft gelobt morden

er märe gelobt morben

wir wären gelobt worden

ihr wäret gelobt morben

fie wären gelobt worben

\section{Indicative}

Future Perfect

I shall have been praised.

idf werbe gelobt morden jein

ou ririt gelobt worden jein

er wiro gelobt worden jein

wir werden gelobt worden jein

ihr werdet gelobt morden fein

fie werden gelobt worden fein

Subjunctive

iif) werbe gelobt worben fein

bu werdejt gelobt worden jein

er werde gelobt worben fein

wir werden gelobt worden fein

ihr werdet gelobt morden jein

fie merben gelobt morden fein 
Present Conditional

I should be praised.

id) mürbe gelobt werben

bu mürdeit gelobt werden

er mürbe gelobt werben

wir rü̈rben gelobt werden

ihr würdet gelobt werden

fie würben gelobt werden

IMPERATIVE

werbe gelobt, be praised.

merbet gelobt, be praised.

werben Sie gelobt, be praised.
Perfect Conditional

I should have been praised.

idf würbe gelobt worben fein

bu würbejt gelobt worben fein

er rürbe gelobt worden fein

wir würden gelobt morden fein

ihr würdet gelobt worden jein

fie würben gelobt morden jein

Participles

Pres., 孔u lobeno, to be praised (as ad jective only).

Past, gelobt worden, been praised.

Infinitive: Pres, gelobt werden, to be praised.

Perf., gelobt worden jein, to have been praised.

\section{Inseparable and Separable Compounds}

Principal Parts: verfaufen, verfaufte, verfauft, to sell. anreden, rebete an, angerebet, to address.

INSEPARABLE

\section{Indicative}

Present:

i(i) berfaufe

PAST:

Perfect:

id) berfaufte

Ploperfect:

id) habe berfauft

FUTURE:

id) hatte berfauft

Futcre Perfect:

id) rocrbe berfaufen

idf werbe verfauft haben

Subjunctive

Present:

(id) berfaufe

PAST:

Perfect:

id) verfaufte

Ploperfect:

Future:

id) habe verfauft

id) hätte verfauft

iff werde berfaujen

Future Perfect:

Present:

Perfect:

Conditional

idf würde berfaufen

\section{SEPARABLE}

idf rede an

id) rebete an

idf) habe angeredet

idi) hatte angeredet

id) werbe anreden

id) werde angeredet haben

id) rede an

id) redcte an

id) babe angeredet

iif) hätte angeredet

id) werbe anreden

idf merbe angeredet haben

id) wïrbe aureden

idf) mürde verfauft haben

idf witrde angeredet haben

verfaufe

Imperative

verfauft

rede an

rebct an

reden Eie an 
Infinitives

Present: berfaufen ( 3 berfaufen)

Perfect: berfauft haben

anreden (anzureden)

Perfect:

Present:

verfaufend

Participles

PAST:

berfauft

angeredet haben

anrebend

angeredet

\section{Reflexive Verb}

Sid crimtern, to remember.

Principal Parts: (id erinnern, erinnerte fid), (iid erimnert.

Present

Indicative

idf) erinnere mida)

I remember.

Subjunctive

bu crinnerít bid)

idi) erinnere mid)

er erinnert fid.

wir erinnern unz

ou erinnerejt bid)

er erinnere jid

ihr erinnert eud

wir erinnern unz

fie erinnern fitd

ihr erinneret euds)

Sic erinnern fid

PAST

jie erinnern fid

Sie erinnern fid)

I remembered.

(id) erinnerte midi)

idi) crinnerte mid)

ou erinnertejt bidf

bu erinnertejt bid)

er erinnerte fid

wir erinmerten unz

er erimnerte fid)

ihr erinnertet eud)

wir erinnerten unz

fie erinmerten fid

ihr erinnertet eud)

fie erimnerten fid)

Perfect: $\quad$ id habe mid) erinnert, I have remembered

Ploperfect: (id) hatte midi) erinnert, I had remembered

Future: $\quad$ idf werde mid() erinnern, I shall remember

Future Perfect: id) merbe mid) erinnert haben, I shall have remembered

CONDITIONAL: idf würde midf erinnern, I should remember

Condit. Perf.: id würde midf) erinnert haben, I should have remembered

Imperative: erinnere did), remember

erinnert eud), remember

erinnern Sie (id , remember

Infinitive: $\quad$ Pres., fid erinnern, to remember.

Perf., fid erinnert haben, to have remembered.

Participle: Pres., fid erinnernd, remembering.

Past, (ifi) erinnert, remembered. 


\section{The Modal Auxiliaries}

Infinitive

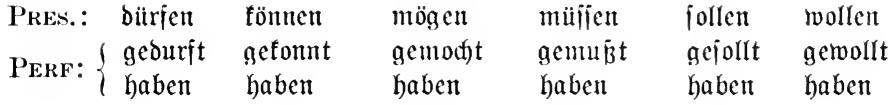
Participle

Pres.: dürfend fömnend mögend müfiend jollend wollend PAsT: gedurft gefount gemod)t gemußist gejollt gemollt or, bürfen fönnen mögen müifen follen wollen

\section{Indicative}

Present

\begin{tabular}{|c|c|c|c|c|c|}
\hline idf) barf & fann & $\operatorname{mag}$ & 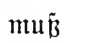 & folf & will \\
\hline bu barift & fannit & magit & muß̃t & jollit & millit \\
\hline er barf & fann & mag & 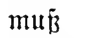 & foll & will \\
\hline wir bürfen & fönnen & mögen & müijen & jollen & mollen \\
\hline ihr bürft & tönnt & mögt & muit $\bar{B} t$ & jollt & wollt \\
\hline fie dürfen & fömnen & mögen & muijien & follen & mollen \\
\hline Sie dürfen & fönnen & mögen & müffien & jollent & ivollen \\
\hline \multicolumn{6}{|c|}{ PAST } \\
\hline durfte & fonnte & modste & mú̃te & jollte & mollte \\
\hline
\end{tabular}

\section{Perfect}

idf habe gedurft (gefonnt, gemodft, gemunt, gejollt, gemollt)

But, iaf) habe gehen bürfen (mögen, etc.)

\section{Pleperfect}

ich) hatte gedurit (gefonnt, gemod)t, gemu śt, gejollt, gewollt)

But, idf hatte gehen bürfen (mögen, etc.)

\section{Fitcre}

id) werbe dürfen (fönnen, mögen, müffen, follen, wollen)

Futcre Perfect

idf werbe gedurft (gefonnt, gemod)t, gemuß̄t, gejollt, gemollt) haben But, idf werbe haben gehen bürfen (mögen, etc.)

\section{Subjunctive}

\begin{tabular}{|c|c|c|c|c|c|}
\hline \multirow{2}{*}{ idf) bürfe } & \multicolumn{4}{|c|}{ Present } & \multirow[b]{2}{*}{ molle } \\
\hline & tönne & möge & miifie & jolle & \\
\hline \multicolumn{6}{|c|}{ PAST } \\
\hline i(f) bürfte & fönnte & mö(f)te & muïßzte & jollte & mollte \\
\hline
\end{tabular}




\section{Subjunctive}

Perfect

idi) habe gedurft (gefonnt, gemodt, gemußst, gejollt, gewollt)

But, id) habe gehen bürfen (mögen, etc.)

\section{Pluperfect}

id) hätte gedurft (gefonnt, gemodjt, gemußist, gejollt, gemollt)

But, id̆ bätte gehen bürfen (mögen, etc.)

\section{Future}

id) werbe bürfen (fönnen, mögen, müffen, follen, wollen)

\section{Future Perfect}

idi) merbe gedurit (gefonnt, gemod)t, gemuít, gejoflt, gemollt) haben But, id merbe haben gehen dürfen (mögen, etc.)

\section{Conditional \\ Present}

id) mürde dürfen (fönnen, mögen, müffen, follen, wollen)

\section{Perfect}

id) würbe gedurft (gefonnt, gemod)t, gemuist, gejollt, gewollt) haben But, id) würbe baben gehen bürfen (mögen, etc.)

\section{B. Strong Verbs arranged in Classes.}

For the convenience of the learner strong verbs may be divided into classes, according to their Ablaut (change of root-vowel).

\section{FIRST CLASS OF STRONG VERBS}

First Subdivision

$$
\text { Vowels- } \mathfrak{i} ; \mathfrak{a}, \mathfrak{u}
$$

Infinitive Past Past Part. Infinitive Past Past Part.

cibinden band gebunden oringen brang gebrungen

dinden fand gefunden

gelingen gelang gelungen

flingen flang geflungen

ringen rang gerungen

jd)lingen jojlang gejolungen

fajminden fdrwand gejulwumben fdiningen f(d)ang gefolmungen

fingen fang gejungen

finfen janf gejunfen

ipringen fprang geiprungen

finfen jtanf gejtunfen

trinfen tranf getrunfen

winden wand getwunden

zwingen zwang gezmungen 
Second Subdivision

Vowels - e (i); a, o

\begin{tabular}{|c|c|c|c|c|c|}
\hline INFINITIVE & Past & PASt PaRt. & INFinitive & Past & Past Part. \\
\hline befehlen & befahl & befohlen & rinnen & rann & geronnen \\
\hline beginnen & begann & begonnen & fdiclten & f(f)alt & gefdolten \\
\hline & barg & geborgen & f(d)immen & f(d)ramm & vomm \\
\hline beriten & barit & geboriten & jinnen & fann & gefonnent \\
\hline bredien & bract) & gebrodjert & ipinnen & fpann & geiponnen \\
\hline empfehlen & empfahl & empiohlen & ipredien & (prady & geiprodyen \\
\hline erfdoreden & eridfraf & erjidrodfen & itecten & itad) & gefitodien \\
\hline gebären & gebar & geboren & itchlen & $\mathfrak{i t a h \mathfrak { l }}$ & geftohlen \\
\hline gelten & galt & gegolten & fterben & ¡tarb & geitorben \\
\hline eroinnen & getwann & getwonnen & treffen & traf & getrofien \\
\hline$r f_{0 n}$ & half & geholfen & verberben & berbarb & verborben \\
\hline men & fam & gefommen & werben & warb & getworben \\
\hline & nahm & genommen & werfen & marf & gemorfen \\
\hline
\end{tabular}

Third Subdivision. A

Voweis - ie; o, o

Infinitine Past Past Part. Infinitive Past Past Part.

\begin{tabular}{|c|c|c|c|c|c|}
\hline biegen & $\mathfrak{b o g}$ & gebogen & 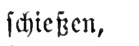 & $\mathfrak{f}(\mathfrak{)}) \mathfrak{B}_{\mathfrak{B}}$ & gefdoffen \\
\hline bicten & bot & geboten & f(d)lieben & (f) $(\mathfrak{C})(0 \tilde{B}$ & gefdidofien \\
\hline fliegen & flog & geflogen & fieden & fott & gcjotten \\
\hline flichen & floh & gefloben & fprię̧en & iprō̄ & elproll \\
\hline flieben & fló & geflofien & fticben & ftob & geitoben \\
\hline frieren & fror & gefroren & tricfen & troff & getrofien \\
\hline genief̧en & geno & genofien & verbriepen & berorofi & veroroif \\
\hline giēen & $\mathrm{g} 0 \overline{\mathfrak{B}}$ & gegoffen & verlieren & verlor & berloren \\
\hline fried)en & frod) & gefrodicn & wiegen & $\operatorname{mog}$ & gerooger \\
\hline ried)en & rod) & gerodjen & ziehen & $z 0 g$ & gezogen \\
\hline
\end{tabular}

juieben jajob gefdoben

Third Subdivision. B

$$
\text { Vowels-e, } \mathfrak{i}(\ddot{\mathfrak{a}}, \mathfrak{a} \boldsymbol{u}, \ddot{\mathfrak{b}}, \mathfrak{i}, \mathfrak{a}) ; \mathfrak{0}, \mathfrak{v}
$$

Infinitive Past Past Part. Infinitive Past

Past Part.

\begin{tabular}{|c|c|c|c|c|c|}
\hline $\begin{array}{l}\text { betwegen } \\
\text { brefduen } \\
\text { fedften } \\
\text { flect)ten } \\
\text { gären } \\
\text { glimmen }\end{array}$ & $\begin{array}{l}\text { betoog } \\
\text { orofid) } \\
\text { fodft } \\
\text { flodft } \\
\text { gor } \\
\text { glomm }\end{array}$ & $\begin{array}{l}\text { bewogen } \\
\text { gebrof(d)en } \\
\text { geforften } \\
\text { geflodften } \\
\text { gegoren } \\
\text { geglommen }\end{array}$ & $\begin{array}{l}\text { heben } \\
\text { flimmen } \\
\text { füren } \\
\text { löidfent } \\
\text { lügen } \\
\text { melfen }\end{array}$ & $\begin{array}{l}\text { bob } \\
\text { flomm } \\
\text { for } \\
\text { lofid) } \\
\text { log } \\
\text { molf }\end{array}$ & $\begin{array}{l}\text { gehoben } \\
\text { geflommen } \\
\text { geforen } \\
\text { geloidien } \\
\text { gelogen } \\
\text { gemolfen }\end{array}$ \\
\hline
\end{tabular}




\begin{tabular}{|c|c|c|c|c|c|}
\hline pflegen & pflog & gepflogen & f(f)nauben & f(f)nob & gefdinoben \\
\hline & quoll & gequollen & (d)rauben & (d)rob & efdroben \\
\hline aul & foff & gefoffen & & & \\
\hline aug & log & $g c \mid 0 g$ & ören & f(d) $n$ & \\
\hline & (d)oll & geidiollen & trügen & tro & getr \\
\hline & finor & gejdoren & & & \\
\hline d) $\mathrm{mel}_{3} \mathrm{en}$ & (f) $\mathrm{mol}_{3}$ & geid)molzen & miegen & $\operatorname{mog}$ & getoogen \\
\hline
\end{tabular}

Fourth Subdivision

Vowels - $\mathfrak{c}, \mathfrak{i} ; \mathfrak{a}, \mathfrak{c}$

\begin{tabular}{|c|c|c|c|c|c|}
\hline INFINITIV & Past & Past Part. & INFINITIVE & PAST & Past Part \\
\hline bitten & bat & gebeten & liegen & lag & gelegen \\
\hline effen & $\mathfrak{a} \mathfrak{B}$ & gegefien & mefien & $\operatorname{ma} \mathfrak{B}$ & gemeflen \\
\hline freffen & fra $\bar{B}$ & gefreffen & fehen & $\mathfrak{j a \mathfrak { h }}$ & gejehen \\
\hline geben & $g a b$ & gegeben & fitzen & $\mathfrak{f a \hat { z }}$ & gefelien \\
\hline genelen & genaz & genejen & treten & trat & getreten \\
\hline gef(d)ehen & geidjah & gefdeken & bergeffen & vergafí & vergeflen \\
\hline lefen & $\mathfrak{l a} \mathfrak{z}$ & gelejen & & & \\
\hline
\end{tabular}

\title{
SECOND CLASS OF STRONG VERBS
}

\author{
First Subdivision
}

Vowels- $\mathbf{e} ;$; $\mathbf{i}$ i

\begin{tabular}{|c|c|c|c|c|c|}
\hline INFINITIVE & Past & Past Part. & INFINITIVE & Past & Past Part \\
\hline befleif̧en & beflizis & befliffen (fidf) & reiten & ritt & geritten \\
\hline beizen & & gebiffen & f(d)leidyen & f(d)lidf & gefd)liden \\
\hline erbleiden & erblid) & erbliduen & fdrleifen & fdifliff & gefdrlifien \\
\hline gleichen & gli(f) & geglicken & f́lleifen & $\{\mathfrak{\alpha}) \mathfrak{l} \overline{\mathfrak{B}}$ & gef(d)lifien \\
\hline gleiten & glitt & geglitten & (đ)meízеn & fămi & geidfmiffen \\
\hline greifen & griff & gegriffen & fanneiden & idfnitt & geidnitten \\
\hline feifen & fiff & gefifien & fdreten & fdritt & gefdritten \\
\hline fneifen & eniff & getniffen & fpleif́nen & iplí̄ & geipliffen \\
\hline leiben & litt & gelitten & ftreiden & (trid) & gejtridjen \\
\hline pfeifen & pfiff & gepfiffen & itreiten & ftritt & geftritten \\
\hline reiźnen & rißs & gerifien & meidjen & mid) & gemidfen \\
\hline
\end{tabular}


Second Subdivision

Vowels-ei; ie, ie

Infinitive Past Past Part. Infinitive Past Past Part.

Ubleiben blieb geblieben fafreiben farieb gejarieben

gedeiken gebieh gebiehen fitreien f(f)rie gejurien

leiken lieh gelieben

meiden mied gemieben

preijen priez gepriejen

reiben rieb gerieben

folben fated geforieden

ideinen idjien geffienen

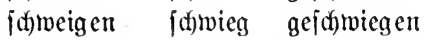

ipeien ipie geipien

jteigen jitieg gejtiegen

treiben trieb getrieben

verzeihen verziel) verziehen

weifen miez gerwiefen

THIRD CLASS OF STRONG VERBS

First Subdivision

Voweis-a, $(\mathfrak{c}, \mathfrak{c i}, \mathfrak{v}, \mathfrak{u})$; ie (i), $\mathfrak{a}$

Infinitice Past Past Part. Infinitive Past Past Part.

\begin{tabular}{|c|c|c|c|c|c|}
\hline blajen & bliez & geblajen & heižn & $\mathfrak{h}$ heb & geheiz̄en \\
\hline braten & briet & gebraten & Iaffen & lie $\overline{\mathfrak{B}}$ & gelaffen \\
\hline fallen & fiel & gefallen & laufen & lief & gelaufen \\
\hline fangen & fing & gefangen & raten & riet & geraten \\
\hline gehen & ging & gegangen & rufen & rief & gerufen \\
\hline halten & bielt & gehalten & f(d)lafen & f(t)lief & geid)lafen \\
\hline angen & bing & gehangen & ftónen & f́tié̉ & geitoźn \\
\hline batren & hieb & gehauen & & & \\
\hline
\end{tabular}

Second Subdivision

VoweIs $-\mathfrak{a}(\mathfrak{e}) ; \mathfrak{u}, \mathfrak{a}$

Infinitive Past Past Part Infintane Past Past Part.

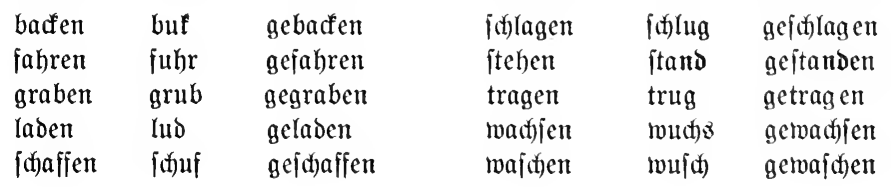




\section{ALPHABETICAL LIST OF STRONG AND IRREGULAR VERBS}

Strong verbs and weak verbs which show some irregularity of form. The $2 d$ and $3 \mathrm{~d}$ person singular of the present indicative are given only when these forms differ from the regular conjugation of this tense; for the same reason the first person is given with a few verbs. Intransitive verbs which take fein as auxiliary in compound tenses are indicated by iift in the past participle; intransitive verbs of motion which take haben when expressing rather the action, but fein when expressing rather the idea of transition from one place to another, are marked $\mathfrak{f}$. and $\mathfrak{h}$. in the infinitive. Meanings printed in Roman are cognates.

INFINITIVE

baden, bake

befehlen, command

befleižen, apply

beginnen, begin

beižen, bite

bergen, hide

berjten, burst

bewegen, induce

biegen, bend

bieten, offer

binden, bind

bitten, ask

$\mathfrak{b l a j e n , ~ b l o w ~}$

bleiben, remain

bleid)en, bleach

braten, roast

brecten, break

brennen, burn

bringen, bring

Denfen, think

bingen, hire

breidten, thresh

bringen, press

Dürfen, may

empfehlen, recommend

eijen, eat

fahren, f. and h. go, ride

fallen, fall

fangen, catch

fed)ten, fight
PRES. IND.

bäcfít, bädf́t

befieblit, befiehlt befahl

befleiß̄t, berleiß̧t

beiß̄t, beiß̄t

birgit, birgt

birit, birit

blạ̈t, bläjt

....

$\ldots$

brätít, brät

bridjit, bridit
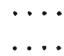

$\ldots$

orifat, orifat

Pr. Darf, barfit,

Darf; bürfen, etc.

see bejehlen

$i$ ist, $i$ ist

fäbrit, fährt

fällfit, fällt

fäng it, fäng t

fiditit, fidit
PAST

buf

beflipi

begann

bijiz

barg

barit

berogg

bog

bot

band

bat

bliez

blieb

blich

briet

bradi

brannte

bradte

Dadite

Dang

oroin

brang

Durite

$\mathfrak{a} \mathfrak{k}$

fuhr

fiel

fing

fodt
PAST PART. gebacfen bejohlen beflitien begonnen gebifien geborgen ijt geboriten bewogen gebogen geboten gebunden gebeten geblajen ift geblicben geblid)en gebraten gebroden gebrannt gebradyt gedadt gedungen gebrojden ijt gebrungen gedurit gegefĩen ift gefahren iit gefallen gefangen gefor)ten 
finoen, find

fled)ten, braid

fliegen, $\mathfrak{f}$. and $\mathfrak{h}$., fly

flichen, flee

fliekzen, $\mathfrak{f}$. and $\mathfrak{h}$., flow

freifien, eat

frieren, f. and $\mathfrak{h}$., freeze

gären, $\mathfrak{f}$. and $\mathfrak{h}$., ferment

gebären, bear

geben, give

gedeihen, thrive

gehen, $\{$, and $\mathfrak{h}$., go

gelingen, succeed

gelten, be worth

genejen, get well

geniezen, enjoy

geĩd) $\mathfrak{e} \mathfrak{e n}$, happen

getwinnen, win

gie $\tilde{z}_{\mathfrak{z}} \mathfrak{e n}$, pour

gleidyen, be like

gleikzen, glitter

gleiten, $\mathfrak{f}$. and $\mathfrak{h}$., glide

glimmen, gleam

graben, dig

greifen, seize

$\mathfrak{h a b e n , ~ h a v e ~}$

halten, hold

hangen, hang

hauen, hew

heben, lift

heiken, be named

helfen, help

fennen, know

flicben, cleave

flimmen, f. and $\mathfrak{h}$., climb

flingen, sound

fneifen, pinch

fommen, come

fönnen, can flichtit, flic(f)t

fließst, fließst

frízt, friß̄t

gebierit, gebiert

gibit, gibt

giltit, gilt

gej(fieht

$\mathfrak{g}$ räbit, gräbt

hait, hat

hältịt, hält

bäng it, hängt

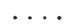

$\ldots$

heist, heint

hillfit, bilfft

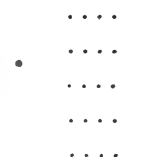

Pr. fann, fannit,

fann; fönnen, etc. fand

gefiunden

flocht

flog

floh)

frôz

fra

fror

gor

$\mathfrak{g e b a r}$

$\mathfrak{g} \mathfrak{a} \mathfrak{b}$

gebiel

ging

gelang

galt

genas

genoiz

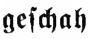

gewantt

$\mathfrak{g o \mathfrak { z }}$

glid)

gli $\mathrm{i}$ ?

glitt

glomm

grub

griï

hatte

hiclt

hing

$\mathfrak{h i c b}$

$\mathfrak{h o b}$ and

hub

hiciz

$\mathfrak{h a l \mathfrak { j }}$

fannte,

flob

flomm

flang

friii

$\mathfrak{f a m}$

fonnte gefloditen

iit gerflogen

ijt gefflohen

ijt gerlofien

gejureifen

gejruren

ijt geguren

geboren

gegeben

ijt gedieken

ijt gegangen

ijit gelungen

gegolten

ijt genejen

genolien

ijt $\mathfrak{g e j}$ de $\mathfrak{e}$ en

gewonten

gegolīen

geglidjen

geglififen

ijt $\mathfrak{g e g l i t t e n}$

geglommen

$\mathfrak{g e g r a b e n}$

gegrififen

$\mathfrak{g c h a b t}$

$\mathfrak{g e h a l t e n}$

gefiangen

gefauen

$\mathfrak{g e h o b e n}$

geheip̈en

$\mathfrak{g e h o l j e n}$

gefannt

gefloben

ijt geflommen

geflungen

gefnifïen

ijt gefommen

gefount 
fried)en, $\mathfrak{f}$, and $\mathfrak{h}$., creep

fürcin, choose

laben, load

Iaijen, let

$\mathfrak{l a} u \tilde{f} \mathfrak{c}, \mathfrak{f}$. and $\mathfrak{h}$., run

leiben, suffer

Icil)en, lend

Iejen, read

liegen, lie

lüjd)en, go out (fire)

lügcn, lie

meiben, shun

melfen, milk

meilin, measure

mizlzingen, f., see gelingen

mögen, may

miiijen, must

nehmen, take

nenuen, name

picifen, whistle

pflegen, cherish

preijen, praise

quellen, gush out

raten, advise

reiben, rub

reizizen, tear

reiten, f. and $\mathfrak{h}$., ride

rennen, $\{$. and $\mathfrak{h}$., run

richen, smell

ringen, wrestle

rinnen, flow

rufen, call

jaufen, drink

jautgen, suck

(đ)a fïen, create

id)allen, sound

ideiben, part

id)einen, seem

idielten, scold läbjt, läbt

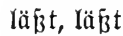

\äufít, läuft

lieit, lieit

lif(f)t, lifict)t

...

milfit, millet

mißst, mint frŭdh) ijit gefrŏd)en

for

Pr. mag, magit, mod)te, mag; mögen, etc.

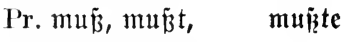

muñ ; müfien, etc

nimmit, nimmt

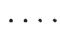

$\cdots$

preift, preijt

quillit, quirlt

rätït, rät

fäufịt, fäuft
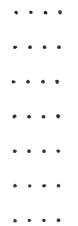

.
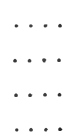

$\ldots$

jafiltit, jujilt
IUd

licis

lief

litt

lich

$\mathfrak{l a \mathfrak { s }}$

lag

lojd)

$\mathfrak{l o g}$

micd

molf

$\mathfrak{m} \bar{a} \dot{z}$

geforen

gelaben

gelailien

ijt gelaufen

gelitten

gelieken

gelejen

gelegen

ijt geloidien

gelogen

gemieden

gemolfen

gemeîen

gemo(f)t

gemนй

nal)m

nannte

pifiï

$\mathfrak{p f l o g}$

pries

quoll

riet

ricb

riiz

ritt

rannte

rod)

$\mathfrak{r a n g}$

rann

ricf

ioif

iog

โđ)น์

id)oll

jufied

jaien

id)alt genommen

genanut

gepfifien

gepflogen

gepriejen

ijt gequollen

geraten

gerieben

geriilien

ijt geritten

iift gerannt

gerodien

gerungen

ift geronnen

gerufen

gejoifen

gejogent

geid)a

geïd)ollen

geidieden

geidienen

gejd)olten 
id)cren, shear

jdiebent, shove

idfięzen, shoot

idjinden, flay

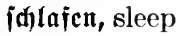

(d) lagen, strike

(d) $(\mathfrak{e i d}) \mathfrak{e n}$, f. and $\mathfrak{h}$., creep

(d) leifen, whet, grind

(d)I $\mathfrak{c} i \tilde{z}_{\mathfrak{e n}} \mathfrak{n}$, slit

id) licizen, shut

id)lingen, sling

(đ)meipen, dash

(d) $\mathfrak{m e l} \mathfrak{z} \mathfrak{e n}$, f. and $\mathfrak{h}$., melt

idneiben, cut

id)rauben, screw

(d)reffen, be afraid

id)reiben, write

(d)reicn, cry

id)reiten, stride

fdimeigen, be silent

id)wellen, swell

id)wimmen, f. and h., swim

(d) winben, vanish

id)wingen, swing

(d) wören, swear

iehen, see

ientern, send

fieden, boil

fingen, sing

jinfen, sink

finnen, think

jitsen, sit

joflen, shall

Ipeien, spit

ipinnen, spin

iplcižcn, split

ipredien, speak fdierit, fdutert

(d)ießst, f(f)icist

fdd)läfft, fod)läft

fduläg ft, fđd)läg t

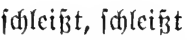

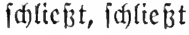

fd)mil ${ }_{3}$ ft, fdemil ${ }_{3} t$

f(d)ricfit, fdyrifft

.

fdrwillit, fdyillt

…

fiebit, fiebt

fitzit, fitzt

Pr. foll, follft, foll; follen, etc.

fpleißjt, fpleiß̧

fpridsit, fprid)t jdjor

idiob

iđgu?

(d) und

(d) lici

idflug

idflidi)

geidjuren

geidjoben

geid)viīen

gejdunben

geid)la $\mathfrak{a} \mathfrak{c}$

$\mathfrak{g c j d} l \mathfrak{l a g e n}$

ift gejuliduen

id)liii

id) (iiz

geiddlifïen

(d)loi?

jot)lantg

id) miti?

(d) $\mathfrak{m t o l}_{\mathfrak{j}}$

id) nitt

jd)rub

id)rat

jaricb

id)ric

idfritt

idfoicg

id)woll

geid)liijen

geichloilien

gejdlungen

geichmilïen

$\mathfrak{g c} \mathfrak{i}(\mathfrak{)}) \mathfrak{m o l} \mathfrak{z} \mathfrak{e n}$

id)twamm ift gejd)wommen

(d)want ift geidimuntoen

idfwang gej(t)imungen

id)wor

ing

iandte

jott

jang

janf

ianu

iais

jullte

ipic

ipatu

ipliz

iprad) geidnnitten

geidgroben

ift crid)roden

gejd)ricbent

gejd)rien

ift gejdritten

geid) wiegen

ijt gejdimollen

gejd)woren

geiclyen

gejandt

gejotten

gejungen

ift geiunten

geicinen

gejullt

geipicn

geiponnen

geiplifien

geiprod)en gejonnen 
ipricizen, sprout

ipringen, $\mathfrak{f}$. and $\mathfrak{h}$.,

spring

ited)en, prick

iteclyen, stand

itchlen, steal

itcigen, f. and $\mathfrak{h} .$, mount

iterben, die

fticben, scatter

finfen, stink

jtoken, push

itreidyen, stroke

itreiten, quarrel, argue.

tunt, do

tragen, carry

tref̃en, hit

treiben, drive

treten, $\mathfrak{f}$. and $\mathfrak{h}$., step, kick

triejen, drip

trinfen, drink

trïgen, cheat

verberben, spoil

verbrięzen, vex

vergeffen, forget

verlieren, lose

wadjien, grow

wajacn, wash

webcn, weave

weid)en, yield

weijen, show

wenden, turn

werben, sue

werden, become

werfen, throw

wiegen, weigh

winben, wind

wifien, know fprieß̄t, fprießst

fticfjeft, fticist

ftiehlit, ftiehlt

jtirbjt, ftirbt

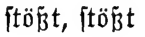

Pr. tue, tult, tut,

tum, etc.

träg jt, träg $t$

triffift, trifft

trittit, tritt

\begin{tabular}{|c|}
\hline $\begin{array}{c}\ldots \\
\ldots \\
\text { verbirbit, verdirbt } \\
\text { verbrie } \bar{\beta} t, \text { verbrie } \bar{t} t \\
\text { vergi } i \bar{b} t \text {, vergi } \bar{\beta} t\end{array}$ \\
\hline 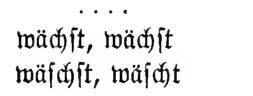 \\
\hline$\cdots$ \\
\hline \\
\hline
\end{tabular}

mirbit, wirbt

wirit, miro

mirfit, mirft

....

Pr. meī̄, weiß̄t, weiß; wifjen, etc. fproé ift geiprofien

jprang ijt gejprungen

itad)

itand

itathl

fitieg

itarb

itob

itant

jticis

itridi)

itritt

tat

trug

$\operatorname{tra} \mathfrak{j}$

tricb

trat

troif

tranf

trog

verbarb

verbrok

verga

verlor

wuth

wald

$\mathfrak{w o b}$

widh

ries

wandte

warb

wurbe.

and ward

warf

wog

wand

wurizte geitodyen

geitanden

geitof)len

ift geitiegen

iit geitorben

ijt geitoben

geítunfen

geitopen

gejtridaen

geitritten

getan

getragen

getrofien

getrieben

ijt getreten

getrofifen

getrunfen

getrogen

verborben

verbrofien

vergefifen

verloren

getwajden

gewoben

ift gervidyen

gerviejen

getwandt

getworben

ift geworben

worben

geworfen

gewogen

getwunden

geroukt ijt gemadjen 
wollen, will

will, willit, will; wollte

gewollt

mollen, etc.

zeihen, accuse

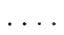

zieh

zichen, f. and h., tr., draw;

$\mathfrak{z o g}^{\mathfrak{o g}}$

geziehen

intr., move

zroingen, force

zwang

gezmungen

\section{VERBS GOVERNING THE GENITIVE}

(1) The following verbs may take a genitive as object. But in modern German most of them use some other construction (as given in brackets). The genitive occurs mostly only in poetry or in dignified writing as: ich bebarf bes Gerbes, I need the money; er gedentt unjer, he thinks of us.

\begin{tabular}{|c|c|}
\hline 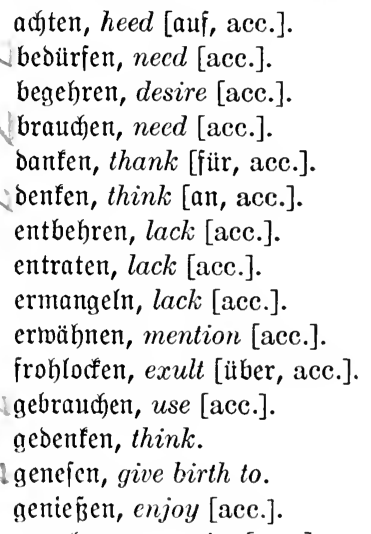 & 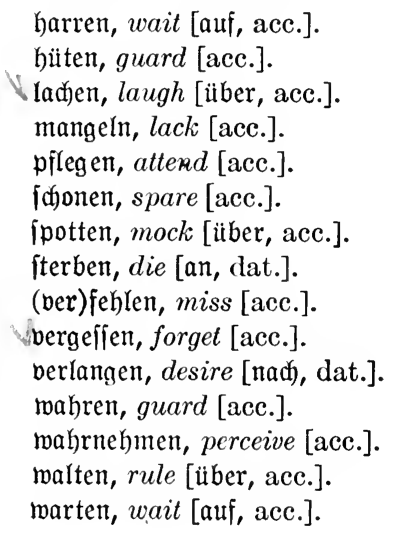 \\
\hline
\end{tabular}

gewahren, perceive [acc.].

(2) The following verbs take a direct object of the person in the accusative; a serondary object (of the thing) stands in the genitive, expressed usually in English by "of" or "from", as: er flagte ihn bes Diebitahls an, he accused him of theft.

anflagen, to accuse

bej(d)uldigen, to accuse

freifpredsen, to acquit

überführen, co convict

erinnern, to remind

mahnen, to warn berauben, to rob

entheben, to relieve

entledigen, to relieve

entlajien, to dismiss

verjidjern, to assure

würbigen, to deem worthy 
(3) Many reflexive verbs take the secontary object in the genitive, as: er bebiute jidg eines Stodtes, he made use of a stick.

(iid) anma izen, to claim

fid) bebienen, to make use of

(id) bemäd)tigen, to get possession of (idd) rühmen, to boast fid) befinnen, to bethink oneself

(itd) erbarmen, to take pity

and many others.

\section{E. VERBS GOVERNING THE DATIVE}

The following verbs govern the dative:

\begin{tabular}{|c|c|c|}
\hline $\begin{array}{l}\text { ähneln, resemble } \\
\text { antworten, answer } \\
\text { begegnen, meet } \\
\text { behagen, please } \\
\text { befommen, befit } \\
\text { danfen, thank } \\
\text { dienen, serve } \\
\text { orohen, threaten } \\
\text { bünfen, seem } \\
\text { erliegen, succumb } \\
\text { (er)f(n)einen, appear } \\
\text { feblen, fail } \\
\text { flutijen, curse }\end{array}$ & $\begin{array}{l}\text { folgen, follow } \\
\text { frommen, benefit } \\
\text { gebühren, befit } \\
\text { gefallen, please } \\
\text { gehören, belong } \\
\text { gehordfen, obey } \\
\text { genügen, suffice } \\
\text { gefdueben, happen } \\
\text { (ge)zicmen, become } \\
\text { glauben, believe } \\
\text { glcidjen, resemble } \\
\text { grollen, be angry } \\
\text { helfen, help }\end{array}$ & $\begin{array}{l}\text { huldigen, pay homage } \\
\text { mangeln, be lacking } \\
\text { nahen, approach } \\
\text { nützen, benefit } \\
\text { palfen, fit } \\
\text { f(u)aden, injure } \\
\text { f(f)meidheln, flatter } \\
\text { trotzen, defy } \\
\text { (ver)trauen, trust } \\
\text { weid)en, yield } \\
\text { wehren, defend } \\
\text { zürnen, be angry }\end{array}$ \\
\hline
\end{tabular}

Thus: er antwortete $\mathrm{i} \mathfrak{h r}$, he answered her; jie banft $\mathrm{i} h \mathrm{~m}$, she thanks him.

\section{F. RULES FOR THE DETERMINATION OF GENDER OF SOME GERMAN NOUNS}

(Concerning natural gender in German, see Lesson II. 2 (3).

I. The following are masculine:

a. Names of days, months, seasons, points of the compass: ber Mon= tag, ber Mai, ber Sommer, ber Eiiden.

$b$. Most monosyllabic nouns formed from a verbal root, without suffix: Der Fang, the catch; Der $\widetilde{E}(\mathfrak{1}) \mathfrak{\beta}$, the shot; Der Bund, the alliance.

c. Nouns ending in idf, ig, ling: Der Ieppid), the carpet; Der Piennig, the penny; der Edfillitig, the shilling.

d. Nouns in $\mathfrak{c r}$, with the exception of infinitives used as nouns: ber (5arten, the garden; Der Raden, the shop; Der Boden, the bottom, ground.

II. The following are feminine:

a. Most nouns ending in $\mathfrak{c}$, excepting those that denote male beings 
and those words with the prefix (Gc=: Die Etunde, the hour; Dic 巨omme, the sun; bie Dintc, the ink; bie $\subseteq$ tra $\mathfrak{B} c$, the street.

b. All nouns ending in ci, hcit, feit, icha ft, ung, if, ion, tät: bie Bädferei, the bakery; bie Freibeit, liberty; Dic Söplidftcit, politeness; Dic Randidgaft, the landscape; die Ïbung, the exercise; Dic Mufif', the music; Dic Mation', the nation; die Majeität', the majesty.

$c$. The names of German rivers (excepting Dcr $\Re$ hcin, Der Main, Dcr Necfar): Die Donau, the Danube; Die Elbe; bie Mcier.

d. Most abstract nouns: Die Beduld, patience; Die Iugend, virtue; die Эugend, youth. (Abstract nouns in German, unlike the English, take the article.)

III. The following are neuter:

a. Infinitives used as nouns: Daz (jchen, the walking; Daz Iaufen, the running; ๖aß Stehel, the standing.

b. Most nouns with the prefix (bic: Das Bcbirge, the mountains; daz (Sefityt, the face; (but bic (jejabr, the danger).

c. Diminutives in d)en and $\mathfrak{l}$ cin: Das Mäbd)en, the girl; bas Fräulein,

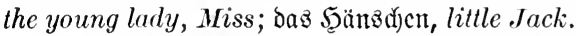

d. Names of cities and most names of countries (excepting bic $\mathbb{E} d$ f)tciz Switzerland; bie Türfei, Turkey): ఏав Berlin, Dą Deuti(f)(and.

$e$. Names of animals which designate the species or the young with-

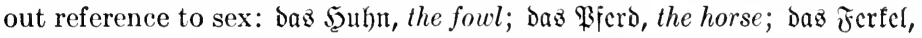
the little pig; Das $\Omega a l b$, the calf; Das $\mathfrak{R} a m m$, the lamb.

\section{G. WORD FORMATION}

\section{Nouns derived from Verbs}

1. The suffix $-\mathfrak{c r}$ (English $-c r$ ) is used to form nouns denoting an agent or instrument. They are all masculine:

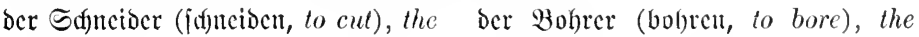
tailor. gimlet.

ber Bäffer (bacfen, to bake), the Der Beiger (jeiucn, to show), the baker. ber Rchrer (lehren, to teach), the

2. The suffix-cl is used to form noums denoting an instrument. They are mostly masculine:

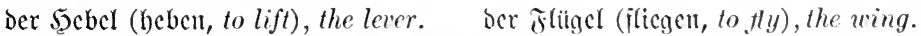

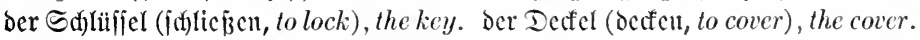

But, Dic Gabel (geben, to give) the fork. 
3. The suffix $-n i z$ is used to form abstract nouns from verbs:

bie Erlaubniz (erlauben, to allow), the permission.

die Renntniz (fennen, to know), the knowledge.

daz Zeugniz (zeugen, to bear witness), the testimonial, report.

4. The suffix -ung is used for forming a large number of nouns from verbs, mostly abstracts. All are feminine:

bie Bemerfung (bemerfen, to remark), the remark.

bie İbung (itben, to practice), the practice, exercise.

bie Stellung (itellen, to place), the position.

5. The suffix $-\mathfrak{c n}$ forms masculine derivatives, such as:

Der Braben (graben, to dig), the ditch. Der Bifien (beißßen, to bite), the bit; $-\mathfrak{c n}$ is also the ending of the infinitive, which may be used as a noun, is always neuter and takes the definite article:

daz Singen, (the) singing.

daz $\mathfrak{A}$ rbeiten, working.

daz Racten, laughing.

daz ऽpređjen, talking.

daz ธafmeigen, being silent.

daz $\Re \mathfrak{A} u(\mathfrak{c})$ en, smoking.

6. Some nouns are simply the stems of verbs - usually of strong verbs - formed from one of the three principal parts of the verb or by ablaut. They are usually masculine:

ber Rat (raten, to advise), the coun- Der Band (binden, to bind), the volcil.

der Sitz (jitzen, to sit), the seat. Der Iranf (trinten, to drink), the drink. ume.

Der Bug (ziehen, to move, pull), the train, draft, feature, procession. daz $\mathfrak{b r a b}$ (graben, to dig), the grave.

\section{Nouns derived from Adjectives or Nouns}

A. Many nouns are derived from adjectives, or from other nouns, by means of suffixes:

1. - $\mathfrak{e}$ forms feminine abstracts from adjectives, modifying the rootvowel:

bie Ränge (Iang), the length.

die Brößze (groß̉), the size, greatness.

bie Şöhe (hod)), the height. bie (Sitte (gut), the goodness, kindness.

bie Sabuäde (iffwact)), the weakness. die Stärfe (itarf), the strength.

2. -cr forms, from nouns, masculine names, usually modifying the root-vowel: 
Der Engländer (England), the Eng- Der $\mathfrak{A}$ merifaner (ATmcrifä), the A merlishman.

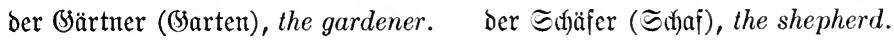

3. $-\mathfrak{e} \mathfrak{i}^{\prime},-\mathfrak{e r e i}$, forms feminine abstracts or collectives, from nouns (chiefly in er):

bie Bädferei (Bäcfer), the bakery. Die Fif therei (Fifdter), the fishery.

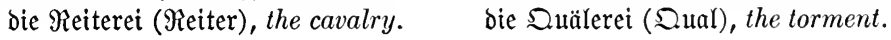

4. -ling, forms a few masculines from adjectives, or nouns:

Der Эüngling (jung), the youth. ber Früfling (früh), the spring.

ber Sünjtling (Gunft), the favorite. Der Flüd)tling (Flud t), the fugitive.

5. -tum (English -dom) forms from nouns, and from a few adjectives, collectives or abstracts, which are neuter, except Der Fieid)tum, riches,

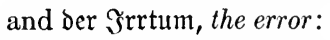

ঠав ภönigtum, the kingdom.

১ав Füritentum, the principality.
Daz Eigentum, (ei'gen, own), the property.

১aż $\mathfrak{A r}$ 'tertum, antiquity.

6. For nouns with the suffixes $-\mathfrak{d} \mathfrak{e n}$ and $-\mathfrak{l}$ ein see lesson XXVI, 78. For suffixes heit, feit, fadaft, in, see lesson XXIX, st.

B. Some nouns are derived by means of prefixes:

1. BSe-forms chiefly collectives, mostly neuters: daz (Hebirge (Berg), the mountain- die Gebrüber (Britber), pl., the range. ঠав Betrölf (Wolfe), the clouds. brothers.

bie Seffwifter (Stfweiter), pl., brothers and sisters.

also from verbs, as: baz (jebet' (beten), the prayer.

2. $\mathfrak{M} i \mathfrak{i}^{2}-$ and $\mathfrak{u n}$ - have the same force as the English ' $m i s$ ' and ' $u n$ ': die Miffetat, the misdeed. ber Uniun, the nonsense. Der Mißß̧ braud, the misuse. ber Undanf, the unthankfulness.

3. The prefix $\mathfrak{u r}-$ expresses origin:

bie Uriacte, the cause.

ber $\mathfrak{U}$ rwald, the primeval forest. bie llrwelt, the primitive world.

ber Urgrojpater, the great-grandfather.

4. (Erz- is the same as the English 'arch'-: Der $\mathcal{E r}_{z}$ bif )of, the archbishop.

Der Erzengel, the archangel. 


\section{Derivation of Adjectives and Adverbs}

Many adjectives and adverbs are derived by means of suffixes:

1. - bar usually forms adjectives from verbs, with the sense of the English ending -able or ible:
Iesbar, legible.
hörbar, audible.
$\mathfrak{e} \mathfrak{B} \mathfrak{b} \mathfrak{a r}$, eatable.
trinfbar, drinkable.

2. $-\mathfrak{e n},-\mathfrak{c r n}$ forms adjectives denoting material:
golden, golden.
hölzern, wooden.
filbern, silver.
\{täh)lern, steel.

3. - $-\mathfrak{r}$ see lesson $\mathrm{XX}, 55, d$.

4. -ig forms many adjectives or adverbs from nouns, adjectives, adjective pronouns, adverbs and verbs:

walbig (Wald), woody. gütig, kind.

meinig, mine.

wolfig ( $\mathfrak{B o l f e})$, cloudy. böllig, complete. deinig, thine.

mäd)tig (Mad)t), mighty. hiejitg (hier), local. dortig, yonder.

gefällig (gefallen), obliging. übrig (über), remaining. vorig, former.

5. -ijd) (English -ish) denotes relating to, belonging to:

findifd), childish.

meibifd), womanish. berlinif(d), of Berlin.

himmliff(t), heavenly.

6. -lid) (English -like, -ly), usually with umlaut, denotes resemblance:

ältrlidy), oldish. männliđ, manly. möglidf), possible. neuli(f), recently. gelblidf), yellowish.

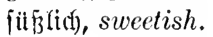
findli(f), childlike. wahrlidy, truly. füritli(f), princely. weiblic), womanly. fommerlid), like summer. gänz̧li(f), entirely.

7. -jam (English -some) forms adjectives or adverbs from nouns, verbs, etc:
einfan, lonely.
arbeitfam, industrious.
iparfam, saving.
furctifant, timid.

8. -haft forms a few adjectives or adverbs:

boßłhaft (böfe), malicious.

f(f)ülerhaft, school-boy like.

9. - -weije (-wise) forms adverbs from genitive forms: glïdflidjermeife, luckily. ınglücffiç)ermeife, unluckily.

möglidferweife, possibly. zufärligerweife, accidentally.

but also with uninfleeted prefix: ftüctmeife, piecemeal. 
10. The genitive ending $-\$$ may form adverbs from nouns (see lesson XLVIII, 17S), adjectives, or participles:

abends, in the evening. nad)ti, in the night. linfz, on the left. anfang 8 , in the beginning.

teili, partly.

eilendo, in haste.

The ending - $\mathfrak{c}$ ? 2 may also form adverbs:

fpätejtenz, at latest.

hödjitens, at the utmost.

11. -wärtz (-wards) forms adverbs as in English: aufmärtż, upwards.

oj̣twärtż, eastward.

Note. - As almost any qualifying adjective may be used as an adverb without change of form, there is no general adverb suffix like English -ly. 
236

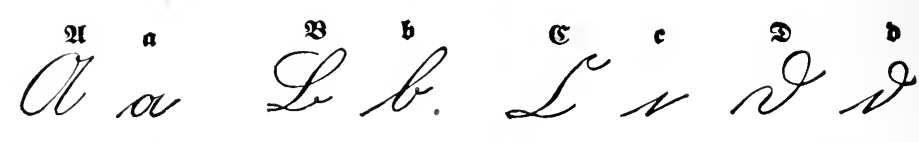

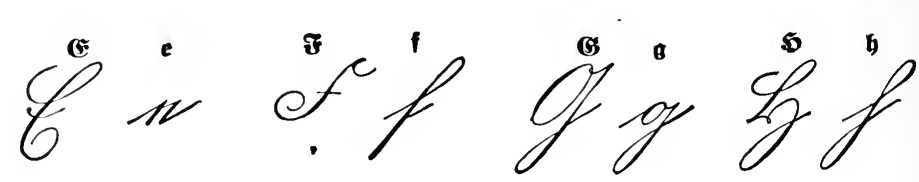

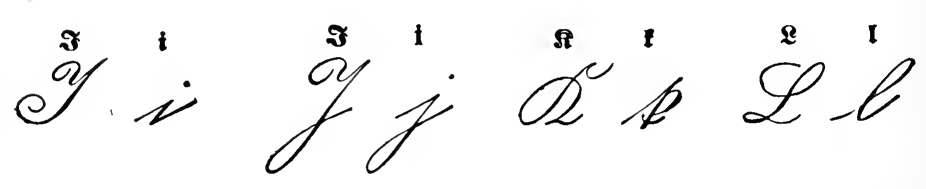

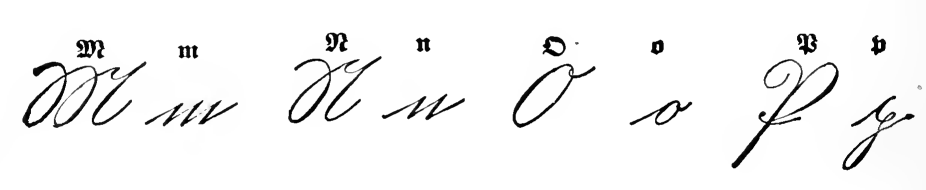

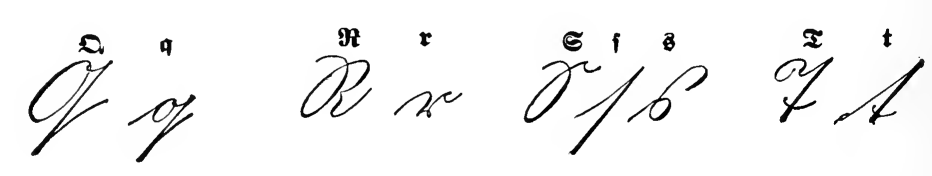

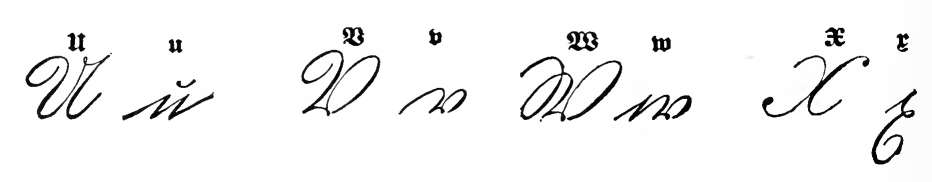

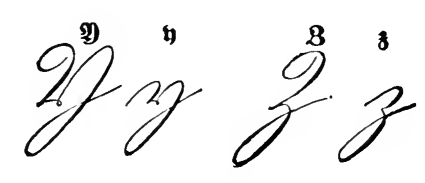


$\|^{\ddot{\mathfrak{i}}} \ddot{\mathbf{a}}$

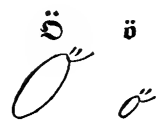

$\mathscr{V}^{\ddot{i i}} \ddot{\text { in }}$
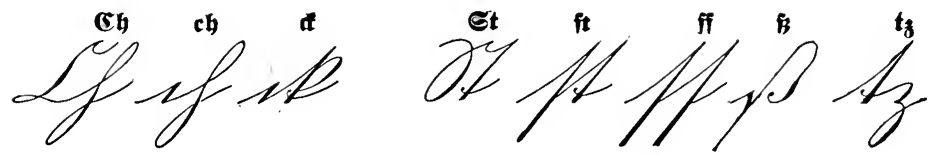

(Transcription of the letter on page 205)

\section{Lambing, Diflenluftrapro 21 23 An OOCowi 1912.}

Linber Oifmorttrus!

$$
\text { Domm Nis mis nims }
$$

znitig gnfifsinbow foiltrft, sops

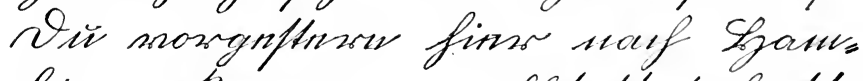
binrog tommum moalltrit, fo fiettr

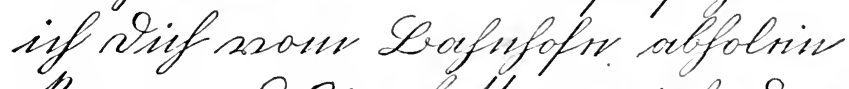
Poumm. Wroir fouttur ainf inw Fag zisfomum sambiringuev toumm. Wiv fättrft nin abor ssins sim zrsanzig Otiminew 


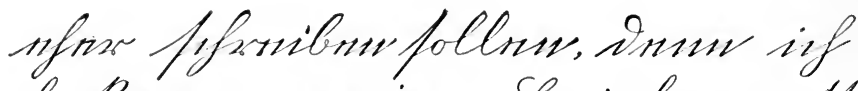

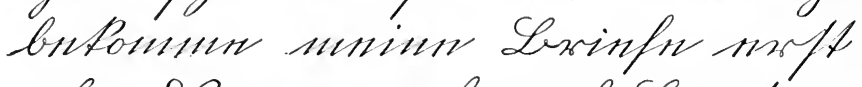

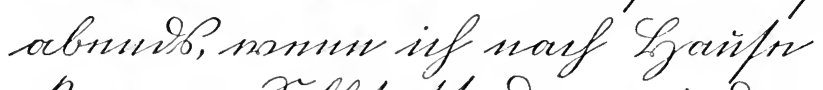
foumur. Dellfuft tiv moinim

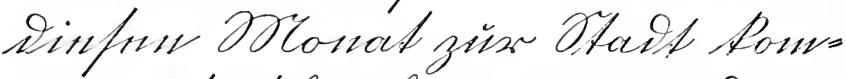

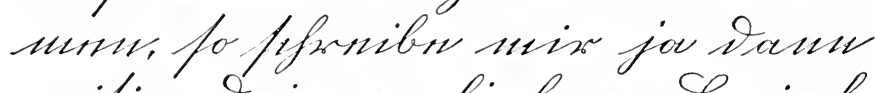
zmitig. Anmum limbruv Darinf

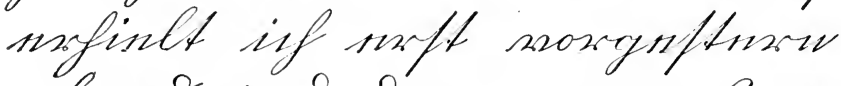

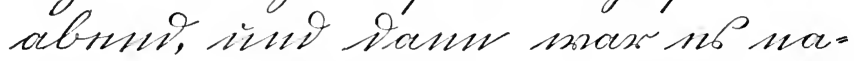

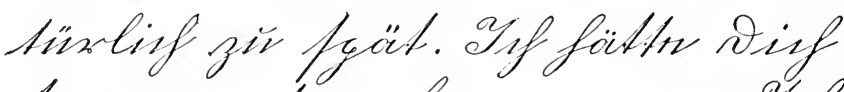

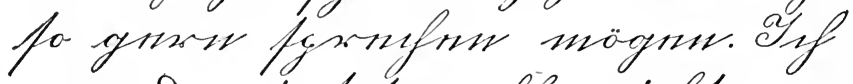
momsin jinty mofl minft now

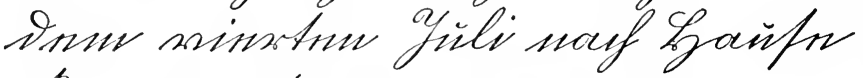
foumun foum inim misinsme

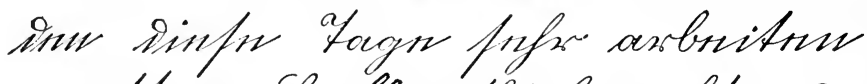

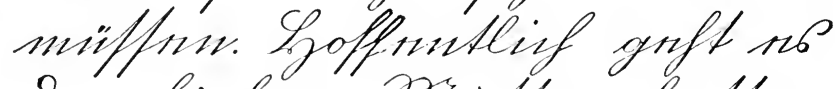

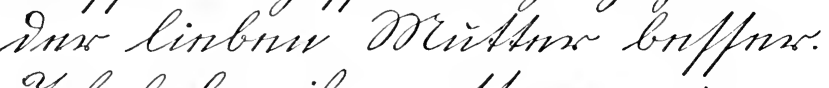
anf foubre ifor greftrom minum

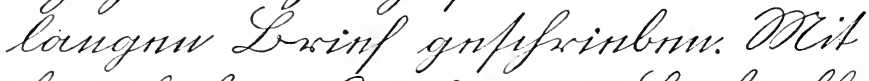

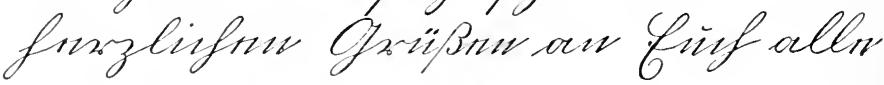

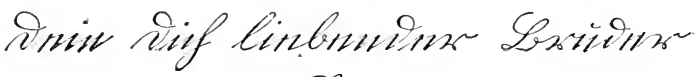
Gours? 


\section{VOCABULARIES}

\section{ABBREVIATIONS AND EXPLANATIONS}
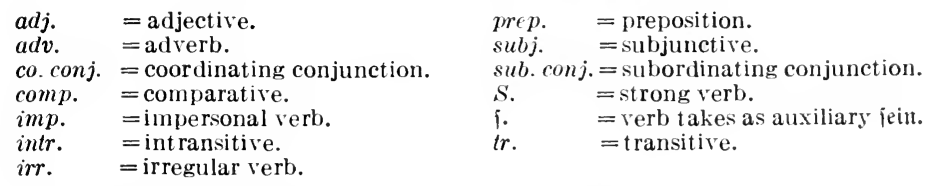

A dash (-) indicates the repetition of the title word. The genitive of nouns is indicated when it differs from the nominative, the plural is indicated whenever the

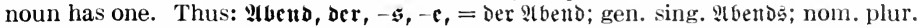
Ubenve. Separable compound verbs are indicated by the accent ('). Proper names with identical spelling in both languages have been omitted. For the inflection of adjective nouns, see $\S 61$. With adjectives, " indicates umlaut in comparison. Verbs are weak, unless otherwise indicated; those marked $S$. are strong; in the English-German vocabulary the principal parts of strong and ir regular verbs are given, also third person sing. when irregular. The meanings given are confined to those used in the grammar.

\section{$\mathfrak{A}$}

$\breve{\mathfrak{a} \mathfrak{b}}$, off, down.

$\mathfrak{a} \mathfrak{b}^{\prime}$ brennen, irr., f., to burn down. $\mathfrak{Y b e n b}$, ber, $-\mathfrak{z},-\mathfrak{e}$, evening; heute abent, this evening.

$\mathfrak{a b e r}$, co. conj., but, however.

$\mathfrak{a} \mathfrak{b}^{\prime}$ id)reiben, $S$., to copy.

$\mathfrak{A}$ bifid)t, bic, $-e n$, intention.

$\mathfrak{a} \mathfrak{b}$ 'it $\mathfrak{e r b e n ,} S .,\{$., to fade, die out.

$\mathfrak{a b}^{\prime} \mathfrak{w} \boldsymbol{c i j e n}, S$., to refuse.

$\breve{\mathfrak{a} d}$, oh, ah, alas.

ăd)t, eight.

Foler, Der, $-\bar{z},-$, eagle.

all, all; alles, everything.

allcin', co. conj., but, yet.

$\mathfrak{a l s}, a d v$., as, than; sub. conj., as, when; - ob, - wenn, as if.

$\mathfrak{a} \mathfrak{l}^{\prime} \mathfrak{j} \mathbf{0}$, therefore, so, thus.

$\mathfrak{a l t}$,

$\breve{\mathfrak{a}} \mathfrak{m}=\mathfrak{a n}$ bem.

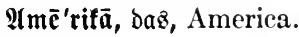

$\mathfrak{P} \mathfrak{m} \overline{\mathfrak{c}} \mathbf{r} \mathfrak{i} \overline{\mathfrak{a}}$ 'ner, ber, $-\bar{z},-$, the American.

ăı, prep. dat. and acc., at, on, near, against, to.

an'bellen, to bark at.

ander, other.

anders, differently.

$\mathfrak{a n}$ 'fangen, $S$., to commence, begin.

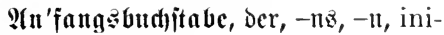
tial (letter).

ans $=$ all $D a z$.

auitatt', prep. gen., instead of.

au'itreid)en, $S$. , to paint .

ant'worten (irsep.), to answer.

$\mathfrak{Y}$ pfél, ber, $-\mathbb{z}, \pm$, apple.

$\mathfrak{P l p f e l b a u m , ~ D e r , ~}-\mathbb{z}, \pm \mathfrak{c}$, apple tree.

YIrbeit, bie, -en, work, labor.

ar'beiten (insep.), to work.

$\mathfrak{a r m}, \mu \mathfrak{e r}$, poor.

$\mathfrak{A} \mathfrak{r}_{\mathfrak{z}} \mathrm{t}, \mathrm{Der},-\mathfrak{e} \mathfrak{B},{ }^{\Perp} \mathfrak{e}$, physician. 
àtmen, to breathe.

aud), also.

auf, prep. dat. and acc., upon, on, onto.

$\mathfrak{a} \mathfrak{i} \tilde{\mathfrak{i}}, a d v$., open.

$\mathfrak{P} \mathfrak{u} \mathfrak{f}^{\prime} \mathfrak{g a b c}$, bie, $-\mathfrak{c n}$, lesson, exercise, task.

$\mathfrak{a} \mathfrak{f}^{\prime} \mathfrak{g e b e n}, S$, to give up, to check (a trunk).

$\mathfrak{a} u f^{\prime} \mathfrak{h e b e n}, S .$, to lift up.

auf'madien, to open.

auf'paifen, to pay attention.

$\mathfrak{a} \mathfrak{A}:=a u f$ bas.

Qtuffiaks, ber, -ez, "ee, essay, composition.

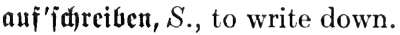

auf'ietzen, to put on.

auf'ipringen, $S .$, f., to jump up.

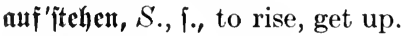

$\mathfrak{P} u \mathfrak{g c}, b a \mathfrak{z},-\mathfrak{z},-\mathfrak{n}$, eye.

aus, prep. dat., out of, from, of.

aus' $\mathfrak{g e b e n}, S$., to spend.

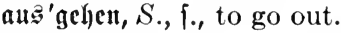

aus' 'rufen, $S$., to call out, exclaim.

aus'ichen, $S$., to look, appear.

$\mathfrak{a} \tilde{z}_{2} \mathfrak{c r}$, prep. dat., except, besides.

Afus'itellung, bie, -en, exhibition.

aus'verfaufen, to sell out.

aus'wcndig, externally, outside;

- wiffen, to know by heart.

aus'zichen, S., to take off, pull off.

\section{$\mathfrak{B}$}

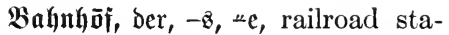
bald, soon, almost.

Bant, bie, "e, bench.

Bär, ber, -en, -en, bear.

bauen, to build.

Bauer, ber, $-\boldsymbol{z},-\mathfrak{n}$, farmer, peasant.

$\boldsymbol{B a u m}$, der, -ęa, $\Perp$ e, tree.

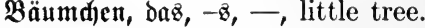
beei'len, fid - , to hasten, hurry. bejeh' 'len, $S$., to order, command. befin'ben, fid) -, S., to be. begēg'nen, f., to meet. begra' $\mathfrak{b e n}, S$., to bury. behal'ten, $S$., to keep. bei, prep. dat., by, near, at, with; - mir, about me, at my house. beide, both. beim $=$ bei bem.

Bein, baz, -ez, -e, leg.

befom'men, $S$., to get, receive. bellen, to bark.

$\mathfrak{B e r g}$, ber $-\mathfrak{e z},-\mathfrak{e}$, hill, mountain. beid)äf'tigt, busy.

bejdat'ten, to shade.

bejurei'ben, $S$., to describe.

beje'hen, $S$., to inspect, view.

Bepitz'er, der, -ż, -, owner.

bejon'derz, especially.

befier, better.

beit, best.

$\mathfrak{B c}(\bar{u} \mathfrak{d})^{\prime}$, Der, $-\mathfrak{Z},-e$, visit.

be $\left(\bar{u}{ }^{\prime} \mathfrak{d}\right) \mathfrak{e n}$, to visit.

Bett, daz, -ez, -en, bed.

Bett'becfe, bie, $-\mathfrak{n}$, bedcover, counterpane.

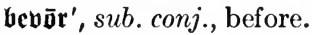

bewegt', moved; (of water) rough. Bewoh'ner, ber, $-\mathfrak{B},-$, inhabitant. bewoh'ten, to inhabit.

$\mathfrak{b} \mathfrak{z} \mathfrak{a} \mathfrak{h}$ 'len, to pay.

Bibel, bie, $-\mathfrak{n}$, bible.

Bildo, $\mathfrak{d a z},-\mathfrak{e} z,-e r$, picture.

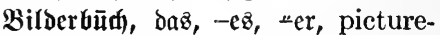

book.

[ticket.

Billett', (pron. Biljet'), סaz, $-\bar{z},-e$, billig, cheap.

binben, $S$., to tie, bind.

Birne, bie, $-n$, pear. 
Birnbaum, ber, $-\mathfrak{z}, \Perp \mathfrak{e}$, pear tree. bis, sub. conj., until ; prep. acc., till, up to.

bitten, S. (um, acc.), to ask, beg (for). bitte, please.

bleifen, $S .$, f., to remain, stay. Bleijtift, ber, $-\bar{z},-e$, lead pencil.

blitzen, to lighten, flash.

blühen, to bloom, blossom.

Blume, bie, $-\mathfrak{n}$, flower.

Blüte, bie, $-\mathfrak{n}$, bud, blossom.

bluten, bleed.

Bvocn, ber, $-\bar{z}, \mu$, bottom, floor.

Boot, baz, $-\mathrm{ez},-\mathrm{e}$, boat.

$\mathfrak{b} \ddot{\mathfrak{s}}$, wicked, evil, cross.

$\mathfrak{b} \ddot{\mathbf{j} j \mathfrak{c},} a d v$., cross.

brauden, to need, want, use.

braun, brown.

brav, honest, good.

breit, broad.

brennen, irr., to burn.

Bricf, Der, -ez, -e, letter.

Bricf'marfe, bie, $-\mathfrak{n}$, stamp (letter stamp).

Brillc, bie, $-\mathfrak{n}$, the spectacles.

bringen, irr., to bring.

Brubcr, ber, $-\mathfrak{z}, \pm$, brother.

Bube, ber, $-\mathfrak{n},-\mathfrak{n}$, boy.

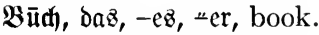

$\mathfrak{B} \overline{\mathfrak{u}} \mathfrak{d}$ ' 'ítabc, ber, $-\mathfrak{n} z,-\mathfrak{n}$, letter (of the alphabet).

\section{(5}

(5ent, ber, $-\mathbb{B},-$, cent.

(5hrift, ber, $-\mathfrak{c} n,-\mathfrak{c} n$, Christian.

bā, $a d v$., there ; sub.conj., as, since ; when.
$\grave{D a}$ 'blciben, $S .$, f., to stay there.

Iăch, Daz, $-\mathfrak{c} z,-\mu c r$, roof.

Dafür', for it, for them.

Dāmâals, at that time, then.

Iame, bic, $-\mathfrak{n}$, lady.

Dămit', adv., with it ; sub. conj., in order that.

Danfe, thank you.

Danfen, to thank (dat. of person). bant, then.

Daran', next to it, close to it.

Darauf', on it.

Darin', therein, in it, in them.

$\mathfrak{D a}_{\mathfrak{k}}$, sub. conj., that, so that.

Davŏn', about it, of it.

Deffe, bie, $-\mathfrak{n}$, cover.

bcin, poss. adj., thy, your.

benen, dat. pl., to whom.

benfen, irr. (au, acc.), to think (of).

DenII, co. conj., for.

ذcren, gen. fem. and $p l$., whose.

Dcricl'bc, the same.

Deijen, gen. mas. and neut., whose. Dcutid, adj., German.

Icutjdic, Der, adj.-noun, the German (man).

Dcutị)lăıı, ১aż, $-\mathfrak{z}$, Germany.

Didit, close.

Didfter, ber, $-\mathfrak{z},-$, poet.

biff, thick.

Iicb, Der, $-\mathfrak{e} \&,-\mathfrak{e}$, thief.

Sicustāg, dcr, $-\mathfrak{z},-\mathfrak{c}$, Tuesday.

Dicicr, this; the latter.

Dir (dat. of Du), to thee, to you.

Dŏd), yet, after all; used for emphasis: foumen 巨ic Dodf), do come! - ni(f)t, surely not.

Iof'tŭr, ber, $-\mathfrak{z},-\bar{u}$ 'ren, doctor.

Iuflar, ber, $-\mathfrak{z},-$, dollar.

Douncrn, to thunder.

Iun'tucrstāg $\mathfrak{g}$, Der, $-\mathfrak{z},-\mathfrak{e}$, Thursday. 
Dorf, daz, $-\mathfrak{e z}, \mu \mathrm{er}$, village.

braurzen, outside, $a d v$.

orci, three.

Irojdffe, bie, $-n$, cab.

Dut, thou, you.

Dumm, ״er, stupid.

Dututel, dark.

๖üuı, thin.

Dutra), prep. acc., through, by.

Dutrd' 'Iaufien, $S$., to run through.

Durd)la $\mathfrak{a}$ ' $\mathfrak{f} \mathfrak{c}$, $S$., to peruse hastily.

Durd) $=$ burd) daz.

Dirfin, irr., to be allowed, may (permission).

Duritig, thirsty.

\section{(5)}

$\mathfrak{e b e n}$, just, even.

$\mathfrak{c}^{\prime} \mathfrak{b} \mathfrak{c} \mathfrak{j} \mathfrak{D}$, just as ; likewise.

elhe , sub. conj., before.

cilen, to hasten.

(Gimer, Der, $-\not B,-$, bucket, pail.

cin, one, a, an.

cin'bilben, fick (dat.) -, to imag-

ine.

cin'gebir'bet, conceited.

cinige, several.

$\mathfrak{c i n}^{\prime} \mathfrak{m} \overline{\mathfrak{a}} \mathfrak{l}$, once, one time.

cinmâal', once upon a time; just;

ni(f)t - , not even.

(Fin'wolyuer, ber, $-\overline{8},-$, inhabitant.

(EItern, bie ( $p l$.$) , parents.$

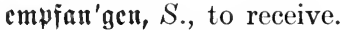

(5mpjang'zimmer, daz, $-\mathfrak{z},-$, reception-room, drawing-room.

empōr', adv., up.

empōr'halten, $S$., to hold up.

(snde, $\mathfrak{d} a z,-z,-n$, end. cudrid), at last, finally.

eng, narrow.

(England, Daz, $-\bar{z}$, England.

(Eng'länder, der, $-\bar{b},-$, Englishman.

cuglijă, English.

Enfel, ber, $-z,-$, grandson.

(En'felin, bie, $-\mathfrak{n e n}$, granddaughter. entge'gen, prep. dat., against, towards.

entge' $\mathfrak{g e n}=$ fommen, $S$. , f., to come to meet; to come towards.

$\mathfrak{e n t g e}^{\prime} \mathfrak{g e n}=\mathfrak{I a u f e n}, S ., f_{\text {., }}$ to run to meet.

entl)aup'ten, to behead.

er, he.

crben, to inherit.

Errbc, bie, -n, earth; auf ber -, on the ground.

$\mathfrak{e r i r r u} ' \mathfrak{c n}$, to rejoice, make glad. $\mathfrak{e r h a l}$ 'ten, $S$., to receive.

eriu'nern (an), to remind (of); fidf - (gen.), to remember.

erfen'nen, irr., to recognize.

erfun'bigen, fith - (nadf)), to inquire (after).

ernit, serious, earnest.

erïfï'nen, to open.

errö'ten, to blush.

$\mathfrak{c r} \mathfrak{i} \mathfrak{d} \mathfrak{l a}^{\prime} \mathfrak{g e n}, S$., to slay.

èrit, $a d j$., first ; $a d v$., only, not till. crwar'ten, to expect.

$\mathfrak{c r} \mathfrak{z} \mathfrak{\mathfrak { a }} \mathfrak{h} ' \mathfrak{I} \mathfrak{e n}$, to narrate, tell.

⿷匚⿳亠口冋, it.

(Ejel, Der, $-\bar{z},-$, donkey.

eil $\mathfrak{e n}, S$., to eat.

ctwă

what, any.

cud), dat. and acc. of ihr, you.

euer, poss. adj., your.

Guro'pa, $\mathfrak{d a z},-\bar{z}$, Europe. 
is

fagren, $S .$, f., drive; travel ; ride. $\mathfrak{F} \mathfrak{a} \mathfrak{h} \mathfrak{i} ' \mathfrak{f a r t c}$, bie, - $\mathfrak{n}$, tieket (railroad, ete.).

$\mathfrak{F} \mathfrak{a} \mathfrak{h} \mathfrak{h} \mathfrak{p l a ̄ a n}$, der, $-\mathfrak{z},{ }^{\mathfrak{c}} \mathfrak{c}$, time-table.

fallen, $S$., f., to fall.

falla, sub. conj., in ease.

זrămī'lic, bie, -n, family.

Farbc, bie, $-\mathfrak{n}$, color, dye.

Färber, ber, $-z,-$, dyer.

faul, lazy.

$\mathfrak{F} \mathfrak{a u l p c l} \mathfrak{p l}_{3}, \delta \mathfrak{c r},-\mathfrak{e},-e$, lazy fellow.

Feder, bie, $-\mathfrak{n}$, pen ; feather.

Feitto, der, $-c \mathfrak{s},-e$, enemy.

fellfen, to lack, to be wanting; waz fehlt bir, what is the matter with you?

Feldo, baz, -ca, -er, field.

Fenfter, baz, $-8,-$, window.

Fenitcrbanf, bic,

fern, far, distant.

Ferme, in ber -, in the distance.

fertig, finished, ready.

ieit, firm.

feit' $\mathfrak{h a l t e n}, S$., to hold fast.

Feucr, Daz, $-z,-$, fire.

jeucrwehr, bic, -cul, fire brigade.

fintoen, $S$., to find.

flciß̨ig diligent, industrious.

Flicge, bie, -n, fly.

fliegen, $S .$, f., to fly.

flicizen, $S .$, f., to flow.

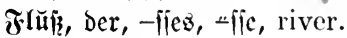

furt, away.

$\mathfrak{F r a g c}$, bie, - $\mathfrak{n}$, question.

fragen, to ask.

$\mathfrak{F}_{\mathfrak{r a n}}$ bie, -en, woman; Mrs. ; wife.

Fräulcin, baz, $-\bar{z},-$, young lady,

Miss.

[side.

freien, im -, in the open air, out- frei'gcbig, generous.

frei'iprechen, $S$., to aequit.

j̧rcitāạ, ber, $-\mathfrak{z},-\mathfrak{c}$, Friday.

fremo, strange.

Frembe, ber, adj. noun, stranger.

frreubc, bic, -n, the joy; vor -

for joy.

freuen, fid - , to be glad, rejoice;

cz freut midf), I am glad.

Frcutb, ber, $-\mathrm{ez},-\mathfrak{c}$, friend.

Jreunbin, bie, - nen, (female) friend.

freutolid, friendly.

$\mathfrak{F}^{\mathrm{r} c u m b l i d f f e i t}$, bie, $-\mathrm{en}$, the friend-

liness.

Frcundidaft, bie, -ch, friendship.

Fricde, ber, $-\mathfrak{n} z,-\mathfrak{n}$, peace.

fricren, $S$., to freeze ; ez friert midg,

I am cold.

friid), fresh.

Frit, Fred.

froh, glad.

frïh, early.

frü'hcr, formerly, earlier.

früh'itüufen (insep.), to breakfast.

fiihgren, to lead, conduet.

fïnf, five.

für, prep. acc., for.

fürdften, to fear; fid - vor (dat.),

to be afraid of.

fürz $=$ für $\mathrm{baz}$.

Fürit, ber, $-\mathfrak{e n},-\mathfrak{e n}$, prince.

Für'fitin, bie, -nen, prineess.

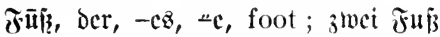

lang, two feet long.

ร)

\section{(3)}

(biabcl, bic, $-\mathfrak{n}$, fork.

$\mathfrak{g a n}_{3}$, adv., quite; $a d j$., whole, all, entire. 
gār, very ; - nich)t, not at all.

(Garten, Der, $-8, \pm$, garden.

(Särtuer, ber, $-\mathfrak{z},-$, gurdener.

geben, $S$., to give; $\mathfrak{c} \mathbb{B}$ gibt, there is or are.

Gebir'ge, $\mathfrak{b a z},-\mathfrak{z},--$, mountains, chain of mountains.

geb̄' 'ren, born.

gebrau'd)en, to use.

Geburtz'tāa $\mathfrak{g}$, ber, $-\mathfrak{e} z,-e$, birthday. (bedan'fe, ber, $-\mathfrak{n} z,-\mathfrak{n}$, thought.

$\mathfrak{g e g e n}$, prep. acc., against, towards. gehen, $S$., f., to go, walk; wie geht $\mathfrak{c} z$ bir, how are you?

$\mathfrak{g e h} \mathbf{j}$ 'ren, to belong.

(Geiit, ber, -cza, -er, spirit ; mind ; ghost.

(Geld, $\mathfrak{d a z},-\mathfrak{e z},-\mathfrak{c r}$, money.

gelin'gen, $S .$, f., imp. dat., to succeed.

gelo'ben, to vow.

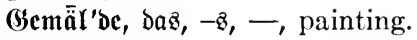

genūg', enough.

gern, or gerne, gladly, with pleasure, etc.; - haben, to be fond of, to like.

gejde $\mathfrak{e}^{\prime} \mathfrak{h} \mathfrak{e n}, S .$, i., imp., to happen.

(Ǵcjdenf', $\mathfrak{d} \mathfrak{z}-\mathfrak{c} z,-e$, present.

(Geid)id)'te, bie, $-\mathfrak{n}$, story ; affair.

geite'hen, S., to confess.

gcitern, yesterday.

geitrig, adj., yesterday's, of yesterday.

gewié,', certain.

(Gewit'ter, $\mathfrak{d} \mathfrak{a}, \bar{z},-\mathbb{z},-$, thunderstorm.

gie $\mathfrak{z}_{\mathfrak{z}} \mathfrak{e n}, S$. , to pour.

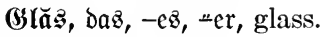

glauben, to believe.

gleid), $a d v$., at once; adj., likè, equal.
(Ślücf, Daż, $-\mathfrak{c}$, luck, happiness. glürffid), happy.

gliidflid)ermeije, luckily.

gulden, golden.

(b) ott, Der, $-\mathfrak{c B}$, God ; ㄹer, gods.

$\mathfrak{g r a b e n}, S$., to dig.

gr $\mathbf{v} \tilde{\mathbf{z}}_{2}$, "er, big, great; tall.

(Grrōoz'cltern, bie $(p l$.$) , grandpar-$ ents.

Girōiz'mutter, die, *, grandmother.

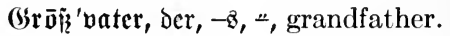
grün, green.

grüizen, to greet, bow; send love or regards.

gūt, good, kind; adv., well; all right.

$\mathfrak{g u t}^{\prime} \mathfrak{h} \mathfrak{e r} \mathfrak{z} \mathfrak{i g}$, kind-hearted.

\section{$\mathfrak{S}$}

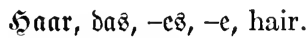

hagelin, to hail.

$\mathfrak{h a l b}$, half; - orei, half past two. $\mathfrak{g} \mathfrak{a l} s$, ber, $-\mathfrak{e z}, \pm \mathrm{e}$, neck.

$\mathfrak{h a l t e n}, S$., to hold.

$\mathfrak{s a n d}$, bie, -e, hand.

hand'haben, (insep.), to handle.

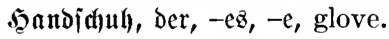

j̧ants, Jack.

$\mathfrak{h a r t} \mathfrak{t}^{\prime} \mathfrak{c} \mathfrak{c} z \mathfrak{i g}$, hard-heàrted.

$\mathfrak{s a j e}$, ber, $-\mathfrak{n},-\mathfrak{n}$, hare.

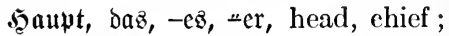

$-\tilde{i} \operatorname{tra} \tilde{\mathfrak{B}} \mathrm{c}_{\text {main }}$ street.

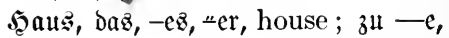

at home; nadi -e, home.

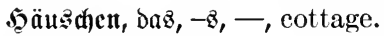

$\mathfrak{5} \mathfrak{a} \mathfrak{s t u ̈ r}$, bie, $-\mathfrak{e n}$, street door. heven, $S$., to lift.

sec ft, Daz, $-\mathfrak{e z},-\mathfrak{c}$, copy book.

heim'bleiben, $S .,\{$., to stay at home. Secinrid), Henry. 
hei'raten, to marry.

heipen, $S$., to be called.

heiter, cheerful.

$\mathfrak{h e l f i n}, S .$, dat. of person, to help. hěr, hither.

h) raus', out (towards the speaker). hércin', in (towards the speaker); come in!

herein'fommen, $S .$, f., to come in. herein'laufen, $S ., i$. to run in. her'fommen, $S ., f$. , to come from. 5ecr ber, -n, -en, master, lord; gentleman ; Sir; Mr.

h)̌rum', around.

herum'ipringen, $S ., \quad$ i., to jump around.

$\mathfrak{5 e r} 3$, bas, $-\mathfrak{c n} z,-\mathfrak{c n}$, heart. heulcri, howl.

heute, to-day; - frith, early this morning; - morgen, this morning.

heutig, adj., to-day's, this day's. hicr, here.

hiciing, adj., local, of this place. Dimmel, Der, $-\mathfrak{z},-$, sky, heaven. hrun, thither.

$\mathfrak{h}$ tua $\mathfrak{b}^{\prime}$ down (from the speaker). hinab'fallen, S., f., to fall down. hinauf'Iaufen, $S .$, f., to run up. hinauf'ipringen, $S ., \quad f_{.}$, to jump up.

hinaus' out (from the speaker). hinaus'fallen, S., f., to fall out. binaus' $\mathfrak{g c h e n}, S .$, f., to go out. binats'jagen, to chase out. bincin', in (away from the speaker).

bincin'laufen, S., f., to run in. hincin'treten, $S .$, f., to step in. binfen, to limp.

binten, $a d v$., behind, at the back.
Ginter, prep. dat. and acc., behind. hinterge' $\mathfrak{h e n}, S$., to deceive. hinterlai'jen, $S$., to bequeath. himun'ter, down (from the speaker). himun'terielgen, $S$., to look down. $\mathfrak{h} \overline{\mathbf{v}} \mathfrak{d})$, höker, high.

$\mathfrak{5} \overline{\mathrm{v}} \mathrm{f}$, Der, $-\mathrm{ez}, \pm \mathrm{e}$, yard, court. $\mathfrak{h}$ ufien, to hope.

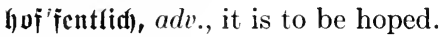
$\mathfrak{h} \overline{\mathfrak{y}} \tilde{y}(\mathbf{i d})$, polite.

$\mathfrak{h} \mathfrak{o l e n}$, to fetch, get, bring.

$\mathfrak{j} \cup \mathfrak{l}_{3}, \mathfrak{D a} s,-\mathfrak{c} \mathbb{z},-\cdots \mathfrak{c r}$, wood. h) ören, to hear.

5) 0 tel', daz, $-\mathfrak{z},-\mathfrak{z}$, hotel.

hiibijd), handsome, pretty.

Şund, Der, -ez, -e, dog.

$\mathfrak{5 u m b e r t , ~ D a \& , ~}-\mathfrak{z},-\mathfrak{c}$, hundred.

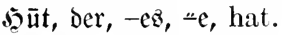

hüten, to tend, guard.

\section{$\mathfrak{I}$}

id), I.

ifm, dat., to him, for him.

ifin, acc., him.

if)nen, dat., to them, for them.

$\mathfrak{J h m e n , ~ d a t . , ~ t o ~ y o u , ~ f o r ~ y o u . ~}$

$\mathfrak{J h r}$, poss. adj., your.

ihr, dat. pron., to her, for her; poss.

adj., her; their; pron., you.

in' rethalben, for her or their sake.

ih)'retwegen, for her or their sake.

im $=$ in bem.

immer, always.

in, prep. dat. and acc., in, into.

intōm', sub. conj., while.

ins $=$ in $\mathfrak{d} \mathfrak{a}$.

iutterefîant', interesting.

inwiciern, sub. conj., how far. inmicweit, sub. conj., how far.

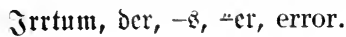




\section{$\mathfrak{I}$}

jāa, yes; jă, why, of course, to be jagen, to hunt, chase. [sure. Jabr, $\mathfrak{d} \mathfrak{z},-\mathfrak{c} \boldsymbol{z},-\mathfrak{c}$, year. $\mathfrak{J a ̆}$ 'mūar, ber, $-\mathfrak{z},-e$, January. jeder, every.

jedcrmann, everybody. icner, that; the former.

jetzig, adj., present.

ickit, now.

Juli, Der, $-\bar{z}$, July.

jung, $\Perp$ er, young.

Junge, ber, $-n,-n$, boy.

Iuni, ber, $-\mathfrak{z}$, June.

\section{I}

Sinijer, ber, $-\mathfrak{B},-$, emperor.

$\Re \mathfrak{i} \mathfrak{l} \mathfrak{b}, \grave{b a z},-e \mathfrak{z}, \mu e r$, calf.

$\mathfrak{f} \mathfrak{d} \mathfrak{l t}, \stackrel{\sim}{\mathrm{er}}$, cold.

গămĕrn̄̄o', ocr, -en, -en, comrade.

Siarl, $-\mathbf{z}$, Charles.

Satze, bie, -n, cat.

faufen, to buy.

fcin, adj., no, not any.

§ellner, Der, $-\mathfrak{z},-$, waiter.

Sicllncrin, bie, -nen, waitress.

fennen, irr., to know.

Sind, baz, $-e z,-e r$, child.

Sirdie, bie, $-n$, church.

Sleid, Daz, $-\mathrm{ez},-\mathrm{er}$, dress.

fleiben, to dress.

$\mathfrak{f l c i n}$, small (of size), little.

flingeln, to ring the bell.

flingen, $S$., to sound.

flopfen, to knock; es flopft, there is a knock.

$\mathfrak{f l} \overline{\mathfrak{u}} \mathfrak{g}$, $=\mathrm{er}$, clever, smart.

Sinabc, der, $-\mathfrak{n},-\mathfrak{n}$, boy.

Sï̈hin, die, -nen, cook (woman).
Siofier, Der, $-z,-$, trunk.

Siohle, dic, $-\mathfrak{n}$, coal.

fommen, $S$., f., to come.

Si ünig, ber, $-z,-e$, king.

fönnen, irr., to be able to, can.

Si opf, ber, -ez, «e, head.

foiten, to cost.

Sirühc, bie, $-n$, crow.

franf, ill, sick.

[ness.

Siranflycit, die, -en, illness, sickfraken, to scratch.

Sircioc, bie, $-\mathfrak{n}$, chalk.

Sirūg, ber, $-\mathfrak{e z},-e$, pitcher, jug.

$\boldsymbol{\Re} \breve{u} \mathfrak{d} \mathfrak{c}$, bie, $-\mathfrak{n}$, kitchen.

Niuh), bie, $" e$, cow.

fiühl, cool.

furic'ren, to cure.

furrz,

\section{$\mathfrak{L}$}

lăchen, to laugh.

$\mathfrak{L a d e n}$, Der, $-\mathbb{z}, \pm$, shop, store.

$\mathfrak{l a h m}$, lame.

$\mathfrak{I a m m}, \mathfrak{d a z},-\mathfrak{e z}, \pm e r$, lamb.

Sampe, bie, $-\mathfrak{n}$, lamp.

Qanb, Das, -ez, -er, land, country; auf bem $-e$, in the country.

Lanomann, Der, $-\mathfrak{z},-\cdots e r$, Randleute, farmer.

Iang, "er, long.

$\mathfrak{l a n g e}, a d v$., for a long time.

$\mathfrak{l a n g} \mid \bar{a} \mathfrak{m}$, slow.

Qärm, ber, -ęz, noise.

Iailin, S., to let, have.

Iaufen, $S .$, f., to run.

laut, lond.

$\mathfrak{Q} \mathfrak{c b c n , ~} \mathfrak{b a z},-\mathfrak{z},-$, life.

Ieben, to live.

$\mathfrak{L c h c n s j a h r , ~} \mathfrak{d a z},-e z,-e$, year of one's life. 
legen, to lay.

lehren, to teach.

$\mathfrak{L e h r e r}$, ber, $-\mathbf{z},-$, teacher.

Lehrerin, bie, -nen, (female) teacher.

Leib, Der, -ez, -er, body.

leid)t, easy ; light.

leib, $\mathfrak{e} \mathfrak{B}$ tut mir -, I am sorry ; er tut mir -, I am sorry for him.

leihen, $S$., to lend.

lernen, to learn.

Icicn, $S$., to read.

le kzt, last.

Icute, bie, $p l$., people.

$\mathfrak{l i c b}$, dear.

lieven, to love.

licber, comp. adv., rather, more gladly, better.

liebiten, am -, sup. adv., most gladly; cr ipielt am -, he prefers to play.

Lied, daz, $-\mathfrak{e z},-\mathfrak{e r}$, song.

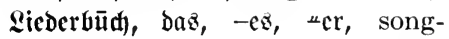
book.

liegen, $S$, to lie.

$\mathfrak{l o b e n ,}$ to praise.

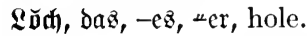

Q⿻̈jffel, ber, $-8,-$, spoon.

löjden, to extinguish.

Quft, bie, "e, air.

lügen, $S$., to lie, tell a lie.

lujtig, merry.

\section{9)}

mădyen, to do, make.

M(äbd)cn, $\mathfrak{d a z},-\mathfrak{z},-$, girl, maiden. Mai, ber, $-z,-e$, May.

$\mathfrak{M a ̄ l}$, daz, $-\mathfrak{e z},-e$, time; zum criten - , for the first time.

$\mathfrak{m a l e n}$, to paint.
Maler, ber, $-8,-$, painter.

Malerin, bie, -nen, (female) paint-

er.

măn, indecl., one, people, they ; jagt, it is said.

manther, many a ; $p l$, many.

Maann, Der, $-\mathfrak{c} \&$, $\Perp \mathrm{er}$, man, husband. Märd\}en, daz, -z, -, story, fairytale.

Min̆ric', -\$, Mary.

Miarf, bie, -, mark (German money $=24 \mathrm{cts}$.).

Miarftitrajįe, bic, -n, Market-street. Miajt, ber, $-\mathfrak{e} \&,-\mathfrak{e n}$, mast.

mehr, more.

mehrere, several.

mein, poss. adj., my.

mei'netwegen, for my sake.

meijt, most.

meijtens, $a d v$., mostly.

Mienid, Der, -en, -en, man, human

being; fellow.

Meiīer, Das, $-8,-$, knife.

midh, acc., me.

9)icte, bie, -n, rent.

micten, to rent, hire.

Mitat), bie, milk.

Mitlliōn', Die, -en, million.

Mĭun'te, bic, -n, minute.

mir, dat., to or for me.

mit, prep. dut., with, along with.

mit'bringen, irr., to bring along.

mit'gehen, $S .$, f., to go along.

mit'nehmen, $S$., to take along.

mit'ipielen, to play with.

Mittāg̣, der, $-\mathfrak{z},-e$, noon, midday ;

$z^{\mathfrak{l}}$ - e e $[$ ert, to dine.

Mittwo vd), Der, $-\mathbb{z},-\mathfrak{c}$, Wednesday. mügen, irr., to like to, care to;

may.

Miōnăt, bcr, $-\mathfrak{s},-\mathfrak{e}$, month. 
Miōutāg, ১er, $-\bar{z},-\mathfrak{c}$, Monday.

Mivrgen, ocr, $-z_{,}$, , morning. murgen, $a d v$., to-morrow.

morgets, of a morning; in the morning.

mïbc, tired.

miifĩen, irr., must, to be obliged to, to have to.

Miutter, bic, $=$, mother.

Mü̈z̨c, bie, $-\mathfrak{n}$, cap.

\section{$\mathfrak{P}$}

māa), prep. dat., after; to ; according to ; bie $\mathfrak{u b r}$ gcht -, the clock is slow.

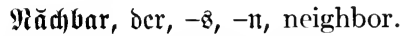
năd) bēm', sub. conj., after.

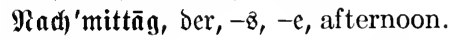
näd)it, next.

Măad)t, bie, "e, night; nady)tz, at night.

Rad)tigall, bie, -cn, nightingale. nahe, near; comp., näher, näd)jt.

$\mathfrak{R a m e}$, Der, $-\mathfrak{n} \mathbf{b},-\mathfrak{n}$, name.

$\mathfrak{n a n z} \tilde{z}$, wet.

ncben, prep. dat. and acc., beside, next to.

nebenan, next door.

nel)men, $S$., to take.

nein, $a d v$., no.

Pielfe, bie, $-\mathfrak{n}$, pink.

nenten, irr., name, to call.

nett, nice.

neu, new.

neun, nine.

nicht, not ; - mebr lange, not much

longer.

nid)ts, nothing; - $\mathfrak{a l z}$, nothing but.

nicocr, down. nicbrig, low.

niemā $\mathfrak{l}$, never.

nicmant, nobody.

nŏd), still; yet; - ein, one more, another; - nidft, not yet; weder ....nody, neither... nor.

$\mathfrak{N u m m e r}$, bie, $-\mathfrak{n}$, number. nūn, now ; as exclamation, well ! $\mathfrak{n u} \mathbf{r}$, only.

\section{$\mathfrak{D}$}

$\breve{\mathbf{v} b}, s u b$. conj., whether, if. obcr:, above, on top ; upstairs. vbglcidh', sub. conj., although.

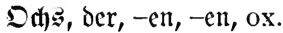

oder, co. conj., or.

$\bar{D} \mathfrak{i c n}$, der, $-\mathfrak{B}, \mu$, stove, oven. vifin, $a d j$., open.

bifinen, to open.

๖̊ft, often; comp., öfter.

$\overline{\mathbf{v}} \mathfrak{n} n \mathbf{c}$, prep. acc., without.

$\boldsymbol{D h r}, d a z,-e z,-e \mathfrak{n}$, ear.

Dntel, Der, $-B,-$, uncle.

Drt, ber, -ęz, small town.

\section{$\mathfrak{P}$}

$\mathfrak{B a ̆ p i c r ' , ~} \delta a \mathfrak{z},-\mathfrak{z},-e$, paper.

waifen, to fit.

$\mathfrak{B a} \mathfrak{a}^{\prime} \hat{t} \mathrm{t} \breve{\mathfrak{r}}$, ber, $-\overline{\mathfrak{z}},-\overline{\mathfrak{v}}$ 'ren, pastor, minister.

$\mathfrak{B} f e^{\prime} n i g$, ber, $-\mathbb{z},-e$, pfennig.

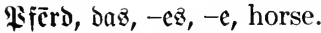

$\boldsymbol{p} \mathfrak{f l a n}_{\mathfrak{c}} \mathfrak{c n}$, to plant.

pifiuafen, to pick, pluck.

Silatz, ber, $-e \mathfrak{z},-e$, place, room.

İvitfarte, bie, $-\mathfrak{n}$, postal card. wräct)tig, magnificent.

Prä́fïbent', ber, -en, -en, president. 
Prciz, Der, $-\mathfrak{c} z,-\mathfrak{c}$, price.

$\mathfrak{A r i t} z$, ber, $-\mathfrak{e n},-\mathfrak{e n}$, prince.

'Brinzci'ïn, bie, -nen, princess.

$\mathfrak{B u l t}, \mathrm{Daz},-\mathfrak{e} \mathbf{z},-e$, desk.

\section{$\mathfrak{i}$}

Pand, bcr, $-\mathfrak{e z}, \mu e r$, edge, brink.

raten, $S$., to advise; guess.

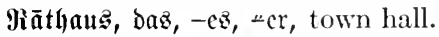

$\mathfrak{i n ̄ t s h e r r , ~ b c r , ~}-\mathfrak{n},-\mathfrak{c n}$, councilman.

raud)en, to smoke.

Sied)nung, bie, -cn, bill, account. red)t, right; - - haben, to be right.

Micoc, bic, $-n$, speech; talk.

reden, to talk, speak.

9iegen, ber, $-\mathfrak{z},-$, rain.

Picgenidjirm, ber, $-\mathfrak{z},-\mathfrak{e}$, umbrella. Picgenwetter, $\delta a z,-\varepsilon$, rainy weathreguen, to rain.

[er.

reid), rich.

Picidf)tūm, bcr, $-\mathbb{z}, \pm \mathfrak{c r}$, riches.

reif, ripe.

rein, clean.

reijen, $f .$, to travel.

Picijende, ber, adj.-noun, traveler.

renuen, irr., f., to run.

Piid)ter, Der, $-z,-$, judge.

rid)tig, right, correct.

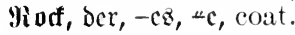

rollen, to roll.

Ii vic, bie, $-\mathfrak{n}$, rose.

Si iuffen, ber, $-z,-$, the back.

Siudcr, ১as, $-8,-$, oar ; rudder.

rubern, to row.

rufen, $S$. , to call.

ruhlgig, quiet.

Săduc, bic, $-\mathfrak{l l}$, thing, affair.

Єad́, ber, $-\mathfrak{c}$, ${ }^{-} \mathrm{c}$, sack. jaggen, to say, tell.

Entz, Der, $-\mathfrak{C} \mathbb{Z}, \stackrel{\sim}{ } \mathfrak{c}$, sentence.

$\Theta \mathfrak{G} \bar{a} \mathfrak{j}$, baz, $-\mathfrak{c} \dot{z},-c$, sheep.

idümen, fith -, to be ashamed.

idfeinen, S., to shine, appear.

idfelten, S., to scold.

jdicnten, to make a present of, present, give.

ididen, to send.

Edri许, daz, $-\mathfrak{c} z,-\mathfrak{c}$, ship.

Edinifïr, bcr, $-z,-$, boatman.

id) lajen, s., to sleep.

Ed)lafzimmer, das, -s, -, bedroom.

id)Iagen, $S$., to beat, strike.

id)ledt, bad, badly.

id)licisen, S., to close, shut, lock.

id)licis lida, finally.

idylimm, bad.

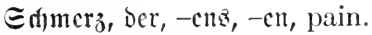

id)mutrig, dirty.

Edinciocr, ber, - - , , tailor.

Ed)uciocrin, Dic, -nen, dressmaker.

idfuclf, quick.

(d) ōn, already ; - gut, all right.

(d) inn, beautiful.

Edhrauf, Der, -ces, closet.

idhrciben, S., to write.

Ed)ritt, Der, $-\mathfrak{c}$,,$-\mathfrak{c}$, step ; f(d)ucllen Ed)rittes, with quick steps.

E(t)uld, ber, $-\mathfrak{c}$ \&, $-\mathfrak{c}$, shoe.

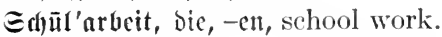
Eañl'aufgabc, dic, -It, school lesson.

[book.

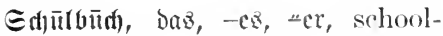
Ed)ule, bic, -n, school; zur Edfulc, to school.

Edütcr, Der, -8, -, scholar, pupil.

Edjülcrin, bic,-nen, (female) scholar. 
Ed)ūlfămĕrāà', der, $-\mathfrak{e n},-\mathfrak{e n}$, schoolmate.

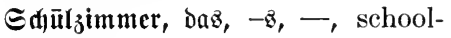
room.

巨ałwalbe, bie, $-\mathfrak{n}$, swallow.

(d) wanrz, black.

id)weigen, $S$., to be silent.

巨đ)wcin, $\mathfrak{D a z},-\mathfrak{c} z,-\mathfrak{c}$, pig, swine.

(d)wēr, difficult, hard ; heavy ; -

(beld, much money.

Ediwciter, bie, $-\mathfrak{n}$, sister.

ied)

Ece, bie, $-\mathfrak{n}$, sea; an bie -, to the sea shore.

See, der, $-\mathfrak{z},-\mathfrak{n}$, lake.

jehen, $S$., to see.

jehr, very.

jein, his ; its.

jeit, prep. dat., since; sub. conj., since.

jeitbēm', sub. conj., since.

ielbit, self ; idf - , I myself ; $a d v$., even.

jelig, blessed ; late, deceased.

jelten, rare.

jenben, irr., to send.

jeksen, to set, place, put; fitc) -, to sit down, seat oneself.

ङie, nom. and acc., you.

fie, nom., she; they; acc., her; them.

jieben, seven.

jingen, $S$., to sing.

jitzen, $S$., to sit.

$i \overline{0}$, so, thus.

jōgar', even; - nidft, not even.

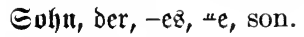

foldier, such a.

Eŏloāt', Der, -en, -en, soldier.

jollen, irr., am to ; shall; idd follte, I ought to.
Eummer, der, $-\mathfrak{B},-$, summer. junderi, co. conj., but.

Som' $\mathfrak{a b e n t}$, Der, $-\mathfrak{z},-e$, Saturday. Evute, bie, $-n$, sun.

Eัuntāa ger, $-\mathfrak{z},-\mathfrak{e}$, Sunday.

joutit, else.

jōviel, so much.

ipār $\mathfrak{i} \bar{a} \mathfrak{m}$, saving.

ipät, late ; fpäter, later, later on.

Epiel, daz, $-\mathfrak{z},-e$, play.

ipiclelt, to play.

Epiciplat, Der, -ez, \#е, playground.

iprěç)en, S., to speak, talk.

Eprid)wort, $b a z,-e z$, $=2 r$, saying, proverb.

ipringen, $S$. . $\{$., to spring, jump.

Staat, der, $-e z,-e n$, state.

Etadt, Die, $\Perp$ e, town, city.

Etall, Der, $-e$ z, $-e$, stable, stall.

itammen (auz), to hail, descend (from).

jtarf,

itatt, prep. gen., instead of.

iteffen, to stick, place, put.

itehen, $S$., to stand.

iteigen, $S$. , f., to mount, rise.

Etein, der, $-\mathfrak{e z},-\mathfrak{c}$, stone.

itellen, to place, put.

iterben, $S .$, f., to die.

Etern, ber, -ez, -e, star.

Etimme, bie, $-n$, voice.

Etodf, ber, $-e z, \Perp e$, stick.

it $\overline{0}$ ह̨en, $S$., to push.

itrafen, to punish.

હtrāizice, die, $-\mathfrak{n}$, street.

Etreid, Der, $-e \mathfrak{B},-e$, trick.

itreng, strict.

Etrid, Der, $-\mathfrak{e z},-\mathfrak{e}$, rope.

Єtrumpf, ఎer, $-\mathfrak{e z}, \pm e$, stocking.

Etüu, $D a z,-e z,-e$, piece. 
Student', ber, $-\mathfrak{e n},-e n$, student.

Stuben'tin, bie, -nen, (female) student.

itubie'ren, to study.

Stuhhl, ber, -ez, $״ e$, chair.

Stumbe, bie, $-\mathfrak{n}$, hour ; lesson.

iūden, to seek, look for.

Siidocutidhland, daz, $-z$, South Germany.

\section{$\mathfrak{I}$}

Tajel, bie, $-\mathfrak{n}$, slate, blackboard.

$\mathfrak{T} \overline{\mathfrak{a}} \mathfrak{g}$, ber, $-\mathfrak{e} z,-e$, day ; alle $\mathfrak{T a g e}$, every day; den - barauf, the next day.

$\mathfrak{T} \overline{\mathfrak{a}} \mathfrak{l}, \delta \mathfrak{a z},-e \mathfrak{z}, \pm \operatorname{er}$, valley.

Tanne, bie, $-\mathfrak{n}$, pine tree.

Tamnenvalb, ber, -ezz, forest.

Tante, bie, $-\mathfrak{n}$, aunt.

tanzen, to dance.

Tajde, bie, $-\mathfrak{n}$, pocket.

$\mathfrak{T a l i e}_{\text {, bie, }}-\mathfrak{n}$, cup.

$\mathfrak{I a u j e n d , ~ b e r , ~}-\mathfrak{z},-\mathfrak{e}$, thousand.

$\mathfrak{T e e}$, ber, $-\mathfrak{B}$, tea.

teil'nehmen, $S$. , to take part, participate.

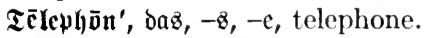

tēlephonic'ren, to telephone.

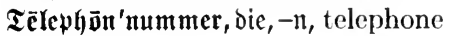
number.

teuer, dear.

tici, deep

Tier, daz, $-\mathfrak{e z},-e$, animal.

Tiute, bie, $-\mathfrak{n}$, ink.

Tijđ), ber, $-\mathfrak{c} z,-\mathfrak{e}$, table.

Ivdter, bie, $״$, daughter.

$\mathfrak{T} \overline{\mathfrak{o}}, \boldsymbol{b a z},-\mathfrak{e} z,-\mathfrak{e}$, gate.

tōt, dead.

tōt'ífhlagen, S., to kill. träge, lazy.

tragen, $S$. , to carry.

traurig, sad.

treīen, $S$., to meet; strike.

treiben, $S$, to drive.

Treppe, bie, $-n$, stairs.

treten, $S .$, f., to step.

trinfen, $S$., to drink.

trïiten, to comfort.

trots, prep. gen., in spite of.

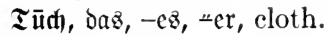

tutt, $S$., to do.

Tür, bie, -en, door.

Turm, ber, $-\mathfrak{e z}, \mu \mathfrak{c}$, tower, steeple.

\section{lit}

über, prep. dat. and acc., over, above; about.

überietz'en, to translate.

ü'berjetzen, to put across, set over.

$\mathfrak{l l h r}$, bie, -en, elock; watch; um wie viel -, at what o'clock, at what time.

$\breve{\mathfrak{u} m}$, prep. acc., around; for ; fedfz llhr, at six o'clock.

$\mathfrak{u m} \ldots \mathfrak{z}^{\mathfrak{u}}$, in order to.

um'hauen, $S$. to chop down.

$\mathfrak{u m h e r}$, around.

$\mathfrak{u m s}=\mathfrak{u m}$ bas.

un'artig, naughty.

und, co. conj., and.

un' $\mathfrak{g} \mathfrak{c} \mathfrak{x a ̈ h r}, a d v$., about.

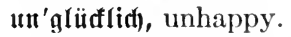

un'gliigflid)erweije, unluckily.

Ilniverjittät', die, -en, university.

utt'rcif, unripe.

uns, dat. and acc., us.

uı'jd)uldig, innocent.

unier, our.

unten, below, downstairs. 
unter, prep. dat. and acc., under; among.

[under.

un'tergel)en, S., f., to set; sink, go Iluterhal'tuug, bic, -en, conversation; entertainment.

\section{B}

Sater, ber, $-\xi, \pm$, father.

Baterlăno, baz, -ç, father-land.

verbin'Den, $S$., to bandage.

Bicrbrč'd)ell, bos, $-\bar{z},-$, crime.

Berbrě' 'd)er, ber, $-\mathbf{z},-$, criminal.

$\mathfrak{v e r g c} \mathfrak{b e n}, S$., to forgive.

vergei'jen, s'., to forget.

verhei'raten, fid) - , to marry, get married.

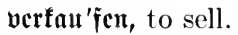

verlic'ren, $S$., to lose.

vermic'ten, to rent (out).

verren'fen, to sprain.

verid)fic' 'įcll, $S$. , to lock.

veripic'len, to lose in play, gamble away.

verite'lyen, S., to understand; daz beriteht ficf), that is understood. verīin'then, to try.

Bermand'te, Der, $-\mathfrak{n},-\mathfrak{n}$, adj.-noun, relation.

Better, ber, $-\mathfrak{z},-n$, cousin (male). vicl, much.

vicle, many.

viclfcid)t', perhaps.

vicr, four.

Biertel, ber, $-\mathfrak{z},-$, quarter: ein - orei, quarter past two.

Bogel, ber, $-\bar{z}, \pm$, bird.

Bolf, bas, $-\mathfrak{c} B, \mu \mathrm{cr}$, people, nation. Bolf:rlico, $\downarrow a z,-c z,-e r$, folk-song. volf, full (of).

$\mathfrak{v} \breve{\mathfrak{o m}}=$ bon bem. voun, prep. dat., of ; by ; from.

$\mathfrak{v} \bar{v} \mathbf{r}$, prep. dat. and acc., before; in

front of ; ago; die $\mathfrak{u h r}$ geht vor,

the clock is fast.

$\mathfrak{v} \overline{\mathfrak{v}} \mathbf{r}^{\prime} \mathbf{g} \mathfrak{c}$ tern, day before yesterday.

\section{$\mathfrak{B}$}

wadjien, $S .$, f., to grow.

$\mathfrak{W a g e n}$, ber, $-\mathfrak{z},-$, carriage, cart, wagon.

wahr, true.

während, prep. gen., during.

wäl)reno, sub. conj., while.

Wiahrlycit, bie, -cn, truth.

Miald, bcr, $-e \mathfrak{B}, \mu e r$, wood, forest.

Kannd, bie, «e, wall.

wann, inter., when.

warm, warm.

warten (auf, $a c c$. ), to wait (for).

wărŭm', why.

wăs, what; - für, what kind of.

$\mathfrak{X i a ̈ j} \mathfrak{d} \mathfrak{c}$ c, bie, wash, linen.

wajiden, $S$., to wash.

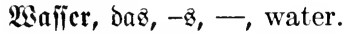

$\mathfrak{L i s e} \mathfrak{y}$, der, $-\mathfrak{c} z,-e$, road, way; dez

-ez gehen, to go on one's way.

$\mathfrak{w c} \mathfrak{g}$, away.

wegen, prep. gen., on account of.

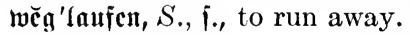

wch; - tun, to hurt.

wcil, sub. conj., because.

:scile, bie, leisure, time.

wcincn, to cry, weep.

Iscije, die, -nt, way, manner.

wcirs, white.

weit, far.

weld)er, which.

wēm, to or for whom.

$\mathfrak{w e} \mathfrak{n}$, whom.

wenden, irr., to turn. 
weniq, little (in quantity).

wenige, few.

wenn, sub. conj., if ; when; whenever; - a udf $)$, even if.

wēr, who.

wērben, $S ., f_{.,}$to become, grow, get. wěrien, $S$., to throw.

Wierf, Daß, $-\mathrm{e} z,-\mathrm{e}$, work.

wert, worth.

weilen, whose.

Bsciten, Der, -8 , west.

$\mathfrak{B a c t t e r}, \mathrm{daz},-\mathfrak{z}$, weather.

wiber, prep. acc., against.

wiberite'hen, $S$., to resist.

wie, how ; as ; like.

wicber, again.

micberlyo'len, to repeat.

wie'berholen, to bring again.

wie'berfommen, $S ., f_{.}$, to come again. $\mathfrak{R} \mathfrak{s i}(\mathfrak{l}) \mathfrak{e} \mathfrak{l m},-\mathfrak{z}$, William.

$\mathfrak{X}$ ind

$\mathfrak{W i n t e r}$, Der, $-\mathbb{B},-$, winter.

wiifen, irr., to know.

wō, where.

$\mathfrak{B} \mathfrak{v}$ d)e, bie, $-\mathfrak{n}$, week.

wofür', for what, for which.

woljin', where, whither.

wohl, well ; probably ; jamohl, yes indeed.

wohnen, to dwell.

[to.

wollen, irr., will, want to; intend womit', with which, with what.

morauf', upon which.

worin', in which, wherein.

KBort, bas, $-\mathfrak{c} z,-c$, word.

$\mathfrak{w} \mathfrak{v}_{3} \mathfrak{u}^{\prime}$, whereto, for what reason.

wun'scrid) ön, very beautiful.

Riurm, Der, $-\mathrm{c} B,-2 \mathrm{cr}$, worm. jäl)lelt, to count.

zchin, ten.

zeigen, to show.

3eit, bie, -en, time.

Zcitung, bic, -en, newspaper.

zerbre 'd'd)

zerial'fen, $S .,\{$., to fall to pieces, to

decay.

zerrei'izen, $S$., to tear.

zertre'ten, $S$. , to trample (down).

zicmlid), fairly, moderately ; -

vicl, pretty much.

3immer, bas, $-\xi,-$, room.

Bimmerbedfe, bic, $-n$, ceiling.

$3^{\mathfrak{u},}$ prep. dat., to; - Soalje, at home.

zu, adv., too; shut, closerl.

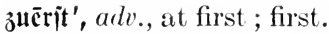

Jujric'Den, satisfied, contented.

$3 \overline{\mathfrak{u}} \mathfrak{g}, \mathrm{Der},-\mathfrak{e} z,-e$, train.

$3^{\mathfrak{u}} \mathfrak{h}$ örcu, to listen.

$3^{\mathfrak{u}}$ 'rujert, $S$., to call to.

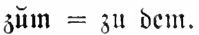

$\left.z^{\prime \prime} \mathfrak{m a d}\right) \mathfrak{n}$, to shut.

outurüt', back.

jurüd'f 'vm mett, S., f., to come back. zuriuđ'jełzen, to put back.

$z^{\text {urüat }}$ 'tragen, S., to carry back.

zujam'men, together.

jwa zig, twenty.

3wei, two.

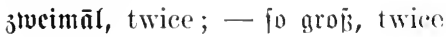

as big.

zwijd)en, prep. dat. and acce, be-

tween.

joülí, twelve. 


\section{ENGLISH-GERMAN}

A

a, an, ein; not -, fein.

able, be - to, fönnen, irr.

about, prep., um (acc.); talk -,

ipred)en über $(a c c$.$) ; adv., umber'.$ about, (nearly) adv., un'gefähr.

above, prep., ïber (dat. and acc.) ; $a d v$., oben.

according to, nāa) (dat.).

account, on - of, wegen (gen.); on that -, bezmegen.

ache, weh tum, tat weh, weh getan; idjmerzen.

acquit, frei'iprecten, iprad) frei, frei= gefprodfen.

across, put -, set -, über'fetzen.

advise, raten, riet, geraten, er rät, (dat.).

affair, Sădbc, bie, -n; Bejdjdyte, bie, $-n$.

afraid, to be -, fidi) fürdften (of, vor, dat.).

after, prep., nach (dat.) ; adv., năd)= her'; sub. conj., năd)dēm'.

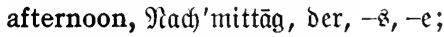
in the -, ১ez Rad)mittagż.

again, mieder.

against, prep., gegen, mider (acc.). ago, vŏr (prep. dat.); two days bŏr ztwei Iagen.

[Freien. air, \&uft, bie, $-e$; in the open air, im all, all.

allowed, to be - to, bürfen, irr. almost, beina'be, bald. along, - with, mit (dat.). already, $f(d) \overline{0}$.

also, audf).

although, sub. conj., obgleidg', $\mathrm{ob}=$ wohl'.

always, immer.

America, $\mathfrak{A} m \bar{e}$ rifīā, $\delta a \bar{z},-\bar{z}$.

American, $\mathfrak{A}$ mērifāa'ner, der, $-\bar{z},-$;

(woman) $\mathfrak{A}$ mērifā'nerin, bie, -nen. American, adj., amērifāa'nifł́). among, prep., unter (dat. and acc.), and, co. conj., und.

animal, Tier, $b a z,-e z,-e$.

another, (additional) nody ein;

(different) ein an'berer; one -, einan'ber, fidid.

answer, ant'worten (insep. dat. pers.).

apple, $\mathfrak{A p f e l}$, der, $-\not{z}, \Perp$. apple tree, Îpfelbaum, ber, $-z$, , $е$. around, prep., um (acc.); $a d v$., berum', umber'.

arrive, an'fommen, fam an, ijt an= gefommen.

as, sub. conj., (past time) alz; (cause) ba; - if, alz $\breve{b} \mathfrak{b}$, alz wenn; - small as, fo flein wie. ashamed, to be -, fid) juämen (of, gen.).

ask, (question) fragen; (beg, ask for) bitten, bat, gebeten (for, um, $a c c$.).

at, prep., ăn (dat. and acc.); -

New York, in Nerw Yorf; home, zu Şaufe; - my house, bei mir.

attempt, berjudien. 
attention, to pay -, auf'paijen.

August, YYuguit', ber.

aunt, Tante, bie, $-n$.

away, wĕg, fŏrt.

\section{B}

back, adv., zurücf; at the -, hin= ten; come-, zurituf'tommen, S., i.

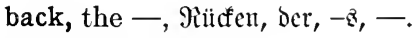
bad, f(d)le(f)t, f(f)limm.

bark, bellen; - at, an'belleil (acc.). be, to - , fein, irr.; how are you, wie geht $\mathrm{ez}$ Slynen; there are, $\mathfrak{e s}$ find; $\mathfrak{e} \mathfrak{B}$ gibt (acc.).

bear, $\mathfrak{B a ̈ r}$, ber, -cen, -ent.

beat, faflagen, fod lug, gej(f)lagen, er jd)lägt.

[ị()ön.

beautiful, fujön; very -, wunder= because, sub. conj., weil.

become, wēroen, wŭrbe, ijt gewŏrben, cr wirb.

bed, Bett, baz, $-\mathfrak{c} z,-e n$.

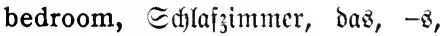

before, prep., vŏr (dat. and acc.); sub. conj., elhe, bevōr'.

beg, (for) bitten, bat, gebeten (um, $a c c$ ).

beggar, Bettler, ber, $-\mathbb{s},-$.

begin, an'fangen, fing ant, angejangen, er füngt an.

behead, enthaupten.

behind, prep., binter (dat. and $a c c$.$) ; adv., hinten.$

believe, glauben (dat. pers.).

bell, ring the - flingeln.

belong, gehören (dat. pers.).

below, unten.

bench, Banf, bic, - bequeath, hinterlaijen, hinterlie $\tilde{\beta}$, hinterlafien, er binterläb̆t.

Berlin, adj., Berlīner.

beside, prep., neben (dat. and acc.).

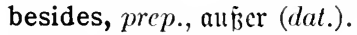

best, beit; adv., am beiten.

better, beijer.

between, prep., zwificen (dat. and acc.).

Bible, $\mathfrak{B i b e l}$, bie, $-\mathfrak{n}$.

big, grō̄i,$\pm \mathrm{er}$.

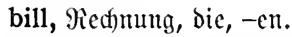

bind, binben, band, gebumben.

bird, $\mathfrak{B o g e l}$, ber, $-\mathbb{z},=$

birth-day, Geburtztāg, der, $-\mathfrak{z},-\mathfrak{c}$.

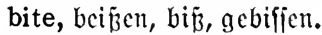

bitterly, bitterlid).

black, f(f)warz.

black-board, Iafel, bie, -it.

bleed, bluten.

bloom, blühen.

blossom, Biüte, bie, $-\mathfrak{n}$.

blush, erröten.

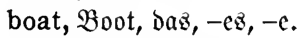

body, Reib, Der, $-e \varepsilon,-e r$.

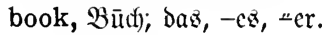

born, gcbo'tren.

both, beibe, bie beioen.

bottom, Boden, ber, $-\mathbb{B},-$.

boy, $\Re n a b e, ~ D e r, ~-n, ~-n$; Sunge, ber,

$-\mathfrak{n},-\mathfrak{n} ; \mathfrak{B u b e}$, ber, $-\mathfrak{n},-\mathfrak{n}$.

bread, $\mathfrak{B r o ̄ t}, \quad b a z,-c z$.

break, brĕ(f)en, brāaf), gebrŏdf)en, er

brif(f)t; - to pieces, jerbre(f)en.

breakfast, to -, irüh'itüufen

(insep.).

breathe, attmen,.

bring, bringen, bradjte, gebradft.

broad, brcit.

brother, Bruder, ber, $-\mathbb{z},{ }^{*}$.

brown, braun. 
bucket, Eimter, Der, $-\mathbb{B},-$

build, bauent.

burn, bremen, bramnte, gebramt; - down, $\mathfrak{a b}$ brenten.

bury, begraben, begrub, begraben, cr begräbt.

busy, bcjuäftigt.

but, co. conj., aber; (strong contrast) aflcin'; (after negative) jon= bern; nothing -, nid)tz alz. buy, faufen.

by, (agent) von (dat.) ; (by means

of) Durd) (acc.); (vicinity) bei (dat.).

\section{C}

cab, Drojd)fe, bie, $-\mathfrak{n}$.

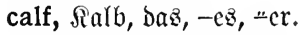

call, rufen, ricf, gerufen; (name)

nemen, namte, genannt; - to, zu' = rufen (dat.).

called, to be -, heiß̄en, hič́, ge= heiźn.

cap, Mü̈ze, bic, $-\mathfrak{n}$.

care, - to, mögen, mod)te, gemodst, er mag.

carriage, Bagen, Der, $-\bar{B},-$.

carry, tragen, trug, getragch, cr trägt.

cart, $\mathfrak{W a g e n}$, Der, $-\bar{z},-$

case, in -, sub. conj., fallz.

cat, Лiaze, bie, -lt.

ceiling, Bimmerbedfe, bic, $-n$.

cent, Eent, Der, $-z$, ,

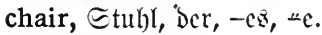

chalk, $\Omega$ reide, Die, -11 .

Charles, Rarl, $-\mathfrak{s}$.

chase, jagen.

cheap, birlig.

check, to -, (trunks, etc.) auf'= geben, gab auf, aufgegeben. cheerful, hciter, fröhliç).

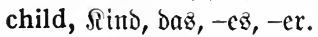

Christian, Ehrift, ocr, $-\mathfrak{e n},-\mathfrak{e n}$.

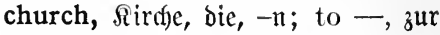

Sirthe; at -, in ber $\Omega$ irdfe.

city, હtabt, bie, «e.

clean, rein.

clever, flug,

clock, $\mathfrak{H}$ hr, bie, $-e n$; at what o'-,

$\mathfrak{u m}$ wie biel $\mathfrak{u h r}$.

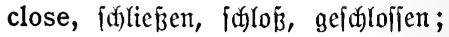

zu'madien.

cloth, $\mathfrak{I} \mathfrak{u}(f), b a z,-e z, \mu e r$.

coal, $\Omega$ ohle, bie, $-\mathfrak{n}$.

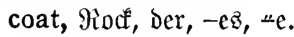

coffee, $\Omega \mathfrak{a} f^{\prime} \mathrm{fec}, \mathrm{der},-\overline{\mathrm{b}}$.

cold, falt,

fror, gefroren; I am cold, midf)

fricrt ez.

color, Farbe, bie, $-\mathfrak{n}$.

come, fommen, fam, ift gefommen;

- from, her'fommen, $\{$.

comfort, tröiten.

commence, an'fangen, fing $\mathfrak{a n}, \mathfrak{a n}=$

gefangen, er fängt an; beginnen, begann, begonnen.

compelled, to be -, müffen, mußite,

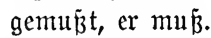

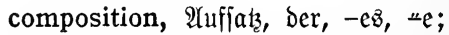

(exercise) $\mathfrak{2} u f \mathfrak{a} a b e$, dic, $-\mathfrak{n}$.

comrade, Ћăměrāo', der, -en, -en. conceited, eingebilbet.

confess, geitehen, geftand, geftanden. conversation, Unterhaltung, die,

-en.

cook, (woman) Röffin, bie, -nen. cool, fiih).

copy, $\mathfrak{a} \mathfrak{b}$ 'ifreiben, fadrieb $\mathfrak{a} \mathfrak{b}, \mathfrak{a b g e}=$

id)ricben.

copy-book, Şeft, Daz, -ez, -e.

correct, riffitig. 
cost, fojten.

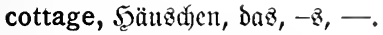

councilman, Miātzhyerr, ber, $-n,-e n$. count, the -, Grāf, ber, $-\mathfrak{e n},-\mathrm{en}$;

-ess, Bräfin, bie, -nen.

count, to - , zählen.

country, $\mathrm{Ranb}, \mathrm{b} a \mathrm{z},-\mathrm{e} z,{ }^{ \pm \mathrm{er}}$; in the -, auj dem Rande.

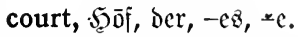

cousin, Better, ber, $-\mathfrak{z},-\mathfrak{n}$.

cover, Decfe, bie, $-\mathrm{n}$.

cow, $\Omega u h$, bie, $\Perp c$.

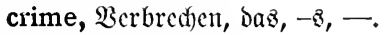

crow, $\Re$ rähc, bic, $-\mathfrak{n}$.

cry, rufen, rief, gerufen; (weep) weinten.

cup, Taffe, bic, $-\mathfrak{n}$.

cupboard, Ed)ranf, ber, $-\mathfrak{e B}, \pm \mathcal{e}$.

cure, furie'ren.

cut, fdneiden, f(d)nitt, gej(f)nitten; down (trees), um'bauen, hieb um, umgchauer.

\section{D}

dance, $\operatorname{tanzen}$.

dark, bunfel; - -er, bunfler.

date, Datum, $D a z,-z$, Daten; what

date is it, ben wiebielten jufreiben wir heute.

daughter, Iodster, bie, " .

day, $\mathfrak{I} \bar{a} g$, ber, $-\mathfrak{c}$,,$-\mathfrak{c}$; next - , den Iāg darauf; - before yesterday, vor'gejtern; - after to-morrow, ï'bermorgen; all -, den ganzen Tāg.

dead, tōt.

dear, teucr, lieb.

decay, zerfallen, zerfiel, ijt zerfallen, er zerfällt.

deceive, hintergehen, hintergung, hintergangen. deep, tief.

describe, bejureiben, bejfurieb, be=

f(f)rieben.

desk, Pitlt, bas, -eß, -c.

die, fterben, itarb, ijt geitorben, er

jtirbt.

difficult, foumēr.

dig, graben, grub, gegraben, er gräbt. diligent, fleiß̧ig.

dirty, f(d) mutzig.

distance, in the -, in ber Ferne.

distant, fern.

do, maduen; tūn, tāt, getān, er tūt.

doctor, Dof'tǒr, ber, $-\bar{z},-\overline{\mathrm{D}}$ 'ren.

dog, Sunt, ber, -ea, -e.

dollar, Dollar', ber, $-\varangle$, -

donkey, Ejel, Dcr, $-\varangle,-$.

door, Titr, bic, -en; next -, neben=

an.

down, linab'; herab'; nieder.

dress, Rleio, daz, -ez, -er.

dress, to -, fleiben; - oneself, fitif)

an'zielen, zog an, angezogen.

dress-maker, Edneiderin, bie, -nen.

drink, trinfen, tranf, getrunfen.

drive, fahren, jubr, ijt gefahren, er fäl)rt.

dry, trodfen.

during, prep., währeno (gen.).

dyer, färber, ber, $-\beta$, ,

\section{E}

eagle, \{toler, bcr, $-\mathbb{z},-$

ear, $\mathfrak{D h r}, \mathrm{daz},-\mathrm{e} B,-\mathrm{en}$.

early, frül); - this morning, heute

frül).

earnestly, crmit.

earth, Erbe, bie, $-n$.

easy, leidft.

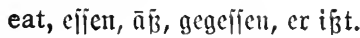


edge, 9iand, ber, $-\mathfrak{c b},{ }^{*} \mathrm{cr}$.

eight, a(d)t.

elder, älter.

eldest, ältẹt.

else, forift.

emperor, Railer, Der, $-\mathfrak{B},-$.

empress, Raifcrin, bie, -nen.

end, Ende, $D a z,-\mathfrak{z},-\mathfrak{n}$.

England, Entglano, Daz, $-z$.

English, englif(d).

Englishman, Entglämber, ber, $-\mathfrak{z},-$ enough, genug'.

enter, herein'treten, trat herein, her=

eingetreten, f.; he -ed the room,

er trat in bas Bimmer herein.

error, Эrrtum, Der, $-z, \mu e r$.

especially, bejon'bers.

Europe, Guro'pa, daz, -ż.

even, fogar'; jelbjt; not -, nidft einmal'; - if, wenn auth.

evening, \{lbend, ber, $-\mathfrak{B},-e$; good

-, guten 2 bend! in the -, abends,

dez 2 bendz, am $\mathfrak{\text { Ubend. }}$

every, jeder.

everybody, jedermann.

everything, allez, jedes.

evil, böв; much -, vicl $\mathfrak{B}$ ö

except, prep., aujer (dat.).

exclaim, aนs'rufen, rief aนz, aนzge=

rufer.

exercise, $\mathfrak{A} u \mathfrak{f g a b e}$, bie, $-\mathfrak{n}$.

exhibition, Pluzitellung, bie, -en.

expect, erwarten.

extinguish, löfduen.

eye, 解e, baz, $-z,-n$.

\section{F}

fairy-tale, Märchen, $\delta a z,,-z$, , -

fall, fallen, fiel, i ît gefallen, er färlt;

- to pieces, zerfallen, $f$. family, Fami'tie, die, $-n$.

far, fern, weit.

far, how -, sub. conj., inmicjern, intwicweit.

farmer, \&anomann, der, $-\mathfrak{z}$, Qand $=$ leute; (peasant) Bauer, ber, -8 , $-\pi$.

fast, fidnell.

father, Bater, Der, $-\mathbb{z}, *$.

fatherland, Batcrland $\delta \mathfrak{d a z},-e \overline{\text {. }}$

fear, fürchten.

feather, Feder, bie, $-\mathfrak{n}$.

fetch, holen.

few, we'nige; a - ein paar, ei'nige.

field, Feld, baz, -ez, -er.

fifteen, fünfzehn.

fifty, fünfizig.

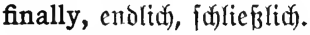

find, finden, fand, gefunden.

fine, fựön.

finished, fertig.

fire, Feuer, $\mathfrak{d a z},-\not B,-$

fire-department, Feuerwehr, bie,-en.

firm, feit.

first, at -, zuērft'.

fit, paffen (dat. of pers.).

five, fünf.

floor, $\mathfrak{F} \bar{u} \mathfrak{\beta} b \bar{b}$ den, ber, $-\mathbb{z}$, *.

flow, fließzen, floz̧, ijt geflofien.

flower, Blume, bie, $-\mathfrak{n}$.

fly, the -, Fliege, bie, -n.

fly, to -, fliegen, flog, geflogen, $f$.

fond, to be - of, gern haben.

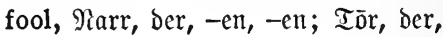
-en, -en.

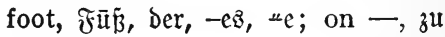
$\mathfrak{F} \overline{\mathfrak{u}} \mathfrak{\beta}$.

for, prep., für (acc.) ; expressed also

by dat. case; - it, ১afür'.

for, co.conj., benn.

forest, Mald, Der, -ez, " 
forget, vergefien, vergā $\bar{b}$, vergefien, er vergifist.

forgive, bergeben, verạāb, vergebell, er vergibt (dat.).

fork, (jabel, bic, -11 .

former, the - jener.

formerly, früher.

fortnight, to-day -, heute iiber vierzehn Iage.

four, bier.

freeze, frieren, fror, gefroren.

fresh, frif(t).

Friday, Freitāg, Der, $-z,-c$.

friend, Freunb, ber, $-\mathfrak{c} b,-\mathfrak{e}$; (female) Freundin; bie, -nen.

friendly, freundlid).

friendship, Freundj(c)aft, bic, -en.

from, vŏn (dat.); - where, wǒher'. front, in - of, vōr (dat. and acc.). full, boll.

\section{G}

gamble, - away, beripielen.

game, Epiel, das, -ca, -c.

garden, Barten, Der, $-z, \ldots$.

gardener, (bärtncr, Der, $-\mathfrak{B},-$

gate, $\mathfrak{T} \overline{\mathrm{D}} \mathrm{r}, \mathrm{b} a \mathrm{z},-\mathfrak{e z},-\mathrm{e}$.

generous, freigebig.

gentleman, Seerr, Der, $-\mathfrak{n},-\mathrm{er}$.

German, (man) Deutjoche, ber, $-n$, -n, adj.-noun.

German, $a d j$., beutjd).

Germany, Deutj(x)'Iand, baz, -ż.

get, (become, grow) wērden, wŭrde, iit getworben; (receive) befom= men, befam, befommen; (arrive) an'fommen, fam an, ijt angefont= men; (fetch), holen; - up, auf'= ftel)en, ftand auf, ijt aufgejtanden. ghost, (beijt, ber, -ez, -er. girl, Mädd)en, baß, $-\mathbb{B},-$ give, geben, gāab, gegeben, er gibt;

(to present) fdenfen. glad, froh; to be -, fid) freuen. gladly, gern. glass, (3) glove, Jjambj(t)uh, ber, $-\mathfrak{z},-e$. go, gehen, ging, iijt gegangen. God, (Sott, Der, -es; gods, (Bötter. golden, golden.

good, gūt; much -, viel (3utez.

granddaughter, Enfelin, Die, -nen.

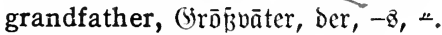
grandparents, Groß̧eltern, bie. grandson, Enffel, bcr, $-z,-$ great, gro $\overline{\bar{B}}, \stackrel{ }{*} \mathrm{er}$.

green, grïl.

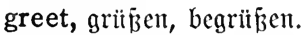
grow (in size), wadjfen, wudfz, ift getwactjien, cr wädsit; (become) werden, wurde, ijt getworden, er twirb.

guess, raten, riet, geraten, er rät.

\section{$\mathrm{H}$}

hail, - from, ftammen aus, dat. hail, hageln.

hair, Scaar, baz, -ca, -ce.

half, halb; - the money, bas halbe

Gelb; - past two, halb brei.

hand, Saand, bie,

handle, hanbhabet, handhabte, ge= hanbhabt.

handsome, hübjd).

happen, gejdeken, gej(d)ah, ijt ge= ideken, ez gejujieht.

happiness, (Slülf́, Daz, $-\mathfrak{e}$.

happy, glï (fflid).

hard, hart, "er; ftarf, "er; (difficult) j(d)wēr.

hard-hearted, hartherzig. 
hare, Scaje, Der, $-\mathfrak{n},-\mathfrak{n}$.

hasten, eilen, fict becilert.

hat, $\mathfrak{S c u} t$, ber, $-\mathfrak{e q}, \pm \mathrm{c}$.

have, haben, irr.; - something

done, etwas mactien lafien, s'.; -

to, (must) müffien, irr.

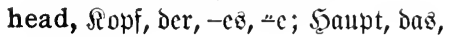
-ez, "

hear, hörell.

heart, $\mathfrak{S e r}_{z}, \mathfrak{D a z}^{2},-\mathfrak{e n z},-e n$; by -, aus'wentig.

heavy, f(c)wer.

help, helfen, half, geholfen, er hilft; (pers. dat.).

her, pron. acc., fie; dat., ihr.

her, poss. adj., ihrr; poss. pron., ihrer, Der ihre.

here, hier; come -, fommelt Eic her!

hero, Selo, der, -en, -en.

high, hōd); -er, höher; -est, hödfft ; $(a d v$.) am hödjiten.

hill, Berg, Der, -ez, -e.

his, poss. adj., fein; poss. pron:, feiner, ber feine, ber feinige.

hold, halten, hielt, gchalten, er hält;

- fast, feit'balten; - up, em= por'balten.

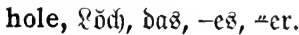

home, to go -, nad) Scaule gehen; at -, 孔u Sauje.

honest, brāon, ehrliç.

hope, hoffen; it is to be hoped, hof '= fentlicif.

horse, $\mathfrak{B j e ̄ r d}, ~ d a z,-c z,-c$.

hotel, Şotel', Daz, $-\mathbb{B},-\beta$.

hour, Etunde, bie, $-n$.

house, Şaus, daz, -cz, ״er.

house-door, Şauztür, bie, -en.

how, mie.

howl, heulen. hundred, (a) hunbert; the -, bas Sunbert, $-\bar{z},-e$.

hungry, hungrig .

hunt, jagen.

hurry, eilen, fidf beeilen.

hurt, weh tun, tat weh, weh getan;

irr. (dat. pers.).

husband, Mann, ber, -ez, ״er.

\section{I}

if, sub. conj., wenn; (whether) ŏb. ill, franf.

illness, $\Omega$ ranflyeit, bie, $-\mathfrak{c n}$.

imagine, fidf) (dat.) ein'bilden.

in, prep., in (dat. and acc.) ; adv., hinein', herein'.

industrious, fleiß̧ig.

inhabit, bewohnen.

inhabitant, Bewohner, Der, $-8,-$;

Ein'wohner, ber, $-\mathfrak{z},-$.

inhabited, betwohnt.

inherit, erben.

$[$ ber, $-\mathfrak{n} z,-n$.

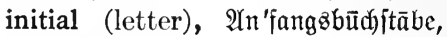
ink, Tinte, bie, $-\mathfrak{n}$.

inquire, fich erfundigen (after, nad). inspect, bejehen, bejah, bejehen.

instead of, prep., ftatt, anitatt

(gen.).

intend to, wollen, irr.

intention, $\mathfrak{Y} \mathfrak{b} f \mathfrak{i d}$ t, die, -en.

interesting, intcrefiant'.

into, prep., in (acc.).

it, eB.

its, poss. adj., fein.

Jack, Sanz.

January, Эă'nuār, ber, $-в$, $-e$.

joy, Freubc, bie, $-\mathfrak{n}$; for - , vor Freude. 


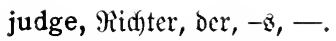

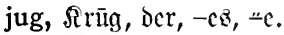

July, $\Im u^{\prime} f i$, Dcr, $-\mathfrak{z},-\mathfrak{z}$.

jump, fpringen, fprang, ift geipruu=

gen.

just, $a d v$., eben; - as big as, cbenio gró̉ wie.

\section{K}

keep, behalten, bchiclt, bchalten, er bchält.

kill, töten, tot'f(d)lagen, fơlug tot, totgeid)lagen, cr jod)lägt tot.

kind, $\mathfrak{A r t}$, bic, $-\mathfrak{c n}$; what - of a man, waв für cin Mann.

kind-hearted, gutherzig.

king, $\Omega$ önig, Der, $-\mathfrak{z},-e$.

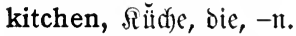

knife, Mefjer, daz, $-\not$, , .

knock, flopfen (at, an, acc.) ; there is a-, ez flopit.

know, (object a noun) fenuen, fannte, gefannt; (object a clause) wifjen, wuß̄te, gewuj̄at, er weiß̄; - by heart, auzmendig wifjen.

\section{L}

lack, felhlen; I - money, mir fehlt (iclo.

lady, Dame, bic, -n.

lake, $\bigodot_{c c}$, ber, $-\boldsymbol{B},-n$.

lamb, $\mathfrak{R a m m}, \mathrm{daz},-\mathfrak{e z},{ }^{\circ} \mathrm{cr}$.

lame, Iahm.

lamp, Rampe, bic, $-n$.

land, Rand, bas, -ed,

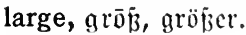

last, adj., letzt; - night, geitern nad)t, geitern abend; at -, endidid, f(d)ließ̄lid), zuletzit. late, ipät; (deceased) jelig, ver= itorben.

later, - on, fpäter.

latter, the -, biejcr.

laugh, lădjen.

lay, legen; - down, hin'legen.

lazy, träge, faul.

lead, fiihren.

learn, lernen.

leg, Bcin, daz, $-e z,-e$.

lend, leiken, lieh, geliehen.

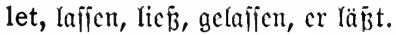

letter, Bricf, bcr, $-\mathfrak{c}$,,$-\mathfrak{c}$; (of the

alphabet) $\mathfrak{B} \bar{u}()^{\prime}$ 'itābc, Der, $-n \bar{s},-n$.

lie, licgen, lag, gelegen; - down, fid bin'legen.

lie (tell a lie), lügen, log, gelogen.

life $R e b e n, b a z,-z,-$

lift, heben, hob, gehoben; - up, auf'beben.

light, \&i(j)t, $d a z,-e z z,-e r$.

lighten, blitzen.

like, to -, mögen, irr.; (fond of)

gern haben; I should-, id mödte.

limp, binfen.

listen, 孔ł'hören.

little, (of size) flcin; (of quantity) wenig.

live, leben; (dwell) wohnen.

local, hicitig.

long, lang,

for a - time, lange, lange Zeit.

look, - at, ăn'fehen, fah an, ange=

jeben; - out, hinaus'ichen, her =

auz'fehen; - down, himu'ter=

fehen; (appear) aแz'íhen.

look for, futfen.

lose, verlieren, berlor, verloren.

loud, laut; -er, lauter.

loudest, $a d v$, am lautiten.

love, lieben. 
low, nicbrig.

luck, SGliidf, baz, $-\mathfrak{c}$.

\section{M}

magnificent, präd)tig.

make, madyen; (cause) Iafien, liȩ́, gelajlen, er läßst.

man, Mann, ber, -ez, " general sense) Menich), ber, -en, -en.

manner, (way) $\mathfrak{B e i f e}$, bie, $-\mathfrak{n}$; in this -, auf bicie Weife; in the best -, aufz beite.

many, viele; - a, mantider.

March, März, ber, -en, -e.

Mark, Marf, bie, - (1 mark = 24 cents); five - s, fünf Marf.

Market-street, Marftjtrá̉e, bie, $-\mathfrak{n}$.

married, verkei'ratet; to get -

(iic) verbei'raten.

marry, hei'raten, insep.

mast, Majt, ber, $-\mathfrak{e z},-\mathrm{en}$.

master, Serr, ber, $-\mathfrak{n}$, - en.

matter, Eăd exe, bie, $-\mathfrak{n}$; what is the

- with you, waz fehlt bir?

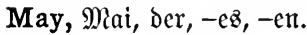

may, (to be allowed) oürfen, irr.;

(possibility) mögen, irr.

meat, Fleifd), baz, -ca.

meet, treffen, traf, getroffen, cr trifft;

(by chance) begeg'nen, f. (dat.);

run to -, entge'genlaufen, S., f.

merry, lujtig.

milk, Mil(t), bie.

million, Mitlliōn', bie, -cn.

mine, bcr, bic, daz meine.

minute, Minu'te, bie, $-\mathfrak{n}$.

Miss, Fräulein, $\mathfrak{d} \mathfrak{a},-\mathfrak{B},-$

moment, 䊗genblidf, Der, $-\mathfrak{z},-e$.
Monday, Mōntāg, bcr, $-\mathfrak{z},-\mathfrak{c}$.

money, Gelb, baz, -ez, -er.

month, Miōnăt, ber, $-\bar{z},-e$.

more, mehr.

morning, Morgen, Der, $-\bar{z},-$; good

一, guten Morgen! in the -,

morgenz, am Morgen.

most, meijt; $a d v$., am meiften.

mostly, meijtenz.

mother, Mutter, bie, «.

mount, jteigen, jtieg, ijt geitiegen.

mountain, $\mathfrak{B} \mathrm{crg}$, Der, $-\mathrm{e} \bar{B},-\mathrm{e} ;-\mathrm{s}$,

(bebirge, $\mathfrak{d a z},-\bar{z},-$

Mr., Seerr, Der, $-\mathfrak{n},-\mathfrak{e n}$.

Mrs., Frau, bie, -en.

much, biel.

Munich, Miündyen, baż, -8 .

must, miiffen, irr.

my, poss. adj., mein; -self, refl., midif.

\section{$\mathrm{N}$}

name, Name, Der, $-n z,-n$; what is your name, wie heí̄en $\mathfrak{S}_{i e}$ ?

name, to -, nemnen, nannte, ge= nannt.

narrow, eng.

naughty, un'ārtig.

near, nahe, comp., näher, närafit ;

-by, nake bei (dat.).

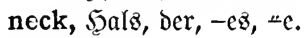

need, braudien.

neighbor, $\mathfrak{i a ̆ d} b \mathfrak{b a ̄ r}$, ber, $-\mathfrak{b},-\mathfrak{l}$.

never, niemalz.

new, net.

newspaper, Zcitung, bie, -en.

next, adj., nächjt; - to, neben (dat.

and acc.); - door, nebenan.

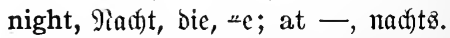

nightingale, Nacif'tigall, bie, -en.

nine, neun. 
no, adv., nein; adj., fcin; - one, teiner.

nobody, niemand.

noise, Rärm, Der, $-z$.

not, nicht; - at all, gar ni(f)t.

nothing, ni(đ)tz; - but, nid)tร alz.

now, jetzt, nun.

number, Pummer, bie, $-\mathfrak{n}$.

\section{O}

o'clock, at three -, um orei $\mathfrak{H h r}$. of, vŏn (dat.); or gen. case without prep.

off, $\breve{a} \mathfrak{b}, \mathfrak{h i n a b} \mathfrak{b}^{\prime}, \mathfrak{h e r a b} \mathfrak{b}^{\prime}$.

often, oft, $* \mathrm{er}$.

oh! act)!

old, alt, -er, älter.

on, prep. (upon) auf (dat. and $a c c$.) ; (against, alongside of) an (dat. and acc.).

once, (numeral) ein'mal; (indef.), einmal', māl; at -, joglcicts'. one, (people, they) măn; (numeral) adj., ein; pron., einer ; cins. only, (adv.) nür; ērit; (adj.) cinzig. onto, auf (acc.).

open, auf'madyen, öffnen.

open, adj., offen; (prefix) auf.

or, ober; either ... or, entwe'ber... oder.

order, to -, befeblen, befahl, $\mathfrak{b e}=$

fohlen, er befichlt (dat.).

order, in - to, um . . . z $u$; in -

that, sub. conj., bămit', jo ba $\tilde{\beta}$, ban.

other, adj., ander; (addlition) nŏd) cin.

ought, I - , id) follte; I - to have, idf) bätte follen.

our, unjer. ours, unier, ber unjere, ber ımirige. out of, (prep.) aนz (dat.); to go -

aus'gehen, ging auz, ijt ausgegan= outside, $(a d v$.) branßzen.

[gen. over, prep., ïber (dat. and acc.).

owner, Befitzer, ber, $-z,-$

ox, $\mathfrak{i}(\mathfrak{B}$, ber, $-\mathrm{en},-\mathrm{en}$.

\section{$\mathbf{P}$}

pain, Schmerz, ber, $-e n z,-e n$.

paint, malen; an'itreichen, ftrich an, angeitricten.

painter, Maler, ber, - - , ; (wo-

man) Malerin, bie, - nen.

painting, (ङemärlde, daz, $-\bar{z},-$.

paper, 'Păpier', baz, $-\mathbb{z},-c$.

parents, Eltern, Die.

Paris, Pariz'.

part, take -, teil'nehmen, nal)m teil, teilgenommen, er nimmt teil. participate, teil'nehmen, $S$. , (in, an, dat.).

past, $a d v$., borbei'; half - two, halb orei; five minutes - two, fümf Mimuten nadi) zmei.

pastor, $\mathfrak{B a}$ 'it path, $\mathfrak{E} \bar{e} \mathfrak{g}$, ber, $-\mathfrak{e} z,-e$.

pay, bezallen.

peace, Fricde, bcr, $-n z,-11$.

pear, Birme, bie, $-n$.

pear-tree, Birnbaum, ber, $-\mathrm{s},-\ddot{e}$.

peasant, Bauer, Der, $-\mathfrak{z},-11$.

pen, Feder, bic, $-\mathfrak{n}$.

pencil, Bleijtift, Der, $-\mathfrak{z},-\mathfrak{e}$.

people, Seute, dic; man; (nation)

Solf, daz, $-\mathfrak{c} z,-\ddot{e r}$.

perhaps, vielleid)t'.

peruse, - hastily, bur(f)lau'fen, burd)lief, Durct)(aufen, $\mathfrak{c r}$ bur(t)= läuft. 
pfennig, $\mathfrak{B f e n t i g}$, ber, $-\mathfrak{z},-c$; five pfennigs, fünf $\mathfrak{B f e n n i g . ~}$

physician, $\mathfrak{A} r_{z} t, \delta e r,-e z,-e c$. pick, pflüffen.

picture, Bild, daz, -ez, -er.

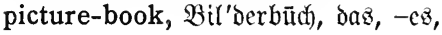
\#cr.

piece, Stücf, baz, $-c z,-c$; - of

bread, Etülf Brot.

pig, Edfwein, bas, $-e z,-c$.

pine-forest, Ian'nentwald, der, $-\mathfrak{c}$, «cr.

pine-tree, Tanne, bic, $-\mathfrak{n}$.

pink, Sielfe, bic, $-\mathfrak{n}$.

pitcher, $\Re r u \bar{g}$, bcr, $-\mathfrak{c}$,,$-c$.

place, $\subseteq \mathrm{rt}, \mathrm{Dcr},-\mathfrak{c z}, \pm \mathrm{cr}$; (room)

Platz, ber, $-e z,-e c$.

place, to -, ficllen.

plant, pflanzen.

play, fpiclen.

playground, Spielplatz, ber, $-e z, \pm e$. please, to -, gefallen, gefiel, ge=

fallen, er gefüllt (dat. pers.).

please, (polite request) bitte (abbr.

of id bitte).

pocket, Iaj(b), bie, $-\mathfrak{n}$.

poet, Didyter, Der, $-\mathfrak{z},-$

polite, höfflida).

poor, arm, - er.

pork, Ed)weinefleif(t), Das, $-c 8$.

postal-card, Poitfarte, bie, - $\mathrm{t}$.

pour, giсß̋en, goß̉, gegoffen.

praise, loben.

present, Gefdjenf, daz, $-e z,-c$;

make a - , fdenten.

present (adj.), jetzig.

president, 'srắfitiont', Dcr, -en, -êt. pretend, wollen; he $-\mathrm{s}$ to be rich, er will reid) fein.

pretty, f(c)ön; - much, zicmlicf) vicl. price, $\mathfrak{B r c i z}$, ber, -ça, -e.

prince, Fürit, bcr, $-\mathfrak{e n},-\mathfrak{e n}$; $\mathfrak{B r i n} z$,

ber, $-e n,-e n$

princess, Füritin, bie, -nen; Prin=

zef'fin, bie -nen.

proverb, Epridfowort, $\delta a z,-e z,-\mu e r$. punish, ftrafer.

purse, $\mathfrak{B o ̈ r}$ re, bie, -n.

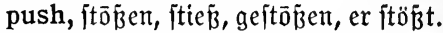
put, itellen; fetzen; (stick) ftecfen;

- on, auf'fetzen; (clothes), an'= zieken, zog an, angezogen.

\section{Q}

quarter, Biertel, $\delta a z,-\not{z},-;-$

past three, ein $\mathfrak{B i e r t e l}$ vier; to four, brei $\mathfrak{B i e r t e l}$ vier. queen, $\Re \ddot{o}$ 'nigin, bie, -nen.

question, Frage, bie, $-\mathfrak{n}$; ask a eine Frage ftellen. question, to -, fragen. quickly, fánell, rajád. quiet, rufig; jtill. quite, găız.

$\mathbf{R}$

railroad, Ei'fenbahn, bie, -en.

rain, গegen, Der, $-\boldsymbol{B}$.

rain, to -, regnen.

rare, felten.

rather, lieber; (somewhat) etwas. read, lejen, las, gelejen, cr liejt. receive, erhal'ten, erhielt, crhalten,

er crhält; befommen, befām, be= fommen; (welcome) empfangen, empfing, cmpfangen, er empfängt. reception-room, Empfang'zimmer, Daz, -8, ,

recognize, erfennen, crfannte, er= fannt. 
refuse, $\mathfrak{a} \mathfrak{b}^{\prime} \mathfrak{w}$ cijen, wick $\mathfrak{a} \mathfrak{b}, \mathfrak{a b g c t w i c}=$ fen; fid) weigern.

rejoice; erfreuen; fidf freuen.

relation, Berwand'te, Dcr, $-n,-n$ (adj.-noun).

relative, Berwand'te, Der, $-\mathfrak{n},-n$ (adj.-noun).

remain, bleiben, blicb, ijt gcblieben. remember, fiti) erin'nern (gen.); me to him, grüßzen Sic ifn von mir.

remind, crin'nern.

rent, Miete, bic, $-\pi$.

rent, to -, (hire) micten; (let) vermicterl.

repeat, wicierho'lcn.

resist, widerjte'hen, wideritand, wi= beritanden (dat.).

rich, reid).

riches, Mei(f)tūm, Dcr, $-\bar{B},{ }^{2} \mathrm{cr}$.

ride, (in a vehicle) fah)ren, $f u f(f) r, i f t$ gefahren, cr fährt; (on an animal) reiten, ritt, ijt geritten.

right, redft; you are -, Eie habcu redi)t.

ring, - the bell, flingeln.

ripe, reif.

rise, ftcigen, fticg, ijt gejtiegen, (of the sun) auf' $\mathfrak{e}$ hen, $S$. f.

roll, roflen.

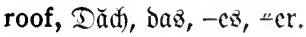

room, Bimmer, baz, $-z,-$

rope, @tricf, Dcr, $-\mathfrak{c B},-\mathfrak{c}$.

rose, $\Re$ oje, bie, $-n$.

rough, (of water) bctuēgt.

run, laufen, lief, ift gelauffen, cr lüuff ; rennen, rannte, iit gerannt; after, nad)' 'laufer (dal.), s. f.; along, her and hin' 'laufen, $S$. $\uparrow$.

\section{$\mathrm{S}$}

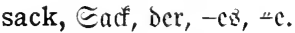

sad, traurig.

sake, for my -, mei'netwegen, mci'netbalben.

same, the -, Dericlbc.

satisfied, zufric'sen.

Saturday, ভomu'abent, bcr, $-\mathbb{\varepsilon},-\mathfrak{c}$;

๔ămı̇tāạ, ocr, $-\mathfrak{z},-e$.

saving, fpārjaut.

say, fagen.

scholar, E(f)ülcr, ber, $-8,-$; (fe-

male) E(t)ülerin, bic, -nen.

school, $\Xi_{d} u l c, b i c,-n$; at -, in bcr

E(f)ule.

school-mate, 巨র(f)ultfămĕrāo', ১cr, $-\mathrm{en},-\mathrm{cn}$.

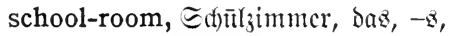

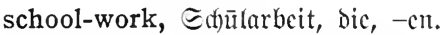
scold, fiffelten, f(f)alt, geffolten, cr id)ilt.

scratch, fratzen.

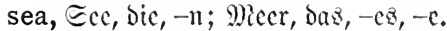
sea-shore, to go to the -, an bic

Ece gehent.

see, f(chen, fah, gejchen, cr jicht.

seek, fituficu.

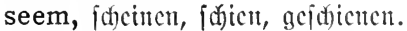

sell, berfaufen.

send, fenocit, fantote, geianot; fidicfent. serious, crnit.

set, (of the sun, etc.) mut'tergehen, ging tuter, ift int'tergegangen;

(place) jezzert.

seven, ficben.

shade, to -, beiffatten.

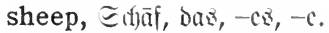

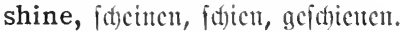

ship, Éctifi, baz, $-\mathfrak{c} \&,-c$. 
shoe, $\mathscr{S}(\mathfrak{f})$ h), Der, $-\mathfrak{e},-\mathfrak{e}$.

shop, Raben, Der, -8 ,.

short, furz,

should, I -, (ought) iff follte;

(cond.) idf müroce.

shout, Yaut rufen, rief, gerufen; jafreien, fdrie, geidrien.

show, zeigen.

shut, 孔u, $a d v$.

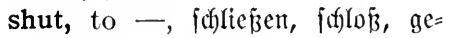

fălŏfien; zu'madyen.

sick, franf, "er; un'mohl.

silent, to be -, f(f)weigen, f(f)mieg, hat gefdrwiegen.

since, prep., feit (dat.); sub. conj.,

feit, feitoem; (reason) ba.

sing, fingen, fantg, gejungen.

sister, $\mathfrak{G}_{(f)}$ ejter, bie, $-\mathfrak{n}$.

sit, fitzen, $\{\bar{a} \tilde{\beta}$, gefeffen; - down, fitc) hin'jetzen.

six, fectaz.

sky, Seimmel, ber, -8, ,

slate, $\mathfrak{T a f e l}$, bie, $-\mathfrak{n}$.

slay, erifflagen, crifflug, erifdlagen, er eridulägt.

sleep, f(d)lafen, f(d)licf, gefdilafen, er f(c)läft.

slow, -ly, langianm; the clock is -, die Uhr geht nadf.

small, flein.

smoke, raudfen.

so, fo, aljo.

sold, verfauft.

some, -what, -thing, etwaz.

song, Ried, baz, $-\mathrm{ez},-\mathrm{er}$.

song-book, Ricberbu(f), daz, $-\mathfrak{c}$, 上er.

soon, bald.

sorry, I am -, es tut mir leib; I am

- for her, fie tut mir leio.

sound, flingen, flang, geflungen.
South, Eitien, Der, -8 .

South Germany, 厄übdeutfdiland, da $\bar{a},-\bar{z}$.

speak, iprěct)en, fprā(t), geiprŏdy)en, cr iprict)t.

spectacles, Brille, bie, $-\mathfrak{n}$.

speech, Rede, bie, $-n$.

spend, aนz'geben, gab atz, auzgege= ben, er gibt auz.

spirit, beift, ber, $-\mathrm{e} z,-\mathrm{er}$.

spite, in - of, prep., trotz (gen.).

spoon, Röffel, ber, $-\mathbb{Z},-$.

sprain, berrenfen.

Igen.

spring, ipringen, iprang, ift geiprun=

stable, Stall, der, -ca, ״e.

stairs, Treppen, bie, $-\mathfrak{n}$; fall down

-, bie Treppen hinun'terfallen,

S., f.; (downstairs) unten.

stamp, Briefmarfe, bie, $-\mathfrak{n}$.

stand, itehen, jtand, geftanden; -

up, auf'itehen, f.

star, Etern, Der, -ez, -e.

state, Etaat, Der, -ç, -en.

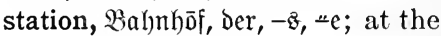

一, am $\mathfrak{B a h n h b o ̄ f e . ~}$

stay, bleiben, blieb, ift geblieben; -

at home, heim'bleiben, zu Saaule

bleiben.

steal, itehlen, itahl, geftohlen, cr

itieblt.

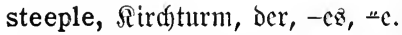

step, Edfritt, ber, $-\mathfrak{c}$, $-\mathfrak{c}$; with

quick -, fdnellen $\subseteq$ d)rittes.

step, to - , treten, trat, ift getreten,

er tritt; - in, ein'treten, $f$; her $=$ ein'treten, $f$.

stick, 巨todf, der, -ę, $\Perp$ e. [ben. stick, to -, ftecfen; (cleave) $\mathfrak{f l e}=$ still, $a d j .$, ftill, ruhig; adv., (time) noch); (after all) ood).

stocking, 巨trumpf, ber, $-e z$, 
stone, Stein, dcr, -ca, $-\mathrm{e}$.

store, Raden, Der, $-\mathfrak{z}, \pm$.

story, (Beidfidf)'te, bie, $-n$.

stove, $\overline{\mathrm{D}} \mathrm{fen}, \mathrm{Der},-\bar{z}, .$.

strange, fremb.

stranger, Frembe, ber, $-n,-n$

(adj.-noun).

street, Strā $\mathfrak{B} e$, bie, $-\mathfrak{n}$.

strike, fod)lagen, fodflug, gejoldagen, er

j(f)lägt.

strong, ftarf; -er, ftärfer.

student, ভtudent', ber, $-\mathfrak{e n},-\mathrm{en}$;

(female) Etuden'tin, bie, -nen.

study, ftubie'ren; lernen.

stupid, bumm, $=$ er.

succeed, gelingen, gelang, ift gelun=

gen (imp. dat.); he $-\mathrm{s}$, er gelingt

ihm.

such, foldf; - a, ein foldfer.

summer, 巨ommer, ber, $-z,-$.

sun, Eonne, bic, -1 .

Sunday, ๔ŏnntāan, der, $-\mathfrak{a},-e$; on

—, am Eŏnntāge.

sunshine, Eon'nenffrein, ber, -z̧.

swallow, Eifmalbe, die, -n.

swim, f(f)wimuten, fif wamm, ift $\mathfrak{g e}=$

(d) momment.

swimming, the -, baz ๔(f)rimmen, $-\mathfrak{B}$.

\section{$\mathrm{T}$}

table, Iifd), ber, $-c z,-e$.

tailor, Єrfncider, ber, $-\mathbb{z},-$

take, nehmen, nahm, genommen, cr

nimmt; - off, ab'uthmen; (pull off), aแs'zichen, $3 \bar{v} \mathfrak{g}$ aแz, aแzge $=$ zōgen.

talk, fprětf)en, fprāiff), gefprŏ(f)en, er ipridyt.

tea, Icc, der, $-\mathfrak{z}$.

teach, lehren. teacher, $\mathfrak{s c h r e r}$, ocr, $-\mathfrak{z},-$; (fe-

male) \&chrerin, bie, -nen.

tear, zerrei $\bar{\beta} e n, z$ crri $\bar{\beta}, z$ erriffen. telephone, telephonic'ren.

telephone number, Tēlephōn'num= mer, bie, $-n$.

tell, fagen; (narrate) erzäblen.

temptation, Berfucfung, bie, -en.

ten, zchn.

tend, hüten.

than, als.

thank, banfen (dat. pers.); - you, banfe.

that, (dem.) jelter, bēr; (rel.) Der, weld)er; sub. conj., ba $\mathfrak{B}$; so -, fo Da $\mathfrak{B}$.

their, poss. adj., inr.

them, acc., fie; dat., ifnen.

then, dann (time); aljo, jo.

there, $\delta \bar{a}$.

therefore, barum', baher', alfo.

therein, Darin'.

thick, bidf.

thief, Dieb, Der, $-\mathfrak{e} z,-e$.

thin, Dünn.

thing, ๔ădfe, bie, $-\mathfrak{n}$; Ding, baż, $-c z$ $-e$.

think, benfen, badfte, gebad)t (of, an, $a c c$.).

thirsty, Duritig.

this, biejer; bicz.

thought, (Sedan'fe, Der, $-\mathfrak{n z},-n$ (of, an, $a c c$.).

thousand, Iaujent, ber, $-\mathfrak{z},-\mathfrak{c}$.

three, orei.

through, prep., burd) (acc.).

throw, werfen, iwarf, getworfen, er wirft.

thunder, to -, Domtern.

thunder-storm, (Gewit'ter, baz, -8 , 
Thursday, Don'nerítāg, Der, $-\mathfrak{z},-e$. thus, $[\overline{0}$.

ticket, $\mathfrak{B}$ lllet $^{\prime}, b^{\prime} \mathfrak{z},-\mathfrak{z},-\mathfrak{z}$; railroad-, Fahrfarte, bie, -n.

tie, binden, band, gebunden.

till, prep., biz (acc.).

time, ßeit, bie, -en; (occasion) Māl, bas, $-\bar{z},-e$; three $-\mathrm{s}$, brei $=$ māal; at that -, bamālzz; in -, zeitig.

time-table, Fahrplān, Der, -ż, "e. tired, mitice.

to, prep., zu (dat.); nach) (dat.); an (acc.); auf (acc.).

to-day, heute; to-day's, heutig, adj.;

a week from -, heute über adft

Iage.

together, zufam'men.

to-morrow, morgen; day after -

$\ddot{u}$ 'bermorgen.

too, zu.

towards, prep., gegen (acc.); nach

(dat.) ; adv., entgegen; he came

- me, er fam auf midg zu.

tower, I I urm, Der, -ę, - -e.

town, ভtabt, bie,

town-hall, Rāthauz, Daz, -ez,

train, $\overline{3} \overline{\mathrm{u}} \mathrm{g}, \mathrm{ber},-\mathrm{es},-\mathrm{e}$.

trample on, zertre'ten, zertrat, zer=

treten, cr zertritt.

translate, ïberjekz' $\mathrm{en}$.

travel, reifen, f.; fahren, fuhr, ijt ge=

fahbren, er fäbrt.

traveler, Rei'jende, Der, $-\mathfrak{n},-\mathfrak{n}$

(adj.-noun).

tree, Baum, Der, $-\mathfrak{c}$,

trick, (treidf, Der, -ez, -e.

true, wahr.

trunk, Soffer, Der, $-B,-$

truth, $\mathfrak{W a h r b e i t , ~ b i e , ~ - e r . ~}$

try, veriūden.
Tuesday, Dienjtāăg, ber, $-\bar{z},-e$. turn, wenden, wanbte, getwandt; round, um'menden.

twelve, zmölf.

twenty, zwanzig.

twice, 孔meimāl; - as large as, zmei=

māl jo gró̉ mie.

two, zwei.

\section{U}

umbrella, Re'genidjirm, ber, $-\bar{z},-e$. uncle, Snfel, Der, $-\mathfrak{z},-$.

under, prep., unter (dat. and acc.). understand, veritehen, veritano, veritanden.

unhappy, un'glüufflid).

university, Univerjität', bie, -en.

unluckily, unglïuflidferweife.

unripe, un'reif.

until, sub. conj., biż.

up, herauf', hinauf'; empor'; - and

down, auj und nieber; (back and

forth), hin und her.

upon, prep., auf (dat. and acc.).

us, unz (dat. and acc.).

use, gebraudien; braudien.

\section{V}

valley, Tāl, daż, $-e \bar{z}, \pm e r$.

very, fehr, gāar.

village, Dorf, $\delta a z,,-e z,,-e r$.

visit, $\mathfrak{B c}$ (jud), Der, $-\mathbb{z},-e$; pay a -

einen $\mathfrak{B}$ ejud) madjen.

visit, to -, bejüdjen.

voice, Etimme, bie, $-\mathfrak{n}$.

vow, geloben.

\section{W}

wait, marten (for, auf, $a c c$.). waiter, Iellner, Der, $-\bar{z},-$. walk, gehen, ging, ijt gegangen. 
wall, (inside) Want, bie, ״e; (outside) Mauer, bie, - $l 1$.

want, - to, wollen, irr.; I want to, idi) will.

warm, warm, "er.

wash, the -, $\mathfrak{i g a j}$ dfe, bie.

wash, to -, wajden, muj(f), gewa= fduen, er mäf(d)t.

water, $\mathfrak{W a f f e r , ~ d a z , ~}-z,-$

way, $\mathfrak{W} \overline{\mathfrak{c}} \mathrm{g}$, ber, $-\mathfrak{e}$,,$-\mathfrak{e}$; he went on

his -, er ging feines : 2 egez.

weak \{(f)ră(f), ״er.

weather, $\mathfrak{W e t t e r}, \mathrm{Da} s,-\mathbb{8}$.

Wednesday, Mittmŏd), der, $-\mathfrak{B},-\mathfrak{e}$.

weep, weincr.

[nūıt.

well, wohli ; gūt; (exclamation)

West, Weften, Der, $-\mathfrak{s}$.

wet, nă $\mathfrak{3}$, ״cr.

what, เwăs, wel(t)er.

when, (interrogative) wann; sub.

conj. (of past time) als; (of

future time) wertr.

whenever, sub. conj., went.

where, wō; (whither) mŏhin'.

whether, sub. conj., ŏb.

[dicer.

which, weld)er; (relative) Der, wel= while, sub. conj., währento, inbēm'. white, twei $\mathfrak{\beta}$.

whither, wŏhin'; too . . . bin.

who, (interrogative) wer; (relat.)

der, weldfer.

whole, ganz.

whom, (interrogative) dat., wem, acc., well; (relat.) Dem, Den.

whose, (interrogative) weffen ;

(relat.) Deffen, Deren.

why, wărŭm'.

wicked, böz.

wife, Frau, bie, -en.

will, wollen, irr. ; I -, idy will; (in

future tenses) id twerde.
William, $\mathfrak{B i l f h e l m , ~ D e r , ~}-\bar{z}$.

wind, $\mathfrak{Y i n t}$, Der, $-\mathfrak{e} B,-\mathfrak{e}$.

window, Fenjter, bas, $-z,-$

window-sill, Fen'iterbanf, bie, "e. with, prep., mit (dat.) ; along mit.

without, prep., ohne (acc.).

woman, Frau, bie, -en.

wood, Wald, ber, $-\mathfrak{e z},-\operatorname{er}$.

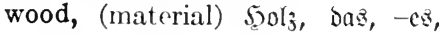
-er.

word, $\mathfrak{B o r t}, \mathfrak{D a s},-\mathfrak{e} ;$; disconnected

words, $\mathfrak{\text { Sörter; }}$ connected words,

Borte.

work, 2lrbeit, bic, -en; (of an

author) Werf, baz, $-\mathfrak{e z},-e$.

work, to -, arbeiten.

worm, $\mathfrak{i B u r m , ~ D e r , ~ - e ̨ , ~ - ~ - e r . ~}$

worse, f(d)limmer.

[wert. worth, wert; - while, ber Mlühe would, (wanted to) wollte; (condit.)

mürbe.

write, f(d)reiben, fdoricb, gejd)rieben

(to, an, acc.) ; - down, auf'= ifrreiben, furieb auf, aufgeidrie= ben.

\section{Y}

yard, $\mathfrak{S} \bar{b} f$, Der, $-\mathfrak{e z}, \pm \mathcal{e}$.

year, $\mathfrak{s a h r}, \mathfrak{b a s},-e z,-e ;-$ of life,

Rébenżahr, daz, -cz, -c.

yes, $j \bar{a}$.

yesterday, geftern; -'s, gejtrig,

adj.; day before -, vor'geitern.

yet, (time) nŏ (f); (emphasis) Dัŏ ;

not -, nǒ(t) ni(t)t.

young, jung, $=\mathrm{er}$.

your, $3 \mathfrak{h r}$, beill, etter.

yours, $\Im$ hrer, Deiner, eurer; ber $\$$ hre,

beine, cure.

yourself, you -, Eic jelbit, bu

jelbjt; refl., ji(d), Did). 


\section{INDEX}

The referenoes are to the paragraphs, sections, notes, Introduction, or Appendix.

$\mathfrak{a b c r}, 40$.

ablaut, 41.

Accent, Introduction, $\mathrm{XV1}$; of verb-prefixes, $47(1), 50(3), 169(2)$.

Accusative, 9 ; of time, 81 ; with prep., 86 ; uses, 183-185, 187(4).

Address, pron. of, 1(2).

Adjectives: declension, 54-60; comparison, 64-67; as adverbs, 54(1); as nouns, 61; pronominal, 27 ; possess., 30 ; as prefixes, 171; derivation, App. G III.

Adverbs: adjectives as - $54(1)$; comparison, 64-67; superlative, 67; position of adv. of time, 26 ; derivation, App. G III.

Agreement: article and noun, 3 ; pron. and noun, $3(2)$; pron. and poss. adj., $30(3)$; relative and antecedent, $100(3)$; verb and subject, 1(1).

all, 62 , note.

alleiil, $40,40(2)$.

Alphabet, Introduction, IX.

als, after adj. or adv., 66 ; conj., 99(1).

aII, 94 .

aIt, prep., 92-93; prefix, 52.

anitatt, 89.

Article, definite: declension, 17; contraction with prep., 94 ; with proper names, $5-6$.

Article, indefinite: declension, 29.

'as', after adj. or adv., 66; conj., 99, 99(5).

'at', equivalents, 93.

aนt, prep., 92-93; prefix, 52 .

aแล, prep., 90; prefix, 52.

$\mathfrak{a} \mathfrak{u} \mathfrak{e} \mathfrak{c}, 90$.

Auxiliaries: use, 48 ; $31-32 ; 123$; paradigms, App. A I.

$\mathfrak{b e}=, 47(3)$.

bei, prep., 90, 90(3).

bcibc, 62 .

bevor, 99 .

'by', equivalents, 90(3), (123)3.

Capitals, use, Introduction, $\mathrm{X}$.

Cardinal Numerals, 173.

Cases, use, 178-187.

-then, 78.

Comma, use, Introduction, XI; 98, note; $100(5)$.

Comparison, adj. and adverbs, 64-67.

Compound Nouns, 20.

Compound Verbs, 47, 50-53, 169-172.

Conditional Clauses, 140, 167-168.

Conditional Mood, 166-168.
Conjunctions, eo-ord., 40; subord., 99.

Consonants, Introduction, XIII-XVI.

Contraction of def. art., 94.

Co-ordinating Conjunctions, 40.

'could', 150.160-162.

ba, sub. conj., 99(5).

$\mathfrak{b a}$, for pron. and demonstrative, 111.

ba $\tilde{k}, 99$; omission, 117.

Dates, 176.

Dative: use, 12, 180-182, 187(3); after "prep., 90, 92; with verbs, 186, App. E.; ethical, 182; possessive, 180; of separation, 181.

Declension: def. art., 17; indef. art., 29; nouns, 74-83, 88; adj., 54-60; adj. nouns, $61(2)$; pron. adj., 27 ; poss. adj., 30 ; pers. pron., 18; rel. pron., 100.

Demonstratives, $109-112$.

bent, $40 ; 40$ (3).

Dependent Clauses, word order, 95-100, 155.

ber, def. art., 3 ; declension, 17.

ber, dem. pron., 109-111.

ber, rel. pron., 100.

berest, 100.

berielbe, 57.

befien, 100.

Dicicr, 27; 110 and 112 .

Diphthongs, Introduction, XIII.

DIt, use 1(2); declension, 18.

Durd), prep. 86; prefix, 169.

Ditrifu, 147-152, 161-162.

c, of dat. sing., 12(1); of nom. pl., 79; of nom. sing., $28,84(3)$; in verbs, $15(1)$.

ch) 99 .

cıit, 29; numeral, $173 a$.

citt words, 29-30; used as adj. or nouns, 63.

cincr, 63(2).

$\mathfrak{e m} \mathfrak{p}=47(3)$.

ent $=, 47(3)$.

$\mathfrak{c r}$, pron., $3(2)$; declension, 18.

$\mathrm{er}$, insep. pref., $47(3)$.

erit, ord. number, 175.

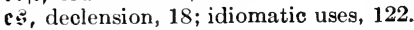

Ethical Dative, 182.

Feminine, nouns, 84 ; App. F II.

'for,' 40(3).

Fractions, 175(2).

fiitr, 86.

Future, 31-32.

Future Passive Participle, 115(2)a. 
$\mathbf{g e}=$, of past part., $23(1), 50(5)$; omission, $47(2), 123 a$; prefix of verb, $47(3)$; prefix of noun, 77 III.

gegen, 86 .

Gender, 3, 2S, 84,82 note, App. I.

Genitive: use, $10 a, 17 s-179,187(2)$; of time, 80 ; with prep., 89 ; with verbs, App. D; adverbial, 17s; partitive, 91, 179.

geru, 64(3).

gibt, es-, $122(1)$.

habcu, as aux., 48; omission, 103; paradigm, App. A I.

halb, 62 ; time, 174 .

ljer, 53 .

hiti, 53 .

hiutcr, prep., 92; prefix, 170(2).

hod), $55(1) c, 64(2)$.

Hortatory Subjunctive, 137.

=icre $u$, verbs in -, 116 .

'if,' $99(4), 140(1-2)$.

iljr, pers. pron., 2, 18; poss. adj., 30 .

Imperative, $34,46,51$.

Impersonal Verbs, 121.

iil, 92 .

Indefinite Article, 29.

indent, 99 .

Indicative Mood, in indirect discourse, $132 a$.

Indirect Discourse, 132, 136.

Infinitive, after verbs, $33,50(4), 87,152$

Inseparable Prefixes, 47, 169-171

Interrogative Pron., 19.

Intransitive Verbs, $48(1) a, 48(2)$.

Inverted Order, 39.

it is $I, 122(2)$.

jeder, $27(1)$.

jencr, 27(1-3), 112.

fitil, 29.

fettrn, 114; use, 113(3).

‡ünnc॥, 147-152, 160-162; App. A VIII.

Iaffet, 164-165.

-leiu, 78.

maı, 125.

maud)er, 27(1).

Measure, expression of, 91 .

utcin, 30,63 .

mit, prep., 90; prefix, 52.

Mixed Declension, of nouns, 88 ; of adj., 59.

Modal Auxiliaries, 147-163, App. A VIII.

Modified Vowels, Introduction. XIIXIII.

mögcn, 147-152, 161-162, App. A VIII.
Mood, Subjunctive, 128-140.

Motion, verbs of,$- 48(2) a$.

miïfïcn, 156-162, App. A VIII.

uad), prep., $90(1)-(2)$; prefix, 52 .

แad)〉cut, $99(7)$.

uäd)ft, $64(2)$.

yiamc, $8 \mathrm{~S}(2)$.

Names, Proper, 10(5)-(6).

ucbeu, 92 .

nid)t, 16.

Nominative, 2, 1S7(1).

Normal Word-Grder, 3 .

Nouns: strong declension, 74-82; weak declension, 83; mixed declension, 88 ; adjectives used as -, 61; compound nouns, 20; of measure, 91 ; gender, 3 , 84, App. F.

Numerals, cardinals, 173; ordinals, 175.

ob, $99(4)$.

obglcid), 99 .

Object, direct, 9; indirect, 12 .

obcr, 40.

'of,' 10(1); omitted, 91 .

olutc, 86 .

Ehr, $88(1)$

'on,' 93.

Optative Subjunctive, 138.

Ordinals, 175 .

Participles: present, 115; past, 23, 25, 43; as nouns, $61(1)-(2)$; as adj., $5 \tilde{5}(1) e$, 115 .

Passive, 123-127.

Past Tense: Indic., 14; of strong verbs, 41 ; uses, 24(2); Subj., 133, 136.

Perfect Tense: 21,42 ; uses 24(1); Subj., $129,136$.

Personal Pronouns: of address, 1(2); declension, 18; word order, 12(3); agreement, $3(2)$; substitutes for,$- 57(1)$, $109(2), 111$.

Pluperfect Tense: Indic., 22, 44; Subj., $134,136$.

Possessive Adjectives, 30 .

Possessive Case, 10.

Possessive Dative, 1S0, 1S7(3).

Possessive Pronouns, 63(3).

Potential Subjunctive, 139.

Predicate Accusative, 185.

Predicate Nominative, 2(1).

Prefixes, insep., 47, 169-172; sep., 50-53, $169-172$.

Prepositions, 85; contractions, 94; with acc., S6; with dat., 90; dat. and acc., 92-93; gen., s9.

Present: Indic., 5; vowel changes of - in 
strong verbs, 45; Subj., formation, 128; use in indir. discourse, 132, 136.

Principal Clause, wort-order, 37, 97-98.

Principal Parts of Verbs, 43.

Pronouns: see under Personal, Possessive, Relative, Demonstrative.

Pronunciation, Introduction, XI-XVI.

Proper names, $10(5)$.

Punctuation, Introduction, X-XI.

Quantity, of vowels and consonants, Introduction, XI-XVI.

Questions, indirect, 132, 136.

Reflexive Pronouns, 119.

Reflexive Verbs, 120.

Relative Clauses, 100-103.

Relative Pronouns, 100-103.

Repetition, of Article, 3(3).

Rivers, gender, App. F IIc.

Script, German, App. H.

icin, 'to be': paradigm, App. A I; verbs conjugated with, 4\$(2); omission, 103.

icit, prep., 90 ; conj., $99(6)$.

feitbe m, $99(6)$.

iclbit, $119(5)$.

Separable Prefixes, 50-53, 169-172.

iid), $119(2-4)$.

Eic, 1(2), 18 .

juldjer, 27(1).

fullet, 156-163; App. A VIII.

jumberu, $40(1)$.

Strong Conjugation, 41-46; list of verbs, App. B, C.; paradigm, App. A III.

Strong Declension, of nouns, 74-82; of adj., 55 .

Subjunctive Mood: formation, 128-130, 133-135; use, 131-132, 136-140.

Subordinate Clauses, 95-98.

Sub. Conj., 99.

Superlative, 64-67.

Syllabication, Introduction, $\mathrm{X}$.

Tense: in indirect discourse, 136; use of past and perfect, 24; use of present, 31(3); future, 31(4); see also under Auxiliaries and under the various tenses.

'than,' after comparatives, 66 .

'that,' how rendered, 27(3), 109.

'there is or are', 122.

Time, acc. of, 81 ; gen. of, 80 ; adv. of, 26; time of day, 174; dates, 176.

'to,' prep., how rendered, $90(2)$; before infinitive, 50(4), 152.

Transposed Order, 96.

trotz, 89 .

ïbcr, prep., 92; prefix, 169. utu, prep., 86 ; prefix, 169 ; with infin., 87.

llulatt: Introduction, XII-XIII; in comparison, 64; in declension, 77-79, 82; in present tense, $45(2)$; in past subj., 133.

แID, 40.

-min, gender of nouns in, 84(1).

ulier, 30.

unter, prep., 92; prefix 52, 169.

ver $=, 47$.

Verbs: alphabetical list of strong and irreg., App. C.; classes of strong, App. B; compound, 47, 50, 53, 169; impers., 121; irreg. weak, 114; paradigms, App., A.; place of, 37,96 ; prin. parts, 43 ; reflex., 120; strong, 41-46; with jein, 48(2). vicl, 64(3).

vou, $90(3)$; with passive, 123(3).

vor, prep., 92 ; prefix, 52 .

Vowels, Introduction, XI-XIII.

wäfreno, prep., 89; conj., 99.

เพaแกเ, $99(3)$.

was, interrog. pron., 19 ; rel. pron., 101(1).

Weak Conjugation, irreg., 114; paradigm, App. A II.

$[56$.

Weak Declension, of nouns, 83; of adj., twege $1,89,118(1) b$.

Weight, expressions of, 91.

weil, 99.

weld $\mathfrak{e r}$, pron. adj., 27(1); rel. pron., 100.

went, $99(4)$.

wer, interrog., 19; rel., 101.

werdel: future, 31-32; condit., 166; passive, 123 ; paradigm, App. A I.

'when,' how rendered, 99(1)-(3).

'whether,' 99(4).

wic, 99 ; with adj., 66.

wicber $=, 170$.

wir, 18.

wificn, 113, 113(3).

twolfet, 156-158, 161-163(2).

$\mathfrak{w v}(\mathbf{r})$, before prep., 102.

Word Formation, App. G.

Word Order: adverbs of time, 26; direct and indirect object, 12(3); after coord. conj., 40; subord. conj., 99; modal aux., 155; past participle, 25; infinitive, 33 ; nitht, 16; sep. prefix, $50(2), 108$; verb, 37-39, 96-99.

'You', 1(2), 18.

'your', 30, 30(3).

$3 \mathrm{cr}=, \dot{4} 7(3) c$.

$3^{\mathrm{II}}$, prep., $90(2)$; prefix, 52 ; with infin. 87,152 .

$3^{\mathfrak{w i} \text { ifdec }}, 92$. 
' 
Prärens

imperfektum

pirfektum

reusguamperfektum

7 uturum

7 sturum exactum

entyahl

meityahl.

manalich

muiblich

sächlich.

91 
